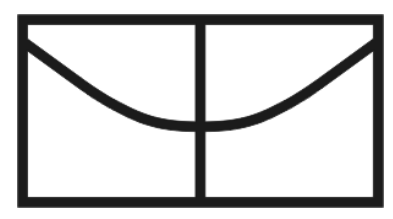

Universidade de Brasília

Instituto de Psicologia

Departamento de Processos Psicológicos Básicos

Pós-Graduação em Ciência do Comportamento

Área de Concentração: Análise do Comportamento

\title{
ANÁLISE ECONÔMICO-COMPORTAMENTAL OPERANTE DE DECISÕES EM COLEGIADO DE UMA CORTE DE CONTAS
}

Paulo Roberto Cavalcanti

Orientador: Prof. Dr. Jorge M. Oliveira-Castro

Brasília - Fevereiro - 2017 




Universidade de Brasília

Instituto de Psicologia

Departamento de Processos Psicológicos Básicos

Pós-Graduação em Ciência do Comportamento

Área de Concentração: Análise do Comportamento

\section{ANÁLISE ECONÔMICO-COMPORTAMENTAL OPERANTE DE DECISÕES EM \\ COLEGIADO DE UMA CORTE DE CONTAS}

Paulo Roberto Cavalcanti

Orientador: Prof. Dr. Jorge M. Oliveira-Castro

Tese Apresentada ao Programa de PósGraduação em Ciência do Comportamento, Instituto de Psicologia, Área de Concentração em Análise do Comportamento, como parte dos requisitos para a conclusão do curso de Doutorado.

Brasília - Fevereiro - 2017 


\section{Comissão Examinadora}

A Banca Examinadora foi composta por:

Prof. Dr. Jorge Mendes de Oliveira-Castro (Presidente) Universidade de Brasília- UnB

Profa. Dra. Eileen Pfeiffer Flores (Membro Efetivo) Universidade de Brasília - UnB

Prof. Dr. Julio Cesar de Aguiar (Membro Efetivo)

Universidade Católica de Brasília - UCB

Prof. Dr. Lauro Eugênio Guimarães Nalini (Membro Efetivo)

Pontifícia Universidade Católica de Goiás - UCG

Prof. Dr. Márcio Borges Moreira (Membro Efetivo)

Centro Universitário de Brasília - UniCeub

Prof. Dr. Rafael Barreiros Porto (Membro Suplente)

Universidade de Brasília - UnB 


\section{Agradecimentos}

Primeiramente gostaria de agradecer a minha mãe pelo incentivo e apoio incondicional em todos os momentos durante meus estudos, você me ofereceu todo o suporte necessário para cumprir essa nova etapa da minha vida. Também gostaria de agradecer meus avós, Mabel e Ricardo Cavalcanti por serem modelos intelectuais que sempre busquei seguir.

Agradeço a minha namorada Júlia por ter sido parte crucial desse processo. Todo seu amor, incentivo e compreensão ajudaram a tornar esse projeto possível.

Agradeço a todos meus colegas de pós-graduação que tive a oportunidade de conviver ao longo desses anos. Agradeço aos colegas de grupo de pesquisa Ana Paula, Ariela, Carla Patrícia, Rogério, e especialmente a minha amiga Adriana. Todos vocês me ajudaram e contribuíram muito para a realização desse trabalho.

Agradeço à CAPES pelo essencial suporte financeiro que foi concedido ao longo de meu doutorado.

Agradeço aos professores Julio Cesar de Aguiar, Márcio Borges Moreira, Eileen Pfeiffer Flores, Lauro Eugênio Guimarães Nanini e Rafael Barreiros Porto por se disponibilizarem a banca examinadora da minha tese e por todos seus comentários e sugestões.

Por fim, gostaria de agradecer sobretudo ao meu orientador Jorge Mendes Oliveira-Castro por ter contribuído com o meu desenvolvimento enquanto pesquisador desde o mestrado e agora no doutorado. Muito obrigado pelo modelo intelectual e acadêmico que diferenciado que me proporcionou ao longo desses sete anos. Seus ensinamentos, contribuições e conduta foram essenciais para minha formação como acadêmico e como profissional. 


\section{Sumário}

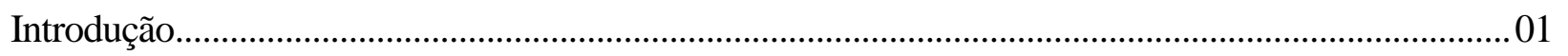

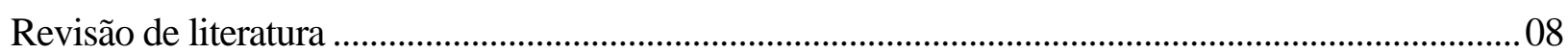

Análise econômica do direito ...................................................................................................... 08

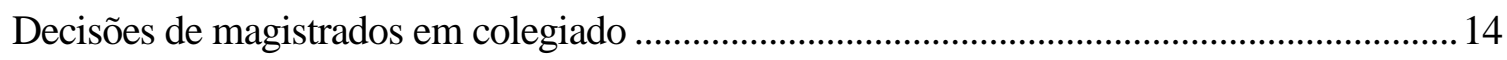

Interações entre economia e análise do comportamento. .........................................................2

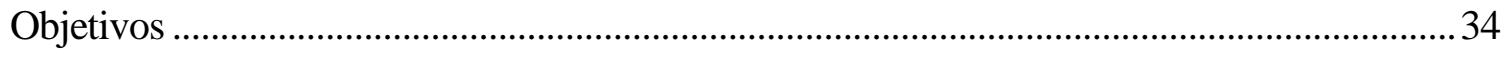

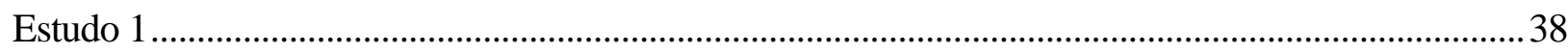

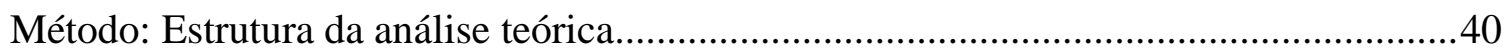

Interações entre economia e análise do comportamento. ..........................................42

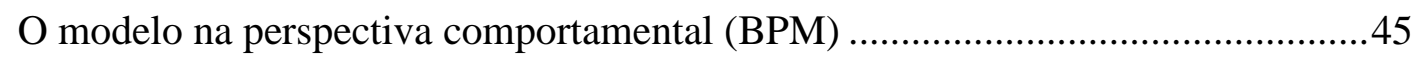

Resultados e Discussão: O modelo econômico-comportamental operante para decisões







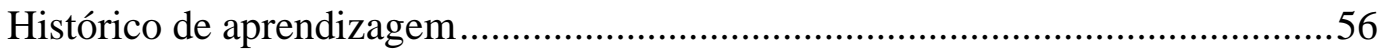

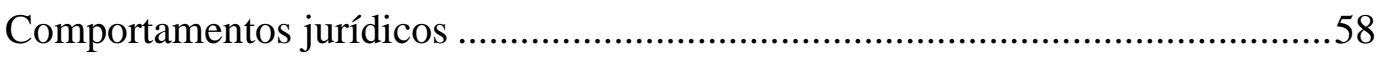

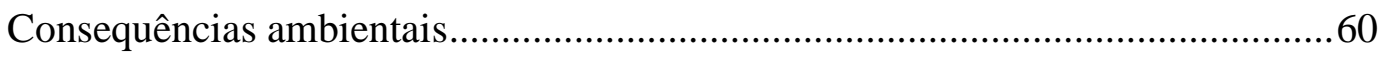

Consequências utilitárias .............................................................................62

Consequências informativas......................................................................62

Outras considerações .......................................................................................63 


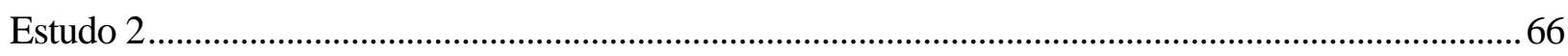

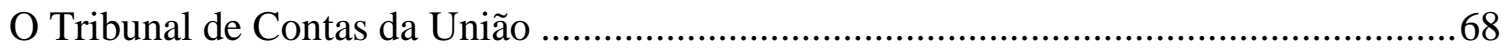

O processo de Tomada de Contas Especial ..................................................................70

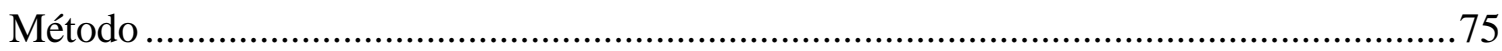

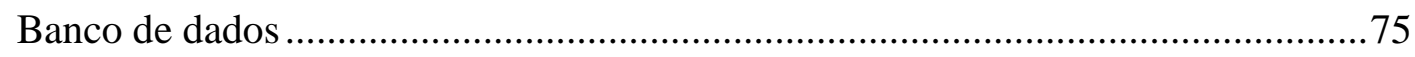

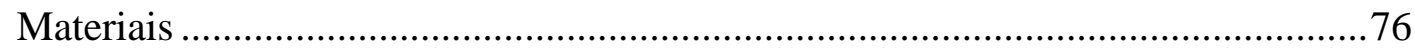

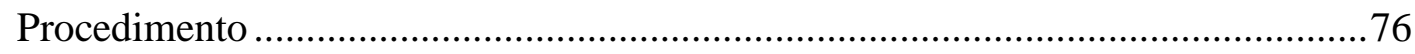

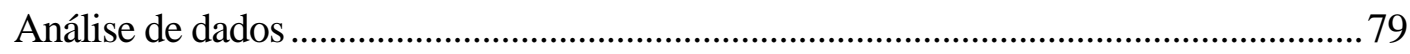

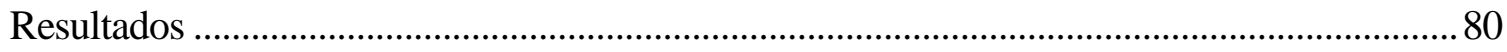

Composição dos colegiados ...................................................................................... 80

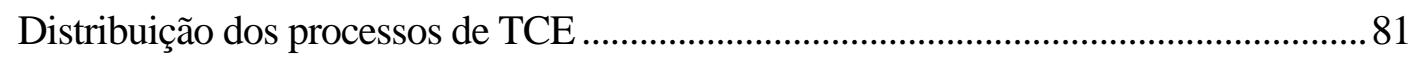

Variáveis relacionadas aos processos de TCE ............................................................... 81

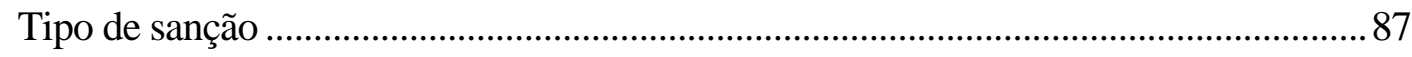

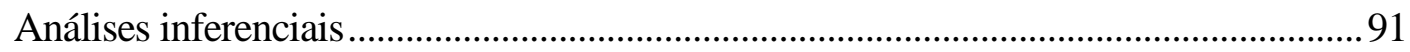

Análises de variância ........................................................................................92

Regressões múltiplas...........................................................................................99

Regressões para a variável multa 57 .............................................................98

Regressões para a variável \% multa 57 ........................................................... 102

Regressões para as variáveis multa 58 e para \% multa 58 ............................. 106

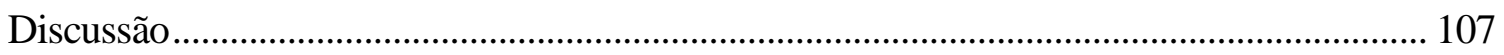

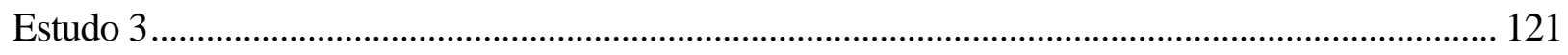

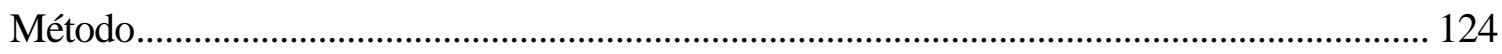

Banco de dados e materiais....................................................................... 124 
Procedimento e Análise de dados .......................................................... 125

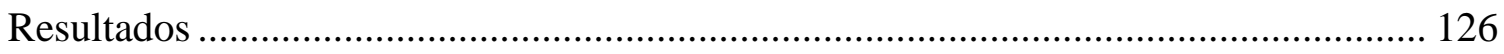

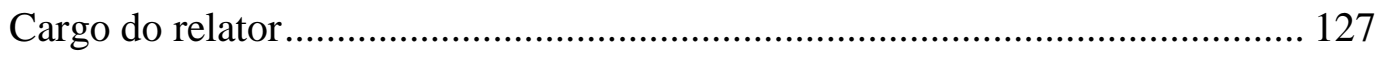

Composiç̧ão dos colegiados ...................................................................... 127

Distribuição dos processos de TCE........................................................... 127

Variáveis relacionadas aos processos de TCE.............................................. 129

Tipo de sanção...................................................................................... 133

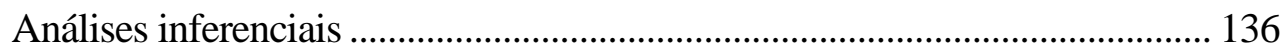

Análises de variância........................................................................... 136

Regressões múltiplas ..................................................................... 138

Regressões para a variável multa 57 ................................................ 139

Regressões para a variável \% multa 57 .......................................... 141

Regressões para as variáveis multa 58 e para \% multa 58 ............... 143

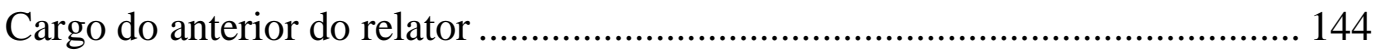

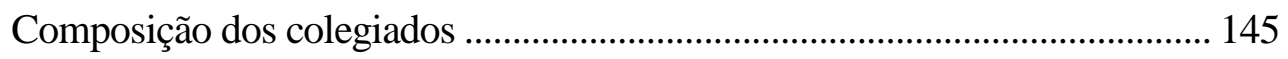

Distribuição dos processos de TCE................................................................. 145

Variáveis relacionadas aos processos de TCE.............................................. 146

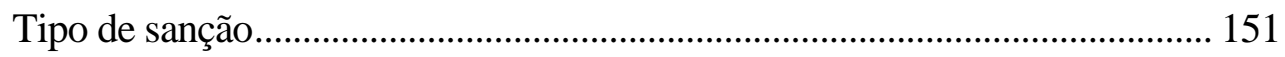

Análises inferenciais ............................................................................ 154

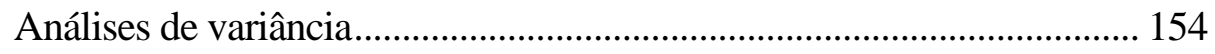

Regressões múltiplas ...................................................................... 156

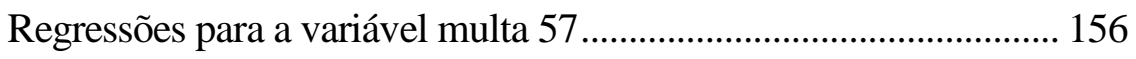

Regressões para a variável \% multa 57 ........................................... 158 
Regressões para as variáveis multa 58 e para \% multa 58 ............... 158

Comparações entre cargo do relator e cargo anterior do relator ...................... 158

Comparações individuais entre relatores................................................. 160

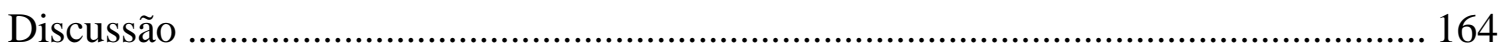

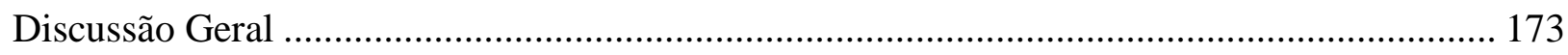

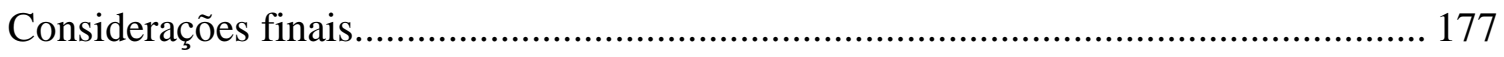

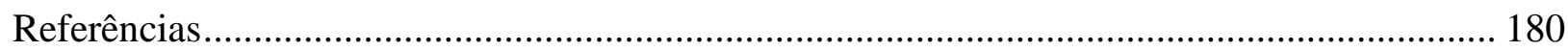

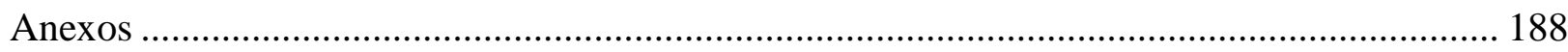




\section{Lista de Tabelas}

Tabela 1. Sumário das definições operacionais das principais variáveis investigadas nos estudos 2 e 3 .78

Tabela 2. Frequência (e porcentagem) de relatores responsáveis por acórdãos de decisão de processos de TCE tramitados em cada um dos colegiados em todas as amostras

Tabela 3. Frequência (e porcentagem) de processos de TCE tramitados em cada um dos colegiados em todas as amostras.

Tabela 4. Frequência (e porcentagem) de processos de TCE em função do cargo do gestor em todos colegiados e amostras

Tabela 5. Frequência (e porcentagem) de processos de TCE por região do Brasil da unidade federativa onde ocorreu a irregularidade em todos colegiados em todas as amostras. .84

Tabela 6. Frequência (e porcentagem) de motivos de instauração de processo de TCE por colegiado em todas as amostras .85

Tabela 7. Médias, desvio padrão e distribuição das medidas referentes a duração dos processos de TCE em anos em todos os colegiados e amostras. .86

Tabela 8. Médias, desvio padrão e distribuição das medidas referentes ao número de acórdãos emitidos nos processos de TCE em todos os colegiados e amostras .86

Tabela 9. Médias, desvio padrão e distribuição das medidas referentes ao número de processos apensados aos processos de TCE em todos os colegiados e amostras

Tabela 10. Médias, desvio padrão e distribuição das medidas referentes a multa baseada no art.

57 (multa 57) aplicada em processos de TCE em todos os colegiados e amostras .88 
Tabela 11. Médias, desvio padrão e distribuição das medidas referentes a porcentagem da multa baseada no art. 57 (\% multa 57) aplicada em processos de TCE em todos os colegiados e amostras

Tabela 12. Médias, desvio padrão e distribuição das medidas referentes a multa baseada no art. 58 (multa 58) aplicada em processos de TCE em todos os colegiados e amostras 90

Tabela 13. Médias, desvio padrão e distribuição das medidas referentes a porcentagem da multa baseada no art. 58 (\% multa 58) aplicada em processos de TCE em todos os colegiados e amostras .90

Tabela 14. Frequência (e porcentagem) de ocorrência de sanção de inabilitação nos processos de TCE em todos colegiados e amostras 91

Tabela 15. Valores aferidos para a análise de variância unidirecional (ANOVA, teste post-hoc (Tukey’s HSD) e comparação entre médias para as variáveis referentes aos processos de TCE em todos os colegiados e amostras 94

Tabela 16. Parâmetros aferidos por regressão múltipla com os preditores relacionados as características do processo para a variável multa 57 em todas as amostras para o nível de análise de colegiado .99

Tabela 17. Parâmetros aferidos por regressão múltipla com os preditores relacionados a motivo de instauração para a variável multa 57 em todas as amostras para o nível de análise de colegiado 101

Tabela 18. Parâmetros aferidos por regressão múltipla com os preditores relacionados a cargo do gestor para a variável multa 57 em todas as amostras para o nível de análise de colegiado ..... 103 
Tabela 19. Parâmetros aferidos por regressão múltipla com os preditores relacionados a características do processo para a variável \% multa 57 em todas as amostras para o nível de análise de colegiado

Tabela 20. Parâmetros aferidos por regressão múltipla com os preditores relacionados a motivo de instauração para a variável \% multa 57 em todas as amostras para o nível de análise de colegiado 105

Tabela 21. Frequência (e porcentagem) de relatores responsáveis por acórdãos de decisão em processos de TCE em função do cargo do relator em todos colegiados e amostras ..... 127

Tabela 22. Frequência (e porcentagem) de acórdãos de decisão emitidos em processos de TCE em função do cargo de ocupado pelo relator em todos colegiados e amostras.

Tabela 23. Frequência (e porcentagem) de processos de TCE em função do cargo de ocupado pelo gestor ou responsável por fundos públicos em função do cargo ocupado pelo relator em todas as amostras.

Tabela 24. Frequência (e porcentagem) de processos de TCE por região do Brasil da unidade federativa onde ocorreu a irregularidade em função do cargo do relator em todas as amostras 130 Tabela 25.Frequência e porcentagem de motivos de instauração de processo de TCE em função do relator em todas as amostras

Tabela 26. Médias, desvio padrão e distribuição das medidas referentes a duração dos processos de TCE em anos em função do cargo do relator em todas as amostras 132 Tabela 27. Médias, desvio padrão e distribuição das medidas referentes ao número de acórdãos emitidos nos processos de TCE em função do cargo do relator em todas as amostras 132 Tabela 28. Médias, desvio padrão e distribuição das medidas referentes ao número de processos apensados aos processos de TCE em função do cargo do relator em todas as amostras 133 
Tabela 29. Médias, desvio padrão e distribuição das medidas referentes a multa baseada no art. 57 (multa 57) aplicada em processos de TCE em função do cargo do relator em todas as amostras 134

Tabela 30. Médias, desvio padrão e distribuição das medidas referentes a porcentagem da multa baseada no art. 57 (\% multa 57) aplicada em processos de TCE em função do cargo do relator em todas as amostras. 134

Tabela 31. Médias, desvio padrão e distribuição das medidas referentes a multa baseada no art. 58 (multa 58) aplicada em processos de TCE em função do cargo do relator em todas as amostras 135

Tabela 32. Médias, desvio padrão e distribuição das medidas referentes a porcentagem da multa baseada no art. 58 aplicada em processos de TCE em função do cargo do relator em todas as amostras 135

Tabela 33. Frequência (e porcentagem) de ocorrência de sanção de inabilitação nos processos de TCE em função do cargo do relator em todas as amostras 136

Tabela 34. Parâmetros aferidos por regressão múltipla com os preditores relacionados a características do processo para a variável multa 57 em todas as amostras para o nível de análise cargo do relator

Tabela 35. Parâmetros aferidos por regressão múltipla com os preditores relacionados ao motivo de instauração para a variável multa 57 em todas as amostras para o nível de análise cargo do relator 140

Tabela 36. Parâmetros aferidos por regressão múltipla com os preditores relacionados a cargo do gestor para a variável multa 57 em todas as amostras para o nível de análise cargo do colegiado 
Tabela 37. Parâmetros aferidos por regressão múltipla com os preditores relacionados a características do processo para a variável \% multa 57 em todas as amostras para o nível de análise cargo do relator

Tabela 38. Parâmetros aferidos por regressão múltipla com os preditores relacionados ao motivo de instauração para a variável \% multa 57 em todas as amostras para o nível de análise cargo do relator 144

Tabela 40. Frequência (e porcentagem) de acórdãos de decisão emitidos em processos de TCE em função do tipo de cargo ocupado anteriormente pelo relator em todos colegiados e amostras 146

Tabela 41. Frequência (e porcentagem) de processos de TCE em função do cargo de ocupado pelo gestor ou responsável por fundos públicos em função do tipo de cargo ocupado anteriormente pelo relator em todos colegiados e amostras 147

Tabela 42. Frequência (e porcentagem) de processos de TCE por região do Brasil da unidade federativa onde ocorreu a irregularidade em função do tipo de cargo ocupado anteriormente pelo relator em todas as amostras 148

Tabela 43. Frequência (e porcentagem) de motivos de instauração de processo de TCE em função do tipo de cargo ocupado anteriormente pelo relator em todas as amostras .....

Tabela 44. Médias, desvio padrão e distribuição das medidas referentes a duração dos processos de TCE em anos em função do tipo de cargo anterior do relator em todas as amostras 150 Tabela 45. Médias, desvio padrão e distribuição das medidas referentes ao número de acórdãos emitidos em processos de TCE em função do tipo de cargo anterior do relator em todas as amostras 150 
Tabela 46. Médias, desvio padrão e distribuição das medidas referentes ao número de processos apensados em processos de TCE em função do tipo de cargo anterior do relator em todas as amostras

Tabela 47. Média, frequência, desvio padrão e distribuição das medidas referentes a multa baseada no art. 57 (multa 57) aplicada em processos de TCE em função do tipo de cargo anterior do relator em todas as amostras 152

Tabela 48. Média, frequência, desvio padrão e distribuição das medidas referentes a porcentagem da multa baseada no art. 57 (\% multa 57) aplicada em processos de TCE em função do tipo de cargo anterior do relator em todas as amostras 152

Tabela 49. Médias, frequência, desvio padrão e distribuição das medidas referentes a multa baseada no art. 58 (multa 58) aplicada em processos de TCE em função do tipo de cargo anterior do relator em todas as amostras 153

Tabela 50. Médias, frequência, desvio padrão e distribuição das medidas referentes a porcentagem da multa baseada no art. 58 (\% multa 58) aplicada em processos de TCE em função do tipo de cargo anterior do relator em todas as amostras 153

Tabela 51. Frequência (e porcentagem) de ocorrência de sanção de inabilitação nos processos de TCE em função do tipo de cargo ocupado anteriormente pelo relator em todas as amostras ... 154 Tabela 52. Parâmetros aferidos por regressão múltipla com os preditores relacionados a características do processo para a variável multa 57 em todas as amostras para o nível de análise cargo anterior do relator 157

Tabela 53. Frequência (e porcentagem) de processos de TCE por amostra para cada relator que atingiu os critérios de inclusão para as análises de comparativas. 
Tabela 54. Valores aferidos para a análise de variância unidirecional (ANOVA, teste post-hoc (Tukey's HSD) e comparação entre médias para as variáveis referentes aos processos de TCE

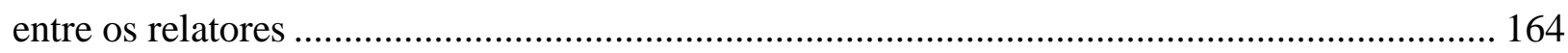




\section{Lista de Figuras}

Figura 1. Esquema do Modelo na Perspectiva Comportamental - BPM. Adaptado de Foxall, (2010). .46

Figura 2. Modelo econômico-comportamental operante para decisões em colegiado. O modelo é baseado contingência tríplice proposta pelo BPM (Foxall, 2010). 53

Figura 3. Esquema representativo dos três tipos de regressões múltiplas conduzidas para o nível de análise de colegiado. Em todas as regressões foram empregados as variáveis A e um dos grupos de variáveis $\mathrm{B}$ como preditores (1, 2 ou 3) para cada uma das quatros variáveis dependentes $(\mathrm{C})$. .98

Figura 4. Esquema representativo dos três tipos de regressões múltiplas conduzidas para o nível de análise cargo do relator. Em todas as regressões foram empregados a variável A e um dos grupos de variáveis B como preditores (1, 2 ou 3) para cada uma das quatros variáveis dependentes (C). 138

Figura 5. Esquema representativo dos três tipos de regressões múltiplas conduzidas para o nível de análise tipo de cargo anterior do relator. Em todas as regressões foram empregados a variável A e um dos grupos de variáveis B como preditores (1, 2 ou 3) para cada uma das quatros variáveis dependentes $(\mathrm{C})$. 156 


\section{Resumo}

O estudo de decisões de magistrados em colegiado representa um importante campo de pesquisa teórica e empírica, pois as decisões emitidas por tribunais jurídicos e de contas afetam de modo significativo a sociedade. Apesar de estudos empíricos se referirem a decisões em cortes jurídicas, existe uma escassez de estudos acerca desse fenômeno em cortes de contas. Enquanto corte de contas, uma das principais atribuições do Tribunal de Contas da união (TCU), se refere a condução de processos de tomada de contas especial (TCE). Esses processos são instaurados uma vez que seja identificado dano ao erário por gestores de recursos públicos, e seu principal objetivo é apurar responsabilidade e ressarcir o valor do dano. Com o intuito de investigar empiricamente decisões em colegiado em processos de TCE, e a partir disso prover explicações teóricas acerca desse fenômeno, o presente trabalho conduziu três estudos. O Estudo 1 teve cunho teórico, e o objetivo foi propor um modelo econômico-comportamental operante para decisões em colegiado. $\mathrm{O}$ modelo proposto se baseou no modelo na perspectiva comportamental (BPM), que consiste em uma adaptação do modelo operante com a integração de elementos de economia comportamental. A partir disso apresentou-se um modelo caracterizado pela integração entre elementos provenientes da análise econômica do direito e da análise comportamental do direito visando complementaridade teórica e metodológica para o estudo de decisões de magistrados em colegiado. A partir do modelo teórico aqui desenvolvido, o Estudo 2 investigou se as sanções propostas por relatores de processos de TCE são influenciadas pelas características do processo e sobretudo pelo colegiado onde esse foi tramitado (i.e., cenário de decisão). Para alcançar tal objetivo, foram analisados os acórdãos sobre processos de TCE referentes a um banco de dados contendo 742 casos. A partir de análises descritivas e inferenciais, os resultados indicaram que variáveis que medem as sanções e as características do processo apresentam diferenças significantes entre as Câmaras e o Plenário. Também se verificou que as sanções propostas pelos relatores sofrem influência do colegiado, de modo que os processos com sanções mais severas tramitaram no Plenário. Por fim, o Estudo 3 investigou diferenças individuais nas sanções propostas pelos relatores. A partir disso, foi investigado se tais sanções são influenciadas pelo cargo ou cargo anterior dos relatores (i.e., variáveis de histórico de aprendizagem de comportamento jurídicos). Empregando o mesmo banco de dados e metodologia do estudo empírico anterior, os resultados indicaram um pequeno efeito em função do cargo do relator, de modo que as sanções relativamente maiores foram propostas por Ministros. Também foram conduzidas comparações entre relatores, onde foram verificadas diferenças significantes entre indivíduos. Tomados em conjunto, os estudos empíricos demonstraram que variações nas decisões de Ministros e Ministros-substitutos do TCU sofrem influência de variáveis ambientais e individuais, não podendo ser explicadas exclusivamente em termos normativo. Por fim, o presente estudo também demonstrou como os comportamentos jurídicos de relatores em colegiado de uma corte de contas pode ser investigado empiricamente a partir de uma perspectiva econômico-comportamental operante, e demonstrou que tal arcabouço representa uma alternativa teórica e metodológica viável para esse campo de estudo.

Palavras-chave: Análise econômica do direito, análise comportamental do direito, modelo econômico-comportamental operante para decisões em colegiado, tomada de contas especial, decisões de magistrados em colegiado. 


\begin{abstract}
The study of panel effects in collegiate court decisions constitutes a relevant field of research, as decisions issued by courts of justice and courts of accounts often have significant effects in society. Despite the focus of many empirical studies on decision-making in judicial courts, few to studies investigated this phenomenon regarding courts of accounts. As the most important Brazilian court of accounts, the Federal Court of Accounts (Tribunal de Contas da União -TCU) have as one of his primary functions to conduct special provision of accounts (tomada de contas especial -TCE). Those processes are instated in the event of irregularities rendered by public officials who manage federal resources, and serve the main purpose of identifying those responsible for the irregularities, and to quantify and retrieve the financial damages. To empirically investigate and provide theoretical explanations about collegiate court decisions regarding special provisions of accounts, the present research conducted three studies. The Study 1 was theoretical and presented an operant behavioral economic model for panel decisions. This model was based on the behavioral perspective model (BPM), which consists of an adaptation of the operant framework in which conceptual elements from behavioral economics are included. Based on this framework, the proposed model integrated concepts from economic analysis of law and behavioral analysis of law that provided a theoretical and methodological complementarity for the study of collegiate court decisions at the TCU. Using the theoretical model proposed in the previous study, Study 2 investigated if the collegiate in which the proceedings took place (i.e., behavioral setting) and procedural variables influence the sanctions that appointed rapporteurs (i.e., reporting Ministers and Surrogate-Ministers) proposed for TCE cases. In order to achieve this objective, descriptive and inferential analyses were conducted using a database containing information regarding the decisions of 742 cases of TCE. The results indicated that significant differences in measures related to procedural variables and sanctions of TCE cases are related to the collegiate in which the case were processed. It was also found that the collegiate were the case were processed influence the characteristics of the sanctions, so that the Full Court produced the harshest penalties. Lastly, Study 3 explored individual differences in sanctions of TCE cases. More precisely, such sanctions were investigated to verify if they are influenced by the previous position or by the current position of the rapporteurs (variables conceptualized as judicial behavior learning history). Using the same database and methodology from the previous empirical study, the results indicated a small effect related to the current position of the appointed rapporteur of the case, and it was verified that the Ministers attributed slightly more severe sanctions. Comparisons between appointed rapporteurs were also conducted, and differences in sanctions at individual level were also identified. Taken together, the empirical studies demonstrated that variations in the decisions proposed by Ministers and Surrogate-Ministers of the TCU suffer influence from contextual, procedural and individual variables, so that normative oriented models cannot fully explain decision-making behavior of those officials in TCE cases. Lastly, the present research have shown how is possible to investigate collegiate court decisions under an operant behavioral economic model perspective, and demonstrated that this framework constitutes a viable theoretical and methodological alternative for this field of study.
\end{abstract}

Keywords: Economic analysis of law, behavioral analysis of law, operant behavioral economic model for panel decisions, special provisions of accounts, collegiate court decisions. 
O Tribunal de Contas da União (TCU) é um tribunal administrativo e se caracteriza como uma corte de contas, e tem como tarefa primária a fiscalização e o julgamento de contas de administradores públicos quanto ao uso de recursos e patrimônios públicos federais. O Tribunal é composto por nove ministros e quatro ministros-substitutos, que compõem os colegiados no âmbito dos quais os julgamentos e decisões ocorrem. A suas deliberações podem ocorrer em duas câmaras, compostas por quatro ministros, ou no Plenário, sua instância máxima, composta por todos os ministros e o presidente do TCU. No que diz respeito a sua natureza jurídica, ele é autônomo e independente. (Tribunal de Contas da União [TCU], 2002, 2015)

São atribuições do TCU: aplicar sanções aos gestores que deram causa a danos ao erário ou cometeram ilegalidades na aplicação dos recursos, determinar prazos para a adoção das providências solicitadas, fiscalizar processos de licitação e contratos, dentre várias outras atribuições elencadas no art. 71 da Constituição Federal de 1988 (TCU, 2015). Uma das principais atividades do TCU se refere aos processos de Tomada de Contas Especial (TCE), que foi investigado no presente trabalho. O processo de TCE tem como função julgar contas dos gestores ou responsáveis por recursos públicos federais, e conforme estabelecido pelo art. 71, inciso II, da Constituição Federal de 1988 (TCU, 2015), é instaurado no caso de se constatar algum tipo de prejuízo ao patrimônio público, desvio de verba, ou uso irregular de recursos (i.e., dano ao erário). O processo de TCE tem como objetivo apurar os fatos, identificar os responsáveis e quantificar o valor do dano ao erário, para que ele seja restituído de modo mais imediato possível (Controladoria-Geral da União [CGU], 2013; TCU, 2002, 2015).

Apesar de ser um tribunal de contas com natureza predominantemente administrativa, o TCU possui diversas características semelhantes às de um tribunal judicial, no que tange à sua composição, ritos, normativos internos, e natureza dos julgamentos. Essas semelhanças são ainda 
mais acentuadas ao se comparar a estrutura de carreira e as atribuições profissionais de um juiz de colegiado com as dos ministros do TCU, tendo em vista que os ministros do TCU terão as mesmas garantias, prerrogativas, impedimentos, vencimentos e vantagens dos Ministros do Superior Tribunal de Justiça (cf. art. 73, § 3º, da Constituição Feral de 1988, TCU, 2015).

Tanto as decisões emitidas pelo TCU quanto as decisões judiciais emitidas pelos diversos tribunais brasileiros, podem afetar a população significativamente, pois possuem potencial para produzir grande impacto social, político e econômico. Apesar da relevância e do impacto social dessas instituições, os estudos científicos de natureza empírica sobre as práticas jurídicas de modo geral, e sobretudo acerca de decisões judiciais e das decisões tomadas nas cortes de contas são relativamente escassos, principalmente no Brasil. Nesse sentido, o direito enquanto área do conhecimento e disciplina acadêmica aplicada não possui a tradição de investigar e nem amparar as práticas do judiciário e dos operadores da lei a partir de resultados de estudos científicos baseados em dados empíricos.

De acordo com Gico (2010), o direito não oferece ferramentas teóricas e nem metodológicas para realizar investigações dessa natureza. No entanto, diversos trabalhos teóricos e empíricos têm sido conduzidos na área de análise econômica do direito na busca de explicações amparadas empiricamente para os mais variados fenômenos e temas de discussão que fazem parte as práticas jurídicas (e.g., Cooter \& Ulen, 2007; Epstein, Landes \& Posner, 2011, 2013; Posner, 1995, 2007). Essa área de estudo se caracteriza pela utilização de princípios teóricos e ferramentas metodológicas provenientes da economia, sobretudo microeconomia, para a investigação objetiva e empírica de tais fenômenos.

Um dos temas mais discutidos neste tipo de literatura se refere às decisões de juízes em colegiado. Essas decisões são tomadas em colegiados compostos por três ou mais juízes, e 
geralmente envolvem o julgamento de recursos legais vindos de instâncias inferiores da justiça, mas também podem se referir a decisões em primeira instância (cf. Epstein, et al., 2011, 2013; Posner, 1995, 2007). Tipicamente em processos que transcorrem em colegiado, existe um juiz que ocupa a função de relator. Cabe ao relator analisar o caso e emitir uma sentença ou sanção, sendo que esta é justificada a partir de uma análise fundamentada em parâmetros jurídicos e normativos. A partir da apresentação da sentença, os demais membros do colegiado emitem um voto, que pode ser contra ou a favor da decisão do relator (cf. Washington, 2001) e desse modo a partir da verificação da maioria dos votos, aceita-se ou rejeita-se tal decisão.

Para Posner (1995, 2007), os juízes são pessoas ordinárias, e, portanto, os seus comportamentos podem ser objeto de análise e previsão a partir de uma análise econômica assim como os comportamentos de escolha e decisão de qualquer outra pessoa em outros contextos. O autor também afirma que como não existe punição e nem incentivos específicos pela posição jurídica assumida em um voto, os juízes de colegiado apresentam uma preferência pela resposta de menor custo (i.e., mais típica ou mais presente na jurisprudência). A partir dessas premissas e considerando que o voto dissidente gera uma maior carga de trabalho para o juiz e seus pares, existiria uma tendência e uma maior prevalência em se votar com a maioria, que geralmente significa acompanhar o voto do relator do processo. Pesquisas empíricas têm corroborado esse tipo de predição, e também identificaram que diversos fatores podem exercer influência nesse processo de decisão, tais como: o tamanho do colegiado, o posicionamento ideológico e político dos membros do colegiado e a carga de trabalho de um tribunal (cf. Epstein et al., 2011, 2013; Kim, 2009; Lauderdale \& Clark, 2012; Sisk \& Heise, 2005).

Ainda no que se refere a estudos científicos de fenômenos relacionados ao direito, de acordo com Oliveira-Castro (2011), tanto a abordagem econômica quanto a operante têm 
produzido investigações sobre o tema. O autor também destaca que a despeito do volume de trabalhos baseados em uma perspectiva econômica ser muito mais abrangente, os trabalhos baseados no paradigma analítico-comportamental também podem contribuir para o desenvolvimento da área, na medida em que demonstram grande potencial explicativo e se fundamentam em longa história de pesquisas experimentais sobre comportamento em geral. Nesse sentido, Oliveira-Castro também destaca que apesar de servir de arcabouço teórico para as mais variadas linhas de pesquisa que estudam fenômenos sociais complexos, a análise do comportamento ainda não apresentou um grande número de contribuições na investigação de fenômenos desta natureza.

Apesar de uma produção acadêmica relativamente menor, é possível constatar um dos exemplos de contribuições do paradigma analítico-comportamental para o estudo de comportamentos jurídicos em Todorov (2005), onde se examinou o estatuto da criança e do adolescente com o uso de conceitos como os de contingência tríplice e de metacontingência. O autor demonstra relevantes análises e interpretações do sistema legal a partir de um paradigma operante, e dentre outras conclusões, verifica que as leis desse estatuto foram formuladas de modo bastante assistemático, o que pode repercutir em um controle social pouco eficiente. Também é possível encontrar em Skinner (1953) discussões sobre as funções das leis e de seus efeitos sobre a sociedade e comportamento humano, onde o autor destaca que essas tem o papel primário de exercer controle sobre o comportamento dos indivíduos a partir do estabelecimento de contingências de controle.

Uma das abordagens mais dedicadas a investigação de fenômenos jurídicos com base em princípios da análise do comportamento é a análise comportamental do direito (cf. Aguiar, 2006, 2013, 2014). Essa proposta tem o intuito de tornar o direito uma ciência comportamental 
aplicada, capaz de implementar mudanças e controle social de modo mais eficiente na medida em que aumenta a frequência de comportamentos socialmente desejáveis e reduz aqueles que não são benéficos a um bem estar social comum. De acordo com Aguiar, uma das principais formas do direito intervir na sociedade é a partir das leis, que são implementadas com a atuação de diversas agências de controle, tais como os tribunais, a polícia e as instituições legislativas. Portanto, a partir disso, é necessário interpretar e implementar as leis a partir de conceitos analítico-comportamentais na medida em que essas estabelecem contingências de reforçamento (i.e., contingência jurídica) para controlar o comportamento. Ou seja, com base em princípios da análise do comportamento, é possível identificar com mais precisão a função das variáveis envolvidas nas situações e comportamentos aos quais determinada lei se destina, e com isso, seria possível planejar intervenções sociais mais eficazes, na medida em que se emprega tais parâmetros.

Nesse sentido, de acordo com Oliveira-Castro (2015), a análise comportamental do direito oferece complementaridade à produção acadêmica da análise econômica do direito. A análise econômica do direito possui uma literatura rica, e identificou uma série de regularidades acerca de comportamentos relacionados ao direito. No entanto, a proposta da análise comportamental do direito pode ajudar na interpretação das relações funcionais entre as leis e o comportamento das pessoas, entendendo que sempre existem os destinatários da lei e seus operadores, de modo que as leis possuem função distinta para cada um deles.

Também vale a pena destacar que a análise comportamental do direito também se propõe a identificar se existem diferenças entre as contingências descritas pelas leis daquelas que realmente ocorrem no mundo ou no contexto da decisão judicial. Nesse sentido, o tipo de análise funcional amparada em pesquisas empíricas que faz parte dessa proposta pode contribuir de 
modo significativo na identificação de tais contingências. Esse tipo de análise é relevante, pois as variáveis do contexto real onde ocorre o comportamento ou decisão judicial podem ser altamente relevantes como determinantes na ocorrência dos comportamentos de operadores e destinatários da lei.

Analisando o potencial das contribuições particulares oferecidas por essas duas abordagens, é possível assumir que ambas são úteis para buscar explicações e predições para os comportamentos de decisão de operadores da lei em colegiado. Partindo disso, um dos objetivos do presente trabalho (Estudo 1) foi de desenvolver um modelo teórico e metodológico que integre elementos da análise do comportamento, o que inclui a análise comportamental do direito, e a análise econômica do direito para investigar empiricamente decisões em colegiado de ministros do TCU. Desse modo, para alcançar esse objetivo, foram discutidos pontos de sobreposição e complementaridade entre tais abordagens onde se evidenciou as vantagens de uma proposta teórico-metodológica que integre elementos dessas duas linhas de pesquisa.

Para o desenvolvimento de uma proposta econômico-comportamental operante para o estudo de decisões de magistrados em colegiado será empregado como base o Modelo na Perspectiva Comportamental ou Behavioral Perpective Model (BPM) (Foxall, 2010). Esse modelo se caracteriza como um exemplo bem sucedido de integração de metodologias e conceitos provenientes da economia e análise do comportamento para estudar o comportamento de consumidores, porém, esse modelo também tem sido estendido com sucesso o contexto de comportamentos jurídicos (cf. Pinheiro \& Oliveira-Castro, 2015). O BPM apresenta algumas adaptações e inovações conceituais que podem ajudar a caracterizar de modo mais preciso as consequências ambientais que podem estar relacionadas as contingências de escolha que serão estudadas no presente trabalho. 
A partir dos parâmetro delimitados pelo modelo teórico econômico-comportamental operante (Estudo 1), dois estudos empíricos foram realizados para investigar regularidades em decisões de colegiado de ministros do TCU (Estudos 2 e 3). O Estudo 2 teve o objetivo de investigar as decisões em colegiado em processos de Tomada de Contas Especial (TCE) no TCU. Diferindo de estudos tradicionais de análise econômica do direito que investigam decisões do colegiado a partir de uma análise de grupo, no presente estudo foram analisadas as decisões do relator do processo, e como essas podem variar em função do colegiado onde o processo de TCE foi tramitado (e.g., $1^{\text {a }}$ Câmara vs. Plenário). Os relatores dos processos podem ser Ministros ou Ministros-substitutos, enquanto suas decisões no contexto do presente estudo foram as sanções propostas em acórdão para ser votada em colegiado para os gestores que cometeram dano ao erário (e.g., multa, inabilitação).

Além de investigar o colegiado onde ocorreu a decisão como uma variável independente relacionada a diferenças em sanções estabelecidas pelos relatores dos processos, também foram investigadas a influência de outras variáveis. De modo semelhante a estudos de análise econômica do direito, mas empregando uma interpretação estabelecida no Estudo 1, essas variáveis se relacionam a características do processo e do contexto da decisão em colegiado, tais como: o valor do dano ao erário, o cargo ocupado pelo gestor de recursos públicos que cometeu a infração e o tipo específico de infração (e.g., desvio, desfalque, omissão).

Enquanto o Estudo 2 analisou as decisões de relatores a nível de colegiado, o Estudo 3 investigou se variáveis relacionadas a histórico de aprendizagem de comportamentos jurídicos estão relacionadas a diferenças nas decisões dos relatores em processos de TCE. Baseando-se no modelo teórico proposto no Estudo 1, as variáveis relacionadas a histórico de aprendizagem de comportamentos jurídicos foram o cargo atual do relator e o cargo ocupado pelo relator antes de 
ser nomeado como Ministro ou Ministro-substituto do TCU. Por fim, no Estudo 3 também foi investigado se existem diferenças a nível individual nas sanções estabelecidas pelos relatores. Desse modo, ao se investigar tais regularidades, foi possível identificar com mais clareza os padrões de decisões e diferenças individuais entre os relatores de processos de TCE do TCU em função de variáveis contextuais, características relativas ao processo e sobretudo de seu histórico de aprendizagem de comportamentos jurídicos.

\section{Revisão de literatura}

\section{Análise econômica do direito}

Uma das áreas que mais tem contribuído para a produção de conhecimento empírico baseado em método científico acerca de fenômenos relacionados ao direito é a análise econômica do direito (cf. Alvarez, 2006; Gico, 2010; Epstein Landes \& Posner, 2013; Posner, 1975, 1979, 1995, 2007). Essa abordagem, assim como o campo de pesquisa referido como economia e direito (traduzido do inglês law and economics) (Cooter \& Ulen, 2007; Harney \& Marciano, 2009a), se caracteriza como uma proposta que emprega as ferramentas metodológicas e arcabouço teórico da economia para investigar os mais variados fenômenos relevantes ao direito e as atividades profissionais do sistema judiciário. Dentre os estudos realizados nessa área é possível mencionar diversos tópicos de interesse, tais como: a eficiência das leis (e.g., Cooter, 2000; Cooter \& Rubinfeld; 1989; Harney \& Marciano, 2009b), a corrupção no judiciário (Aidt, 2003; Alencar \& Gico, 2010), e os a fatores que podem influenciar as decisões de magistrados em colegiado (e.g., Epstein et al., 2011, 2013), Tais análises geralmente empregam bancos de dados relativos a decisões judiciais, e buscam realizar análises objetivas amparadas por um método sistemático baseado em princípios de microeconomia e economia comportamental. Nesse sentido, a análise econômica do direito se enquadra tanto como um campo de pesquisa 
quanto de aplicação, já que os resultados de estudos empíricos realizados nessa área podem vir a produzir impactos positivos na sociedade no que concerne ao desenvolvimento de práticas jurídicas mais eficientes (Gico, 2010).

Tais aspectos estão congruentes com o que Posner $(1995,2007)$ destaca como sendo a proposta normativa e a positiva para a análise econômica do direito. Enquanto o caráter normativo se refere a modificação e criação de leis baseadas em eficiência que sejam empiricamente comprovadas, o caráter positivo se refere a uma tentativa de explicar as práticas jurídicas e a legislação vigente. Ou seja, se destaca justamente a exploração, investigação e esclarecimento acerca de fenômenos relacionados ao direito e comportamentos jurídicos e a possibilidade de fundamentar a pratica profissional do judiciário por tais resultados.

Alvarez (2006) salienta que a análise econômica do direito estabelece um contraponto à noção de que o direito deve assumir uma postura autônoma das ciências sociais, e defende que deve empregar as ideias e metodologias de outras áreas de conhecimento, tais como a economia e as ciências políticas para melhor compreender os fenômenos relacionados às práticas jurídicas. Desse modo, ao propor uma intervenção interdisciplinar, análise econômica do direito rejeita noções tradicionais do direito sobre a realidade jurídica. Esse tipo de proposta tradicional sobre o direito tende a enfatizar a influência da lei e da norma sobre o comportamento dos Magistrados (e.g., Bobbio, 2004), em que suas explicações são amplamente amparadas por discussões filosóficas e ideológicas, em detrimento de explicações baseadas em pesquisas empíricas. Portanto, ao buscar embasamento teórico e metodológico em uma ciência social estabelecida tal como a economia, o produto final da análise econômica do direito busca produzir práticas e intervenções mais consistentes, e no desenvolvimento de um conhecimento mais claro da realidade que cerca o sistema judiciário. 
Ainda no que se refere às concepções teóricas tradicionais sobre o direito, Gico (2010) destaca que ao longo da história da disciplina existiram diversos movimentos ou paradigmas, que foram desenvolvidos com o intuito de buscar explicações e de fundamentar a prática jurídica a partir de critérios que pudessem resultar em um direito mais uniforme e que melhor alcançasse resultados sociais. Essas diferentes linhas de pensamento, como o jusnaturalismo, o juspositivismo e o neo-constitucionalismo foram amplamente influenciados pelo pensamento filosófico, científico e pelo momento histórico no qual surgiram, de modo que o foco de suas discussões passou por temas como a racionalidade das decisões judiciais, sobre o posicionamento moral e a hierarquia de valores do direito.

Epstein et al. (2013) também discutem os movimentos ou paradigmas tradicionais do direito, ressaltando que esses também são utilizados para explicar o comportamento dos magistrados, e dentre esses movimentos, se destacam basicamente dois tipos de postura teórica. A primeira delas se chama legalismo ou formalismo, que em termos simples considera que o comportamento dos juízes ocorre quase que completamente em função da aplicação critérios estabelecidos por normativos e pela lei aos devidos casos, em uma relação quase que mecânica. Esse tipo de interpretação assume que todos os juízes possuem neutralidade em suas decisões, e em função disso, elimina a influência do contexto ou de preferências individuais sobre o comportamento dos magistrados como variáveis determinantes. Desse modo, a postura legalista ou formalista também tende a negar que interesses pessoais possam influenciar significativamente as decisões judiciais dos magistrados. Ou seja, seus votos e sanções não sofrem influência de fatores como interesses de progressão na carreia, a criação de novas jurisprudências ou o favorecimento de certo grupos políticos ou sociais. 
O segundo tipo de postura teórica é chamada de realismo tradicional ou realismo extremo, e presume que os magistrados sempre se comportam em função de motivos ou interesses particulares. Portanto, a partir dessa concepção, as decisões judiciais sempre sofrem um viés determinante de ideologias e interesses particulares, de modo que os juízes usam a lei e a estrutura do judiciário como ferramentas em prol de cumprir uma determinada agenda. Desse modo, Epstein et al. (2013) afirmam que o legalismo e o realismo representam movimentos historicamente antagonistas. Os autores também destacam que ambos movimentos apresentam limitações enquanto arcabouço teórico explicativo, e que acabaram perdendo sua relevância dentro do direito principalmente por não serem capazes de oferecer informações e resultados conclusivos empiricamente fundamentados que sustentassem suas propostas.

Ainda se referindo aos paradigmas tradicionais do direito, Gico (2010) afirma que apesar dos teóricos e operadores da lei reinventarem constantemente seus parâmetros e fundamentações acerca da prática jurídica, o direito não produziu uma teoria do comportamento e nem metodologias que permitissem analisar de forma sistemática e objetiva o impacto que esse produz na sociedade. Tanto Cooter e Ulen (2007) quanto Posner (1975, 1995, 2007) enfatizam esse argumento, e salientam que o uso da economia no direito preenche uma lacuna, pois essa oferece uma teoria comportamental para a compreensão de como as leis ou as práticas jurídicas afetam as pessoas. Além disso, a economia também permite demonstrar objetivamente a partir de seu arsenal metodológico, o quanto que certas políticas públicas ou intervenções legais são eficientes no que diz respeito a atingir certa meta social, tal como reduzir a criminalidade ou aumentar a arrecadação de impostos. Desse modo, uma prática jurídica amparada por uma ciência do comportamento, apresenta vantagens em relação a propostas baseadas em aspectos 
ideológicos ou filosóficos, pois possui ferramentas para medir objetivamente o impacto da lei em relação às metas sociais que essa visa atingir.

Nesse sentido, Posner $(1975,1995,2007)$ também destaca que o comportamento dos magistrados (i.e., decisões judiciais) são afetados por diversos fatores contextuais relativos ao processo e ao ambiente de trabalho (e.g., tribunal), além de fatores mais amplos presentes em suas vidas. Desse modo, tais fatores também devem ser investigados empiricamente, já que podem estar relacionados a padrões de decisão judicial apresentados pelos magistrado. Portanto, esse tipo de trabalho também serve para ajudar a desmistificar as práticas e funções do sistema judiciário de modo geral, na medida em essas são descritas e analisadas sistematicamente, pois o acesso ao comportamento de juízes costuma ser difícil, dado a natureza discreta ou até mesmo sigilosa de suas atividades (Epstein et al., 2013).

Possivelmente devido ao grande impacto que exercem na sociedade, um dos fenômenos mais discutidos e pesquisados nesse tipo de literatura se refere às decisões realizadas por juízes, principalmente no contexto de colegiado (e.g., Epstein et al., 2011, 2013; Kim, 2009; Lauderdale \& Clark, 2012; Posner, 1995, 2007; Sisk \& Heise, 2005). No contexto do judiciário, os colegiados representam grupos de juízes que são responsáveis por deliberar e estabelecer sentenças para diversos tipos de casos (e.g., trabalhista, eleitoral, criminal) que geralmente são relativas a recursos legais provenientes de instâncias inferiores da justiça. Dependendo da corte judicial onde as decisões são deliberadas a matéria dos casos pode ser bem específica, como por exemplo no Tribunal Superior Eleitoral (cf. TSE, 2012), que se remete a questões eleitorais. No entanto, como se verifica nos Tribunal Regionais Federais, que são instâncias intermediárias da justiça, as deliberações e decisões judiciais podem abarcar tipos de casos mais variados, tais como ações rescisórias, criminais e mandados de segurança (cf. TRF $1^{\text {a }}$ Região, 2003). Já no que 
se refere ao tamanho dos colegiados estudados na literatura de análise econômica do direito, esses costumam variar de acordo com o tipo de corte ou tribunal. Em instâncias intermediárias da justiça, os colegiados costumam ser compostos por três magistrados, enquanto que instâncias superiores de justiça possuem um número maior de membros: nove magistrados no caso da Suprema Corte dos Estados Unidos, ou até 11 ministros como se verifica no Supremo Tribunal Federal brasileiro.

Durante as deliberações em colegiado existe a figura de um relator, que costuma ser sorteado entre os magistrados que compõem uma determinada corte, e cabe ao relator a função de analisar o caso e elaborar um relatório que contém a sentença (cf. Washington, 2001). A sentença descrita no relatório também deve conter a justificativa sobre a decisão tomada pelo juiz. Tais justificativas devem ser amparadas a partir de leis e normativos jurídicos de casos precedentes que trataram de temas semelhantes, e pela doutrina, que são teses defendidas por teóricos do direito. Após essa etapa, a sentença elaborada pelo relator do processo é submetida à votação, de modo que os outros magistrados membros do colegiado poderão ou não acatá-la, votando contra ou a favor. Portanto, no contexto de colegiado, a decisão de cada juiz é o seu voto, que pode ser contra ou favor à decisão proposta pelo relator do processo, sendo que o relator sempre é considerado a favor da sentença que propôs. Desse modo, ao se analisar decisões em colegiado, geralmente não são analisadas as sentenças ou decisões no nível individual de cada magistrado, pois o que geralmente se investiga são as decisões do grupo, especificamente os votos que ocorreram no julgamento de um determinado processo.

Por fim, as informações cruciais sobre a decisão em colegiado tais como a sentença, a composição do colegiado, as deliberações do relator sobre o caso, os votos dos membros do colegiado, assim como outros aspectos procedurais (e.g., data, colegiado, magistrados presentes) 
são publicadas em um acórdão (cf. Washington, 2001). Desse modo, o acórdão representa a decisão final do colegiado sobre um determinado caso. Em função de conter as principais informações sobre os casos e as decisão em colegiado, esse documento é frequentemente empregado nas análises conduzidas em estudos baseados em análise econômica do direito.

\section{Decisões de magistrados em colegiado}

Segundo Posner (1995, 2007), os juízes são pessoas como outras quaisquer, e por isso, suas decisões judiciais são influenciadas por variáveis que afetam as decisões das pessoas em diversos outros contextos. Dentre as variáveis que influenciam as decisões das pessoas e portanto, influenciam as decisões judicias de magistrados, são salientadas as variáveis relacionadas diretamente ao contexto da decisão e aos seus desdobramentos sociais e práticos. Partindo desse princípio e se contrapondo a noções tradicionais em direito, tais como o legalismo e o realismo, o autor propõe que os comportamentos jurídicos de magistrados (i.e., decisões) podem ser objeto de investigação e previsão a partir de uma análise amparada por um arcabouço econômico. Posner também salienta que como não existem reprimendas e nem incentivos específicos pela maneira como um juiz conduz seu posicionamento em votações (i.e., votar contra ou favor) e nem quanto ao volume de trabalho que esses assumem, os juízes em contexto de colegiado tendem a priorizar práticas que envolvam um menor esforço ou dispêndio de tempo. Baseando-se nesses princípios, é possível prever que como o voto dissidente (i.e., votar contra o relator) geralmente produz uma maior carga de trabalho tanto para o magistrado que o emite, quanto para o colegiado de maneira geral, existiria uma tendência de se votar a favor da sanção proposta pelo relator, o que muitas vezes resulta em votações com unanimidade.

Outro relevante fator enfatizado por Posner (1995, 2007), é que além de uma tendência geral de se evitar carga de trabalho relacionada a uma decisão judicial, outros fatores também 
podem influenciar o voto dos magistrados, tais como o tamanho do colegiado, a ideologia política dos membros do colegiado e o volume de trabalho de um tribunal. Posner, que é um dos pioneiros e principais autores em análise econômica do direito (cf., Alvares, 2006; Harney \& Marciano, 2009a) é um juiz federal da Corte de Apelação, que é uma instância intermediária da justiça nos Estados Unidos. Portanto, além de se amparar em um arcabouço econômico para propor seu modelo teórico, muitos de seus argumentos são originados do conhecimento prático que ele possui do cargo de juiz, já que ele exerce decisões de colegiado rotineiramente em sua atividade profissional.

Em estudos baseados em economia, especialmente naqueles de análise econômica do direito (e.g., Epstein al, 2011, 2013), uma das maneiras mais empregadas para se analisar o comportamento de escolha ou decisão é a partir do uso de uma função de utilidade. Em concepções mais tradicionais, a utilidade está associada a fatores como satisfação e prazer, ou até mesmo empregada como uma medida de felicidade relacionada a uma escolha. Devido às dificuldades conceituais decorrentes de assumir esse tipo de interpretação, as concepções mais recentes de utilidade a caracterizam como benefícios, incentivos ou como atributos e bens desejáveis decorrentes de uma escolha (cf. Mankiw, 2012; Varian, 2010). Portanto, esse conceito se refere ao fato de que as pessoas maximizam utilidade em suas escolhas, ou seja, elas buscam o máximo de benefícios possíveis diante de certas restrições, como tempo e orçamento. Desse modo, uma função de utilidade é um modelo matemático que irá indicar e descrever os principais benefícios, custos e restrições relacionados a determinadas escolhas, de modo que um comportamento de decisão ou escolha será diretamente influenciado por essas variáveis. As variáveis que compõem um função de utilidade são inferidas a partir do contexto no qual o comportamento ocorre, e essa metodologia permite verificar regularidades relacionadas a 
padrões de preferência, ou seja, é possível constatar que escolhas são mais frequentes em um dado contexto.

É possível salientar que um dos contextos mais típicos onde as funções de utilidade são empregadas para descrever regularidades e padrões de escolha e decisão são em situações de compra ou consumo. No estudo desse fenômeno os benefícios estariam associados às características do produto, enquanto que as restrições podem ser interpretadas como limites do orçamento, e os custos estariam relacionados aos preços dos produtos disponíveis (OliveiraCastro, Cavalcanti \& Foxall, 2016). Portanto, em uma situação de compra, o consumidor buscará minimizar seus custos pagando preços menores, para conseguir o melhor produto possível (i.e., utilidade), mas sempre se enquadrando em uma restrição orçamentária. No entanto, vale a pena destacar que diversos tipos de comportamento de escolha podem ser estudados a partir desse tipo de modelo, mesmo aqueles considerados complexos e de alto impacto social, tais como preconceito, investimentos pessoais em educação, crimes, e até mesmo a formação da estrutura familiar (cf. Becker, 1993).

Baseando-se nesse tipo de arcabouço teórico e metodológico, Posner (1995) sugere o uso de uma função de utilidade para investigar e descrever os fatores que influenciam o comportamento de voto de juízes em colegiado. Apesar de constituir um modelo relativamente simples, ele permite visualizar os principais custos, benefícios e restrições relacionados às decisões judiciais. Ou seja, o modelo permite direcionar o foco das análises para as variáveis que os juízes tenderiam a maximizar e evitar durante sua prática profissional, e o quanto esses fatores são determinantes em suas decisões judiciais em colegiado.

Em uma versão mais atualizada desse modelo, Epstein et al. $(2011,2013)$ apresentaram uma função de utilidade judicial que possibilita sistematizar as variáveis presentes no contexto 
de decisão em colegiado que podem influenciar os comportamentos jurídicos dos magistrados (i.e., sentença, sanção, voto). Desse modo, o modelo foi descrito a partir da seguinte formalização:

$$
U=U\left(S\left(t_{j}\right), E X T\left(t_{j}, t_{n j}\right), L\left(t_{l}\right), W, Y\left(t_{n j}\right), Z\right)
$$

Neste modelo $U$ representaria utilidade, de modo que um juiz busca maximizar a utilidade diante de uma restrição de tempo $\left(T=t_{j}+t_{n j}+t_{l}\right)$ onde $T=24$ horas. Portanto, $T$ será a soma de $t_{j}$, que são as horas dedicadas a atividades judiciais, $t_{n j}$, que é o tempo gasto com atividades profissionais não judiciais, tal como lecionar em cursos de direito ou escrever artigos, e $t_{l}$ que são as horas destinadas ao lazer ou tempo livre. $S$ representa a satisfação associada ao trabalho como juiz, e inclui fatores como um bom ambiente de trabalho ou possibilidades de promoção, e terá uma relação direta com as horas dedicadas ao trabalho judicial. O EXT se refere a fontes externas de satisfação decorrentes da profissão de juiz, como prestígio social, fama, e influência, estando positivamente relacionada as horas alocadas em atividades profissionais, tanto judiciais quanto não judiciais. Nesse modelo, $L$ representa o número de horas alocadas para atividades relacionadas a lazer ou o tempo livre. Já o $W$ representa o salário como juiz, enquanto $Y\left(t_{n j}\right)$ é a remuneração obtida por atividades profissionais não judiciais, se relacionando às horas despendidas com esse tipo de atividade. Por fim, o $Z$ representa o efeito combinado de outras variáveis, incluindo o custo em aumentar a probabilidade de promoção para um cargo ou instância judicial superior. É necessário enfatizar que apesar de oferecer um bom ponto de partida para discussões e pesquisas, a função descrita por Epstein et al. (2011, 2013) representa um modelo geral e simplificado, de modo que situações mais específicas de decisão judicial 
podem requerer adaptações ou alterações das variáveis descritas para investigação da maximização de utilidade no comportamento de magistrados (e.g., diferentes jurisprudências).

De acordo com a proposta de Posner $(1995,2007)$ e Epstein et al. $(2011,2013)$ a maior parte das variáveis descritas na função de utilidade permanece relativamente estável, de forma que o principal elemento a ser maximizado é o tempo livre. Desse modo, à medida em que se evita fatores como discussões judiciais prolongadas por adotar o posicionamento jurídico da maioria (i.e., votar com o relator), se diminui o custo da resposta de votar, e com isso, o juiz maximiza o ganho de tempo livre. Esse fenômeno é chamado de aversão à dissidência (traduzido do inglês dissent aversion), e descreve a tendência de juízes de evitar votar contra o relator do processo em função desse voto dissidente estar associado ao aumento de custos para o juiz e para o colegiado como um todo. Ou seja, essa aversão à dissidência resulta em um padrão em que os juízes simplesmente votam a favor do relator, já que essa alternativa mais conservadora resulta em um menor gasto de tempo com atividades judiciais, o que permite aos magistrados se dedicarem outras atividades, tais como lazer ou até mesmo outros empregos fora do tribunal.

De acordo com Epstein et al. (2011, 2013), essa aversão à dissidência pode ser interpretada como uma aversão ao custo ou esforço de uma maneira geral, de modo que esse é decorrente do processo de maximização, onde os indivíduos buscam o máximo de utilidade dentro das restrições impostas pelos contexto as escolha. Nesse sentido, o custo de discordar pode ser compreendido a partir de uma analogia com o preço dentro de uma estrutura de mercado, onde se observa que os indivíduos tendem a evitar produtos com preço maiores. Portanto, como discordar aumenta o tempo gasto e o esforço dispendido, o preço ou custo final da decisão judicial aumenta, o que diminui a utilidade final obtida (i.e., relação custo benefício). 
Para melhor compreender as variáveis relacionadas ao padrão de aversão a dissidência, Epstein et al. (2011) revisaram e analisaram a literatura anterior sobre esse fenômeno e discutiram os principais fatores associados a sua ocorrência. A partir disso, foi empregado um modelo econômico (ilustrado na equação 1) para investigar se tais variáveis estão relacionadas a tendência dos juízes de acompanhar o voto da maioria, ou seja, a aversão a dissidência. Dentre os fatores investigados e discutidos pelos autores é possível destacar: (1) o volume de trabalho que determinado tribunal é encarregado; (2) o tamanho do colegiado, que se relaciona a convivência com os colegas, pois o custo social de discordar em um colegiado menor pode ser mais alto; (3) a ideologia, onde se verifica a que partido político que o juiz possui ligações; (4) a composição de painel, relativo as características dos membros do colegiado; (5) efeitos de reciprocidade, que é verificado quando um juiz vota a favor de quem votou a favor de casos anteriores no qual ele foi relator; (6) custo de reputação ou prestígio, que pode ocorrer na medida em que se critica ou se discorda da opinião da maioria; e por fim, como já foi discutido anteriormente, foram analisados (7) os custos relacionados ao voto, e nesse sentido, votar contra o relator envolve dedicar mais tempo para um caso em particular aumentando o tempo e esforço investido em atividades jurídicas.

Epstein et al., (2011) também destacam alguns benefícios relacionados ao comportamento de votar contra a maioria, ou seja, as possíveis vantagens que se derivam do que a literatura qualifica como um padrão de preferência por dissidência. Dentre os principais fatores destacam-se: (1) ser citado em casos futuros no mesmo tipo de jurisprudência, na medida em que se constitui um precedente jurídico; (2) e influenciar outros juízes; (4) expressar suas próprias opiniões; e (4) ganhar algum tipo de destaque. Portanto, assim como descrito na função de utilidade descrita na equação 1, as vantagens e desvantagens relacionadas a dissidência 
interagem com um determinado contexto (e.g., tamanho ou composição do colegiado) para determinar o tipo de padrão de voto que será mais frequente.

Com intuito de investigar empiricamente a aversão à dissidência, Epstein et al. (2011) examinaram 1471 registros de casos (i.e., judicial opinions) envolvendo decisões em colegiado. 446 desses casos ocorreram na Suprema Corte americana, enquanto 1025 ocorreram em Cortes de Apelação, que pertencem uma instância judicial intermediária nos Estados Unidos. A partir dessa amostra de registros de casos, foi verificado o número de palavras em cada um deles, assim como a incidência ou não de votos dissidentes. A função de utilidade empregada para realizar a análise (cf. equação 1) enfatizou basicamente a influência de quatro variáveis na ocorrência de votos dissidentes: (1) o tamanho do colegiado; (2) a composição do colegiado; (3) a carga de trabalho imposta pela dissidência; (4) e o volume de trabalho da Corte. No que se refere ao tamanho do colegiado, a Suprema Corte possui 11 magistrados, enquanto que as Cortes de Apelação são compostas por apenas três juízes. Quanto a composição, se buscou identificar a influência de ideologias políticas conflitantes entre os relatores dos processos e os membros do colegiado. No que se refere a carga de trabalho imposta pela dissidência, o número de palavras constantes nos registros dos casos foi empregado como uma medida de esforço imposto ao colegiado em decorrência de votos dissidentes. E por fim, quanto ao volume de trabalho, isso foi medido pela quantidade de casos designados a ela, onde se verificou que para a Suprema Corte, por ser a última instância da justiça norte-americana, é consideravelmente menor do que nas Cortes de Apelação.

Os resultados indicaram que nos casos da Suprema Corte se verificou a presença de pelo menos um voto dissidente em $58 \%$ da amostra (262 casos), enquanto que nos casos da Corte de Apelação só ocorreram opiniões dissidentes em 7,8\% dos relatórios analisados (80 casos). 
Também se constatou que o número de palavras nos registros de ambas as Cortes foi significativamente maior para casos nos quais ocorreu pelo menos um voto dissidente. A partir desses dados e de outras análises os autores concluíram que a frequência de dissidência é menor quando a Corte possui um volume de trabalho maior, e que a dissidência é maior quando juízes possuem ideologias distintas e quando o colegiado é maior, pois quanto menor o colegiado, maior o impacto da dissidência sobre os colegas de trabalho (Epstein, et al. 2011).

Portanto, os dados comparados de Cortes com características distintas obtidos por Epstein et al. (2011), ilustraram que ocorrência de dissidência foi consistentemente menor em contexto com um maior volume de trabalho e custos sociais, pois resultavam em um custo ou esforço elevado (i.e., desvantagem em dissentir). Também se verificou que a dissidência foi mais frequente na presença de fatores como diferenças ideológicas entre os magistrados, o que constitui um incentivo para ocorrência desse padrão de voto. Considerando tais resultados, esse trabalho exemplifica claramente o tipo de investigação e análise que é possível ser realizada a partir de um paradigma teórico e metodológico econômico, permitindo elucidar uma série de questões acerca de decisões judiciais. Além disso, trabalhos como esse confirmam as predições genéricas estabelecidas por Posner (1995), que assume que o comportamento de juízes, tais como as suas decisões judiciais em colegiado (e.g., voto), são influenciadas por variáveis contextuais. E nesse contexto de decisão, um dos principais fatores de utilidade maximizados pelos magistrados é o tempo livre, ou seja, comportamentos que impliquem em uma diminuição do tempo dedicado a atividades judiciais serão mais prováveis.

Ainda no que se refere as investigações sobre aversão a dissidência, outros tipos de variáveis também podem apresentar uma influência significaria em sua ocorrência. Dentre os estudos empíricos apresentado em Epstein et al. (2013) vale a pena destacar um trabalho no qual 
se investigou a possível influência da idade e de um juiz ter assumido a posição de sênior na probabilidade de emitirem um voto dissidente em decisões de colegiado. Nos Estados Unidos, a posição de sênior só pode ser assumida por juízes que tenham pelo menos 65 anos de idade e que tenham servido pelo menos 15 anos em cortes federais (e.g., Cortes de Apelação). Ao assumir essa posição, esses juízes mantêm o seu salário integral, mas podem diminuir a sua carga de trabalho, podendo participar em um menor número de casos. Contudo, apesar de representar um estado de quase aposentadoria, não é incomum que juízes sênior optem por manter uma carga de trabalho quase integral à que possuíam antes.

Nesse estudo, Epstein et al. (2013) partiram do princípio que um juiz assume a posição de sênior com o principal intuito de reduzir a sua carga de trabalho, pois com isso, se reduz o tempo alocado a atividades judiciais e se maximiza o tempo livre. Além disso, também foi proposto que se os juízes sênior evitarem a emissão de votos dissidentes, a sua carga de trabalho vai se tornar ainda menor, o que aumentaria ainda mais a utilidade obtida. Baseando-se nessas hipóteses, os autores realizaram regressões empregando o mesmo banco de dados utilizados em Epstein et al. (2011) para verificar se o tipo de voto emitido pelos juízes sênior (contra ou a favor ao relator) variaram em função da posição de senioridade e da idade do juiz. Adicionalmente, também se analisou a influência de efeitos de composição do colegiado, onde foi verificada a probabilidade de voto dissidente em função de oposição ideológica entre os juízes sênior (e.g., democrata vs. republicano) e os relatores do caso.

No que se refere aos efeitos de composição do colegiado relacionados a ideologia, apesar de não terem sido estatisticamente significativos, os resultados indicaram que os juízes sênior emitiram proporcionalmente mais votos dissidentes do que quando não ocupavam a posição de sênior em suas carreiras. Já no que concerne à idade e senioridade, apesar dos dados indicarem 
um declínio em votos dissidentes em função dessas duas variáveis, esses dados não foram sistemáticos o suficiente e nem estatisticamente consistentes, sugerindo a interação e influência de outros fatores como sendo mais determinantes. Os autores atribuíram essas inconsistências nos resultados a limitações metodológicas impostas pelo banco de dados empregado (Epstein et al., 2013).

Outros autores também investigaram regularidades entre posicionamento político ou ideologias sobre os padrões de votação na Suprema Corte norte-americana seguindo modelos de análise baseados em economia. Muitos desses trabalhos privilegiam investigar padrões de preferência de voto na Suprema Corte do que em cortes de justiça intermediárias, pois essa possui um colegiado relativamente maior (nove magistrados), o que permite verificar mais variações nos votos emitidos em função de interações com diferentes fatores. Por exemplo, tanto Lauderdale e Clark (2012) quanto Sisk e Heise (2005), criticaram algumas das metodologias e medidas adotadas em estudos sobre decisão de magistrados em colegiado. Um dos principais pontos abordados, se refere a dicotomia tradicional entre dois partidos políticos (Democrata $v s$. Republicano) ou dois tipos de postura (conservador vs. liberal) como medida de ideologia. De acordo com esses autores, em muitos trabalhos dessa literatura as medidas relacionadas à ideologia assumem um caráter quase que causal, e são empregadas com o intuito de realizar previsões acerca do resultado de julgamentos e do padrão de preferência (i.e., contra ou a favor) do voto dos juízes. Com isso, apesar de não negarem a influência de ideologia em decisões judiciais, os autores chamam atenção para outros fatores que podem determinar a preferência dos magistrados no contexto de voto em colegiado. Uma das questões que foram identificadas se refere a diferenças individuais em padrões de voto, uma vez que diferentes juízes apresentaram variações em seu padrão de voto em função de diferentes tipos de casos sobre áreas distintas da 
lei, e que esses padrões também apresentaram variação ao longo do tempo. Ou seja, o voto dos juízes também é sensível a jurisprudência e pode variar ao longo do tempo, de modo que o papel causal determinante da ideologia nesse tipo de literatura deve ser relativizado em relação a outros fatores.

Nesse sentido, o estudo de Kim (2009), também investigou outros tipos de efeito de composição do colegiado sobre a votação de juízes em Cortes de Apelação americanas. Isso foi realizado ao se comparar a influência da emissão dos votos dos juízes pela posição política e ideológica de três tipos de grupos de magistrados: (1) os outros juízes que compõem o colegiado onde transcorreu a votação; (2) os juízes que compõem o circuito; ou (3) os juízes que compõem a Suprema Corte. Ou seja, foi verificado se os votos dos juízes são mais influenciados pelo posicionamento jurídico e político de seus colegas de colegiado ou de fontes externas, como o circuito e a Suprema Corte. As Cortes de Apelação são instâncias intermediarias da justiça, e são compostas por um número variado de juízes, que é chamado de circuito. Por exemplo, o segundo circuito cobre o estado de Nova Iorque e possui 13 juízes ativos, de modo que para compor um colegiado, três desses juízes são escolhidos para analisar um caso. Em algumas situações, tais como recursos ou em casos com grande relevância ou controvérsia, as decisões de colegiado podem ocorrer em banc, ou seja, com a participação de todos os juízes que compõem o circuito, e não apenas dos usuais três juízes.

Com isso, para estudar o efeito dessas variáveis, Kim (2009) propõe um modelo preditivo em que foram enfatizados dois tipos de hipóteses acerca das posturas assumidas pelos juízes em colegiado. A primeira delas se refere a uma postura deliberativa dos magistrados, em que as decisões de colegiado são produto exclusivo de deliberações e argumentações entre os três juízes que compõem o colegiado, de modo que suas ações não são influenciadas por agentes 
externos, como o circuito ou a Suprema Corte. O outro tipo de postura foi caracterizada como estratégica, e assume que basicamente os juízes buscam antecipar como o circuito ou instâncias superiores da justiça irão reagir a sua decisão judicial, e a partir disso, votam de acordo com a tendência jurídica assumida por esses elementos externos. Desse modo, um colegiado tende a minimizar a chance da decisão que deliberaram ser modificada ou anulada em função de recursos que forem submetidos a essas instâncias.

Diante disso, Kim (2009) analisou um banco de dados com decisões judiciais de casos envolvendo discriminação sexual e concluiu que para prever e explicar o comportamento desses magistrados, deve-se considerar não apenas a interação entre os membros do colegiado, mas também de todo o circuito. No entanto, apesar de representar uma possibilidade de reversão futura, verificou-se que o posicionamento da Suprema Corte não foi um fator determinante para influenciar as votações do colegiado em Cortes de Apelação. Ou seja, de modo geral, os votos dos magistrados foram mais influenciados pelo posicionamento jurídico do circuito, do que pelo posicionamento do membros do colegiado onde ocorreu a deliberação ou pela Suprema Corte.

A partir de tais resultados, o estudo concluiu que os votos de um colegiado composto por três juízes serão mais influenciados pela decisão de um relator (i.e., não emitirão voto dissidente) desde que a sanção proposta apresente consistência com as tendências de posicionamento jurídico do circuito como um todo. Portanto, elementos externos ao contexto do colegiado também podem ser determinantes nas decisões dos juízes, o que oferece suporte parcial a hipótese de que uma postura estratégica é mais adotada em detrimento de uma deliberativa. Tais resultados também se relacionam ao que autores como Posner (1995) e Epstein et al. (2013) caracterizam como aversão a reversão. Pois de acordo com esses autores, a chance de ter uma decisão revertida é um fator que os magistrados buscam minimizar ao realizar suas decisões 
jurídicas, pois ter uma decisão modificada ou anulada implicaria em um de tipo punição social, na forma de um dano a reputação desse magistrado.

Partindo da concepção que o campo de pesquisa da análise econômica do direito representa um ponto de interseção entre economia, ciências políticas e direito (cf. Alvarez, 2006), diversos outros estudos estudaram a influência de outros tipos de variáveis sobre as decisões de magistrados em colegiado. Dentre esses estudos, é possível destacar as investigações sobre as seguintes variáveis: (1) os efeitos da relevância ou controvérsia política de um caso sobre as decisões em colegiado (Miles \& Sunstein, 2006); (2) análises qualitativas sobre o quanto e em que condições as ideologias políticas de um juiz de fato influenciam decisões em colegiado, em detrimento dos tradicionais estudos que verificam apenas um efeito dicotômico dessa variável (Tamanaha, 2009); (3) a influência do sexo dos juízes que compõem o colegiado em padrões de preferência de voto (Boyd, Epstein \& Martin, 2010); (4) o efeito da hierarquia das instâncias judiciais superiores sobre o comportamento de voto em colegiado de juízes de cortes inferiores (Kastellac, 2007); (5) e como já foi discutido, estudos sobre a influência da possibilidade de reversões de decisões por instâncias superiores no voto de juízes de instâncias intermediárias da justiça (Epstein, et al., 2013). Ou seja, existe um esforço contínuo de se identificar e qualificar de que modo variáveis contextuais influenciam as decisões de magistrados em colegiado.

Ao se analisar de maneira conjunta os resultados e a proposta da análise econômica do direito, fica claro que é possível investigar de forma empírica e objetiva um fenômeno complexo e de alta relevância social, que são as decisões judiciais. Além disso, os estudos descritos no presente trabalho também demostram que as investigações baseadas em banco de dados é um instrumento metodológico válido na investigação desse tipo de fenômeno. Isso é particularmente 
relevante nesse caso, pois com exceção de simulações de decisões em colegiado em laboratório, que podem carecer de validade ecológica, é praticamente inconcebível estabelecer algum tipo de delineamento baseado em controle experimental. Portanto, por meio de análises detalhadas de registros judiciais, os estudos aqui descritos demonstram uma serie de regularidades, e apontam para diversas hipóteses que podem ser aprofundadas e mais bem exploradas. Tal objetivo pode ser alcançado a partir de um refinamento teórico-conceitual e metodológico a partir da interação com outras área de conhecimento e pesquisa, tal como a análise do comportamento.

\section{Análise comportamental do direito}

Uma das características das pesquisas em economia de maneira geral é que elas dificilmente se referem a como o repertório de comportamento do sujeito se estabeleceu, de modo que existe uma tendência a se estudar o comportamento do sujeito exclusivamente em função de variáveis presente no contexto imediato, sejam essas internas ou ambientais. Ou seja, esse tipo de estudo dificilmente aborda processos de aprendizagem propriamente ditos, tais como modelagem, modelação ou a partir de regras. Outra característica desse tipo de pesquisa, é que seus modelos teóricos e estudos empíricos tendem a se focar no comportamento do sujeito médio, o que limita a identificação e explicação de padrões mais específicos de comportamento assim como de diferenças individuais.

Tais características ou predileção teórico-metodológica pode ser encarada como um tipo de limitação, já que tais estudos acabam deixando de lado aspectos relevantes para a compreensão de fenômenos relacionados aos comportamentos de escolha ou decisão. Nesse sentido, uma abordagem psicológica, como por exemplo, a análise do comportamento, pode complementar a proposta da análise econômica do direito para o estudo do comportamento de magistrados. Pois além de prover uma alternativa teórica e metodológica, o que tende a 
enriquecer uma área de pesquisa, a análise do comportamento possui um arcabouço metodológico e teórico consolidado, fruto de pesquisa empírica tanto no campo da ciência básica quanto aplicada. Desse modo, o conhecimento acumulado em tais estudos pode servir de amparo metodológico e teórico para a investigação de fenômenos relativos a comportamentos jurídicos.

No que concerne a interação entre análise econômica do direito e psicologia, Foxall (2004) discute o modelo de utilidade proposto por Posner (1995) chamando atenção para a possibilidade de empregar variáveis tipicamente psicológicas para complementar as análises realizadas e sugerir novos tipos de estudos. Foxall propõe que além de variáveis relacionadas ao contexto e a características dos processos, as diferenças cognitivas entre os juízes também podem ser um fator decisivo para o tipo de voto realizado em uma decisão em colegiado. A partir disso, o autor discute que diferentes tipos cognitivos, como inovador, conservador ou adaptador, podem explicar as preferências de um juiz por determinados fatores previstos pela função de utilidade em detrimento de outros, e dessa forma, explicar e prever os padrões de preferência por um tipo do voto (e.g., aversão à dissidência).

Apesar do tipo de análise e elementos teóricos diferirem daqueles normalmente adotados em uma perspectiva analítico-comportamental, Foxall (2004) demonstra a possibilidade de uma abordagem baseada em variáveis descritas exclusivamente pela psicologia para investigar esse tipo de fenômeno. O autor também defende que uma análise que incorpore conceitos psicológicos e econômicos é mais capacitada a produzir hipóteses experimentais, assim como de interpretar e explicar os comportamentos jurídicos, pois essa abordagem teria um suporte teórico e metodológico mais rico e variado. Ou seja, se ressalta que a psicologia pode apresentar complementaridade aos estudos de análise econômica do direito sobre decisão de magistrados em colegiado. 
Como é salientado por Oliveira-Castro (2011), existe uma tradição em análise do comportamento em analisar e interpretar comportamentos humanos complexos. O autor também chama a atenção para o fato de que apesar dos estudos em análise do comportamento sobre temas relacionados ao direito e comportamento jurídicos não serem tão numerosos, eles podem apresentar contribuições interessantes e significativas para o desenvolvimento dessa área de pesquisa.

Nesse sentido, é possível mencionar o estudo de Todorov (2005) como um dos exemplos de contribuições baseadas em um arcabouço analítico-comportamental para o estudo de temas relacionados ao direito. Nesse estudo, o autor examinou o Estatuto da Criança e do Adolescente (ECA) a partir do uso do conceito de contingência tríplice e metacontingência, verificando como diferentes comportamentos descritos pelas leis podem estar relacionados uns aos outros. $\mathrm{O}$ autor demonstra análises e interpretações relevantes do sistema legal a partir de um paradigma operante, e conclui que boa parte das leis descritas no ECA não podem ser descritas a partir de uma contingência tríplice. Ou seja, seus antecedentes, comportamentos e consequências não estão bem especificados, o que implica em uma falta de clareza ao que exatamente essas leis se referem. O autor também discute que as leis geralmente se referem a comportamentos complexos, ou padrões de comportamento, o que em boa parte dos casos dificulta a sua descrição precisa. Esse tipo de análise permite contestar e sugerir reformulações de modo objetivo a partir de uma análise comportamental a esse tipo de conjunto de leis, pois demonstra que esse estatuto pode ser falho como um mecanismo de controle social eficiente, já que falta clareza quanto aos comportamentos e consequências que suas leis especificam.

Também é possível encontrar em Skinner (1953/2002) discussões sobre os efeitos das leis e agências governamentais sobre a sociedade e comportamento humano, onde se destaca que 
essas tem o papel primário de exercer controle sobre o comportamento dos indivíduos. Ou seja, para o autor, as leis são uma das principais ferramentas de controle social exercido por agências reguladoras, tais como o judiciário. O autor discute que esse controle ocorre sobretudo a partir de contingências programadas por agências reguladoras, tais como o judiciário, instituições educacionais ou religiosas. Tais contingências de controle envolvem principalmente reforço negativo, na medida em que as pessoas evitam punições ou sanções por seguirem a lei, ou seja, por se comportarem de certa forma e ou evitar emitir comportamentos considerados indesejáveis.

Apesar de trabalhos como os de Todorov (1987, 2005) e Skinner (1953/2002) apresentarem contribuições relevantes e demonstrarem o potencial da aplicação do paradigma behaviorista a fenômenos relacionados ao direito, talvez a proposta mais comprometida em investigá-los a partir desses princípios seja a análise comportamental do direito. A análise comportamental do direito (cf. Aguiar, 2006, 2013, 2014) adota o paradigma teórico e epistemológico da análise do comportamento para interpretar as leis, as práticas jurídicas, o comportamento de seus operadores e com isso explicar os efeitos desse sistema sobre o comportamento dos indivíduos na sociedade. De acordo com Aguiar, ao se amparar em elementos teóricos e metodológicos do paradigma operante para interpretar fenômenos tais como a forma que determinada lei afeta o comportamento das pessoas, essa proposta pode tornar o direito mais eficiente em produzir mudanças planejadas na sociedade. Ou seja, a análise comportamental do direito tem como um de seus principais intuitos possibilitar que direito seja uma ciência comportamental aplicada.

De acordo com Aguiar (2013, 2014), um dos principais focos de interesse da análise comportamental do direito se refere a análise funcional das leis, ou seja, é descrever como as leis ou normas jurídicas a partir do paradigma operante. Para o autor, a análise da lei envolve 
identificar a conduta descrita por ela. A partir disso, é necessário descrever precisamente o tipo de comportamento que deve ou não ocorrer em um determinado contexto, assim como a sanção ou incentivo relacionado a tal comportamento. Portanto, essa análise identifica os elementos descritos na lei a partir de seus antecedentes, comportamentos e consequências, que pode ser caracterizado como uma contingência jurídica. Também é necessário destacar que as consequências descritas e estabelecidas pelas leis geralmente são punições já que boa parte dessas leis tem o intuito de reduzir a frequência de comportamentos socialmente indesejáveis. Desse modo, ao seguir uma lei, o comportamento do indivíduo será reforçado negativamente, na medida em que se evita as punições por ela previstas (e.g., multas, inelegibilidade, prisão).

No que se refere a interpretação da principal função social das leis, é possível encontrar uma sobreposição entre análise do comportamento e análise econômica do direito. Tanto as análises realizadas por Skinner (1953/2002), Todorov (2005) quanto por Posner (1995, 2007) e Cooter (2000) sugerem que as leis possuem a função de aumentar ou diminuir a frequência de comportamentos alvo. No entanto, a proposta de Aguiar (2014) complementa tais interpretações, pois sugere que o conceito de meta social também é importante para a análise das funções das leis e normas jurídicas. Para o autor, as leis são implementadas para alcançar determinados objetivos em função de regular os comportamentos dos indivíduos em sociedade. Portanto, é possível entender que essa meta está relacionada aos objetivo que os legisladores tinham ao criar implementar uma lei. Por exemplo, ao se prever sanções para o mau uso de recursos públicos por administradores e funcionários públicos (cf. Art. 16 da Lei Orgânica do TCU, 2002), a meta social envolve reduzir o desvio de verbas e aumentar a frequência do uso eficiente de recursos. Ou seja, a lei promove que comportamentos socialmente desejáveis ocorram em detrimento 
daqueles que não favorecem o bem estar do grupo social. O modelo proposto por Aguiar pode ser verificado abaixo:

\{DADO QUE [as seguintes premissas comportamentais relevantes são válidas segundo o estado atual da ciência comportamental humana], SE [tal consequência mediata ou imediata da imposição da contingência jurídica abaixo é uma meta social, ou seja, um estado de coisas que presumidamente favorece o bem-estar do grupo social como um todo], ENTÃO [a seguinte contingência jurídica deve ser imposta pelo sistema jurídico (SE tal conduta, ENTÃO, tal sanção)]\} (Aguiar, 2014, p.265).

Para Aguiar (2014), a maneira mais direta de se descrever as leis a partir do paradigma analítico-comportamental é empregando o conceito de regras. Como pode ser verificado no modelo acima, as regras especificam contingências. Elas sinalizam que diante de determinado contexto (antecedente) certo comportamento (resposta) será seguido de uma consequência específica (reforço ou punição). As regras permitem que padrões de comportamento complexos, possam ser estabelecidos socialmente, sem que o indivíduo seja submetido diretamente a tal situação. Ou seja, permite um aprendizado por instrução, o que é a base de diversos estatutos, normativos profissionais e interações sociais complexas. Por exemplo, a lei estipula que mediante a um desvio de verba, o administrador deverá ser punido com multa e deverá restituir o valor desviado (cf. Art. 16 da lei orgânica do TCU, 2002). Essa lei na maneira como está escrita prevê uma contingência (antecedente-comportamento-consequência) para certos indivíduos (gestores de recursos públicos), e provavelmente aumenta a chance de se usar o dinheiro público corretamente em função de se evitar uma punição. Ao mesmo tempo, essa mesma lei também estabelece uma contingência para os operadores da lei, que diante da identificação de 
determinada infração devem aplicar tal sanção. Portanto, uma mesma lei pode estabelecer diferentes contingências, ou diferente situações do tipo SE-ENTÃO.

Em outras palavras, a partir do que propõe Aguiar (2014), é possível concluir que além de descreverem e especificarem contingências de reforço, a leis podem assumir outras funções para diferentes indivíduos na sociedade e do sistema jurídico. Por exemplo, para o destinatário da lei, que geralmente é o cidadão comum, a lei sinaliza que determinado comportamento deve ser realizado ou evitado. Já para um operador da lei, como um juiz ou até mesmo um policial, tal lei sinaliza que determinada sanção deva ser aplicada, ou que o comportamento de um cidadão deva ser coibido. Enquanto que para um advogado ou promotor, a lei sinaliza que certas providências procedurais deverão ser realizadas para certos tipos de caso.

Outra questão relevante que pode ser derivada a partir desse modelo se relaciona a influência real das leis sobre o comportamento das pessoas. Oliveira-Castro (2015) destaca que apesar de leis especificarem certas sanções com o intuito de controlar o comportamento dos indivíduos, é importante investigar qual a contingencia real que de fato está em vigor e influência os comportamentos das pessoas de modo determinante. Ou seja, em que contextos a lei prevista é seguida ou se existem outras contingências sobrepostas com consequências mais significativas que de fato controlam o comportamento dos cidadãos. Por exemplo, as sanções sinalizadas por determinada lei realmente inibem um comportamento indesejável?

Nesse sentido, a regra ou a lei enquanto elemento textual, não determinam o comportamento dos indivíduos e operadores da lei, mas possui uma função de variável de contexto para o comportamento, ou de modo mais específico, de estímulo discriminativo $\left(\mathrm{S}^{\mathrm{D}}\right)$. Ou seja, dentro de uma contingência mais ampla que também inclui elementos ambientais, essa possui a função de aumentar ou diminuir a probabilidade de ocorrência de enunciação de regras 
por parte dos indivíduos. Esse tipo de análise parece bastante promissora, tanto para o estudo empírico de fenômenos relacionados ao direito, quanto para tornar o direito uma ferramenta de engenharia social, tal como é proposto pela análise comportamental do direito (cf. Aguiar 2014).

Apesar de algumas distinções teóricas e metodológicas, a análise comportamental do direito e a análise econômica do direito se aproximam por ambas representarem uma abordagem naturalista sobre o direito, pois essas enfatizam os estudos empírico baseado em elementos ambientais acerca de fenômenos relacionados as práticas jurídicas. Além disso, conforme foi descrito anteriormente, existe uma ampla literatura baseada em economia sobre decisões de magistrados e sobre a influência da lei no comportamento das pessoas, de modo que tais estudos podem servir de importante referência para estudos posteriores baseados em análise do comportamento. Desse modo, vale a pena examinar com detalhe de que modo essas duas propostas teóricas podem interagir e se complementar no estudos de fenômenos relacionados ao direito. Isso também se salienta pois existe um histórico bem sucedido do uso de conceitos e metodologias provenientes da economia em diversas linhas de pesquisa em análise do comportamento (cf. Green \& Freed, 1998; Kagel, Battaglio \& Green 1995). Desse modo, essa interação também pode se provar útil no campo de estudo de fenômenos relacionados ao direito e principalmente para investigação decisões de magistrados em colegiado.

\section{Objetivos}

Diante do que foi exposto, é possível assumir que o comportamento de magistrados e decisões em colegiado são influenciadas por variáveis contextuais, características do processo assim como a variáveis relacionadas a características individuais. Ou seja, com base nos estudos empíricos e teóricos aqui expostos fica evidenciado que as decisões judiciais não são 
exclusivamente determinadas pela lei ou normativos, como as concepções mais tradicionais do direito tendem a assumir.

Muitas das evidências empíricas dos trabalhos aqui descritos se referem a decisões de colegiado de cortes jurídicas que empregaram um nível de análise de grupo, no entanto, apesar de buscar amparo e realizar comparações com esse tipo de literatura, o presente trabalho apresenta diferenças e inovações significativas tanto teóricas como metodológicas. Primeiramente, o presente estudo se afasta da literatura tradicional por se focar em comportamentos do relator do processo (i.e., sanções), e não em votos do colegiado como um todo. Além disso, os comportamentos jurídicos foram investigados em um contexto distinto e original em relação as pesquisas anteriores, que se refere ao colegiado de uma corte de contas brasileira (TCU). Outro aspecto original do presente trabalho se refere ao fato de que ele pretende integrar metodologias e recursos teóricos tanto da análise econômica do direito quanto da análise do comportamento para investigar e expandir o conhecimento sobre esse tipo de fenômeno.

Para investigar tais aspectos, o presente trabalho descreve uma proposta de verificar se variáveis relacionadas ao contexto da decisão, a características do processo e a características individuais dos relatores do processo influenciam as decisões feitas em colegiado de Ministros e Ministros-substitutos do Tribunal de Contas da União (TCU) em processos de tomada de contas especial (TCE). Como será discutido em detalhe posteriormente, o TCU tem a característica de órgão colegiado, sendo que esse é composto por Ministros e Ministros-substitutos. Apesar de ser uma corte de contas administrativa (cf. TCU, 2015), o contexto e características das atividades profissionais, de carreira e das decisões em colegiado exercidas por seus Ministros e MinistrosSubstitutos apresentam grande proximidade com aquelas das cortes jurídicas, tais como o TSE 
ou os TRFs. Portanto, em virtude dessa proximidade, é possível usar uma lógica semelhante para analisar, interpretar e comparar as regularidades encontradas em decisões de ministros e ministros-substitutos com aquelas verificadas para magistrados. Além disso, ao se verificar a generalidade desses fenômenos em outro contexto profissional e de decisão em colegiado, ficaram salientadas quais variáveis e processos básicos se relacionam a esse tipo de fenômeno, o que ajuda a tornar os resultados desse campo de pesquisa ainda mais robustos.

Como já foi mencionado anteriormente, o presente trabalho irá diferir da literatura tradicional que investiga decisões judiciais em colegiado quanto à metodologia e arcabouço teórico empregado para analisar e interpretar os resultados, e nesse ponto representa uma proposta de estudo original. Portanto, um dos objetivos principais desse trabalho é de fundamentar, construir e testar uma proposta de análise econômico-comportamental operante para comportamentos jurídicos. Desse modo, o objetivo do primeiro estudo do presente trabalho (Estudo 1) foi de desenvolver um modelo teórico e metodológico que integre elementos da análise do comportamento, o que inclui a análise comportamental do direito, e a análise econômica do direito para investigar empiricamente decisões em colegiado de ministros do TCU. Desse modo, para alcançar esse objetivo, foram discutidos pontos de sobreposição e complementaridade entre tais abordagens onde se evidenciou as vantagens de uma proposta teórico-metodológica que integre elementos dessas duas linhas de pesquisa.

Para o desenvolvimento de uma proposta econômico-comportamental operante para o estudo de decisões de magistrados em colegiado será empregado como base teórica o Modelo na Perspectiva Comportamental ou Behavioral Perpective Model (BPM) (Foxall, 1990, 2002, 2010). Como será apresentada em detalhe no Estudo 1, esse modelo se caracteriza como um exemplo bem sucedido de integração de metodologias e conceitos da economia e análise do 
comportamento e apresenta algumas inovações conceituais que ajudam a caracterizar de modo mais preciso os elementos que compõem as contingências relacionadas as decisões dos ministros e ministros-substitutos do TCU sobre processos de TCE.

Por fim, o modelo desenvolvido no Estudo 1 será testado em dois estudos empíricos que irão investigar decisões de colegiado de ministros de TCU (Estudos 2 e 3). Portanto, além desses estudos terem atendido ao propósito de investigar regularidades acerca de um fenômeno onde praticamente não foi realizado nenhum tipo de estudo empírico, esses também serviram como teste do modelo. Além disso, por terem um caráter exploratório e pela relativa originalidade do objeto do assunto, esses estudos poderão servir para embasar diversas investigações futuras mais detalhadas.

Baseando-se nesses critérios, o Estudo 2 (primeiro estudo empírico) teve o objetivo de investigar as decisões em colegiado em processos de Tomada de Contas Especial (TCE) no TCU. Esse estudo diferiu dos estudos de análise econômica do direito que tendem a se focar em decisões do colegiado enquanto grupo, pois foram analisadas as decisões do relator do processo. A partir disso, foi investigado como essas decisões (sanções) podem variar em função do colegiado onde o processo de TCE foi tramitado (e.g., $1^{\text {a }}$ Câmaras vs. Plenário). Conforme será melhor abordado posteriormente, os relatores dos processos podem ser Ministros ou Ministrossubstitutos, enquanto suas decisões no contexto do presente estudo foram as sanções (e.g., multa, inabilitação) que esse propôs em acórdão para ser votada em colegiado para o gestor que cometeu dano ao erário. Além de investigar o colegiado onde ocorreu a decisão como uma variável independente relacionada a diferenças em sanções estabelecidas pelos relatores dos processos, também foram investigadas a influência de outras variáveis contextuais. Portanto, de modo semelhante a estudos de análise econômica do direito, mas empregando uma interpretação 
estabelecida no Estudo 1, essas variáveis se relacionam a características do processo e do contexto da decisão em colegiado, tais como: o valor do dano ao erário, o cargo ocupado pelo gestor de recursos públicos que cometeu a infração e o tipo específico de infração (e.g., desvio, desfalque, omissão).

Já o Estudo 3 investigou se variáveis relacionadas a histórico de aprendizagem de comportamentos jurídicos estão relacionadas a diferenças nas decisões dos relatores em processos de TCE do TCU. Baseando-se nos critérios estabelecidos no Estudo 1, as variáveis relacionadas a histórico de aprendizagem de comportamentos jurídicos foram delimitadas como: o cargo atual do relator; e o cargo ocupado pelo relator antes de ser nomeado como Ministro ou Ministro-substituto do TCU. Por fim, no Estudo 3 também foi investigado se existem diferenças a nível individual nas sanções estabelecidas pelos relatores dos processos de TCE. Desse modo, ao se investigar tais regularidades, será possível identificar com mais clareza os padrões de decisões e suas diferenças individuais entre os relatores de processos do TCU em função de variáveis contextuais, características relativas ao processo e sobretudo de seu histórico de aprendizagem de comportamentos jurídicos. Ou seja, além de explorar em mais detalhes as regularidades que foram constatadas no estudo anterior, o Estudo também buscou identificar diferenças individuais em padrões de comportamentos jurídicos de magistrados em decisões colegiadas.

\section{Estudo 1}

O primeiro estudo do presente trabalho tem caráter teórico. O objetivo consistiu em propor um modelo que permitisse interpretar e investigar regularidades acerca de comportamentos relacionados a decisões de magistrados em colegiado a partir de uma perspectiva econômico-comportamental de base operante. Se referindo de modo mais específico 
aos objetivos gerais da tese aqui apresentada, esse estudo inicial serviu de fundamento teórico e metodológico para dois estudos empíricos (Estudo 2 e 3) que foram conduzidos para investigar regularidades acerca de decisões em colegiado de Ministros ou Ministros-substitutos do TCU em processos de Tomada de Contas Especial.

Como já foi apresentado anteriormente, uma das linhas de pesquisa em análise econômica do direito estuda o comportamento de decisão de magistrados em contexto de colegiado (cf., Epstein, et al., 2013). Como será explicado posteriormente de modo detalhado no Estudo 2, o TCU não é uma instituição jurídica, mas sim, administrativa. No entanto, muitas variáveis tipicamente associadas ao contexto de decisões judiciais estão presentes durante os processos decididos em colegiado no TCU, tais como as leis e a estrutura de colegiado. Portanto diversos paralelos podem ser traçados entre a atividade de ministros, ministros-substitutos e juízes, o que justifica a investigação desse contexto distinto de decisão empregando como base para comparação a literatura de análise econômica do direito.

Por exemplo, apesar de processos administrativos sobre responsabilidade fiscal (i.e., TCE) serem distintos de processos judiciais criminais, cíveis ou trabalhistas, todos esses são amplamente amparados por um normativo e por leis que restringem e estabelecem cursos específicos de ação, tanto para ministros, e ministros-substitutos quanto para juízes. Outro ponto de interseção se refere ao fato do contexto escolhido para o presente estudo ser um colegiado, de modo que o voto dos pares determinará se uma determinada sanção será imposta ou não nos processos de TCE. Portanto, o contexto onde ocorre o comportamento de escolha e decisão em colegiado do TCU é muito semelhante ao de juízes em diversos estudos de análise econômica do direito (e.g., Epstein et al., 2011, 2013), onde já foi verificado que a interação com o grupo é um dos fatores determinantes sobre as decisões judiciais. 
Além disso, elementos definidos por Posner (1995, 2007) e Epstein et al. (2011, 2013) como incentivos, punições ou restrições para a carreira de Juízes como variáveis que podem influenciar as suas decisões em colegiado, também são muito semelhante para os Ministros e Ministros-substitutos do TCU. De modo que circunstâncias de progressão de carreira, estabilidade profissional, prestígio social da profissão e eventuais reprimendas ou feedback negativo em função de terminadas decisões judiciais ou administrativas são diretamente comparáveis. Considerando tais fatores, um dos objetivos e contribuições do presente estudo também consiste em construir um modelo que permita comparar de modo mais objetivo os padrões de escolha e decisão observados em juízes em contexto de colegiado com os comportamentos de Ministros e Ministros-substitutos do TCU em processos de TCE que serão verificados nos estudos empíricos posteriormente presentados (Estudos 2 e 3).

\section{Método: Estrutura da análise teórica}

Um dos fundamentos centrais que foram adotados na proposta teórica aqui apresentada foi o Behavioral Perspective Model (BPM) ou Modelo na Perspectiva Comportamental (cf. Foxall, 2010). Esse modelo foi empregado como principal base para a esse estudo e como está melhor apresentado a frente, ele representa um exemplo bem sucedido de integração de conceitos e metodologias provenientes da análise do comportamento e economia. O BPM tem sido empregado de modo quase que exclusivo para o estudo de fenômenos relacionados ao comportamento do consumidor, no entanto, mais recentemente, essa proposta tem sido estendida para estudar o comportamento em outros tipos de contexto, tais como o jurídico (cf. Pinheiro \& Oliveira-Castro, 2015). Apesar de se amparar em princípios comportamentais operantes (cf. Skinner 1953), o BPM traz inovações e adaptações conceituais que podem ser vantajosas e complementares para o estudo de comportamentos relacionados ao direito. Como também será 
demonstrado adiante, esse modelo teórico pode ajudar a qualificar e classificar de modo mais preciso algumas das variáveis relacionadas ao contexto das decisões em colegiado. Além disso, será demonstrado como esse modelo também permite interpretar de modo complementar os resultados empíricos provenientes de estudos baseados em análise econômica do direito a partir de uma perspectiva operante.

Ainda no que concerne ao desenvolvimento de uma proposta de análise econômicocomportamental operante para o estudo de decisões de ministros do TCU, também foram consideradas as contribuições metodológicas e teóricas de duas linhas de pesquisa: a análise econômica do direito (e.g., Posner, 1995) e a análise comportamental do direito (e.g., Aguiar, 2014), que tem como base os princípios operantes (cf. Skinner 1953). Essas duas propostas foram desenvolvidas a partir de um embasamento científico e empírico com o intuito de investigar fenômenos relacionados ao contexto jurídico de modo dedicado. Desse modo, apesar de existirem algumas diferenças epistemológicas e metodológicas entre uma proposta puramente econômica e a análise do comportamento, é importante analisar as suas contribuições de modo integrado. Portanto, o presente estudo consistiu em empregar o BPM como um arcabouço base para integrar elementos teóricos e metodológicos provenientes da análise econômica do direito e da análise comportamental do direito (análise do comportamento).

Primeiramente foram feitas algumas considerações acerca de interações teóricas e metodológicas entre abordagens baseadas em economia e a análise do comportamento. Essa discussão foi realizada visando destacar como conceitos e métodos de investigação desses duas abordagens podem ser empregados de modo complementar. Após isso, foi apresentado o BPM, onde se discutiu de que modo ele pode servir de base para o estudo de decisões de magistrados em colegiado. Por fim, será apresentado um sumário do modelo econômico-comportamental 
operante baseado no BPM onde constam interpretações justificadas teoricamente para todas a variáveis que foram empregadas nos estudos empíricos posteriormente conduzidos (Estudo 2 e 3). Portanto, o resultado do presente estudo produziu um modelo que integra conceitos provenientes da análise econômica do direito e análise comportamental do direito interpretados a luz do BPM para analisar variáveis relacionadas ao contexto de decisão em colegiado de Ministros e Ministros substitutos do TCU em processos de TCE.

Interações entre economia e análise do comportamento. Skinner (1943/2002) afirma que uma ciência do comportamento adequada, no caso a análise do comportamento, deve ser capaz de prover explicações para os dados providos pela economia. Essa afirmação visava enfatizar o comportamento como um objeto legítimo de estudo empírico e estabelecer fronteiras de trabalho para a consolidação da análise do comportamento enquanto ciência. Porém, a consequência inicial desse tipo de postura epistemológica favoreceu um afastamento entre essas áreas, principalmente pela parte dos analistas do comportamento. No entanto, conforme as pesquisas empíricas em análise do comportamento foram expandindo seus campos de atuação, a interação teórica e metodologia entre economia e análise do comportamento começou a ser implementada. Esse tipo de interação pode ser encontrada em autores como Hursh (1980, 1984), que argumenta que os conceitos operantes e econômicos podem atuar de forma complementar para produzir avanços na compreensão de fenômenos comportamentais.

Atualmente existem diversos exemplos de adaptações e inovações provenientes da economia que vieram a contribuir com o desenvolvimento da análise do comportamento como campo de pesquisa (cf. Bickel, Odum, \& Madden, 1999; Bickel \& Marsch, 2001; Green \& Freed, 1998; Hursh, 1980, 1984; Hursh \& Silberberg, 2008; Kagel, Battaglio \& Green 1995). Esses novos elementos teóricos e metodológicos surgiram justamente de demandas por 
explicações e práticas encontradas durante pesquisas empíricas, de modo que tais elementos se remetem a lacunas e aspectos específicos relativos a explicação de fenômenos que até então, não eram abordados em análise do comportamento.

Um dos pioneiros a demonstrar a utilidade da incorporação de conceitos econômicos em análise do comportamento foi Hursh (cf. 1980). O autor discutiu inconsistências entre resultados de estudos empíricos com delineamentos experimentais considerados idênticos, e afirmou que sem o uso de conceitos econômicos, tais diferenças entre experimentos não poderiam ser explicadas de forma satisfatória. As divergências entre resultados desses experimentos se referiam ao desempenho de animais privados de alimento (pombos e ratos) em esquemas de reforçamento com razão fixa progressivamente maior (e.g., FR: 20, 40, 80), no qual uma resposta simples produzia alimento. O que se constatou é que enquanto em alguns experimentos os sujeitos apresentaram altas taxas de resposta, o que condiz com o tipo de delineamento empregado, em outros as taxas de resposta foram bem mais baixas.

A partir da análise das variáveis envolvidas no experimento, Hursh (1980) propôs que a única forma de explicar as diferenças entre os resultados de tais experimentos era adotando os conceitos de sistemas econômicos fechados e abertos. Em termos mais específicos do contexto experimental, em uma economia aberta o consumo dos reforçadores (e.g. alimento ou fluido) não ocorre exclusivamente em sessões experimentais, enquanto que em economias fechadas, esse consumo total ocorre apenas em função de sessões experimentais (Green \& Freed, 1998; Hursh, 1980, 1984; Kagel, et al., 1995). Nos experimentos analisados por Hursh, apesar de ter sido adotado um procedimento de privação de alimento idêntico, existiram diferenças quanto ao sistema econômico no qual os sujeitos estavam inseridos. Portanto, se verificou que nos estudos em que os sujeitos apresentaram altas taxas de resposta foi empregada uma economia fechada, 
enquanto que nos estudos em que ocorreram taxas de reposta mais baixas, utilizou-se uma economia aberta. Desse modo, foi identificado um novo tipo variável independente, e que apesar da influência determinante que exerce no comportamento, era anteriormente desconsiderada em pesquisas de análise do comportamento.

A partir de trabalhos pioneiros como os de Hursh (1980), cada vez mais os conceitos e metodologias com origem na economia foram sendo incorporados em pesquisas de análise do comportamento. Autores como Hursh, Madden, Spiga, DeLeon, \& Francisco, (2013) e Reed, Niileksela, e Kaplan, (2013) definem o campo da economia comportamental como uma área que integra princípios microeconômicos e das ciências comportamentais, onde os estudos mais prevalentes possuem uma base teórica cognitivista (e.g., Jolls, Sunstein \& Thaler, 1998; Kahneman, \& Tversky, 1984; Sunstein, 1997; Sunstein, Kahneman \& Schkade, 1998).

Sobretudo no que concerne a economia comportamental de base operante, esse é um campo de pesquisa com um número relativamente menor de trabalhos, mas que oferece um modelo de trabalho vantajoso para estudos sobre consumo e alocação de comportamento. Já Green e Freed (1998) enfatizam que a incorporação de metodologias e conceitos econômicos permitiu investigar novas dimensões de fenômenos comportamentais, tais como interações entre diferentes reforçadores. Os autores também salientam que o desenvolvimento de uma economia comportamental de base operante abriu espaço para novas linhas de pesquisa empírica e mostrou benefícios para o contexto de aplicação prática. Tais pesquisas abordam os mais variados fenômenos, dentre eles: escolha e decisão, impulsividade e autocontrole, persistência, sensibilidade ao reforço e drogadição. Essas pesquisas exemplificam uma abordagem econômico comportamental de base operante e são conduzidas tanto com humanos (e.g., Bickel \& Marsch, 
2001; Navarro \& Fantino, 2009) quanto com animais (e.g., Kagel, et al., 1995; Macaskill \& Hackenberg, 2012).

O modelo na perspectiva comportamental (BPM). Um dos exemplos em que a incorporação de conceitos e metodologias provenientes da economia ofereceu contribuições significativas para a análise do comportamento pode ser verificado em pesquisas da área do comportamento do consumidor. Com o intuito de melhor abordar as características particulares dos fenômenos relacionados a essa área, e oferecer uma alternativa teórica e metodológica que contrastasse com os modelos de pesquisa dominantes (e.g., administração, marketing, psicologia social-cognitiva), Foxall (1990, 2002, 2010) desenvolveu o Modelo na Perspectiva Comportamental ou Behavior Perspective Model (BPM). O BPM representa uma proposta de abordagem econômico-comportamental de base operante, e, portanto, se ampara no arcabouço teórico e metodológico da análise do comportamento. Essa proposta também se ampara nos resultados de pesquisa básica e aplicada em análise do comportamento área para investigar os mais variados fenômenos relacionados ao contexto do comportamento do consumidor. Dentre os fenômenos mais estudados em pesquisas baseados no BPM, é possível mencionar escolha de marcas (cf. Foxall, Oliveira-Castro \& Schrezenmaier, 2004; Oliveira-Castro, Foxall \& Schrezenmaier, 2006), diferenças individuais em padrões de compra (cf. Cavalcanti, OliveiraCastro \& Foxall, 2013; Oliveira-Castro, Cavalcanti, \& Foxall, 2015, Oliveira-Castro et al., 2016), e comportamentos pró-ambientais de descarte de lixo e conservação de energia (cf. Foxall, Oliveira-Castro, James \& Yani-de-Soriano, 2006).

Como é possível verificar na Figura 1, o BPM apresenta algumas adaptações e inovações conceituais ao modelo clássico de contingência tríplice proposto por Skinner (cf.1953/2003). No que se refere aos antecedentes, o modelo destaca basicamente dois elementos, o cenário de 
consumo e o histórico de aprendizagem, que nesse caso se refere diretamente a experiências relacionadas ao consumo de produtos e serviços específico. Já o conceito de cenário de consumo, concerne ao sistema econômico (cf. Hursh, 1980, 1984) relacionado a situação de consumo, de modo que essa variável independente sempre está presente nas análises realizadas em pesquisas que empreguem esse arcabouço teórico. Em um contexto mais específico da pesquisa sobre comportamento do consumidor, economias abertas e fechadas estão relacionadas à quantidade de alternativas de reforço (e.g., mais alternativas, economia relativamente mais aberta), e eventuais restrições ou exigências impostas pela situação de compra (e.g., quanto mais restrições, mais fechado é o sistema econômico).

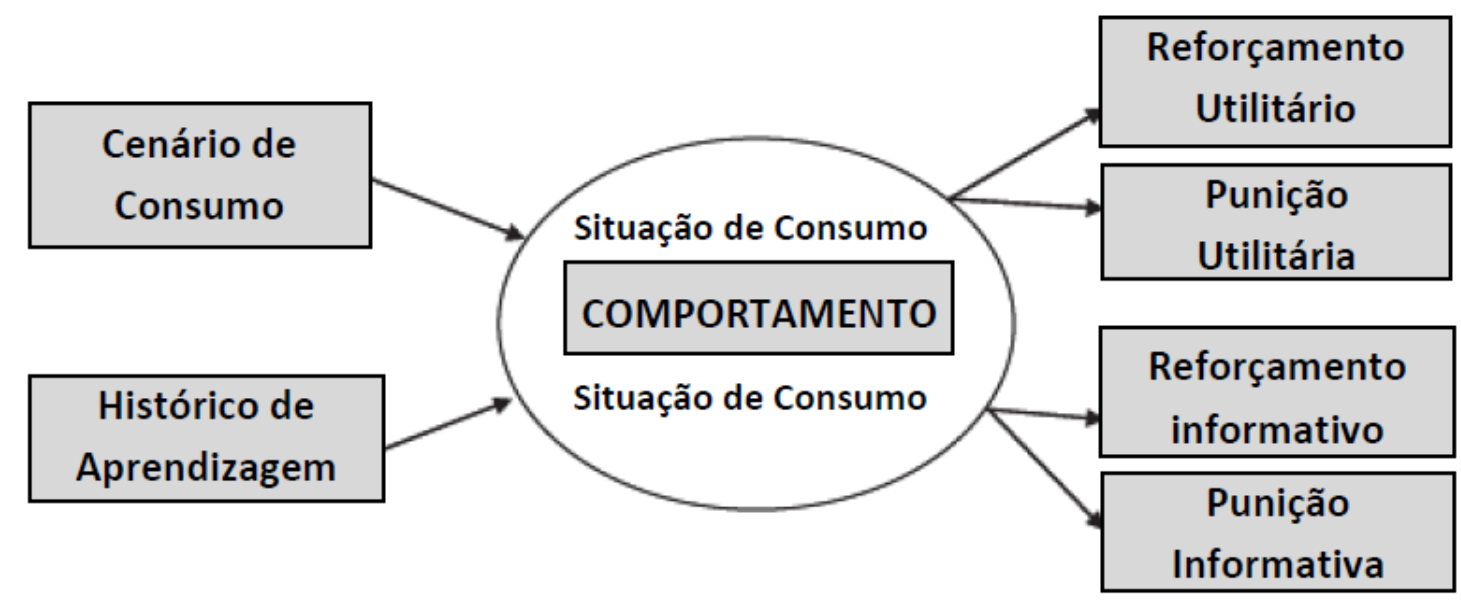

Figura 1. Esquema do Modelo na Perspectiva Comportamental - BPM. Adaptado de Foxall, (2010).

Também é possível verificar na Figura 1 algumas diferenças quanto às definições tradicionais em análise do comportamento no que concerne às consequências do comportamento. Os conceitos de consequências utilitárias e informativas são empregados para qualificar de modo mais preciso os punidores e reforçadores. E de acordo com a proposta do BPM essa qualificação é empregada com o intuito de verificar a qual propriedade do reforço determinado padrão de 
comportamento está associado. Foxall (1990, 2002, 2010) também destaca que todo comportamento produz tanto consequências utilitárias quanto informativas, no entanto, essas variam em intensidade.

As consequências utilitárias estão relacionadas às características físicas do reforçador ou punidor, de modo que no contexto de comportamento do consumidor, os reforçadores utilitários estão diretamente ligados aos benefícios práticos de se obter um determinado produto ou serviço. Aspectos como preço, distância do ponto de vendas e tempo gasto durante a situação de compra também podem ser interpretados como consequências utilitárias (Foxall, 1990, 2002, 2010).

Quanto ao conceito de reforço informativo, esse se relaciona a fatores simbólicos do contexto de compra, tais como feedback social, status ou prestigio, e apresenta grande sobreposição com o que Skinner (1957/1992) define como reforço verbalmente e socialmente mediado. No entanto, Foxall $(1992,2002,2010)$ destaca que o conceito de reforço e punição informativa também mede como um produto ou marca tem seu reconhecimento e qualidade avaliados pelos consumidores. Por exemplo, adquirir produtos de uma marca líder de mercado, que é consensualmente descrita como famosa e de alta qualidade, irá mediar mais reforço informativo (i.e., mais feedback social) do que a compra de uma marca relativamente desconhecida.

Foxall (1990, 2002, 2010) afirma que todo comportamento, a despeito de produzir consequências reforçadoras, possui um custo, seja esse em termos monetários, de tempo ou de esforço, e esse custo do comportamento é comumente caracterizado como punição utilitária. Também é preciso destacar que na maior parte dos casos, o comportamento irá produzir tanto consequências reforçadoras utilitárias quanto informativas, sendo que essas tendem a variar em sua proporção em situação de consumo. Desse modo, é possível observar que o comportamento 
dos consumidores poderá ocorrer mais em função de características utilitárias ou informativas mediadas pelo consumo de determinados produtos ou serviços, e isso irá apresentar variação em função da categoria do produto e de diferenças individuais. Portanto, o comportamento do consumidor será um produto da interação entre o custo comportamental ou monetário e os benefícios sociais e práticos relacionados à aquisição de um produto.

Além de adaptações teóricas da contingência tríplice, as pesquisas baseadas no BPM também incorporam diversos outros conceitos econômicos, que podem ser interpretados tanto quanto variável dependente quanto independente. Por exemplo, no que se refere ao conceito de elasticidade de demanda (Cavalcanti et al., 2013; Foxall et al., 2004, Oliveira-Castro et al., 2006), que representa a variação da quantidade comprada em função de variações no preço, se verificou que esse é um padrão de comportamento consistente tanto em análises de grupo, quanto individuais para diversas categorias de produto. Pesquisas empregando a conceito de valor essencial do reforço ou commodity (Oliveira-Castro, Foxall, Yani, \& Wells, 2011), que é uma técnica que permite comparar o consumo de reforçadores qualitativamente diferentes, também foi empregado para reforçadores utilitários e informativos. Enquanto que e o uso dos conceitos de bens complementares e substitutos (Foxall, 1999) demonstrou como o consumo de certos produtos ou marcas, pode variar em função do consumo de outros.

Outra inovação e possibilidade oferecida pelas pesquisas sobre escolha baseadas no BPM pode ser verificada no estudo de Oliveira-Castro et al. $(2015,2016)$, que utilizaram uma função de utilidade para investigar o comportamento de compra de produtos rotineiros de supermercado de consumidores. A premissa adotada por Oliveira-Castro e colaboradores para maximização de utilidade assume que os consumidores buscam obter o máximo de reforçadores utilitários e informativos possíveis em uma situação diante de uma restrição orçamentária. Ou seja, ao invés 
de definir utilidade em um sentido vago, como satisfação ou prazer, os autores propuseram que a utilidade em situações de consumo se refere a reforçadores utilitários e informativos. Os resultados obtidos para quatro categorias de produtos com cerca de 1600 consumidores indicaram um bom ajuste dos dados a função de utilidade baseada nas premissas do BPM. Portanto, esses resultados indicaram que de fato os consumidores maximizam reforçadores utilitários e informativos, e, além disso, os parâmetros obtidos foram consistentes ao longo do tempo, permitindo identificar diferenças individuais quanto à maximização.

Ao se comparar as variáveis descritas pelo modelo de maximização proposto por Oliveira-Castro et al. (2015, 2016) com alguns dos modelos empregados em análise econômica do direito (Epstein et al., 2011, 2013; Posner, 1995, 2007), é possível verificar que existem muitos pontos de congruência. Apesar das diferentes funções se referirem a contextos de escolha e a comportamentos totalmente distintos, as categorias de variáveis descritas pelos dois tipos de modelo são bem semelhantes, no sentido que essas podem ser interpretadas a partir dos conceitos de consequências utilitárias e informativas propostos pelo BPM. Por exemplo, o tipo de função de utilidade usada pelos autores em pesquisas sobre decisões de magistrados em colegiado destaca que variáveis como prestígio, e tempo livre são fatores a serem maximizados nesse contexto. Também se destaca nesse modelo que elementos como carga de trabalho e indisposições com colegas de trabalho tendem a ser evitados. Considerando o arcabouço teórico do BPM, as variáveis prestígio e indisposições com colegas podem ser descritas como sendo, respectivamente, reforço e punição informativa, pois estão relacionados a status e feedback social. Enquanto que o tempo livre e carga de trabalho representam reforço e punição utilitária, pois se referem aos benefícios práticos e custo comportamental decorrentes de uma decisão judicial em particular. 
A comparação entre os dois modelos indica que em ambos os casos, reforçadores informativos e utilitários são buscados ou maximizados (e.g., prestígio, tempo livre, produtos de qualidade), enquanto que punidores tendem a ser evitados ou minimizados, (e.g., custos comportamentais, monetários e de tempo). Essa comparação também demonstrou que é possível descrever com precisão as variáveis envolvidas em situações de escolha totalmente distintas a partir do BPM, de modo que o modelo não precisa se restringir ao comportamento de escolha de consumidores. Ou seja, essa comparação evidencia que o paradigma teórico e metodológico proposto pelo BPM pode ser ampliado para outros contextos de escolha, tais como de decisões judiciais e administrativas em colegiado, já que o modelo oferece uma base útil para descrever as variáveis presentes nesses contextos.

Ainda no que concerne à extensão do BPM para a investigação de outros tipos de escolha, Pinheiro e Oliveira-Castro (2015) demonstraram essa aplicação no contexto das práticas jurídicas em um estudo que examinou o comportamento de escolha das partes envolvidas em audiências de conciliação de litígios em causas trabalhistas. O estudo propõe que o contexto desse tipo de audiência judicial pode ser interpretado a partir de uma contingência tríplice onde está vigente um esquema concorrente com duas alternativas distintas de reforçamento. Nesse contexto, a proposta de acordo oferecida e discutida pelos advogados seria uma alternativa de reforço mais imediato e de menor magnitude, enquanto que a sentença imposta pelo juiz se caracteriza como um reforçador mais atrasado, de maior magnitude e probabilístico, pois o resultado do processo é incerto. A partir dessa proposta, os autores sugerem que ao se investigar como o comportamento de escolha é alocado entre essas duas alternativas, é possível verificar regularidades acerca de que variáveis estão relacionadas aos padrões típicos de escolha observados em tais audiências. 
Pinheiro e Oliveira-Castro (2015) também empregaram o conceito de consequências ambientais definido pelo BPM para qualificar as consequências decorrentes do comportamento de escolha em sessões de conciliação. De modo que os autores destacaram que tanto dimensões utilitárias (e.g. ganho monetário) quanto informativas (e.g., aprovação social por vencer a causa) dos reforçadores podem exercer influência direta sobre os padrões de preferência observados nesse contexto. Apesar dessa proposta ainda carecer de um teste empírico, ela indica a possibilidade do BPM ser aplicado ao contexto jurídico, e, portanto, enfatiza que ele pode ser estendido com sucesso para outras situações de escolha, tal como das decisões judiciais em colegiado.

Conforme foi discutido, a proposta do BPM, que basicamente consiste na utilização de uma contingência tríplice adaptada e na integração de conceitos e metodologias da economia, se mostrou bastante útil e preciso para encontrar regularidades no comportamento de escolha de consumidores (e.g., Cavalcanti et al., 2013; Foxall et al., 2004; Foxall, et al., 2006; OliveiraCastro et al., 2006; Oliveira-Castro et al., 2015, 2016; Oliveira-Castro \& Foxall, 2013). A partir das discussões aqui apresentadas, também se enfatizou que a análise do comportamento e o BPM apresentam grande complementaridade com a economia e consequentemente com a análise econômica do direito, e que a premissa econômica de racionalidade não inviabiliza a integração entre as áreas. Desse modo, a seguir será apresentado o modelo econômico-comportamental operante para o estudo de decisões de operadores da lei em colegiado. Para se adequar ao contexto específico da presente tese, estão interpretadas as variáveis específicas que podem influenciar as sanções estabelecidas pelos relatores em processos de TCE de acordo com esse modelo. Portanto, além de demonstrar como variáveis relacionadas ao contexto de decisão em 
colegiado podem ser interpretadas, o modelo também servirá de base para os estudos empíricos apresentados a frente (Estudo 1 e 2).

Resultados e Discussão: O modelo econômico-comportamental operante para decisões em colegiado

A Figura 2 apresenta um modelo baseado no BPM que sumariza e identifica as funções de todas as variáveis que serão empregadas nos estudos empíricos posteriores sobre decisões de relatores em processos de TCE (Estudos 2 e 3). Como é possível verificar na Figura 2, o modelo representa o resultado de uma análise preliminar das variáveis que serão analisadas nos estudos empíricos, tais como sanções e características do processo (e.g., acórdãos total, duração do processo). Porém, também estão representadas no modelo variáveis essenciais ao contexto de decisões jurídicas em colegiado trazidas tanto pela análise econômica do direito quanto pela análise comportamental do direito. A seguir estão descritas cada um dos grupos de variáveis que compõem o modelo, e como elas foram interpretadas empregando o BPM como base teórica e integrando elementos da análise econômica do direito, análise comportamental do direito. O elementos do modelo estão apresentados na seguinte ordem: (a) antecedentes (cenário da decisão e a lei), (b) histórico de aprendizagem, (c) comportamentos jurídicos e por fim, (d) as consequências do comportamento jurídico (utilitárias e informativas).

Antecedentes: Cenário da decisão. Conforme já foi abordado anteriormente, um dos conceitos provenientes da economia incorporados na contingência tríplice pelo BPM, é o de cenário. Esse conceito está diretamente relacionado ao contexto onde o comportamento ocorre, de modo que esse pode impor restrições que favorecem certos padrões de comportamento ocorrerem em detrimento de outros. 


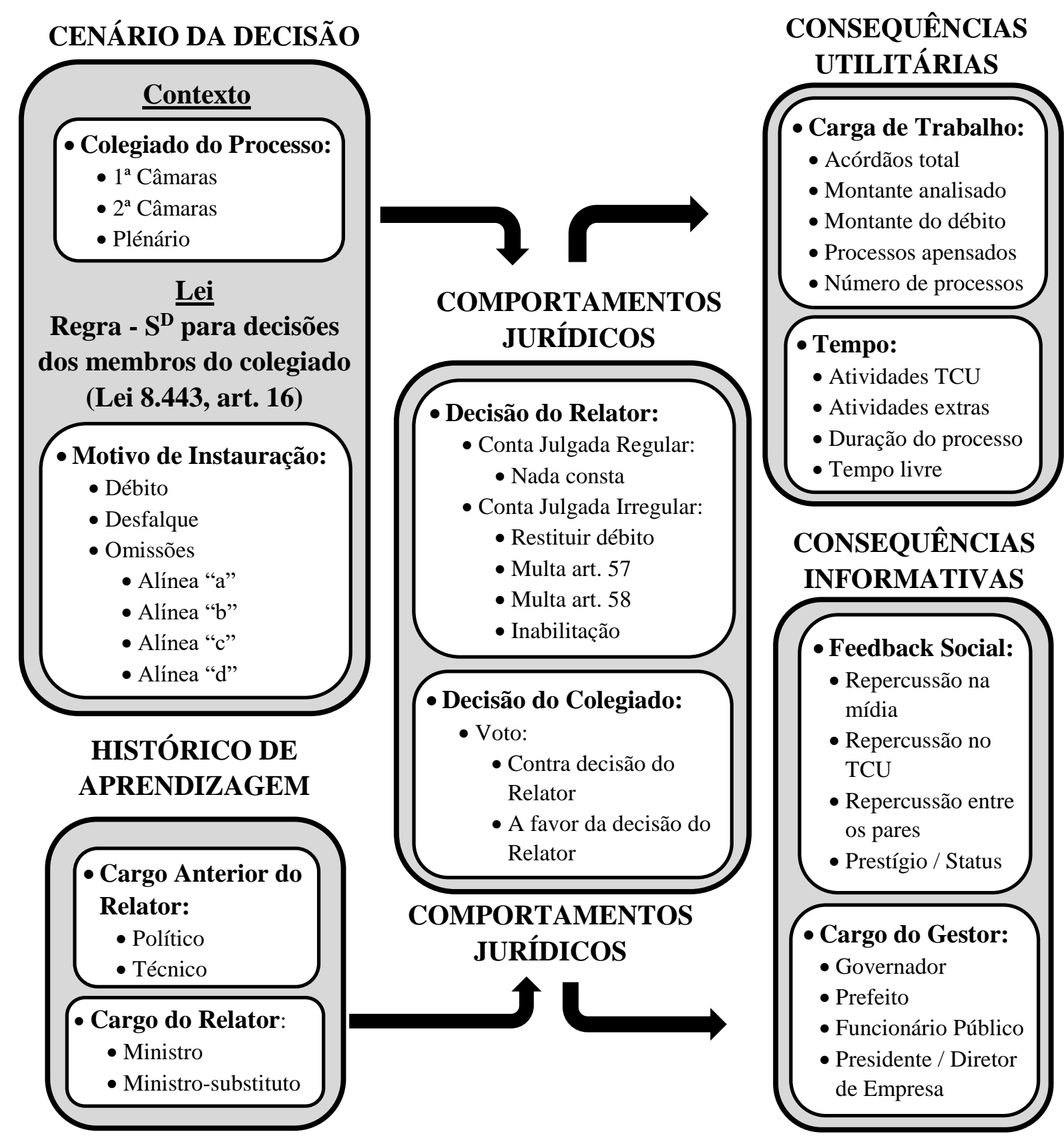

Figura 2. Modelo econômico-comportamental operante para decisões em colegiado. O modelo é baseado contingência tríplice proposta pelo BPM (Foxall, 2010).

Baseando-se no modelo do BPM, é possível caracterizar o colegiado como uma variável de cenário. Esse tipo de interpretação é possível pois o colegiado se refere o contexto onde a 
decisão judicial será emitida e eventualmente produzirá consequências (e.g., influenciará cidadão ou outros operadores da lei). Como foi verificado em estudos que examinaram efeitos de cenário (e.g., Hursh, 1980, 1984), suas características (aberto vs. fechado) podem influenciar o comportamento do indivíduos. Enquanto que estudos de análise econômica do direito (e.g., Edwards, 2003, Kastelac, 2007; Kim, 2009) verificaram que as características do colegiado, tais como sua composição, influenciam os decisões dos magistrados. Ou seja, é possível interpretar as características contextuais jurídicas e processuais a partir de em um continuo entre um cenário relativamente aberto e fechado, na medida em que impõem restrições acerca do tipo de decisão que o operador da lei emite

É comum verificar em estudos de análise econômica do direito uma interpretação que estabelece um relação causal quase que direta das variáveis que podem ser classificadas como de cenário, tais como o colegiado (e.g., Edwards, 2003, Kastelac, 2007; Kim, 2009). O presente modelo adota uma concepção diferente acerca do papel desse tipo de variável, pois ao considerar o colegiado a partir do conceito de cenário, não se nega a participação dessa variável na causalidade do comportamento jurídico, mas também se assume que outras variáveis, tais como as leis e o histórico de aprendizagem possam interagir de modo significativo. Ou seja, se assume que o contexto é crucial para o estudo dos comportamentos jurídicos, mas não é a única variável antecedente relevante a ser investigada.

Como é possível verificar na Figura 2, especificamente no que concerne ao presente trabalho, existem três tipos de cenário representado por diferentes colegiados onde são tramitados os processos de TCE, esses são: a $1^{\text {a }}$ Câmaras, a $2^{\text {a }}$ Câmaras e o Plenário. Como será melhor detalhado no Estudo 2, a $1^{\mathrm{a}}$ e $2^{\mathrm{a}}$ Câmaras são compostas por quatro integrantes, enquanto que o Plenário é composto por nove (cf., TCU, 2015). Também existem outras diferenças 
qualitativas entre as câmaras e o Plenário, no entanto, tais aspectos serão melhor explorados no Estudo 2.

Antecedentes: Lei. No que se refere a interpretação da função da lei para os comportamentos jurídicos dos operadores da lei em colegiado, as principais contribuições teóricas são oferecidas pela análise comportamental do direito (cf., Aguiar, 2006, 203, 1014). Em termos simples, o autor enfatiza que a interpretação proposta por Skinner (1953), de que as leis tem a função de estímulo discriminativo. Por se tratarem de componentes verbais ou linguísticos, é possível afirmar que quando o indivíduo segue uma determinada lei ou normativo ele está se comportamento em função de um controle instrucional (i.e., comportamento governado por regras). Ou seja, de acordo com essa proposta, a lei constitui uma contingência planejada com o intuito de controlar a frequência de um determinado comportamento, geralmente baixando ou suprimindo a sua frequência (i.e., contingência jurídica).

Aguiar (2006, 2013, 2024) ainda destaca que a lei pode ter diferentes funções para diferentes indivíduos envolvidos no contexto no qual ela se aplica. Nesse sentido, a lei continua tendo função de estímulo discriminativo, no entanto, ela sinaliza que diferentes tipos de comportamentos serão evocados para cada um dos indivíduos envolvidos. Por exemplo, no que se refere aos processos de TCE, o art. 16 da lei 8.443 (TCU, 2002) sinaliza que o ato de desviar recursos públicos será punido. Ou seja, a lei descrita pelo art. 16 da lei orgânica do TCU foi estabelecida para reduzir as infrações cometidas por gestores ou responsáveis por recursos públicos. No entanto, no caso de Ministros e Ministros-substitutos do TCU enquanto relatores de processos de TCE essa mesma lei tem outras funções discriminativas. E uma de suas principais funções é a de estabelecer que uma sanção específica deve ser emitida em função do tipo de ato infracional cometido pelo gestor responsável por recursos públicos (ver Figura 2). 
O conceito de lei e de contingência jurídica apresentado por Aguiar (2006, 2013, 2024) ajuda a identificar as variáveis antecedentes que influenciam o comportamento do operador da lei de modo mais preciso. E ao adotar a premissa do BPM que os estímulos discriminativos (i.e, leis) interagem com variáveis de cenário, tal análise fica potencialmente mais completa e precisa. Pois como será investigado no Estudo 2, é possível verificar que uma mesma sanção, amparada por uma mesma lei, seja aplicada com magnitudes distintas por um mesmo relator de processo para uma mesmo ato infracional. Ou seja, o relator não é um mero aplicador de leis, mas também terá seus comportamentos jurídicos sujeitos a sofrer influência de uma série de variáveis contextuais, de modo que todos esses elementos devem ser comtemplados em uma contingência jurídica.

Histórico de aprendizagem. Em análise do comportamento o conceito de histórico de aprendizagem (ou histórico de condicionamento) pode se referir a qualquer repertório comportamental do indivíduo (cf., Baum, 1999, Moore, 2008). Já de acordo com o BPM proposto por Foxall (1990, 2002, 2010), o conceito de histórico de aprendizagem se refere de modo exclusivo a comportamento de consumo.

Com o intuito de torná-lo mais preciso e relevante para os fenômenos investigados o conceito de histórico de aprendizagem também é definido de modo restrito no presente modelo. Como é possível verificar na Figura 2 esse conceito se refere especificamente a comportamentos jurídicos. Desse modo, ao integrar o conceito de histórico de aprendizagem de comportamentos jurídicos ao modelo explicativo, implica em assumir que diferentes operadores da lei (e.g., relatores de processos de TCE) podem se comportar de modo qualitativamente distinto (i.e., aplicação de sanções) em função das consequências que esse comportamento produziu no passado (reforçadores ou punidores informativos ou utilitários). 
Outra vantagem de empregar o conceito de histórico de aprendizagem é de que esse permite interpretar os resultados empíricos de uma porção significativa de estudos empíricos de análise econômica do direito, que é a literatura que estuda efeitos de ideologia sobre a decisão de magistrados em colegiado (e.g., Epstein et al., 2013, Kastelac, 2007, Kim, 2009, Sisk \& Heise, 2005). Como já foi abordado anteriormente, a ideologia tende a ser classificada em função da origem política do juiz que compõem a suprema corte americana (i.e., Supreme Court), que pode ser democrata ou republicana. Ao analisar esse tipo de literatura, é possível identificar que em grande parte dos casos esse conceito é empregado de modo disposicional. De acordo com Ryle (1949), conceitos disposicionais descrevem regularidades, pois sinalizam condições do tipo SeEntão. Ou seja, esses conceitos descrevem que "se" certas condições estiverem presentes "então" certos comportamentos tendem a ocorrer.

Alguns estudos de análise econômica do direito (e.g., Epstein et al., 2013, Kastelac, 2007, Kim, 2009, Sisk \& Heise, 2005) verificaram a probabilidade de emissão de voto contrário a decisão emitida pelo relator (i.e., dissention) em função do membro do colegiado ter uma ideologia contrária ao relator (e.g., democrata vs. republicano). Baseando-se nisso, uma interpretação do uso do conceito de ideologia empregado nesses estudos a partir de uma lógica disposicional implica na seguinte proposição "Se-Então": "Se" o relator tiver uma ideologia oposta "Então" o membro do colegiado vota discordando. Desse modo, a interpretação de conceitos como ideologia a partir de uma lógica disposicional, permite compreende-los como a descrição de certos padrões de comportamentos em que ocorrem em certas condições (cf., Ryle, 1949). Ou seja, caracterizar um certo magistrado como tendo certo tipo de ideologia, implica em descrever e predizer como esse magistrado tende a se comportar em certas situações. 
Nesse sentido, a interpretação desses conceitos a partir de uma lógica disposicional permite liga-los diretamente ao conceito de histórico de aprendizagem. Ou seja, a ideologia ou outros conceitos afins podem ser interpretados como o resumo de padrões de comportamentos que ocorrem em função de certas variáveis e esses são produto de um histórico de reforçamento diferencial em contextos específicos (e.g., colegiado e lei).

Tal como é possível verificar na Figura 2, no contexto do presente trabalho foram identificadas duas variáveis que podem ser interpretadas a partir do conceito de histórico de aprendizagem com o auxílio do uso de uma lógica disposicional: o cargo do relator, que pode ser de Ministro ou Ministro-substituto; e o cargo anterior do relator, categorizado em político e técnico. Como será investigado e apresentado em detalhe no Estudo 3, essa categorização permite identificar elementos de histórico de aprendizagem de comportamentos jurídicos que podem ser relevantes para a explicação de certas regularidades acerca de diferenças individuais nas sanções estabelecidas pelos relatores em processos de TCE.

Comportamentos jurídicos. Primeiramente, é necessário enfatizar que o presente modelo se baseia em uma premissa essencial acerca da natureza da decisão judicial, que é defendida tanto pela análise econômica do direito (Posner, 1995, 2007) quanto pela análise comportamental do direito (Aguiar, 2006, 2014). Apesar de certas diferenças epistemológicas, essas abordagens basicamente assumem que os comportamentos dos operadores da lei são comportamentos como outros qualquer, e portanto, podem ser objeto de estudo empírico objetivo. Desse modo, é necessário caracterizar os tipos de categorias de comportamentos que podem ser estudas pelo presente modelo, que no caso podem ser divididas em individuais e de grupo, e definir claramente as que serão investigadas nos estudos empíricos posteriores (Estudos 2 e 3$)$. 
Uma das premissas básicas do BPM é que o comportamento ocorre na interseção entre um cenário (i.e., contexto) e um histórico de aprendizagem. Sendo que tal comportamento tem sua ocorrência futura e frequência influenciadas por suas consequências ambientais (cf., Foxall, 1990, 2002, 2010). A princípio, tal premissa se refere ao comportamento do consumidor, mas essa interpretação pode ser empregada de modo análogo aos comportamentos jurídicos em colegiado. Isso é possível pois os comportamentos emitidos por operadores da lei também estão sujeitos a restrições ambientais e contextuais, tais como as leis e o próprio ambiente de colegiado, e também são modelados em função de um histórico de aprendizado específico de seguimento e aplicação de leis.

Conforme é possível verificar na Figura 2, foram delimitados dois grupos de comportamentos: comportamentos do colegiado e comportamentos do relator. No que se refere ao comportamento do colegiado, estão descritos no modelo os votos emitidos pelos membros de um colegiado. Esse é o típico nível de análise empregado em estudos de análise econômica do direito (e.g., Epstein et al., 2011, 2013), e apesar de se referir ao voto emitido por indivíduos em função da decisão do relator, o nível de análise se refere aos padrões de decisão do grupo. Ou seja, o grupo tende a discordar em menor ou maior frequência das decisões do relator em função de determinada variável (etc., composição e tamanho do colegiado, ideologia do relator). Portanto, assim como é o caso de comportamentos individuais, também é possível assumir que esse padrões também estejam sujeitos a sofrer influência de categorias semelhantes de variáveis antecedentes e consequentes.

Já no que concerne aos comportamentos do relator, os estudos de análise econômica do direito se referem as sentenças emitidas por um Juiz (e.g., Epstein et al., 2013). Já no caso específico do presente estudo, o modelo se refere as sanções propostas por Ministros e Ministros- 
substitutos do TCU em casos de TCE. Esse nível de análise, baseado no comportamento do indivíduo, difere da literatura típica e se integra melhor com a proposta da análise do comportamento. No entanto, é necessário destacar que mesmo tendo o foco em investigar decisões acerca de sanções emitidas por Ministros ou Ministros-substitutos a nível individual, a influência do grupo (i.e., colegiado) é uma variável essencial a ser estudada. Como já foi relatado sobre a literatura de análise econômica do direito (e.g., Epstein et al., 2013) e também será abordado no Estudo 2, as decisões dos operadores da lei podem ser influenciadas pelo colegiado no qual ocorrem.

Consequências ambientais. De acordo com os princípios básicos de análise do comportamento (Skinner, 1953) e que também são empregados pela análise econômica do direito (Aguiar, 2014), um comportamento operante (tais como a emissão de sanções ou votos) tem a sua frequência e probabilidade de ocorrência futura em um dado contexto determinado por suas consequências ambientais. Como já foi explicado anteriormente, o BPM proposto por Foxall (1990, 2002, 2010) também assume tal paradigma explicativo, mas propõe a classificação das consequências ambientais produzidas pelo comportamentos em utilitárias e informativas.

Assim como foi demonstrado em uma série de estudos sobre comportamento do consumidor (e.g., Cavalcanti et al., 2013; Foxall, et al., 2006; Oliveira-Castro et al., 2006; Oliveira-Castro et al., 2015, 2016; Oliveira-Castro \& Foxall, 2013), a classificação das consequências ambientais em utilitárias e informativas oferece diversas vantagens preditivas e explicativas. Nesse sentido, adotar tal classificação também pode ser útil para a investigação de comportamentos jurídicos em colegiado por principalmente dois aspectos. Primeiramente, assim como ocorre em estudos sobre comportamento do consumidor, esses conceitos permitem uma classificação qualitativamente mais precisa das consequências ambientais, pois essa é baseada 
em aspectos funcionais relacionados a elementos amplamente presentes nesse tipo de contexto. Ou seja, é possível verificar de modo objetivo se as decisões judiciais em colegiado acerca de determinada lei ocorrem mais em função de aspectos utilitários (i.e., práticos, operacionais) ou informativos (i.e., status, prestígio) dos reforçadores.

Em segundo lugar, a incorporação desses conceitos também permite interpretar e integrar ao presente modelo os resultados obtidos pelos estudos de análise econômica do direito. Em análise econômica do direito (e.g., Esptein et al., 2013; Posner 1995) se assume que ao realizar decisões em colegiado os juízes tendem a maximizar certos fatores tais como: tempo livre, dinheiro, prestígio e status. Esses fatores são descritos em funções de utilidade (ver equação 1), e como será demonstrado a seguir, podem ser classificado como utilitários e informativos. Ou seja, o uso dos conceitos de consequências utilitárias e informativas permite realizar comparações e relações diretas entre estudos de análise econômica do direito e os resultados do estudos empíricos conduzidos no presente trabalho (Estudos 2 e 3) e até mesmo com a literatura de análise do comportamento do consumidor baseada no BPM.

Ainda se baseando no BPM (Foxall, 2010), é necessário enfatizar que um mesmo comportamento produz tanto consequências utilitárias quanto as informativas. Ou seja, essas consequências são simultâneas, e mais de um aspecto utilitário e informativo pode ocorrer em função de um mesmo comportamento (e.g., mais tempo livre, mais dinheiro, mais status). Portanto, esses dois aspectos das consequências ambientais interagem na determinação do comportamento, de modo que um comportamento jurídico (e.g., sanção), na verdade ocorre em função de um conjunto ou pacote de consequências utilitárias e informativas.

Consequências utilitárias. De acordo com Foxall (2010), essas consequências se referem a aspectos físicos e práticos decorrentes do comportamento. Além disso, também são definidas 
como consequências utilitárias, aspectos relacionadas a investimento ou ganho de tempo, ganhos e perdas monetárias e até mesmo esforço. Nesse sentido, o nível utilitário das consequências também serve como uma medida de custo associado a um determinado comportamento. Portanto, partindo dessa interpretação, variáveis previstas em funções de utilidade (cf. Posner, 1995; Epstein et al., 2013) relacionadas ao esforço em revisar uma posição jurídica do relator por ter discordado (i.e., dissention aversion), ganho e gasto de tempo livre e possibilidade de ganhos financeiros além do salário como juiz, podem ser classificados como consequências utilitárias.

Conforme é possível verificar na Figura 2, foram adotadas duas categorias de consequências utilitárias para analisar as sanções estabelecidas pelos relatores em processos de TCE: carga de trabalho e tempo. Essa classificação leva em consideração tanto as funções de utilidade de estudos de análise econômica do direito, quanto as variáveis presentes no contexto de trabalho dos Ministros e Ministros-substitutos do TCU. Como será apresentado em detalhe no Estudo 2, o número de acórdãos, de processos apensados e de duração do processo são exemplos de medidas empregadas para investigar as regularidades acerca das sanções emitidas por relatores de processos de TCE que são derivadas de aspectos utilitários das consequências ambientais.

Consequências informativas. Os aspectos informativos das consequências ambientais estão diretamente relacionados a feedback social decorrentes do comportamento (Foxall, 2010). Esse tipo de variável também é descrita em estudos de análise econômica do direito (e.g., Posner, 1995, Epstein et al., 2013), como sendo relacionadas a fatores que os magistrados buscam maximizar em suas decisões judiciais em colegiado, e geralmente são categorizadas como status, reputação ou relacionamento com os pares. Desse modo é possível observar que existe grande sobreposição o entre o modelo aqui proposto e a análise econômica do direito em relação a essa 
categoria de variáveis. Ou seja, é possível interpretar diretamente as variáveis relacionadas a aspetos sociais em análise econômica do direito como consequências informativas.

Como é possível verificar na Figura 2 e será melhor detalhado no Estudo 2 foram classificadas como consequências informativas aspectos relacionados a repercussão do processo (interna e externa ao TCU) e status social relacionado ao voto ou sanção emitida. Como exemplo de medidas adotadas no presente trabalho que foram derivadas desses critérios, é possível mencionar: o montante analisado e o montante do débito relacionado ao processo de TCE e o cargo ocupado pelo gestor (cargo do gestor) que cometeu o dano ao erário. Por exemplo, é possível considerar que um caso relacionado a um prefeito que cometeu um grande desvio de recursos produza mais repercussão social do que uma infração menos grave cometida por um funcionário público. Ou seja, quanto mais relevante o cargo do gestor e maior for o valor da infração cometida, maior a carga de consequências informativas relacionadas ao processo.

Outras considerações. A despeito de diferenças quanto a aspectos teóricoepistemológicos e quanto ao nível de análise normalmente adotado (grupo vs. individuo), foi possível constatar, que, de modo geral, existe correspondência entre os estudos da análise econômica do direito e de propostas baseadas em princípios operante. O que se verificou é que em ambas as propostas ocorre uma prevalência ou um favorecimento da investigação da influência de variáveis contextuais sobre os comportamentos jurídicos de operadores da lei (e.g., decisão, voto, sanção). Ou seja, se estabelece um contraste com explicações mentalistas baseadas em construtos, como racionalidade, heurísticas ou vieses (cf. Jolls et al., 1998) e também com concepções tradicionais do direito que enfatizam a influência de aspectos normativos sobre o comportamento dos magistrados (cf. Bobbio, 2004). 
Como exemplo dessa sobreposição entre as áreas, é possível destacar alguns pontos da proposta de Posner (1995, 2007) e Epstein et al. (2013) para a análise econômica do direito. Primeiramente, os fatores previstos pelas funções de utilidade relacionados a maximização são altamente dependentes do contexto e mais individualizados, sendo que praticamente não se amparam em variáveis mediacionais internas tais como construtos mentais ou cognitivos. Portanto, é possível concluir que o foco das análises nessa abordagem é mais particular, pois alguns trabalhos da área tendem a abordar grupos específicos de indivíduos com histórico de aprendizagem compartilhado (e.g., juízes de uma certa instância). Também se identifica que alguns desses estudos investigam situações comparáveis, tais como decisões relativas a um tipo de jurisprudência específica (e.g., Boyd et al., 2010; Kim, 2009, Lauderdale \& Clark, 2012).

Em segundo lugar, também é possível constatar que o tipo de análise desenvolvida em trabalhos de análise econômica do direito apresenta considerável aproximação com etapas realizadas durante uma análise funcional baseada em análise do comportamento. Em termos simples, um análise funcional consiste em identificar as variáveis relacionadas à ocorrência de um comportamento, tais como sua forma, contexto (i.e., antecedentes), benefícios (i.e., reforçadores), custos e restrições (cf. Moreira \& Medeiros, 2007), o que se assemelha bastante aos modelos de maximização de utilidade (e.g., Posner, 1995; Epstein et al., 2011, 2013). Ou seja, os dois tipos de trabalho estão basicamente investigando o mesmo tipo de relação entre eventos, e procuram explicações causais em variáveis semelhantes, já que os conceitos de reforço e utilidade apresentam grande sobreposição em suas definições (cf., Herrnstein, 1990; Oliveira-Castro, et al., 2015, 2016). Além disso, vale ressaltar que a análise funcional é tanto o passo inicial quanto uma das bases para discussão de resultados de diversos trabalhos em análise 
do comportamento, inclusive daqueles que discutem a influência das leis na sociedade (e.g., Aguiar, 2013, 2014; Skinner, 1953/2002; Todorov, 2005).

Uma das críticas apresentadas por autores como Aguiar (2006) e Cameron e Kornhauser (2015) a estudos de análise econômica do direito se refere a uma ênfase exagerada aaspectos contextuais, enquanto esses descaracterizam ou não o investigam a função da lei propriamente dita. Esse tipo de postura que pode ser descrita como contextualista ou atitudinalista é identificada em uma porção representativa da literatura de análise econômica do direito, onde o tipo de modelo proposto por autores como Posner $(1995,2007)$ e Epstein et al. (2013) é um dos mais dominantes.

Mais especificamente, Cameron e Kornhauser (2015) argumentam que as pesquisas empíricas sobre decisão de magistrados devem localizar casos e processos analisados, em função de identifica-los de modo qualitativamente mais preciso e representativo com a prática jurídica de fato. Desse modo, a simples análise de elementos presentes no contexto sem a identificação do contexto específico pode implicar em estudos com resultados empíricos com pouca validade ecológica. Ou seja, para os autores, também se faz necessário analisar a lei ou jurisprudência relacionada aos casos, e de preferência analisar em conjunto casos que possuam equivalência quanto as variáveis essenciais que os compõem. Desse modo, a classificação pelo presente modelo (ver Figura 2) apresenta potencial de classificação de casos afins de modo mais preciso e menos arbitrário do que apenas em termos de sua jurisprudência, pois esse se baseia em elementos funcionais das variáveis contextuais antecedentes e consequentes.

Outra característica central do presente modelo está em interpretar a função das leis enquanto variável antecedente, e tal como proposto por (Aguiar, 2006, 2014), na maior parte dos casos ela possui uma função de estímulo discriminativo distinto para os diferentes operadores da 
lei. Portanto, interpretar o papel da lei a partir de critérios funcionais operantes, em que essa interage diretamente com elementos do contexto judicial e processual pode ajudar a produzir resultados empíricos mais bem ancorados com a prática jurídica real. Ou seja, passa a ser possível verificar de modo mais confiável se as contingências jurídicas planejadas no texto da lei ou normativo (cf. Aguiar, 2006, 2014) interagem com variáveis contextuais relativas a decisão judicial, tais como o cenário e as consequências utilitárias e informativas, influenciam os comportamentos jurídicos de operadores da lei.

\section{Estudo 2}

O Estudo 2 teve o objetivo de investigar como variáveis relacionadas a características do processo de TCE, tais como montante do débito, motivo de instauração e cargo do gestor que cometeu a infração podem influenciar as decisões dos relatores em processos de TCE em função do colegiado no qual a decisão foi submetida ao voto dos pares. Mas especificamente, o presente estudo verificou como as características do processo interagem com do colegiado onde o processo foi tramitado ( $1^{\mathrm{a}}$ Câmara, $2^{\mathrm{a}}$ Câmara ou Plenário) para influenciar decisões do relator, que nesse contexto representam as sanções que foram por ele propostas (e.g., multa ou inabilitação).

Baseando-se no modelo econômico-comportamental operante para decisões em colegiado proposto no Estudo 1 (ver Figura 2), todos os grupos de variáveis serão investigadas quanto a sua influência nos comportamentos do relator (i.e., comportamentos jurídicos). No entanto, o foco das investigações estarão nas diferenças em decisões em função do colegiado no qual ocorreu a decisão, que foi interpretado como uma variável de cenário. Ou seja, antecedentes como a lei (TCE) e o histórico de aprendizagem serão inseridos de modo estável nos modelos de análise, enquanto se verifica diferenças entre os três tipos de colegiado. 
Durante o processo de TCE, cabe ao relator, que pode ser um Ministro ou Ministrosubstituto (cf. TCU, 2015), elaborar uma proposta a ser avaliada pelo colegiado de decisão acerca do caso. Nessa decisão, estão descritas as sanções propostas para o responsável por contas irregulares (i.e., acórdão de decisão). A partir disso, essa proposta será submetida a votação em um dos colegiados, e uma vez que seja verificada a maioria entre os pares, a sanção é aceita, publicada e executada. Ou seja, na medida em que a decisão foi efetivada por meio de votação, essa pode ser considerada uma decisão em colegiado, no entanto, existe um indivíduo central dentro desse grupo (relator) que na verdade submete a sua proposta de decisão para aprovação de seus pares.

Desse modo, o presente trabalho difere de estudos frequentemente conduzidos em análise econômica do direito (e.g., Epstein et al., 2011, 2013). Nesses estudos, são analisados quase que exclusivamente os votos que cada membro do colegiado emitiu em função da decisão do relator (contra ou a favor), enquanto que no presente trabalho o foco foi na proposta de decisão do relator, verificando características específicas acerca da sanções propostas por ele. Ou seja, o presente trabalho se diferencia dessa tradicional linha de pesquisa em análise econômica do direito no sentido adotar um tipo de variável dependente distinta. No entanto, apresenta sobreposição com essa literatura pelo tipo de variável investigada (características do processo) e o nível de análise, que é o contexto decisão em colegiado.

Com intuito de oferecer uma melhor compreensão acerca dos fenômenos estudados nesse trabalho, a sessão seguinte descreve os detalhes relevantes ao contexto profissional de Ministros e Ministros-substitutos do TCU. Também estão descritos na próxima seção detalhes acerca da dinâmica das decisões de colegiado e das características mais relevantes do processo de Tomada de Contas Especial (TCE), que foi o tipo de processo analisado nos Estudos 2 e 3. 


\section{O Tribunal de Contas da União}

O TCU é um tribunal administrativo que tem como tarefa primária a fiscalização e o julgamento de administradores públicos quanto ao uso de contas e bens federais, ou seja, ele é um órgão de controle externo com função fiscalizadora e de poder sancionatório. Ao TCU se atribuem as características de decisões colegiadas, e no que diz respeito a sua natureza jurídica, ele é autônomo e independente. (Tribunal de Contas da União [TCU], 2002, 2015)

Dentre as atribuições devidas de sua competência, estão as de julgar as contas dos administradores e demais responsáveis por dinheiros, bens e valores públicos, assim como as contas daqueles responsáveis por irregularidades com consequente dano ao erário. Também é competência do TCU aplicar as devidas sanções, assinar prazo para a adoção das providências solicitadas, e até mesmo sustar atos, que envolve interromper processos de licitação caso sejam identificadas irregularidades (TCU, 2002, 2015).

Também é importante salientar que as decisões deferidas pelo TCU podem ser revistas pelo judiciário no que compete a legalidade e formalidade da decisão. No entanto, o judiciário não analisa ou revê questões relacionadas ao mérito das decisões do TCU, e nesse sentido, se enfatiza que o órgão possui autonomia em suas ações (TCU, 2002, 2015).

O TCU exerce a sua fiscalização nos campos de natureza contábil, financeira, orçamentária, patrimonial e operacional, avaliando os aspectos da legalidade, legitimidade, economicidade, além das aplicações de subvenções e renúncias de receita. Esses processos podem ser estabelecidos por iniciativa própria do TCU ou pelo requerimento do Poder Legislativo (TCU, 2002, 2015).

No caso de requerimentos de instauração de fiscalização ou processos pelo TCU pela iniciativa do Poder Legislativo, essa se dará por solicitação do Congresso Nacional ou de suas 
Comissões Técnicas ou Comissões de Inquérito. Esses requerimentos ocorrerão em função da execução de auditorias ou inspeções nas unidades administrativas dos três Poderes e dos demais órgãos e entidades sob sua jurisdição, tais como autarquias e fundações, agências reguladoras, empresas públicas, contas nacionais das empresas supranacionais, transferência de recursos a estados e municípios (exceto transferências constitucionais), entidades privadas que recebam recursos, serviços sociais autônomos, entidades de fiscalização profissional que arrecadam e gerenciam contribuições parafiscais, como por exemplo, o fundo de garantia de trabalhadores (TCU, 2002, 2015).

No que concerne a composição do TCU, seu quadro regular de funcionários é dividido em diversos cargos e atribuições, tais como administrativos, consultores, analistas e diretores. No entanto, as ações e decisões mais importantes realizadas pelo tribunal ocorrem em colegiado, que é composto por um grupo de nove Ministros e quatro Ministros-substitutos. Esses membros são escolhidos dentro as seguintes condições: nacionalidade brasileira, idade entre 35 e 65 anos e dotados de idoneidade. Também é requerido que tenham conhecimentos jurídicos, contábeis, econômicos, financeiros e de administração pública, e que possuam no mínimo 10 anos de exercício em funções que exijam tais competências (TCU, 2002, 2015).

Um terço desses membros é escolhido pelo Presidente da República com aprovação do Senado Federal, enquanto dois terços são de livre escolha do Congresso Nacional, sendo que todos são nomeados pelo Presidente da República. No que se refere aos Ministros-substitutos, esses devem atender os mesmo critérios estabelecidos para os Ministros, contudo, também devem passar por um processo seletivo de concurso público. As garantias previstas no art. 95 da Constituição Federal conferem a estes membros vitaliciedade no cargo, inamovibilidade e irredutibilidade de vencimentos ou subsídios (TCU, 2002, 2015). 
Quanto a sua organização, órgãos que compõem o TCU são: o Plenário, que é composto pelas duas Câmaras e pelo Presidente, sendo esse a sua instância máxima; a $1^{\circ}$ Câmara e a $2^{\circ}$ Câmara, e cada uma delas composta por quatro ministros, além de dois Ministros-substitutos. O Tribunal também é composto por Comissões, que podem ser permanentes ou temporárias, além da Corregedoria (TCU, 2002, 2015).

O Presidente e o Vice-Presidente do Tribunal são eleitos por seus pares para mandato de um ano civil, com possibilidade de uma reeleição. A presidência de uma das Câmaras é designada ao Vice-Presidente e da outra ao Ministro mais antigo. Eles atuam em suas respectivas Câmaras, relatando processos e votando em todas as deliberações do Colegiado. No caso de empate de votos durante uma deliberação, o processo é submetido ao Plenário, que é composto por nove Ministros incluindo o Presidente do TCU (TCU, 2002, 2015).

Em âmbito dos processos, o TCU elabora acórdãos que são compostos por um relatório com dados essenciais, tais como um resumo dos fatos relevantes ao processo, os votos emitidos por cada ministro, assim como a decisão final do colegiado (sanção). Também se salienta que apesar de estarem envolvidos nos processos em cada uma das Câmaras no qual está lotado, os Ministros-substitutos só têm direito de voto no caso de estarem atuando como suplente de algum Ministro em virtude de algum impedimento (TCU, 2002, 2015).

\section{O processo de Tomada de Contas Especial}

De acordo com o art. 17 do Regimento Interno do TCU (TCU, 2015), dentre as competências das Câmaras, estão as de deliberar sobre processos de tomada de contas, inclusive de Tomada de Contas Especial (TCE). No que se refere a tomada de contas, essa é instaurada uma vez que se constate a omissão do administrador, responsável ou gestor público no dever de 
prestar contas da aplicação de recursos repassados pela união, justamente com o intuito de verificar se ocorreram irregularidades.

Já a TCE, constitui uma das principais atividades administrativas do TCU, e esse tipo de processo é instaurado no caso de se constatar dano ao erário, ou seja, se houve dano ao conjunto de bens e recursos financeiros que o governo dispõe para administrar o país. Portanto, esse dano se verifica em casos nos quais o patrimônio ou recursos públicos tenham sido empregados de maneira irregular, como por exemplo se verifica no desvio de verbas públicas. Desse modo, a TCE tem como objetivo apurar os fatos, identificar os responsáveis e quantificar o valor do dano ao erário, para que ele seja restituído de modo mais imediato possível (Controladoria-Geral da União [CGU], 2013).

Também é necessário frisar que o processo de TCE só é instaurado no caso do órgão público, entidade ou unidade administrativa onde ocorreu a irregularidade já terem tomado todas as medidas administrativas possíveis para recuperar o valor relativo ao dano ao erário. Ou seja, se tais medidas administrativas forem bem sucedidas em sanear o prejuízo, não é constatado dano ao erário. Portanto, o processo de TCE será levado adiante apenas nos casos nos quais as medidas administrativas implementadas pelo órgão competente não obtiverem o ressarcimento do prejuízo. Nesses casos, a autoridade administrativa competente deve agir pela instauração do processo assim que constatado indício de irregularidade, pois essa é passível de ser julgada por responsabilidade solidária caso não o faça (CGU, 2013).

Outra questão que também deve ser levada em consideração antes da instauração do processo de TCE é o valor do dano. Em casos nos quais o dano ao erário for inferior a $\mathrm{R} \$$ 75.000,00 ocorrerá a dispensa da TCE, de modo que o prejuízo deverá ser reparado por meio de processos internos administrativos do órgão competente. Esse valor mínimo se refere ao 
montante total do processo, e não a partes relativas ao dano causado por um indivíduo no caso de processos com múltiplos responsáveis. Portanto, se uma pessoa lesou o erário em R $\$ 10,000,00$, mas o montante total do dano do caso no qual ela está envolvida é de, por exemplo, $\mathrm{R} \$$ 100,000,00, pois existem outros responsáveis que atuaram de forma conjunta, o processo de TCE será instaurado, e essa pessoa será julgada como um dos responsáveis pelo TCU. Também pode ocorrer a dispensa da TCE no caso de já haver transcorrido um prazo de 10 anos entre a data provável do dano e a primeira notificação dos responsáveis pelo órgão competente (CGU, 2013; TCU, 2015).

Com a instauração do processo de TCE, durante o curso do julgamento, serão analisados os documentos fornecidos pelos responsáveis pelas contas para determinar se de fato ocorreram irregularidades na administração de recursos públicos, e, a partir disso isso, verificar se houve dano ao erário. De acordo com o art. 214 do Regimento Interno do TCU (TCU, 2015) caso as contas sejam julgadas como regulares, ao responsável não será imputada nenhuma cobrança ou débito, e esse receberá um certificado de quitação plena com o erário (TCU, 2002, 2015).

De modo mais específico, conforme descreve o art. 16 da Lei Orgânica (TCU, 2002) uma vez analisadas, uma conta pública pode ser classificada como: (a) regular, (b) regular com ressalvas ou (c) irregular. Conforme descrito no inciso III do art. 16 (TCU, 2002, pp.7-8), para que uma conta seja julgada como irregular (identificado dano ao erário), existem quatro tipos de ato infracional (alíneas “a”, "b", “c” e "d"):

“Art. 16. As contas serão julgadas:

I - regulares, quando expressarem, de forma clara e objetiva, a exatidão dos demonstrativos contábeis, a legalidade, a legitimidade e a economicidade dos atos de gestão do responsável; 
II - regulares com ressalva, quando evidenciarem impropriedade ou qualquer outra falta de natureza formal de que não resulte dano ao Erário;

III - irregulares, quando comprovada qualquer das seguintes ocorrências:

a) omissão no dever de prestar contas;

b) prática de ato de gestão ilegal, ilegítimo, antieconômico, ou infração à norma legal ou regulamentar de natureza contábil, financeira, orçamentária, operacional ou patrimonial;

c) dano ao Erário decorrente de ato de gestão ilegítimo ao antieconômico;

d) desfalque ou desvio de dinheiros, bens ou valores públicos.

De acordo com o art. 202 do Regimento Interno do TCU (TCU, 2015), uma vez que tenha sido constatado o dano ao erário pelo colegiado, existem duas sanções previstas para os responsáveis, que é o ressarcimento do débito e/ou a multa, que são determinadas pelos artigos 56 e 57 da Lei Orgânica (TCU, 2002). Os responsáveis por contas irregulares podem tanto ser pessoas físicas, como Governadores, Prefeitos e funcionários públicos, quanto pessoas jurídicas, como no caso de empresas prestadoras de serviço. A responsabilidade por contas irregulares também pode ser definida como individual ou solidária, de modo que uma responsabilidade solidária é verificada quando mais de um agente atuou para causar o dano ao erário (CGU, 2013).

No que se refere ao débito, de acordo com o art. 10 da Lei Orgânica do TCU (TCU, 2002) esse se refere ao ressarcimento integral do valor que foi desviado ou empregado de maneira irregular, com atualização monetária desde a data em que ocorreu a infração. Quando um débito não puder ser verificado precisamente, deverá ser feita uma estimativa do dano.

Já no caso das multas, conforme especificam os artigos 267 e 268 do Regimento Interno do TCU (TCU, 2015), estas devem ser aplicadas no caso da constatação de débito. Ainda de 
acordo com os artigos 267 e 268, os valores dessas sanções são determinados com base nas sanções previstas pelos Artigos 57 e 58 da Lei n 8.443, de 1992 (TCU, 2002, pp. 14-15), conforme pode ser verificado abaixo:

Art. 57. Quando o responsável for julgado em débito, poderá ainda o Tribunal aplicar-lhe multa de até cem por cento do valor atualizado do dano causado ao Erário.

Art. 58. O Tribunal poderá aplicar multa de Cr\$42.000.000,00 (quarenta e dois milhões de cruzeiros), ou valor equivalente em outra moeda que venha a ser adotada como moeda nacional, aos responsáveis por:

I - contas julgadas irregulares de que não resulte débito, nos termos do parágrafo único do art. 19 desta Lei;

II - ato praticado com grave infração à norma legal ou regulamentar de natureza contábil, financeira, orçamentária, operacional e patrimonial;

III - ato de gestão ilegítimo ou antieconômico de que resulte injustificado dano ao Erário; IV - não atendimento, no prazo fixado, sem causa justificada, a diligência do Relator ou a decisão do Tribunal;

V - obstrução ao livre exercício das inspeções e auditorias determinadas;

VI - sonegação de processo, documento ou informação, em inspeções ou auditorias realizadas pelo Tribunal;

VII - reincidência no descumprimento de determinação do Tribunal.

Por fim, o último tipo de sanção imposta pelo TCU em função da identificação de contas irregulares de gestores ou responsáveis por fundos públicos é a inabilitação para o exercício de cargo ou função na administração (art. 60 da lei Orgânica do TCU). Esse tipo de sanção deve ser aplicada em casos de infração grave em que houve dano ao erário, e deve ser definida por 
unanimidade dos membros do colegiado. Conforme está previsto no art. 270 do Regimento Interno (TCU, 2015): “o responsável ficará inabilitado, por um período que variará de cinco a oito anos, para o exercício de cargo em comissão ou função de confiança no âmbito da administração pública federal, nos termos do art. 60” (p. 49).

Por fim, baseando-se no Regimento Interno e Lei orgânica do TCU (TCU, 2002, 2015), e no que foi exposto previamente, é possível sumarizar as sanções da seguinte forma: (1) débito, restituir o valor do dano ao erário; (2) multa prevista no art. 57, é aplicada em casos de constatação de dano ao erário, e pode ser fixada em até $100 \%$ do valor do débito; (3) multa prevista no art. 58, é aplicada em casos de omissões relativas a prestação de contas, mas que não tenha ocorrido dano ao erário diretamente, seu valor é fixo e estabelecido pelo colegiado; (4) inabilitação, sanção aplicada em casos de infrações graves que envolvam dano ao erário.

\section{Método}

Banco de dados. Uma das atribuições do TCU consiste em elaborar uma lista a cada dois anos com os responsáveis por contas irregulares que foram julgados em processos de TCE para enviar ao Tribunal Superior Eleitoral (TSE). Essa lista é enviada antes de cada ano eleitoral com indivíduos que tiveram processos tramitados em julgado em até oito anos antes das eleições correntes. Tal atribuição é realizada com base na Lei 9.504/1997 (Lei Eleitoral) e na Lei Complementar 135/2010 (Lei da Ficha Limpa), pois o TSE utiliza essa lista para determinar que tais indivíduos sejam considerados inelegíveis por estarem com pendências com o governo.

A lista empregada no presente trabalho foi elaborada pelo TCU para as eleições de 2014. O presente documento foi organizado em uma planilha com 10,512 casos e contém algumas informações básicas sobre os processos de TCE, tais como nome: nome do responsável, $\mathrm{CPF}$, montante analisado e data em que o processo foi tramitado em julgado. $\mathrm{O}$ arquivo também 
contém um link que abre uma página de internet que dá acesso a todos os acórdãos relativos a cada processo assim como um sumário. A partir disso, foi possível analisar todos os acórdãos relacionados a um dado processo de TCE acerca de suas características e decisões. Desse modo, como será melhor descrito a seguir, diversas informações foram extraídas com o intuito de analisar as decisões de Ministros e Ministros-substitutos enquanto relatores de processos de TCE.

Materiais. Os materiais empregados nesse estudo foram a lista de responsáveis por contas irregulares elaborada pelo TCU para o TSE para as eleições de 2014 e os acórdãos relativos aos processos contidos nessa lista. Também foram empregados os programas Excel $2013^{\circledR}$ e SPSS $20^{\circledR}$ para organizar e analisar estatisticamente os dados obtidos.

Procedimento. O presente estudo empregou um banco de dados semelhante ao coletado para o estudo de Oliveira (2016) que contém informações a diversas variáveis relevantes, tais como montante do débito, tipo ato infracional (motivo de instauração) e valores das sanções emitidas para os processos (e.g., multa 57). No entanto, outras variáveis foram extraídas de cada um dos processos analisados com o intuito de verificar regularidades relativas a decisões em colegiado de Ministros e Ministros-substitutos do TCU. Por exemplo: o colegiado em que ocorreu a decisão, o cargo do relator, o número de acórdãos e processos apensados por caso, o tipo de cargo anteriormente ocupado pelo relator antes de ser nomeado como Ministro ou Ministro-substituto, dentre outras.

Desse modo, a composição do banco de dados, seguiu os parâmetros estabelecidos por Oliveira (2016) que consistiu na extração de duas amostras representativas da lista com 10,572 casos de indivíduos responsáveis por contas irregulares. Para determinar o tamanho de uma 
amostra representativa foi estimado um intervalo de confiança de $95 \%$ e erro amostral de $5 \%$. Desse modo, o cálculo amostral seguiu os parâmetros descritos na equação abaixo:

$$
n=\frac{N \cdot Z^{2} \cdot p \cdot(1-p)}{Z^{2} \cdot p \cdot(1-p)+e^{2} \cdot(N-1)}
$$

Portanto, nesse modelo, $n=$ amostra calculada; $N=$ população; $Z$ = variável normal padronizada associada ao nível de confiança; $p$ - verdadeira probabilidade do evento; $e=$ erro amostral. Desse modo, A partir desse modelo, foram extraídas de modo aleatório duas amostras com 371 processos de TCE cada. O uso de duas amostras foi adotado no intuito de aumentar a representatividade e confiabilidade dos dados obtidos e posteriormente analisados. Também é necessário salientar que durante a seleção aleatória dos processos, foram retirados de uma das amostras aqueles casos que fossem repetidos nas duas amostras. A partir disso, foi realizado uma seleção aleatória de outro caso, e desde que esse não fosse novamente repetido, ele era incluído na amostra.

Durante a extração dos dados, foram analisados o sumário do processo, acórdãos de decisão e de recursos para extrair e quantificar as variáveis relacionadas aos processos de TCE. Também é necessário enfatizar que as variáveis coletadas para os processos de TCE levaram em consideração apenas os acórdãos emitidos entre a data de instauração e a data de transito em julgado do processo. Isso foi necessário pois alguns dos processos continuam tendo acórdãos publicados após a sua decisão final, e geralmente tais acórdãos se referem a decisões que declararam a quitação do débito ou multa atribuída ao gestor ou responsável. Desse modo, tais acórdãos não foram analisados, pois não contém informações relevantes quanto as variáveis que podem influenciar a decisão dos relatores em colegiado. 
As principais variáveis empregadas em análises descritivas e inferenciais nos Estudos 2 e

3 estão definidas de modo operacional na Tabela 1. Foram adotados nomes resumidos para algumas variáveis com intuito de facilitar a sua referência no texto (e.g., multa 57, \% multa 58).

Tabela 1

Sumário das definições operacionais das principais variáveis investigadas nos estudos 2 e 3

Variável Definição operacional

Acórdãos total

Cargo do gestor (responsável)

Duração do processo

Montante analisado

Montante do débito

Motivo de instauração

Processos apensados

Colegiado

Cargo do relator

Cargo anterior do relator

Multa 57

$\%$ Multa 57

Multa 58

$\%$ Multa 58

Inabilitação
Número de acórdãos emitidos para um processo de TCE. Incluem acórdãos de decisão, relação, recursos e embargos.

Cargo ocupado pelo gestor ou responsável por recursos públicos que foi julgado por contas irregulares.

Duração medida em anos dos processos de TCE. Medida a partir da data de instauração até a data de transito em julgado

Valor total de recursos públicos envolvidos no processo de TCE. Geralmente uma parte desse montante se converte em débito

Valor do dano ao erário aferido no processo de TCE. Pode se relacionar a desvios, desfalques ou uso inapropriado de recursos.

Tipo de infração cometida pelo gestor (baseadas no Inciso III do art. 16) Categorias: alíneas "a", "b", "c", "d" e "mais de um ato"

Números de processos apensados ao processo de TCE que está sendo analisado. Tais processos são julgados em conjunto

Identificação do colegiado onde ocorreu a decisão. Divide-se em três categorias: Plenário, $1^{\mathrm{a}}$ Câmara e $2^{\mathrm{a}}$ Câmara

Cargo do relator do processo de TCE. Divide-se em duas categorias: Ministro ou Ministro-substituto

Tipo de cargo anterior a nomeação do relator como Ministro ou Ministro-substituto. Duas categorias: Político ou Técnico

Valor absoluto da Multa prevista pelo art. 57 da lei orgânica do TCU. Pode se referir até $100 \%$ do valor do débito.

Valor percentual da multa prevista pelo art. 57 em função do valor do débito identificado no processo de TCE

Valor da multa prevista pelo art. 58. É determinado a cada ano e pode variar de $5 \%$ a $95 \%$ de um valor máximo estabelecido

Valor percentual da multa prevista pelo art. 58 determinada pelo relator em processo de TCE

Impossibilidade para exercer cargo em comissão ou função de confiança no âmbito da administração pública 
A tabela está organizada agrupando as variáveis relacionadas a (1) características do processo: acórdãos total, cargo do responsável, duração do processo, montante analisado, montante do débito, motivo de instauração, processos apensados; (2) nível de análise: colegiado, cargo do relator e cargo anterior do relator; e por fim (3) sanções: multa 57, \% multa 57, multa 58, \% multa 58 e inabilitação. O Grupo 1 de variáveis representam variáveis independentes, o Grupo 2 representam níveis de análise (que também são tipos de VI), enquanto o Grupo 3 (sanções) foram interpretadas como variáveis dependentes relacionadas as decisões dos relatores.

Análise de Dados. Com intuito de verificar regularidades sobre as decisões dos Ministros e Ministros-substitutos em processos de TCE, o presente estudo adotou como foco de análise o relator do processo. Conforme as análises identificaram é comum que os processos de TCE mudem de relator $(M=2,25 ;$ Mínimo $=1 ;$ Máximo $=8$; considerando a amostra completa $)$. Alguns dos motivos relacionados a essas mudanças na relatoria podem ser aposentadoria, questões de saúde, pedidos de recurso da decisão anterior ou em função do relator do processo ter sido nomeado Presidente do TCU (cf. Regimento Interno, TCU, 2015).

Levando em consideração tais aspectos, no contexto do presente estudo foi definido como relator do processo, aquele Ministro ou Ministro-substituto que emitiu o primeiro acórdão de decisão. Nesse acórdão estão descritas as sanções que foram estabelecidas em função do ato ou atos infracionais cometidos pelos responsáveis por fundos públicos e o valor do dano ao erário. Eventualmente tais decisões podem ser alteradas, mas como também se verificou em análise prévia, a frequência de acórdãos de recursos foi relativamente baixa (239 em 742 casos). Além disso, também foram verificados que os acórdãos de recurso que concederam provimento ao pedido do responsável foram ainda menos frequentes (apenas 46 casos de 239), e geralmente tais acórdãos não modificam o tipo e nem o valor da sanção. 
Para investigar as decisões em colegiado em processos de TCE em função do tipo de colegiado em que o processo ocorreu (1 $1^{\mathrm{a}}$ Câmara, $2^{\mathrm{a}}$ Câmara ou Plenário) foram conduzidas análises descritivas (frequência e distribuição) para diversas variáveis relacionadas aos processos (ver Tabela 1). Por fim, também foram conduzidas análises inferenciais, que tiveram o intuito de verificar se existem diferenças estatisticamente significantes entre grupos (i.e., tipo de colegiado) para cada uma das variáveis (ANOVA), e de verificar o efeito de tais variáveis sobre as decisões dos relatores (sanções) a partir de regressões múltiplas.

\section{Resultados}

Os resultados para as análises descritivas e inferenciais referentes ao nível de análise de colegiado estão descritas na presente seção. Primeiramente serão apresentadas as análises descritivas, e estas foram divididas em quatro tipos: (1) composição do colegiado, (2) distribuição dos processos de TCE, (3) variáveis relacionadas aos processos de TCE e (4) tipo de sanção. Por fim, foram apresentadas as análises inferenciais, divididas em (a) análises de variância e (b) regressões múltiplas.

Composição dos colegiados. Na Tabela 2 estão as informações relacionadas ao número de relatores dos processos de TCE analisados nas três amostras empregadas no estudo. Como já foi enfatizado anteriormente, a composição do colegiado é de nove Ministros e quatro Ministrossubstitutos, no entanto, como os dados analisados compreendem casos que datam de cerca de 20 anos atrás, a composição do colegiado apresentou variações ao longo do tempo. Desse modo, dos 19 relatores identificados nas análises, 15 são Ministros e 4 Ministros-substitutos, e desses 15 Ministros 6 se encontram atualmente aposentados. Também foi possível identificar que o número total de relatores nos três colegiados considerando as três amostras foi semelhante. 
Tabela 2

Frequência (e porcentagem) de relatores responsáveis por acórdãos de decisão de processos de TCE tramitados em cada um dos colegiados em todas as amostras

\begin{tabular}{lccc}
\hline Colegiado & Amostra $^{a}$ & Amostra $^{b}$ & Amostra total $^{c}$ \\
\hline $1^{\text {a }}$ Câmara & 16 & 16 & 18 \\
& $(34,8)$ & $(36,4)$ & $(36,7)$ \\
$2^{\text {a Câmara }}$ & 15 & 14 & 15 \\
Plenário & $(32,6)$ & $(31,8)$ & $(30,6)$ \\
& 15 & 14 & 16 \\
Relatores total $^{d}$ & $(32,6)$ & $(31,8)$ & $(32,7)$ \\
\hline
\end{tabular}

Nota. ${ }^{a} N=371 ;{ }^{b} N=371 ;{ }^{c} N=742 .{ }^{d}$ Número de relatores que não se repetem considerando a amostra.

Distribuição dos processos de TCE. A Tabela 3 apresenta descreve o número processos de TCE que ocorreu em cada um dos colegiados. Portanto, essa tabela indica a distribuição das amostras entre os três grupos empregados nesse nível de análise. Os resultados indicam que o número de processos que ocorreram nas duas Câmaras é bem próximo nas três amostras. Quanto ao Plenário, esse tende a ter apenas a metade de processos de TCE em comparação cada uma das duas Câmaras, correspondendo em torno de $19 \%$ do total de processos considerando as três amostras.

Variáveis relacionadas aos processos de TCE. As análises descritivas nessa seção se referem a variáveis que podem ser interpretadas como variáveis independentes, e como variáveis dependentes (sanções) relacionadas aos processos de TCE. A Tabela 4 descreve o número de processos de TCE para os cargos ocupados pelo gestores ou responsáveis por recursos públicos que cometeram infrações (cargo do gestor). 
Tabela 3

Frequência (e porcentagem) de processos de TCE tramitados em cada um dos colegiados em todas as amostras

\begin{tabular}{lccc}
\hline Colegiado & Amostra 1 & Amostra 2 & Amostra total \\
\hline $1^{\text {a }}$ Câmara & 151 & 134 & 285 \\
& $(40,7)$ & $(64,2)$ & $(38,4)$ \\
$2^{\text {a }}$ Câmara & 143 & 169 & 312 \\
& $(38,5)$ & $(45,6)$ & $(42)$ \\
Plenário & 48 & 68 & 145 \\
& $(20,8)$ & $(18,3)$ & $(19,5)$ \\
\hline \multirow{2}{*}{ Total } & 371 & 371 & 742 \\
& $(100)$ & $(100)$ & $(100)$ \\
\hline
\end{tabular}

Nota. $N=$ Amostra 1: 371; Amostra 2: 371; Amostra total: 742.

A categoria com a maior frequência de casos foi a de Prefeitos ou Secretários. Enquanto a que teve a menor frequência foi a categoria outros cargos, que compreende cargos como, bolsistas, tesoureiros e funcionários públicos. Tais tendências foram verificadas em todas as amostras e colegiados.

Também foi analisada a distribuição de processos de TCE por unidade federativa. No entanto, para apresentar dados mais concisos, esses foram agregados por região do Brasil. A Tabela 5 contém essas informações, e indica que em todas as amostras a região com o maior número de casos de TCE foi a Nordeste, enquanto que a região Sul apresentou um menor número de casos. Especificamente no que concerne as unidades federativas, os estados com o maior número de processos por colegiado em cada amostra foram: $1^{\text {a }}$ Câmara, São Paulo (amostra 1 e total) e Maranhão (amostra2); 2ª̂mara, Maranhão (nas três amostras); Plenário, Maranhão (nas três amostras). 
Tabela 4

Frequência (e porcentagem) de processos de TCE em função do cargo do gestor em todos colegiados e amostras

\begin{tabular}{|c|c|c|c|c|c|c|c|c|c|}
\hline \multirow[b]{2}{*}{$\begin{array}{l}\text { Cargo do } \\
\text { responsável }\end{array}$} & \multicolumn{3}{|c|}{$1^{\text {a }}$ Câmara } & \multicolumn{3}{|c|}{$2^{a}$ Câmara } & \multicolumn{3}{|c|}{ Plenário } \\
\hline & $\begin{array}{c}\text { Amostra } \\
1\end{array}$ & $\begin{array}{c}\text { Amostra } \\
2\end{array}$ & $\begin{array}{c}\text { Amostra } \\
\text { total }\end{array}$ & $\begin{array}{c}\text { Amostra } \\
1\end{array}$ & $\begin{array}{c}\text { Amostra } \\
2\end{array}$ & $\begin{array}{c}\text { Amostra } \\
\text { total }\end{array}$ & $\begin{array}{c}\text { Amostra } \\
1\end{array}$ & $\begin{array}{c}\text { Amostra } \\
2\end{array}$ & $\begin{array}{c}\text { Amostra } \\
\text { total }\end{array}$ \\
\hline Prefeito ou & 80 & 55 & 135 & 85 & 75 & 160 & 20 & 39 & 59 \\
\hline Secretário & (53) & (41) & $(47,4)$ & $(59,4)$ & $(44,4)$ & $(51,3)$ & (26) & $(57,4)$ & $(40,7)$ \\
\hline \multirow{2}{*}{$\begin{array}{l}\text { Presidente } \\
\text { ou Diretor }\end{array}$} & 28 & 40 & 68 & 18 & 34 & 52 & 16 & 7 & 23 \\
\hline & $(18,5)$ & $(29,9)$ & $(23,9)$ & $(12,6)$ & $(20,1)$ & $(16,7)$ & $(20,8)$ & $(10,3)$ & $(15,9)$ \\
\hline \multirow{2}{*}{$\begin{array}{l}\text { Outros } \\
\text { cargos }\end{array}$} & 26 & 19 & 45 & 25 & 39 & 64 & 21 & 14 & 35 \\
\hline & $(17,2)$ & $(14,2)$ & $(15,8)$ & $(17,5)$ & $(23,1)$ & $(20,5)$ & $(27,3)$ & $(20,6)$ & $(24,1)$ \\
\hline \multirow{2}{*}{$\begin{array}{l}\text { Dados } \\
\text { faltantes }\end{array}$} & 17 & 20 & 37 & 15 & 21 & 36 & 20 & 8 & 28 \\
\hline & $(11,3)$ & $(14,9)$ & (13) & $(10,5)$ & $(12,4)$ & $(11,5)$ & (26) & $(11,8)$ & $(19,3)$ \\
\hline \multirow{2}{*}{ Total } & 151 & 134 & 285 & 143 & 169 & 312 & 77 & 68 & 145 \\
\hline & (100) & (100) & (100) & $(100)$ & (100) & (100) & (100) & (100) & (100) \\
\hline
\end{tabular}

Nota. ${ }^{a} N=$ Amostra 1: 371; Amostra 2: 371; Amostra total: $742 .{ }^{b}$ Dados faltantes se referem tanto a ausência de informações disponível nos acórdãos de decisão quanto a casos sigilosos

Na Tabela 6 estão os resultados relativos aos motivos de instauração para os processos de TCE em cada colegiado. Como já foi descrito anteriormente, os motivos de instauração são baseados no art. 16, inciso III, alínea "a", "b", "c" ou "d" do regimento interno do TCU (2015). No que se refere a distribuição da variável motivo de instauração, está foi dividida em seis categorias, uma para cada alínea (quatro no total), uma quinta categoria referente a uma combinação de atos infracionais (e.g., alínea "a", "b" e "c" ou "a" e "b"), e a sexta para casos sigilosos. Em todos os colegiados, a categoria de motivos de instauração mais frequente foi a mais de uma ato (combinação de alíneas). 
Tabela 5

Frequência (e porcentagem) de processos de TCE por região do Brasil da unidade federativa onde ocorreu a irregularidade em todos colegiados em todas as amostras

\begin{tabular}{|c|c|c|c|c|c|c|c|c|c|}
\hline \multirow[b]{2}{*}{$\begin{array}{l}\text { Região do } \\
\text { Brasil }\end{array}$} & \multicolumn{3}{|c|}{$1^{\text {a }}$ Câmara } & \multicolumn{3}{|c|}{$2^{\mathrm{a}}$ Câmara } & \multicolumn{3}{|c|}{ Plenário } \\
\hline & $\begin{array}{c}\text { Amostra } \\
1\end{array}$ & $\begin{array}{c}\text { Amostra } \\
2\end{array}$ & $\begin{array}{c}\text { Amostra } \\
\text { total }\end{array}$ & $\begin{array}{c}\text { Amostra } \\
1\end{array}$ & $\begin{array}{c}\text { Amostra } \\
2\end{array}$ & $\begin{array}{c}\text { Amostra } \\
\text { total }\end{array}$ & $\begin{array}{c}\text { Amostra } \\
1\end{array}$ & $\begin{array}{c}\text { Amostra } \\
2\end{array}$ & $\begin{array}{c}\text { Amostra } \\
\text { total }\end{array}$ \\
\hline Centro-Oeste & $\begin{array}{c}19 \\
(12,9)\end{array}$ & $\begin{array}{c}17 \\
(12,7)\end{array}$ & $\begin{array}{c}36 \\
(12,6)\end{array}$ & $\begin{array}{c}15 \\
(10,5)\end{array}$ & $\begin{array}{c}31 \\
(18,3)\end{array}$ & $\begin{array}{c}46 \\
(14,7)\end{array}$ & $\begin{array}{c}14 \\
(18,2)\end{array}$ & $\begin{array}{c}10 \\
(14,7)\end{array}$ & $\begin{array}{c}24 \\
(16,6)\end{array}$ \\
\hline Nordeste & $\begin{array}{c}58 \\
(38,4)\end{array}$ & $\begin{array}{c}56 \\
(41,8)\end{array}$ & $\begin{array}{l}114 \\
(40)\end{array}$ & $\begin{array}{c}61 \\
(42,7)\end{array}$ & $\begin{array}{c}53 \\
(31,4)\end{array}$ & $\begin{array}{c}114 \\
(36,5)\end{array}$ & $\begin{array}{c}23 \\
(29,9)\end{array}$ & $\begin{array}{c}28 \\
(41,2)\end{array}$ & $\begin{array}{c}51 \\
(35,2)\end{array}$ \\
\hline Norte & $\begin{array}{c}19 \\
(12,6)\end{array}$ & $\begin{array}{c}23 \\
(17,2)\end{array}$ & $\begin{array}{c}42 \\
(14,7)\end{array}$ & $\begin{array}{c}34 \\
(23,8)\end{array}$ & $\begin{array}{c}33 \\
(19,5)\end{array}$ & $\begin{array}{c}67 \\
(21,5)\end{array}$ & $\begin{array}{c}10 \\
(13)\end{array}$ & $\begin{array}{c}5 \\
(7,4)\end{array}$ & $\begin{array}{c}15 \\
(10,3)\end{array}$ \\
\hline Sudeste & $\begin{array}{c}35 \\
(23,2)\end{array}$ & $\begin{array}{c}30 \\
(22,4)\end{array}$ & $\begin{array}{c}65 \\
(22,8)\end{array}$ & $\begin{array}{c}26 \\
(18,2)\end{array}$ & $\begin{array}{c}37 \\
(21,9)\end{array}$ & $\begin{array}{c}63 \\
(20,2)\end{array}$ & $\begin{array}{c}23 \\
(29,9)\end{array}$ & $\begin{array}{c}19 \\
(27,9)\end{array}$ & $\begin{array}{c}42 \\
(29)\end{array}$ \\
\hline Sul & $\begin{array}{c}20 \\
(13,2)\end{array}$ & $\begin{array}{c}8 \\
(6)\end{array}$ & $\begin{array}{c}28 \\
(9,8)\end{array}$ & $\begin{array}{c}7 \\
(4,9)\end{array}$ & $\begin{array}{c}15 \\
(8,9)\end{array}$ & $\begin{array}{c}22 \\
(7,1)\end{array}$ & $\begin{array}{c}7 \\
(9,1)\end{array}$ & $\begin{array}{c}6 \\
(8,8)\end{array}$ & $\begin{array}{l}13 \\
(9)\end{array}$ \\
\hline Total & $\begin{array}{c}151 \\
(100)\end{array}$ & $\begin{array}{c}134 \\
(100)\end{array}$ & $\begin{array}{c}285 \\
(100)\end{array}$ & $\begin{array}{c}143 \\
(100)\end{array}$ & $\begin{array}{c}169 \\
(100)\end{array}$ & $\begin{array}{c}312 \\
(100)\end{array}$ & $\begin{array}{c}77 \\
(100)\end{array}$ & $\begin{array}{c}68 \\
(100)\end{array}$ & $\begin{array}{c}145 \\
(100)\end{array}$ \\
\hline
\end{tabular}

Nota. $N=$ Amostra 1: 371; Amostra 2: 371; Amostra total: 742.

A categoria de ato infracional menos frequente nos casos da $1^{\mathrm{a}}$ e $2^{\mathrm{a}}$ Câmara foi a alínea "d" (desfalque ou desvio de dinheiros, bens ou valores públicos), enquanto que para o Plenário foi a alínea "a" (omissão no dever de prestar contas). Também vale a pena ressaltar que nos casos classificados como sigilosos, não foi possível identificar o tipo de ato infracional. Tais casos foram verificados apenas no Plenário. 
Tabela 6

Frequência (e porcentagem) de motivos de instauração de processo de TCE por colegiado em todas as amostras

\begin{tabular}{|c|c|c|c|c|c|c|c|c|c|}
\hline \multirow{2}{*}{$\begin{array}{l}\text { Motivo de } \\
\text { instauração } \\
\text { - Alínea }\end{array}$} & \multicolumn{3}{|c|}{$1^{\mathrm{a}}$ Câmara ${ }^{a}$} & \multicolumn{3}{|c|}{$2^{\mathrm{a}}$ Câmara ${ }^{a}$} & \multicolumn{3}{|c|}{ Plenário $^{a}$} \\
\hline & $\begin{array}{c}\text { Amostra } \\
1\end{array}$ & $\begin{array}{c}\text { Amostra } \\
2\end{array}$ & $\begin{array}{c}\text { Amostra } \\
\text { total }\end{array}$ & $\begin{array}{c}\text { Amostra } \\
1\end{array}$ & $\begin{array}{c}\text { Amostra } \\
2\end{array}$ & $\begin{array}{c}\text { Amostra } \\
\text { total }\end{array}$ & $\begin{array}{c}\text { Amostra } \\
1\end{array}$ & $\begin{array}{c}\text { Amostra } \\
2\end{array}$ & $\begin{array}{c}\text { Amostra } \\
\text { total }\end{array}$ \\
\hline A & $\begin{array}{c}23 \\
(15,2)\end{array}$ & $\begin{array}{c}20 \\
(14,9)\end{array}$ & $\begin{array}{c}43 \\
(15,1)\end{array}$ & $\begin{array}{c}20 \\
(14)\end{array}$ & $\begin{array}{c}21 \\
(12,4)\end{array}$ & $\begin{array}{c}41 \\
(13,1)\end{array}$ & $\begin{array}{c}1 \\
(1,3)\end{array}$ & $\begin{array}{c}1 \\
(1,5)\end{array}$ & $\begin{array}{c}2 \\
(1,4)\end{array}$ \\
\hline B & $\begin{array}{c}26 \\
(17,2)\end{array}$ & $\begin{array}{c}30 \\
(22,4)\end{array}$ & $\begin{array}{c}56 \\
(19,6)\end{array}$ & $\begin{array}{c}19 \\
(13,3)\end{array}$ & $\begin{array}{c}33 \\
(19,5)\end{array}$ & $\begin{array}{c}52 \\
(16,7)\end{array}$ & $\begin{array}{c}13 \\
(16,9)\end{array}$ & $\begin{array}{c}11 \\
(16,2)\end{array}$ & $\begin{array}{c}24 \\
(16,6)\end{array}$ \\
\hline $\mathrm{C}$ & $\begin{array}{c}41 \\
(27,2)\end{array}$ & $\begin{array}{c}32 \\
(23,9)\end{array}$ & $\begin{array}{c}73 \\
(25,6)\end{array}$ & $\begin{array}{c}49 \\
(34,4)\end{array}$ & $\begin{array}{c}50 \\
(29,6)\end{array}$ & $\begin{array}{c}99 \\
(31,7)\end{array}$ & $\begin{array}{c}16 \\
(20,8)\end{array}$ & $\begin{array}{c}12 \\
(17,6)\end{array}$ & $\begin{array}{c}28 \\
(19,3)\end{array}$ \\
\hline $\mathrm{D}$ & $\begin{array}{c}18 \\
(11,9)\end{array}$ & $\begin{array}{c}11 \\
(8,2)\end{array}$ & $\begin{array}{c}29 \\
(10,2)\end{array}$ & $\begin{array}{c}13 \\
(9,1)\end{array}$ & $\begin{array}{c}11 \\
(6,5)\end{array}$ & $\begin{array}{c}24 \\
(7,7)\end{array}$ & $\begin{array}{c}18 \\
(23,4)\end{array}$ & $\begin{array}{c}14 \\
(20,6)\end{array}$ & $\begin{array}{c}32 \\
(22,1)\end{array}$ \\
\hline $\begin{array}{l}\text { Mais de um } \\
\text { ato }\end{array}$ & $\begin{array}{c}43 \\
(28,5)\end{array}$ & $\begin{array}{c}41 \\
(30,6)\end{array}$ & $\begin{array}{c}84 \\
(29,5)\end{array}$ & $\begin{array}{c}42 \\
(29,4)\end{array}$ & $\begin{array}{c}54 \\
(32)\end{array}$ & $\begin{array}{c}96 \\
(30,8)\end{array}$ & $\begin{array}{c}21 \\
(27,3)\end{array}$ & $\begin{array}{c}24 \\
(35,3)\end{array}$ & $\begin{array}{c}45 \\
(30,9)\end{array}$ \\
\hline Sigiloso & $\begin{array}{c}0 \\
(0)\end{array}$ & $\begin{array}{c}0 \\
(0)\end{array}$ & $\begin{array}{c}0 \\
(0)\end{array}$ & $\begin{array}{c}0 \\
(0)\end{array}$ & $\begin{array}{c}0 \\
(0)\end{array}$ & $\begin{array}{c}0 \\
(0)\end{array}$ & $\begin{array}{c}8 \\
(10,4)\end{array}$ & $\begin{array}{c}6 \\
(8,8)\end{array}$ & $\begin{array}{c}14 \\
(9,7)\end{array}$ \\
\hline Total & $\begin{array}{c}151 \\
(100)\end{array}$ & $\begin{array}{c}134 \\
(100)\end{array}$ & $\begin{array}{c}285 \\
(100)\end{array}$ & $\begin{array}{c}143 \\
(100)\end{array}$ & $\begin{array}{c}169 \\
(100)\end{array}$ & $\begin{array}{c}312 \\
(100)\end{array}$ & $\begin{array}{c}77 \\
(100)\end{array}$ & $\begin{array}{c}68 \\
(100)\end{array}$ & $\begin{array}{c}16 \\
(100)\end{array}$ \\
\hline
\end{tabular}

Nota. ${ }^{a} N=$ Amostra 1: 371; Amostra 2: 371; Amostra total: 742

A tabela 7 contém dados referentes ao tempo de duração calculado em anos dos processos de TCE em cada um dos colegiados. É possível verificar que o tempo dos processos que ocorreram no Plenário são em média maiores do que aqueles da $1^{\mathrm{a}}$ e $2^{\mathrm{a}}$ Câmara.

Os dados referente ao número de acórdão emitidos em cada processo de TCE estão descritos na Tabela 8. Tal como indicam os resultados, um processo de TCE pode possuir mais de um acórdão, sendo que esses acórdãos podem ser de decisão, relação, embargos ou recurso. Também se verificou que os casos de TCE que transcorreram no Plenário possuem em média um número maior de acórdãos por processo, do que aqueles das duas Câmaras. 
Tabela 7

Médias, desvio padrão e distribuição das medidas referentes a duração dos processos de TCE em anos em todos os colegiados e amostras

\begin{tabular}{lccccccc}
\hline Colegiado & Amostra $^{a}$ & $\mathrm{~N}$ & Amplitude & Mínimo & Máximo & $M$ & $D P$ \\
\hline \multirow{2}{*}{$1^{\text {a }}$ Câmara } & 1 & 151 & 14,21 & 0,26 & 14,47 & 3,77 & 2,61 \\
& 2 & 134 & 13,40 & 0,64 & 14,04 & 4,01 & 2,89 \\
& Total & 285 & 14,21 & 0,26 & 14,47 & 3,88 & 2,74 \\
& 1 & 143 & 18,07 & 0,48 & 18,55 & 3,54 & 2,81 \\
$2^{\text {a }}$ Câmara & 2 & 169 & 15,67 & 0,50 & 16,17 & 3,49 & 2,63 \\
& Total & 312 & 18,07 & 0,48 & 18,55 & 3,51 & 2,71 \\
Plenário & 1 & 77 & 12,39 & 0,82 & 13,21 & 5,64 & 3,38 \\
& 2 & 68 & 15,80 & 0,61 & 16,41 & 5,84 & 3,36 \\
\hline
\end{tabular}

Nota. ${ }^{a} N$ (processos analisados) $=$ Amostra 1: 371; Amostra 2: 371; Amostra total: 742.

Tabela 8

Médias, desvio padrão e distribuição das medidas referentes ao número de acórdãos emitidos nos processos de TCE em todos os colegiados e amostras

\begin{tabular}{|c|c|c|c|c|c|c|c|}
\hline Colegiado & Amostra $^{a}$ & $\mathrm{~N}$ & Amplitude & Mínimo & Máximo & $M$ & $D P$ \\
\hline \multirow{3}{*}{$1^{\text {a }}$ Câmara } & 1 & 151 & 5 & 1 & 6 & 1,87 & 1,07 \\
\hline & 2 & 134 & 5 & 0 & 5 & 1,79 & 1,13 \\
\hline & Total & 285 & 6 & 0 & 6 & 1,83 & 1,09 \\
\hline \multirow{3}{*}{$2^{\mathrm{a}}$ Câmara } & 1 & 143 & 6 & 1 & 7 & 1,65 & 0,98 \\
\hline & 2 & 169 & 5 & 0 & 5 & 1,69 & 0,96 \\
\hline & Total & 312 & 7 & 0 & 7 & 1,67 & 0,97 \\
\hline \multirow{3}{*}{ Plenário } & 1 & 76 & 6 & 1 & 7 & 2,33 & 1,39 \\
\hline & 2 & 68 & 8 & 1 & 9 & 2,48 & 1,74 \\
\hline & Total & 144 & 8 & 1 & 9 & 2,40 & 1,56 \\
\hline
\end{tabular}

Nota. ${ }^{a} N($ processos analisados $)=$ Amostra 1: 371; Amostra 2: 371; Amostra total: 742 . 
Na Tabela 9 estão apresentados os dados referentes aos processos apensados (processos que são tramitados em conjunto com outros). Os valores médios para o número de processos apensados no Plenário são superiores daqueles encontrados nas duas Câmaras, enquanto que os valores da $1^{\text {a }}$ Câmara são que os da $2^{\text {a }}$ Câmara.

Tabela 9

Médias, desvio padrão e distribuição das medidas referentes ao número de processos apensados aos processos de TCE em todos os colegiados e amostras

\begin{tabular}{|c|c|c|c|c|c|c|c|}
\hline Colegiado & Amostra $^{a}$ & $\mathrm{~N}$ & Amplitude & Mínimo & Máximo & $M$ & $D P$ \\
\hline \multirow{3}{*}{$1^{\mathrm{a}}$ Câmara } & 1 & 151 & 27 & 0 & 27 & 3,75 & 4,68 \\
\hline & 2 & 134 & 28 & 0 & 28 & 3,79 & 4,62 \\
\hline & Total & 285 & 28 & 0 & 28 & 3,77 & 4,64 \\
\hline \multirow{3}{*}{$2^{\mathrm{a}}$ Câmara } & 1 & 143 & 12 & 0 & 12 & 2,85 & 2,09 \\
\hline & 2 & 169 & 33 & 0 & 33 & 3,07 & 3,92 \\
\hline & Total & 312 & 33 & 0 & 33 & 2,97 & 3,21 \\
\hline \multirow{3}{*}{ Plenário } & 1 & 76 & 30 & 0 & 30 & 5,35 & 6,57 \\
\hline & 2 & 68 & 30 & 0 & 30 & 6,62 & 6,22 \\
\hline & Total & 145 & 30 & 0 & 30 & 5,94 & 6,42 \\
\hline
\end{tabular}

Nota. ${ }^{a} N$ (processos analisados $)=$ Amostra 1: 371; Amostra 2: 371; Amostra total: 742.

Tipo de sanção. Nessa seção estão descritos os resultados das análises descritivas relativas a variáveis relacionadas as sanções propostas pelos relatores em processos de TCE. As análises se referem a três tipos de sanção: multa baseada no art. 57 ou 58 e inabilitação.

As análises descritivas para os valores da multa baseada no art. 57 (multa 57) estão descritos na Tabela 10. De modo geral, os resultados indicaram que os valores médios entre amostras para cada um dos colegiados não apresentaram grandes variações. Também foi possível 
verificar que os valores das multas dos processos que transcorreram no Plenário foram em média superiores aos das duas Câmaras.

Tabela 10

Médias, desvio padrão e distribuição das medidas referentes a multa baseada no art. 57 (multa 57) aplicada em processos de TCE em todos os colegiados e amostras

\begin{tabular}{|c|c|c|c|c|c|c|c|}
\hline Colegiado & Amostra $^{a}$ & $\mathrm{~N}$ & Amplitude & Mínimo & Máximo & $M$ & $D P$ \\
\hline \multirow{3}{*}{$1^{a}$ Câmara } & 1 & 118 & 298000 & 2000 & 300000 & 18687,22 & 35473,98 \\
\hline & 2 & 103 & 98500 & 1500 & 100000 & 14231,07 & 16374,07 \\
\hline & Total & 221 & 298500 & 1500 & 300000 & 16610,37 & 28257,94 \\
\hline \multirow{3}{*}{$2^{\mathrm{a}}$ Câmara } & 1 & 119 & 89500 & 500 & 90000 & 11807,14 & 14624,75 \\
\hline & 2 & 126 & 248500 & 1500 & 250000 & 15234,13 & 26678,96 \\
\hline & Total & 245 & 249500 & 500 & 250000 & 13569,59 & 21702,89 \\
\hline \multirow{3}{*}{ Plenário } & 1 & 53 & 248000 & 2000 & 250000 & 38843,39 & 54298,99 \\
\hline & 2 & 40 & 198000 & 2000 & 200000 & 44387,50 & 52524,78 \\
\hline & Total & 93 & 248000 & 2000 & 250000 & 41227,96 & 53325,47 \\
\hline
\end{tabular}

Nota. ${ }^{a} N($ processos analisados $)=$ Amostra 1: 371; Amostra 2: 371; Amostra total: 742.

Os resultados relativos a porcentagem da multa baseada no art. 57 (\% multa 57) estão dispostos na Tabela 11. De acordo com o a Lei Orgânica do TCU (2002), a multa baseada no art. 57 tem o seu valor baseado no valor do dano a erário cometido pelo gestor (montante do débito), podendo chegar até $100 \%$ do valor do débito. Os resultados indicaram que os valores médios foram superiores nos casos que ocorreram no Plenário (cerca de 20\%) do que o valores identificados nas duas Câmaras (16,88 para a $1^{\mathrm{a}}$ Câmara e $14,60 \%$ para a $2^{\mathrm{a}}$ ).

A Tabela 12 contém os resultados descritivos relativos aos valores da multa baseada no art. 58 (multa 58). Assim como foram verificados para outras variáveis, os valores não 
apresentaram grandes variações entre amostras e foram maiores no Plenário do que nos demais colegiados ( $1^{\mathrm{a}}$ e $2^{\mathrm{a}}$ Câmara).

Tabela 11

Médias, desvio padrão e distribuição das medidas

referentes a porcentagem da multa baseada no art. 57 (\% multa 57) aplicada em processos de TCE em todos os colegiados e amostras

\begin{tabular}{lccccccc}
\hline Colegiado & Amostra $^{a}$ & $\mathrm{~N}$ & Amplitude & Mínimo & Máximo & $M$ & $D P$ \\
\hline \multirow{2}{*}{$1^{\text {a }}$ Câmara } & 1 & 117 & 100 & 0 & 100 & 18,29 & 18,54 \\
& 2 & 103 & 63,72 & 0,28 & 64 & 15,41 & 12,22 \\
& Total & 220 & 100 & 0 & 100 & 16,94 & 15,93 \\
& 1 & 119 & 61,60 & 0,31 & 61 & 14,10 & 11,59 \\
$2^{\text {a }}$ Câmara & 2 & 126 & 63,89 & 0,11 & 64 & 15,10 & 12,42 \\
& Total & 245 & 63,89 & 0,11 & 64 & 14,62 & 12,01 \\
& 1 & 49 & 99,37 & 0,63 & 100 & 19,58 & 20,78 \\
Plenário & 2 & 38 & 83 & 1 & 84 & 20 & 18,58 \\
& Total & 87 & 99,37 & 0,63 & 100 & 19,76 & 19,73 \\
\hline
\end{tabular}

Nota. ${ }^{a} N$ (processos analisados $)=$ Amostra 1: 371; Amostra 2: 371; Amostra total: 742.

A Tabela 13 contém os dados relativos a porcentagem da multa prevista pelo art. 58. De acordo com a Lei Orgânica do TCU (2002), o valor dessa multa é estabelecido anualmente pelo TCU, podendo variar de 5\% a 95\% (valor máximo de $\mathrm{R} \$ 54.820,84$ ). Os valores para a variável $\%$ multa 58 foram calculados usando como base o ano em que o processo foi finalizado, e os resultados indicaram que os valores estabelecidos para essa multa no Plenário foram superiores do que nas duas Câmaras. 
Tabela 12

Médias, desvio padrão e distribuição das medidas referentes a multa baseada no art. 58 (multa 58) aplicada em processos de TCE em todos os colegiados e amostras

\begin{tabular}{lccccccc}
\hline Colegiado & $\begin{array}{c}\text { Amostra } \\
a\end{array}$ & $\mathrm{~N}$ & Amplitude & Mínimo & Máximo & $M$ & $D P$ \\
\hline \multirow{2}{*}{$1^{\text {a Câmara }}$} & 1 & 24 & 8350 & 1650 & 10000 & 4172,92 & 2327,11 \\
& 2 & 22 & 18500 & 1500 & 20000 & 5770,09 & 3867,63 \\
& Total & 46 & 18500 & 1500 & 20000 & 4936,78 & 3224,79 \\
$2^{\text {a }}$ Câmara & 1 & 18 & 8000 & 2000 & 10000 & 4611,11 & 2145,83 \\
& 2 & 30 & 9000 & 1000 & 10000 & 4016,67 & 2451,19 \\
& Total & 48 & 9000 & 1000 & 10000 & 4239,58 & 2336,09 \\
Plenário & 1 & 14 & 28000 & 2000 & 30000 & 6571,43 & 7408,04 \\
& 2 & 18 & 28250 & 1750 & 30000 & 6486,11 & 7238,82 \\
\hline
\end{tabular}

Nota. ${ }^{a} N($ processos analisados $)=$ Amostra 1: 371; Amostra 2: 371; Amostra total: 742.

Tabela 13

Médias, desvio padrão e distribuição das medidas referentes a porcentagem da multa baseada no art. 58 (\% multa 58) aplicada em processos de TCE em todos os colegiados e amostras

\begin{tabular}{|c|c|c|c|c|c|c|c|}
\hline Colegiado & Amostra $^{a}$ & $\mathrm{~N}$ & Amplitude & Mínimo & Máximo & $M$ & $D P$ \\
\hline \multirow{3}{*}{$1^{\mathrm{a}}$ Câmara } & 1 & 24 & 21 & 5 & 26 & 10,96 & 5,65 \\
\hline & 2 & 22 & 53 & 4 & 57 & 15,18 & 10,91 \\
\hline & Total & 46 & 53 & 4 & 57 & 12,98 & 8,75 \\
\hline \multirow{3}{*}{ 2a Câmara } & 1 & 17 & 22 & 5 & 27 & 13,059 & 6,79 \\
\hline & 2 & 30 & 27 & 3 & 30 & 10,50 & 6,41 \\
\hline & Total & 47 & 27 & 3 & 30 & 11,425 & 6,60 \\
\hline \multirow[b]{2}{*}{ Plenário } & 1 & 14 & 90 & 5 & 95 & 18,64 & 23,57 \\
\hline & 2 & 18 & 87 & 4 & 91 & 16,94 & 21,25 \\
\hline
\end{tabular}




$\begin{array}{lllllll}\text { Total } & 32 & 91 & 4 & 95 & 17,69 & 21,94\end{array}$

Nota. ${ }^{a} N$ (processos analisados) $=$ Amostra 1: 371; Amostra 2: 371; Amostra total: 742.

A Tabela 14 contém os dados relacionados a sanção de inabilitação (cinco a oito anos inabilitado de ocupar cargo públicos). A frequência dessa sanção foi relativamente baixa na $1^{\mathrm{a}}$ Câmara e $2^{\mathrm{a}}$ Câmara (no máximo 4\% dos casos). No entanto, verificou-se que no Plenário a sanção de inabilitação foi muito mais frequente, pois ocorreu em cerca $26 \%$ dos casos considerando todas as amostras.

Tabela 14

Frequência (e porcentagem) de ocorrência de sanção de inabilitação nos processos de TCE em todos colegiados e amostras

\begin{tabular}{|c|c|c|c|c|c|c|c|c|c|}
\hline \multirow[b]{2}{*}{ Inabilitação } & \multicolumn{3}{|c|}{$1^{\text {a }}$ Câmara } & \multicolumn{3}{|c|}{$2^{\mathrm{a}}$ Câmara } & \multicolumn{3}{|c|}{ Plenário } \\
\hline & $\begin{array}{c}\text { Amostra } \\
1 \\
\end{array}$ & $\begin{array}{c}\text { Amostra } \\
2\end{array}$ & $\begin{array}{c}\text { Amostra } \\
\text { total }\end{array}$ & $\begin{array}{c}\text { Amostra } \\
1 \\
\end{array}$ & $\begin{array}{c}\text { Amostra } \\
2 \\
\end{array}$ & $\begin{array}{c}\text { Amostra } \\
\text { total }\end{array}$ & $\begin{array}{c}\text { Amostra } \\
1 \\
\end{array}$ & $\begin{array}{c}\text { Amostra } \\
2\end{array}$ & $\begin{array}{c}\text { Amostra } \\
\text { total }\end{array}$ \\
\hline \multirow[b]{2}{*}{ Sim } & 6 & 3 & 9 & 1 & 2 & 3 & 18 & 19 & 37 \\
\hline & (4) & (4) & $(3,2)$ & $(0,7)$ & $(1,2)$ & (1) & $(23,4)$ & $(27,9)$ & $(25,5)$ \\
\hline \multirow[b]{2}{*}{ Não } & 145 & 131 & 276 & 142 & 167 & 309 & 59 & 49 & 108 \\
\hline & (96) & $(97,8)$ & $(96,8)$ & $(99,3)$ & $(98,8)$ & (99) & $(76,6)$ & $(72,1)$ & $(74,5)$ \\
\hline \multirow{2}{*}{ Total } & 151 & 134 & 285 & 143 & 169 & 312 & 77 & 68 & 145 \\
\hline & (100) & (100) & (100) & (100) & $(100)$ & (100) & (100) & (100) & (100) \\
\hline
\end{tabular}

Nota. $N=$ Amostra 1: 371; Amostra 2: 371; Amostra total: 742 .

Análises inferenciais. As análises inferenciais aqui descritas foram realizadas com dois objetivos: Primeiro, verificar se existem diferenças estatisticamente significantes entre as variáveis relacionadas as decisões realizadas em processos de TCE (e.g., montante analisado, montante do débito, multa 57, \% multa 57, cargo do gestor, motivo de instauração, etc.) que ocorreram nos três colegiados (i.e., Plenário, $1^{\mathrm{a}}$ Câmara e $2^{\mathrm{a}}$ Câmara). E segundo, verificar o quanto que tais variáveis servem como preditores para variações entre tais decisões. Portanto, na 
investigação da ocorrência de tais regularidades, as análises foram conduzidas em duas etapas: análises de variância unidirecional (ANOVA) e regressões lineares múltiplas.

Análises de variância. Portanto, primeiramente, para verificar se existem diferenças significativas entre as diversas variáveis relacionadas ao processo e os três colegiados, diversas análises de variância (ANOVA unidirecional) foram calculadas comparando todas as medidas aferidas relacionadas ao processo em comparação com cada um dos colegiados em todas as amostras. Essas medidas representam tanto decisões dos relatores (i.e., sanções), quanto características do processo (e.g., duração do processo, acórdãos, montante do débito). Também é importante salientar que a identificação de diferenças significativas a partir das análises de variância também servirão de critério para construir um modelo de regressão linear múltipla que será apresentada posteriormente.

Desse modo, a Tabela 15 contém os parâmetros aferidos a partir do teste ANOVA para as variáveis relacionadas ao processo. No entanto, com intuito de descrever dados consistentes e interpretáveis, só foram descritos os dados referentes que foram significantes $(p>0,05)$ nas três amostras (e.g., amostra 1 e amostra total). As exceções a esse critério foram a variáveis montante do débito ( $p>0,05$ em duas das três amostras), multa 58 e \% multa 58 ( $p>0,10$, apenas na amostra total) na amostra total. Especificamente no caso da multa 58 e \% multa 58 esse critério foi adotado em função dessas variáveis estarem relacionadas diretamente a decisões dos relatores do processo, pois representam um tipo específico de sanção (variáveis dependentes).

Além disso, tendo em vista que para grande parte das análises descritas na Tabela 15 apresentaram resultados significantes, testes post hoc (Tukey HSD) também foram conduzidos entre todos os possíveis pares de colegiado (e.g., Plenário X $1^{\mathrm{a}}$ Câmara X $2^{\mathrm{a}}$ Câmara) com intuito de verificar especificamente em quais dos colegiados existem diferenças significantes para os 
valores das variáveis relacionadas aos processos de TCE. Os testes post hoc também destacaram que a $1^{\text {a }}$ Câmara e a $2^{\text {a }}$ Câmara não apresentam diferenças estatisticamente significantes entre si, enquanto que pra maior parte das variáveis foram identificadas diferenças entre as médias das variáveis relacionadas aos processos de TCE do Plenário quando comparada as duas Câmaras. Em outras palavras, tanto os testes post hoc quanto as análises descritivas das médias indicaram que os valores aferidos para características do processo são sempre maiores no Plenário do que nas duas Câmaras. Por fim, apesar de grande parte das análises indicarem que os valores relacionados aos processos transcorrido na $1^{\mathrm{a}}$ Câmara serem maiores do que aqueles da $2^{\mathrm{a}}$ Câmara, tais diferenças não apresentaram significância estatística.

Com intuito de aumentar a confiabilidade dos dados que verificaram diferenças entre os grupos, além das análises de variância (ANOVA), também foram realizadas comparações entre as médias a partir de análises não-paramétricas. Como Field (2009) destaca, o equivalente nãoparamétrico para a ANOVA é a análise Kruskal-Wallis, desse modo, tais análises foram realizadas e os resultados foram praticamente idênticos a aqueles aferidos pela ANOVA. A única exceção se referiu à variável inabilitação, que por se tratar de uma variável categórica (i.e., sim ou não), essa não pôde ser analisada a partir da Kurskal-Wallis. 
Tabela 15

Valores aferidos para a análise de variância unidirecional (ANOVA, teste post-hoc (Tukey's HSD) e comparação entre médias para as variáveis referentes aos processos de TCE em todos os colegiados e amostras

\begin{tabular}{|c|c|c|c|c|c|}
\hline Variável & Amostra $^{a}$ & $g l$ & $F$ & $p$ & $\begin{array}{c}\text { Comparação entre médias }{ }^{b} \\
\text { Tukey HSD }{ }^{c}\end{array}$ \\
\hline \multirow[t]{3}{*}{ Acórdãos total } & 1 & $(2,368)$ & 9,24 & 0,00 & $3 * * *>1,2 / 1>2$ \\
\hline & 2 & $(2,368)$ & 11,17 & 0,00 & $3 * * *>1,2 / 1>2$ \\
\hline & Total & $(2,739)$ & 20,12 & 0,00 & $3 * * *>1,2 / 1>2$ \\
\hline \multirow[t]{3}{*}{ Duração do processo } & 1 & $(2,368)$ & 14,88 & 0,00 & $3 * * *>1,2 / 1>2$ \\
\hline & 2 & $(2,368)$ & 16,42 & 0,00 & $3 * * *>1,2 / 1>2$ \\
\hline & Total & $(2,739)$ & 31,09 & 0,00 & $3 * * *>1,2 / 1>2$ \\
\hline \multirow[t]{3}{*}{ Inabilitação } & 1 & $(2,368)$ & 25,70 & 0,00 & $3 * * *>1,2 / 1>2$ \\
\hline & 2 & $(2,368)$ & 38,06 & 0,00 & $3 * * *>1,2 / 1>2$ \\
\hline & Total & $(2,739)$ & 61,37 & 0,00 & $3 * * *>1,2 / 1>2$ \\
\hline \multirow[t]{3}{*}{ Montante do débito } & 1 & $(2,302)$ & 6,53 & 0,01 & $3 * * *>1,2 / 1>2$ \\
\hline & 2 & $(2,345)$ & 2,43 & 0,09 & $3>1,2 / 2>1$ \\
\hline & Total & $(2,650)$ & 6,27 & 0,00 & $3 * * *>1,2 / 2>1$ \\
\hline \multirow[t]{3}{*}{ Multa 57} & 1 & $(2,290)$ & 5,22 & 0,01 & $3^{* *}>1 / 3^{* * *}>2 / 1>2$ \\
\hline & 2 & $(2,268)$ & 16,85 & 0,00 & $3 * * *>1,2 / 2>1$ \\
\hline & Total & $(2,561)$ & 10,29 & 0,00 & $3 * * *>1,2 / 1>2$ \\
\hline \multirow[t]{3}{*}{$\%$ multa 57} & 1 & $(2,290)$ & 2,77 & 0,06 & $3>1,2 / 1>2$ \\
\hline & 2 & $(2,264)$ & 2,07 & 0,13 & $3>1,2 / 1>2$ \\
\hline & Total & $(2,549)$ & 4,03 & 0,02 & $3^{* *}>1 / 1>2$ \\
\hline \multirow[t]{3}{*}{ Multa 58} & 1 & $(2,52)$ & 1,60 & 0,21 & $3>1,2 / 2>1$ \\
\hline & 2 & $(2,67)$ & 1,92 & 0,15 & $3>1,2 / 1>2$ \\
\hline & Total & $(2,122)$ & 2,82 & 0,06 & $3^{*}>2 / 3>1 / 1>2$ \\
\hline \multirow[t]{3}{*}{$\%$ multa 58} & 1 & $(2,52)$ & 1,58 & 0,22 & $3>1,2 / 2>1$ \\
\hline & 2 & $(2,67)$ & 1,60 & 0,15 & $3>1,2 / 1>2$ \\
\hline & Total & $(2,122)$ & 2,32 & 0,10 & $3^{*}>2 / 3>1 / 1>2$ \\
\hline \multirow[t]{3}{*}{ Processos apensados } & 1 & $(2,368)$ & 8,05 & 0,00 & $3^{* *}>1 / 3^{* * *}>2 / 1>2$ \\
\hline & 2 & $(2,368)$ & 14,17 & 0,00 & $3 * * *>1,2 / 1>2$ \\
\hline & Total & $(2,739)$ & 20,34 & 0,00 & $3 * * *>1,2 / 1>2$ \\
\hline
\end{tabular}

Nota. ${ }^{a} N$ (processos analisados) = Amostra 1: 371; Amostra 2: 371; Amostra total: 742.

${ }^{b}$ Identificação dos grupos para análise dos valores das médias $1=1{ }^{\text {a }}$ Câmara, $1=2^{\mathrm{a}}$ Câmara, $3=$ Plenário.

${ }^{c}$ Diferenças significativas entre grupos verificadas via Tukey HSD: $* * * p<0,01 ; * * p<0,05 ; * p<0,10$. 
Regressões múltiplas. Para a inclusão de variáveis preditoras nas análises de regressão, alguns critérios foram adotados como o intuito de conseguir resultados consistentes e passíveis de interpretação. Primeiramente as variáveis foram divididas em dependentes e independentes. As variáveis multa 57, \% multa 57, multa 58, \% multa 58 e inabilitação descrevem tipos de sanção propostas pelo relator em processos de TCE, portanto, essas foram consideradas variáveis dependentes. Apesar de inabilitação também ser um tipo se sanção, esta não foi incluída como VD por se tratar de uma variável dicotômica. Já no que se refere as variáveis independentes, foram incluídas aquelas que se referem a características do processo tais como, montante analisado, duração do processo, processos apensados, cargo do gestor, e motivo de instauração.

Em segundo lugar, a partir da categorização anterior, foram consideradas para inclusão nos modelos de regressão as variáveis que apresentaram diferenças significantes entre grupos (i.e., colegiados) nas análises de variância conduzidas anteriormente (ver Tabela 15). Além disso, também foi verificada a existência de relações lineares entre as variáveis independentes a partir de uma matriz de correlações (Pearson e Spearman). Isso foi realizado com o intuito de evitar possíveis efeitos de multicolinearidade, já que isso poderia prejudicar o ajuste do modelo (cf. Field, 2009). Por fim, também foram incluídas como preditores as variáveis cargo do gestor e motivo de instauração. De acordo com Epstein et al. (2013) e como está proposto no modelo descrito no Estudo 1 (ver Figura 2), variáveis desse tipo também podem influenciar a decisão dos relatores em função de agregar uma carga social e institucional (status) ao processo em função da gravidade do ato infracional e da importância cargo do gestor que o cometeu.

Apesar da variável independente montante analisado não ter atendido os critérios de inclusão descritos anteriormente, essa também foi inserida no modelo de regressão. Essa foi incluída nas análises pois pode representar um indicativo de interação com consequências 
utilitárias de acordo com o modelo econômico-comportamental operante proposto no Estudo 1 (ver Figura 2). Além disso, tal procedimento se justificou pelas as variáveis dependentes multa 57 e \% multa 57 terem apresentado correlações significantes com montante analisado. Desse modo, para a multa 57 foram verificadas correlações de Pearson significantes na amostra $1(r=$ $0,31, p<0,01)$ e amostra total $(r=0,11, p<0,05)$ e correlações de Spearman significantes $(p<$ 0,01) nas três amostras. Já as correlações significantes $(p<0,01)$ com a variável \% multa 57 foram: $\left(r_{s}=\right.$ amostra 1: 0,32; amostra 2: 0,37; amostra total: 0,35). Apesar das correlações de Pearson não terem apresentado resultados significantes, todos os coeficientes também foram negativos, indicando que existe uma tendência de processos com valores maiores para montante analisado terem as multas baseadas no art. 57 da lei orgânica do TCU (2002) proporcionalmente menores.

Com intuito de se produzir modelos de regressão com resultados confiáveis, também foram testadas as hipóteses de linearidade, homocedasticidade e normalidade dos modelos a partir da análise dos resíduos obtidos pelas regressões (resíduos padronizados vs. resíduos previstos padronizados) (cf. Field, 2009). Desse modo, a partir de uma análise dos diagramas dos resíduos previstos e dos histogramas e diagramas de probabilidades normais dos resíduos obtidos pelas regressões, foi identificado que algumas das premissas essenciais ao uso da regressão múltipla estavam sendo violadas. Portanto, com intuito de resolver esse problema e obter dados confiáveis, se optou realizar uma transformação logarítmica em base natural (Log natural) para todos os valores das variáveis dependentes empregadas no estudo (e.g., multa 57 e \% multa 57). De acordo com Field (2009), tal procedimento ajuda a corrigir a distribuição assimétrica de uma variável na medida em que a normaliza seus valores. 
Vale a pena salientar que apesar dos valores do $R^{2}$ obtidos pelas as regressões empregando valores em Log natural terem apresentado diferenças (geralmente um pouco menores), os coeficientes obtidos foram semelhantes no sentido de quais foram significantes para cada uma das VIs e de sua direção em relação à VD (i.e., positiva ou negativa). Tal procedimento de transformação tornou os dados mais adequados e ajustados dentro de critérios de normalidade e das demais premissas do modelo de regressão, de modo que não foram violadas nenhuma das premissas essenciais a esse tipo de análise. Portanto, todas as regressões relatadas no presente trabalhos empregaram os valores da variável dependente transformados em Log natural.

Baseando-se no critérios descritos acima, três tipos de regressão múltipla foram conduzidas com intuito de verificar preditores relacionados a quatro variáveis dependentes que descrevem sanções estabelecidas pelos relatores em processos de TCE (multa 57, \% multa 57, multa 58, \% multa 58). Os três tipos de regressão múltipla foram realizadas agrupando os seguintes tipos de variáveis: (1) as características do processo, compostas apenas por variáveis contínuas (e.g., montante do débito, duração do processo) versus as quatro sanções (e.g., multa 57); (2) o tipo de cargo ocupado pelo gestor que cometeu a infração (e.g., prefeito ou secretário) versus as sanções; (3) os tipos de infração (motivo de instauração) versus as sanções. A Figura 3 apresenta um esquema demonstrando como as variáveis foram agrupadas para cada um dos três tipos de regressões múltiplas.

Também é necessário enfatizar que em todas as regressões aqui descritas os colegiados foram incluídos como variáveis independentes (preditores), justamente com intuito de verificar se as variações nas sanções estabelecidas em processos de TCE também podem ser atribuídas aos diferentes colegiados. Tendo em vista que o colegiado no qual transcorreu o processo de TCE representa uma variável categórica, o Plenário foi empregado como referência para as regressões 
múltiplas empregando o colegiado. Esse critério se justifica pois as análises de variância (ver Tabela 15) indicaram diferenças significantes e consistentes entre as variáveis apenas para o Plenário quando contrastado com a $1^{\mathrm{a}}$ e $2^{\mathrm{a}}$ Câmara.

\section{B - Variáveis Independentes}

1 - Características do processo

\section{A- Nível de Análise}

\section{Comparações entre Colegiados}

- Duração do processo

- Montante analisado

- Montante do débito

- Processos apensados

2 - Motivo de Instauração

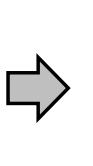

- Plenário vs. $1^{\text {a }}$ Câmara

- Plenário vs. $2^{\mathrm{a}}$ Câmara
- Alínea "d" vs. "a"

- Alínea "d" vs. "b"

- Alínea "d" vs. "c"

- Alínea "d" vs.

"mais de um ato"

\section{3 - Cargo do Gestor}

- Prefeito ou Secretário vs. Presidente ou Diretor

- Prefeito ou Secretário vs. Outros cargos

\section{C- Variáveis Dependentes} Medidas para Sanções

- Multa 57

-\% Multa 57

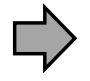

- Multa 58

- \% Multa 58

Figura 3. Esquema representativo dos três tipos de regressões múltiplas conduzidas para o nível de análise de colegiado. Em todas as regressões foram empregados as variáveis A e um dos grupos de variáveis B como preditores (1,2 ou 3) para cada uma das quatros variáveis dependentes $(\mathrm{C})$.

Regressões para a variável multa 57. A Tabela 16 contém os resultados das regressões múltiplas para a variável multa 57 com o primeiro grupo de variáveis independentes (características do processo) para as três amostras. As análises regressões múltiplas indicaram os seguintes resultados para o modelo: $1^{\text {a }}$ amostra, $R^{2}=0,19, F(7,276)=9,49=p<0,01 ; 2^{\text {a }}$ 
amostra, $R^{2}=0,20, F(7,230)=8,13=p<0,01 ;$ amostra completa, $R^{2}=0,17, F(7,514)=15,15$ $=p<0,01$. No que se refere ao efeito específico das variáveis preditoras, apenas os resultados das variáveis que obtiveram coeficientes significantes em pelo menos duas das três amostras foram descritos na Tabela 16. Tal critério foi adotado com o intuito de enfatizar apenas os efeitos consistentes e interpretáveis nas relações entre as variáveis. A partir dos resultados obtidos, é possível interpretar que os processos que tiveram os maiores valores relacionados ao montante do débito e que tenham transcorrido no Plenário tendem a apresentar as maiores multas (multa 57).

Tabela 16

Parâmetros aferidos por regressão múltipla com os preditores relacionados as características do processo para a variável multa 57 em todas as amostras para o nível de análise de colegiado

\begin{tabular}{lcccc}
\hline Variável & Amostra $^{a}$ & $\mathrm{~B}$ & Erro Padrão (B) & $\beta^{b}$ \\
\hline \multirow{3}{*}{ Montante do débito } & 1 & 0 & 0 & $0,393^{* * * *}$ \\
& 2 & 0 & 0 & $0,276^{* * *}$ \\
& Total & 0 & 0 & $0,267^{* * *}$ \\
$1^{\text {a }}$ Câmara vs. Plenário & 1 & $-0,547$ & 0,175 & $-0,250^{* * *}$ \\
& 2 & $-0,964$ & 0,204 & $-0,423^{* * *}$ \\
& Total & $-0,754$ & 0,133 & $-0,339^{* * *}$ \\
$2^{\text {a }}$ Câmara $v s$. Plenário & 1 & $-0,786$ & 0,178 & $-0,360^{* * *}$ \\
& 2 & $-0,992$ & 0,203 & $-0,446^{* * *}$ \\
\hline
\end{tabular}

Nota. ${ }^{a} N$ (processos analisados) $=$ Amostra 1: 371; Amostra 2: 371; Amostra total: 742.

$b * * * p<0,01 ; * * p<0,05 ; * p<0,10$.

No que se refere as regressões para a variável multa 57 empregando os outros dois grupos de variáveis, motivo de instauração e cargo do gestor, a única variável dependente continua inserida nos modelos juntamente com as variáveis dicotômicas foi montante do débito. Esse critério foi adotado pois essa foi a única variável que apresentou coeficientes significantes $(p<$ 
0,00) nas três amostras analisadas anteriormente, indicando que essas variáveis apresentam uma relação linear.

Para analisar o efeito da variável motivo de instauração sobre os valores da multa 57 nos diferentes colegiados, foram conduzidas diversas a regressões com intuito de explorar todos os pares de categorias da variável motivo de instauração. Os resultados indicaram coeficientes significantes consistentes nas as três amostras apenas para as comparações realizadas entre as categorias de atos de infração (alíneas "a", "b", "c" ou "mais de um ato") contrastados com a alínea “d”, e, portanto, só foram apresentados os resultados desse tipo de modelo de regressão. Portanto, os resultados foram os seguintes: $1^{\mathrm{a}}$ amostra, $R^{2}=0,28, F(7,279)=15,86=p<0,01$; $2^{\text {a }}$ amostra, $R^{2}=0,21, F(7,260)=9,79=p<0,01$; amostra completa, $R^{2}=0,22, F(7,547)=$ $21,81=p<0,01$.

A Tabela 17 contém todos os dados para o presente modelo. Dos 21 coeficientes obtidos pela regressão, apenas três deles não foram significantes, e mesmo nesses casos, as tendências foram consistentes (sinais do beta na mesma direção em todas as amostras). Portanto, esses dados indicam uma tendência consistente de relação entre as variáveis inseridas no modelo.

Também é possível verificar na Tabela 17 que todos os coeficientes relacionados aos motivos de instauração e do tipo de colegiado do processos foram negativos. Isso indica que os valores da multa 57 baseadas na alínea "d" foram superiores aos outros motivos de instauração, sobretudo nos processos que ocorreram no Plenário.

Por fim, também está demonstrado na Tabela 17 que assim como no modelo de regressão anterior (ver tabela 16), a variável montante do débito demonstrou ser um preditor consistente para o valor da multa baseada no art. 57, já que esse demonstrou coeficientes significantes nas três amostras. Todos os valores dos coeficientes obtidos para essa variável foram positivos, o que 
indica que maiores valores de débito estão relacionados a maiores valores da multa, sobretudo em processos tramitados no Plenário em que o motivo de instauração envolveu desfalque (i.e., alínea "d").

Tabela 17

Parâmetros aferidos por regressão múltipla com os preditores relacionados a motivo de instauração para a variável multa 57 em todas as amostras para o nível de análise de colegiado

\begin{tabular}{|c|c|c|c|c|}
\hline Variável & Amostra $^{a}$ & $\mathrm{~B}$ & Erro Padrão (B) & $\beta^{b}$ \\
\hline \multirow{3}{*}{ Montante do débito } & 1 & 0 & 0 & $0,342 * * *$ \\
\hline & 2 & 0 & 0 & $0,251 * * *$ \\
\hline & Total & 0 & 0 & $0,251 * * *$ \\
\hline \multirow{3}{*}{$1^{\text {a }}$ Câmara vs. Plenário } & 1 & $-0,251$ & 0,165 & $-0,114$ \\
\hline & 2 & $-0,540$ & 0,125 & $-0,246 * * *$ \\
\hline & Total & $-0,540$ & 0,125 & $-0,246 * * *$ \\
\hline \multirow{3}{*}{ 2a Câmara vs. Plenário } & 1 & $-0,842$ & 0,187 & $-0,393 * * *$ \\
\hline & 2 & $-0,707$ & 0,124 & $-0,327 * * *$ \\
\hline & Total & $-0,707$ & 0,124 & $-0,327 * * *$ \\
\hline \multirow{3}{*}{ Alínea "a" vs. "d" } & 1 & $-1,127$ & 0,210 & $-0,358 * * *$ \\
\hline & 2 & $-0,791$ & 0,160 & $-0,255^{* * *}$ \\
\hline & Total & $-0,791$ & 0,160 & $-0,255 * * *$ \\
\hline \multirow{3}{*}{ Alínea "b" vs. "d" } & 1 & $-1,140$ & 0,260 & $-0,256 * * *$ \\
\hline & 2 & $-0,750$ & 0,294 & $-0,171^{* *}$ \\
\hline & Total & $-0,961$ & 0,197 & $-0,217 * * *$ \\
\hline \multirow{3}{*}{ Alínea "c" vs. "d" } & 1 & $-0,719$ & 0,173 & $-0,313 * * *$ \\
\hline & 2 & $-0,225$ & 0,212 & $-0,097$ \\
\hline & Total & $-0,471$ & 0,135 & $-0,204 * * *$ \\
\hline \multirow{3}{*}{ "Mais de um ato" vs. Alínea "d" } & 1 & $-0,587$ & 0,171 & $-0,253 * * *$ \\
\hline & 2 & $-0,078$ & 0,203 & $-0,035$ \\
\hline & Total & $-0,336$ & 0,132 & $-0,149 * *$ \\
\hline
\end{tabular}

Nota. ${ }^{a} N$ (processos analisados) $=$ Amostra 1: 371; Amostra 2: 371; Amostra total: 742.

$b * * * p<0,01 ; * * p<0,05 ; * p<0,10$.

No que se refere as regressões que analisaram as categorias da variável cargo do gestor (prefeito, presidente ou diretor e outros cargos), os resultados estão apresentados na Tabela 18. 
Só foram verificadas coeficientes consistentes (i.e., significantes e na mesma direção em no mínimo duas amostras) nas análises comparando o cargo de prefeito em relação a outros cargos. Portanto, apenas os modelos de regressão relacionados a essas comparações foram descritos e apresentaram os seguintes resultados: $1^{\mathrm{a}}$ amostra, $R^{2}=0,23, F(5,249)=14,99=p<0,01 ; 2^{\mathrm{a}}$ amostra, $R^{2}=0,22, F(5,222)=12,441=p<0,01$; amostra completa, $R^{2}=0,20, F(5,477)=$ $23,92=p<0,01$.

Como é possível verificar na Tabela 18, os coeficientes relacionados as variáveis colegiado e montante do débito apresentaram tendências semelhantes aos modelos de regressão anteriores (ver Tabelas 17 e 16). Já no que se refere as comparações de casos envolvendo o cargo de prefeito em relação a outros cargos (e.g., tesoureiro, bolsista, funcionário público) aos coeficientes obtidos foram positivos e significantes em duas amostras $(p<0,01)$. Tais resultados indicam que os casos envolvendo outros cargos apresentaram valores de multa superiores em relação aos casos nos quais prefeitos foram os responsáveis pela irregularidade.

Regressões para a variável \% multa 57. A Tabela 19 contém os resultados das regressões múltiplas para a variável \% multa 57 com o primeiro grupo de variáveis independentes (características do processo, ver Figura 3). As análises regressões múltiplas indicaram os seguintes resultados para o presente modelo: $1^{\mathrm{a}}$ amostra, $R^{2}=0,18, F(7,276)=8,62=p<0,01$; $2^{\text {a }}$ amostra, $R^{2}=0,23, F(7,230)=9,68=p<0,01$; amostra completa, $R^{2}=0,16, F(7,514)=$ $14,28=p<0,01$

No que se refere aos coeficientes relacionados aos preditores, só estão descritos na Tabela 19 aqueles que apresentaram valores significantes em pelo menos duas das três amostras. Os resultados indicaram uma relação significante e negativa nas três amostras entre \% multa 57 e 
montante do débito. Isso indica que quanto maior forem os valores do montante do débito proporcionalmente mais baixa tende a ser o valor da multa baseada no art. 57 .

Tabela 18

Parâmetros aferidos por regressão múltipla com os preditores relacionados a cargo do gestor para a variável multa 57 em todas as amostras para o nível de análise de colegiado

\begin{tabular}{lcccc}
\hline Variável & Amostra $^{a}$ & $\mathrm{~B}$ & Erro Padrão (B) & $\beta^{b}$ \\
\hline \multirow{2}{*}{ Montante do débito } & 1 & 0 & 0 & $0,312^{* * *}$ \\
& 2 & 0 & 0 & $0,229 * * *$ \\
& Total & 0 & 0 & $0,242^{* * *}$ \\
$1^{\text {a }}$ Câmara vs. Plenário & 1 & $-0,418$ & 0,191 & $-0,185^{* * *}$ \\
& 2 & $-0,996$ & 0,196 & $-0,456 * * *$ \\
& Total & $-0,753$ & 0,136 & $-0,339 * * *$ \\
$2^{\text {a }}$ Câmara $v s$. Plenário & 1 & $-0,677$ & 0,193 & $-0,301 * * *$ \\
& 2 & $-1,093$ & 0,189 & $-0,513 * * *$ \\
Outros cargos $v s$. Prefeito & Total & $-0,954$ & 0,133 & $-0,435^{* * *}$ \\
& 1 & 0,561 & 0,165 & $0,199 * * *$ \\
& 2 & 0,240 & 0,166 & 0,090 \\
\hline
\end{tabular}

Nota.${ }^{a} N$ (processos analisados) $=$ Amostra 1: 371; Amostra 2: 371; Amostra total: 742.

$b * * * p<0,01 ; * * p<0,05 ; * p<0,10$

Também é possível verificar na Tabela19 que cinco dos seis coeficientes resultantes das comparações entre as duas Câmaras e o Plenário foram negativos e significantes. Isso sugere que os casos tramitados no Plenário tendem a apresentar uma multa maior em termos percentuais do que nas duas Câmaras. Por fim, também foram verificados coeficientes negativos e significantes em dois dos três casos entre \% multa 57 e acórdãos total. Ou seja, aqueles processos com um menor número de acórdãos apresentaram uma tendência de multas proporcionalmente maiores em relação aos processos que produziram mais acórdãos. 
Tabela 19

Parâmetros aferidos por regressão múltipla com os preditores relacionados a características do processo para a variável \% multa 57 em todas as amostras para o nível de análise de colegiado

\begin{tabular}{lcccc}
\hline Variável & Amostra $^{a}$ & $\mathrm{~B}$ & Erro Padrão (B) & $\beta^{b}$ \\
\hline \multirow{3}{*}{ Montante do débito } & 1 & 0 & 0 & $-0,523^{* * *}$ \\
& 2 & 0 & 0 & $-0,391^{* * *}$ \\
& Total & 0 & 0 & $-0,355^{* * *}$ \\
$1^{\text {a }}$ Câmara $v s$. Plenário & 1 & $-0,138$ & 0,168 & $-0,066$ \\
& 2 & $-0,330$ & 0,170 & $-0,171^{*}$ \\
& Total & $-0,221$ & 0,121 & $-0,110^{*}$ \\
$2^{\text {a }}$ Câmara $v s$. Plenário & 1 & $-0,353$ & 0,172 & $-0,170^{* *}$ \\
& 2 & $-0,442$ & 0,168 & $-0,235^{* * *}$ \\
& Total & $-0,371$ & 0,122 & $-0,187^{* * *}$ \\
Acórdãos total & 1 & $-0,147$ & 0,065 & $-0,146^{* *}$ \\
& 2 & $-0,084$ & 0,058 & $-0,102$ \\
& Total & $-0,135$ & 0,044 & $-0,147^{* * *}$ \\
\hline
\end{tabular}

Nota. ${ }^{a} N$ (processos analisados) $=$ Amostra 1: 371; Amostra 2: 371; Amostra total: 742.

$b * * * p<0,01 ; * * p<0,05 ; * p<0,10$.

Os resultados para os modelos de regressão que empregaram o grupo de variáveis independentes relacionadas ao motivo de instauração como preditores para a variável dependente \% multa 57 empregaram os mesmos critérios descritos anteriormente para a variável multa 57. Os resultados para os presentes modelos de regressão foram os seguintes: $1^{\mathrm{a}}$ amostra, $R^{2}=0,21, F(7,279)=10,60=p<0,01 ; 2^{\mathrm{a}} \operatorname{amostra}, R^{2}=0,21, F(7,260)=10,13=p<0,01$; amostra completa, $R^{2}=0,18, F(7,547)=17,61=p<0,01$.

A Tabela 20 apresenta os coeficientes obtidos para os preditores do presente modelo de regressão para a variável dependente \% multa 57. É possível verificar que ocorreram coeficientes significantes em pelo menos duas das três amostras para as quatro categorias da variável motivo de instauração. Mais especificamente, dos 12 coeficientes obtidos apenas três deles não foram significantes $(p<0,10)$, e com exceção de apenas um dos casos não significantes, todos os 
coeficientes foram negativos. Desse modo, os parâmetros relacionados as comparações das categorias da variável motivo de instauração indicam de modo consistente uma relação negativa com o motivo de instauração descrito pela alínea "d”, sugerindo que esse tipo de infração está relacionada aos maiores valores para a variável \% multa 57.

Tabela 20

Parâmetros aferidos por regressão múltipla com os preditores relacionados a motivo de instauração para a variável \% multa 57 em todas as amostras para o nível de análise de colegiado

\begin{tabular}{|c|c|c|c|c|}
\hline Variável & Amostra $^{a}$ & B & Erro Padrão (B) & $\beta^{b}$ \\
\hline \multirow{3}{*}{ Montante do débito } & 1 & 0 & 0 & $-0,385 * * *$ \\
\hline & 2 & 0 & 0 & $-0,453 * * *$ \\
\hline & Total & 0 & 0 & $-0,404 * * *$ \\
\hline \multirow{3}{*}{ 1ª Câmara vs. Plenário } & 1 & 0,022 & 0,166 & 0,010 \\
\hline & 2 & $-0,379$ & 0,171 & $-0,189 * *$ \\
\hline & Total & $-0,112$ & 0,119 & $-0,055$ \\
\hline \multirow{3}{*}{$2^{\mathrm{a}}$ Câmara vs. Plenário } & 1 & $-0,168$ & 0,167 & $-0,080$ \\
\hline & 2 & $-0,459$ & 0,169 & $-0,236 * * *$ \\
\hline & Total & $-0,241$ & 0,118 & $-0,119 * *$ \\
\hline \multirow{3}{*}{ Alínea "a" vs. "d" } & 1 & $-0,704$ & 0,210 & $-0,235 * * *$ \\
\hline & 2 & $-0,017$ & 0,220 & $-0,006$ \\
\hline & Total & $-0,443$ & 0,152 & $-0,153 * * *$ \\
\hline \multirow{3}{*}{ Alínea "b" vs. "d" } & 1 & $-1,032$ & 0,260 & $-0,243 * * *$ \\
\hline & 2 & $-0,438$ & 0,266 & $-0,110$ \\
\hline & Total & $-0,785$ & 0,187 & $-0,191 * * *$ \\
\hline \multirow{3}{*}{ Alínea "c" vs. "d" } & 1 & $-0,389$ & 0,173 & $-0,178 * *$ \\
\hline & 2 & 0,063 & 0,192 & 0,030 \\
\hline & Total & $-0,239$ & 0,129 & $-0,111 *$ \\
\hline \multirow{3}{*}{ "Mais de um ato" vs. Alínea "d" } & 1 & $-0,553$ & 0,172 & $-0,251 * * *$ \\
\hline & 2 & $-0,062$ & 0,184 & $-0,031$ \\
\hline & Total & $-0,365$ & 0,126 & $-0,173 * * *$ \\
\hline
\end{tabular}

Nota. ${ }^{a} N$ (processos analisados $)=$ Amostra 1:371; Amostra 2: 371; Amostra total: 742. $b * * * p<0,01 ; * * p<0,05 ; * p<0,10$. 
No que se refere às comparações das duas Câmaras com o Plenário (i.e., variável colegiado), ainda de acordo com a Tabela 20, os resultados salientam que a valor percentual da multa baseada no art. 57 tende a ser maior no Plenário do que nas duas Câmaras. Isso pôde ser verificado pois todos dos seis coeficientes obtidos foram negativos para as comparações das Câmaras com o Plenários. Além disso, três deles foram significantes $(p<0,05)$, um para as comparações da $1^{\mathrm{a}}$ Câmara com o Plenário (amostra dois) e dois para a $2^{\mathrm{a}}$ Câmara (amostra 2 e total), enfatizando a consistência dessa regularidade.

As regressões que empregaram o cargo do gestor como preditor para \% multa 57 também apresentaram modelos significantes $(\mathrm{p}<0,01)$. No entanto, não foram verificados coeficientes significantes para as categorias relacionadas ao cargo do gestor (i.e., prefeito) em pelo menos duas amostras das três amostras em conjunto com as variáveis para colegiado. Como os resultados obtidos não foram suficientemente consistentes para demonstrar uma tendência de relação interpretável entre a porcentagem da multa baseada no art. 57 em função de cargo ocupado pelo gestor ou responsável por recursos públicos que cometeu a infração, os dados não foram apresentados.

Regressões para as variáveis multa 58 e para \% multa 58. Como é possível verificar na Tabela 15, as análises variância (ANOVA) e comparações entre as médias via Kruskall-Wallis não revelaram resultados consistentes para as variáveis dependentes multa 58 e \% multa 58. Ainda assim, por se tratar de um aspecto relevante relacionado aos processos de TCE, regressões múltiplas também foram conduzidas atendendo os critérios descritos acima. Os resultados de nenhuma das análises foram significantes, ou seja, os preditores empregados nos modelos de regressão não estão diretamente relacionados aos valores da multa 58 e \% multa 58 nos casos de TCE investigados no presente estudo. 


\section{Discussão}

Baseando-se no modelo econômico-comportamental operante para decisões em colegiado (cf. Estudo 1), o presente estudo teve o intuito de verificar se o colegiado onde o caso foi tramitado e se características relativas aos processos de TCE e influenciam as sanções propostas pelo relator. Portanto, para alcançar tais objetivos foram analisados casos referentes a processos de TCE distribuídos entre os três colegiados que compõem o TCU (1 ${ }^{\mathrm{a}}$ Câmara, $2^{\mathrm{a}}$ Câmara e Plenário).

Conforme é possível verificar na Tabela 15, a partir de uma análise de variância (ANOVA) e testes post hoc (Tukey's HSD) foram identificadas diferenças estatisticamente significantes entre as duas Câmaras e o Plenário para a maioria das variáveis que descrevem os processos de TCE, sendo que essas regularidades também foram corroboradas por análises nãoparamétricas (Kurskal-Wallis). No entanto, também vale destacar que tais regularidades não foram verificadas em comparações entre a $1^{\mathrm{a}}$ e $2^{\mathrm{a}}$ Câmara. Ou seja, é possível afirmar que existem diferenças significantes entre as medidas relacionadas a características do processo e das sanções que se referem aos processos de TCE tramitados no Plenário em comparação as duas Câmaras, mas não entre uma Câmara outra.

Uma das possíveis justificativas para as diferenças identificadas nos resultados entre as Câmaras e o Plenário pode estar diretamente relacionada a composição desses colegiados e seu papel na estrutura institucional do TCU. De acordo com o art. 9 do regimento interno do TCU (2015), o Plenário é composto por nove Ministros e suas sessões deliberativas devem ter um quórum de no mínimo 5 membros (cf. art. 93). Já no caso das Câmaras, o art. 134 determina que essas são compostas por 4 ministros, enquanto que o art. 134 estabelece que as suas sessões devem ter um quórum de pelo menos 3 membros. Também é necessário ressaltar que enquanto as 
Câmaras são compostas por membros distintos, o Plenário é composto pela soma dos membros das duas Câmaras e o Presidente do TCU. Ou seja, com exceção do Presidente do TCU, um mesmo membro de um colegiado (i.e., Ministro) atua tanto na Câmara a qual pertence, quanto no Plenário.

Nesse sentido, é possível comparar diretamente os colegiados do TCU com as cortes intermediárias e superiores da justiça americana que são frequentemente investigadas de modo comparado em trabalhos de análise econômica do direito (e.g., Epstein et al., 2011, 2013). Como essas cortes possuem características semelhantes quanto a sua composição, ritos e estrutura de funcionamento, é possível interpretar de modo análogo as regularidades que se aplicam ao contexto de decisão jurídico com o do TCU. Por exemplo, as cortes intermediárias possuem uma tamanho de colegiado menor, geralmente composta por três membros, enquanto instâncias superiores da justiça (e.g., Suprema Corte) possuem colegiados maiores (cf., Posner, 1995, 2007). Essa composição é semelhante a estrutura do TCU, e desse modo, a partir dessa analogia, é possível interpretar as Câmaras enquanto uma instância intermediária e o Plenário enquanto instancia superior em função do tamanho de seu colegiado. Ou seja, as regularidades atribuídas a diferenças de tamanho do colegiado entre decisões judiciais em instâncias intermediárias e superiores judiciais também podem ser empregadas para explicar diferenças nas decisões e características de processos entre as Câmaras e Plenário do TCU.

Em análise econômica do direito se verificou que o tamanho do colegiado está diretamente associado a tipos de padrão de decisão apresentado pelos magistrados (e.g., voto contra ou a favor do relator). De acordo com esses trabalhos, os colegiados menores tendem a estar associados a imposição de um custo social e instrumental mais elevado por uma decisão judicial mais controversa ou de se votar contra o relator do processo (cf. Epstein et al., 2011, 
2013, Posner, 1995, 2007). Ou seja, certos padrões de decisão serão menos prováveis em certos colegiados, pois resultam em um maior esforço e feedback social negativo pelos seus pares para ao magistrado.

Conforme é possível verificar na Tabelas 10, 11, 12 e 13, os valores médios para as medidas que se referem às multas baseadas nos artigos 57 e 58 foram menores para as Câmaras do que para o Plenário, e de acordo com as análises de variância que foram conduzidas (ver Tabela 15), tais diferenças entre os valores foram significantes para parte dos resultados. Portanto, a partir de tais evidências empíricas e das considerações teóricas apresentadas anteriormente é possível interpretar que os menores valores de multas podem estar relacionados diretamente as restrições impostas pelo cenário onde ocorreram as decisões, que são os colegiados.

Um outra possibilidade de interpretação da dinâmica entre os colegiados do TCU seria enquanto circuito jurídico, pois em um circuito, a partir de um grupo grande de magistrados são selecionados membros para compor colegiados menores, e em alguns casos até mesmo colegiados maiores para deliberar sobre casos mais importantes (cf. Kim, 200). Essa estrutura é semelhante em alguns pontos ao TCU, já que os membros das Câmaras são os mesmos que compõem o Plenário, o que geralmente ocorre em casos de maior relevância. No entanto, conforme foi constatado pelo estudo de Kim, em um estrutura de circuito, as decisões tendem a ser mais homogêneas entre colegiados. Ou seja, apesar do circuito compor diversos colegiados com membros que se repetem, as diferenças entre as suas decisões tendem a não apresentarem diferenças significantes, o que rejeita o modelo de circuito como uma analogia para a estrutura do TCU. 
Também é possível interpretar e explicar as diferenças entre as Câmaras e o Plenário no que se refere as análises dos processos de TCE em função das atribuições de cada um desses colegiados. Conforme está descrito no art. 17 do regimento interno do TCU (2015), as deliberações acerca de processos de TCE estão listadas como uma das atividades principais das duas Câmaras. Esse tipo de prevalência também é ressaltado pelo art. 137, que lista os processos de TCE em segundo lugar na ordem de preferência na pauta de atividades conduzidas durante as sessões nas Câmaras. Em primeiro lugar na pauta estão as deliberações sobre processos de recursos provenientes da própria Câmara, no entanto, tais processos de recursos também podem se referir a TCE. Já no art. 15 do regimento interno do TCU (2015), as deliberação sobre processos de TCE não está listada como uma de suas principais atribuições do Plenário. No entanto, assim como descrito pelos artigos 15, 139 e pelo $1^{\circ}$ parágrafo do art. 17, os processos de TCE podem ser evocados pelo Plenário ou remetidos pelo relator para esse colegiado em função da relevância de matéria do processo.

Como é possível verificar na Tabela 3, o número de processos de TCE que foram tramitados no Plenário foi cerca de $50 \%$ menor do que aqueles tramitados tanto na $1^{\text {a }}$ Câmara quanto na $2^{\mathrm{a}}$ Câmara em todas as amostras (e.g., amostra total: Plenário, 145; $1^{\mathrm{a}}$ amostra: 285; $2^{\mathrm{a}}$ amostra, 312). Ou seja, se identificou que a carga de trabalho no que se refere especificamente ao julgamento de processos de TCE foi maior nas Câmaras que a no Plenário. Desse modo, a identificação de uma quantidade inferior de processos de TCE tramitados no Plenário em relação as Câmaras, de fato descreve um contingência prevista pelo normativo.

Outro ponto que deve ser destacado, se refere a processos de TCE que são definidos como de sendo de matéria relevante serem remetidos ao Plenário (artigos 15, 139 e pelo $1^{\text {o }}$ parágrafo do art. 17). De acordo com o modelo proposto no Estudo 1 (ver Figura 2), é possível 
interpretar que a matéria relevante relacionada ao conteúdo do processo é um tipo de variável que agrega valor informativo as decisões relacionadas a tal processo, já que seu impacto social, político e institucional tende a ser mais significativo. Também vale a pena salientar que ao depender da natureza do processo, é prerrogativa tanto das Câmaras quanto do Plenário de declararem caráter sigiloso ao esse processo (Art. 97 e 134), de modo que seu conteúdo e deliberações não são abertas ao público. Ocorreram apenas oito processos de TCE sigilosos em todos os 742 casos analisados, no entanto, esses ocorreram de modo exclusivo no Plenário. Desse modo, tal resultado também enfatiza que os processos tramitados no Plenário tendem a estar relacionados a um maior valor informativo do que aqueles tramitados nas Câmaras.

Apesar dos resultados do presente estudo sugerirem que a dinâmica entre Plenário e Câmara apresenta semelhanças com as comparações entre instâncias intermediárias versus superiores da justiça (Epstein et al., 2011, 2013), a estrutura institucional do TCU apresenta algumas particularidades que merecem ser consideradas. Umas das principais distinções do Plenário do TCU em comparação a colegiados de instâncias superiores de justiça se refere a carga ou volume de trabalho. Tal como é destacando pela literatura de análise econômica do direito (e.g., Posner, 1995, 2007), cortes superiores tendem a ter uma carga de trabalho menor, o que acaba influenciando o comportamentos dos magistrados. Conforme é possível verificar na Tabela 3, apesar do Plenário ter uma carga de processos de TCE menor em relação as duas Câmaras, sua carga de trabalho total, o que inclui outras atribuições e deliberações sobre outros tipos de processo, é maior.

Uma variável proximal para carga de trabalho total de um colegiado pode ser medida a partir do número de sessões que esse teve ao longo do ano. Portanto, para verificar a frequência com a qual os colegiados se reúnem, foi verificado a partir de consulta ao website oficial do TCU 
o número de sessões que cada um colegiados teve no ano de 2016 (http://portal.tcu.gov.br /sessoes-pautas-e-atas/pautas/pautas-das-sessoes/list-pagination/2.htm). Apesar dos artigos 94 e 135 Regimento Interno do TCU (2015) determinarem que as duas Câmaras e o Plenário do TCU devem se reunir uma vez por semana, e os artigos 97 e 134 estipularem que esses colegiados tem a prerrogativa de marcar sessões extraordinárias, foram verificadas diferenças quanto ao número de sessões. O número total de sessões considerando os três colegiados no ano de 2016 foi de 181, sendo 95 para o Plenário, 45 para a $1^{\text {a }}$ Câmara e 43 para a $2^{\text {a }}$ Câmara. Desse modo, considerando o número de sessões em um ano como uma medida proximal para carga de trabalho total de um colegiado se identificou que o Plenário tem uma carga de trabalho superior, já que esse teve mais que o dobro que as sessões das duas Câmaras somadas.

Conforme já foi enfatizado na apresentação do modelo econômico comportamental operante para decisões em colegiado no Estudo 1 (cf. Figura 2), é possível interpretar o colegiado onde ocorre a deliberação sobre um processo de TCE enquanto uma variável de cenário. Desse modo, considerando os resultados empíricos aqui apresentados e os aspectos da estrutura institucional do TCU enquanto órgão colegiado destacados anteriormente, é possível concluir que as Câmaras possuem uma função de cenário relativamente aberto, e que o Plenário tem a função de cenário relativamente fechado. Essa interpretação se amparou principalmente na carga total de trabalho do Plenário ser maior, no fato desse deliberar sobre casos mais relevantes e pelas diferenças sistemáticas no resultados entre colegiados, sobretudo quanto as variáveis que mediram as sanções propostas pelos relatores em processos de TCE. Ou seja, existem diversas variáveis que atuam em conjunto impondo mais custos operacionais ou pressões sociais em decisões tramitadas no Plenário do que em relação as Câmaras. Tal como já foi amplamente relatado na literatura de economia comportamental operante, (e.g., Hursh, 1980, 1884), 
diferenças em padrões de comportamento também pode ser relacionadas ao cenário onde o comportamento ocorre, o que também ajuda a justificar as diferenças identificadas entre Câmaras e o Plenário.

Os comportamentos jurídicos analisados no presente trabalho foram as sanções propostas pelos relatores em processos de TCE, de modo que essas foram representadas por quatro variáveis contínuas (multa 57, \% multa 57, multa 58 e \% multa 58) e uma variável categórica (i.e., inabilitação). Para melhor avaliar a influência do colegiado (i.e, cenário), e como esse interage com outras variáveis relacionadas ao processo nas decisões propostas pelos relatores, foram realizadas análises de regressão linear empregando três modelos (Figura 3) para todas variáveis dependentes contínuas. Todas as análises de regressão apresentaram resultados significantes $(p<0,01)$, e enfatizaram que existem diferenças nos valores das sanções relacionadas ao art. 57 propostas pelo relator (multa 57, \% multa 57) em função do colegiado, enquanto que não foram identificados resultados significantes para as medidas que se referem a multa prevista pelo art. 58 .

No primeiro modelo de regressão foram inseridas cinco variáveis relacionadas a características do processo em conjunto com o colegiado onde ocorreu a decisão para verificar a sua influência sobre a sanção proposta pelo relator. No entanto, se verificou que apenas a variável montante do débito interagiu com o colegiado (i.e., cenário) para determinar o valor da variável multa 57. De modo mais específico, as análises indicaram que os processos com os maiores valores para a variável montante do débito (i.e., dano ao erário) e que transcorreram no Plenário obtiveram as maiores multas (ver também Tabela 10). Ou seja, as variáveis determinantes para o valor da multa foram o cenário da decisão, e o valor do débito, que no modelo proposto foi interpretado como uma consequência de nível utilitário, já que maiores 
valores de débito podem aumentar a carga de trabalho relacionada a um processo (e.g., exige a análise mais minuciosa do processo ou a inspeção de um maior número de documentos).

No que se refere a variável $\%$ multa 57 , essa se baseia diretamente no art. 57 da Lei $\mathrm{n}^{\circ}$ 8.443, de 1992 (lei orgânica do TCU, 2002), que estipula que o valor da multa deve ser baseado em uma porcentagem do valor do débito, que pode ser de $100 \%$ desse valor. Portanto, essa variável representa justamente o valor da multa em termos percentuais em relação ao dano ao erário cometido pelo gestor ou responsável por recursos públicos.

Diferentemente da regressão realizada para a variável dependente multa 57, onde apenas o montante do débito interagiu com o colegiado para determinar o valor da multa, na regressão para a variável \% multa 57 os coeficientes para acórdãos total também foram significantes em pelo menos duas amostras $(p<0,05)$. Os coeficientes para essa variável foram negativos, indicando que quanto mais acórdãos um processo produziu, menores foram os valores percentuais da multa baseada no art. 57. De acordo com o modelo proposto no Estudo 1 o número de acórdãos de um processo está relacionado a consequências utilitárias (i.e., custo ou esforço), pois quanto mais acórdãos um processo produz, maior a carga de trabalho imposta em um colegiado devido a esse processo (e.g., mais sessões para deliberar, mais material de leitura). Portanto, apesar desse regularidade se restringir apenas a essa análise, também se verificou que outro tipos de consequências utilitárias podem estar relacionadas aos valores percentuais da multa prevista pelo art. 57, no entanto, tais interações devem ser melhor exploradas em estudos futuros.

Assim como verificado para a variável multa 57 (valor absoluto da multa) os coeficientes encontrados foram negativos nas comparações entre as duas Câmaras e o Plenário, indicando que os maiores valores foram verificados no Plenário. No entanto, no que se refere ao montante do 
débito, se verificou um padrão oposto, pois os coeficientes foram negativos, indicando que os processos com maiores valores de débito, na verdade possuíram menor valor percentual de multa prevista pelo art. 57.

Tomando em conjunto as análises para as variáveis multa 57 e \% multa 57 em relação as características do processo ( $1^{\circ}$ modelo de regressão, ver figura 3$)$, foi possível constatar que apesar dos processos onde constam os maiores danos ao erário terem obtido os maiores para multa baseada no art. 57 em termo absolutos (i.e., relação positiva entre os coeficientes), esses tiveram os menores valores percentuais de multa (i.e., relação negativa entre os coeficientes). Ou seja, os dados sugerem que os casos com maiores danos ao erário foram, em termos relativos, proporcionalmente punidos de forma mais branda (menor valor percentual da multa em relação ao débito.

O segundo modelo de regressão investigou a influência do tipo de atos infracionais cometido pelo gestor de recursos públicos sobre o valor da multa baseada no art. 57 em processos de TCE (i.e., motivo de instauração). Esses atos infracionais são definidos pelo inciso III do art. 16 do Regimento interno do TCU (2015) e são divididos em quatro categorias (ver Tabela 1). De acordo com o modelo proposto no Estudo 1, os atos infracionais descritos em forma de lei tem a função de estímulo discriminativo para o comportamento dos relatores do processo de TCE. Ou seja, mediante a identificação de determinado ato infracional o comportamento do relator de propor uma certa sanção para o caso é evocado seguindo os parâmetros dessa lei.

Os resultados das regressões para as variáveis multa 57 e \% multa 57, apresentaram coeficientes significantes e negativos para a maior parte dos casos nas comparações com o ato infracional descrito pela alínea "d" (desfalque ou desvio de dinheiros, bens ou valores públicos). 
Portanto, os dados sugerem que esse tipo de ato infracional foi mais severamente punido do que os atos ou combinação de atos descritos pelas demais alíneas. Ou seja, o ato de desfalcar recursos públicos obteve as maiores multas em termos absolutos (multa 57) e percentuais (\% multa 57), indicando que esse crime foi considerado mais grave pelos relatores, sobretudo no Plenário (ver Tabelas 17 e 20).

Tal análise é complementada pelos dados descritivos, pois de acordo com a Tabela 6, o ato infracional descrito pela alínea "d" foi mais frequente no Plenário do que nas duas Câmaras. Desse modo, é possível interpretar que o ato de desfalcar recursos públicos tende a ser mais relevante e de fato mais grave, pois conforme foi discutido anteriormente, os processos com matéria de maior relevância ou de conteúdo sensível podem ser encaminhados para o Plenário ou evocados por ele. Por fim, baseando-se no modelo proposto pelo Estudo 1 a relevância de um caso pode ser interpretadas em termos de consequências informativas, já que esse tende produzir um maior impacto social, político e institucional.

O terceiro modelo de regressão empregado no presente estudo testou se cargo do gestor que cometeu o dano ao interage com o colegiado onde o processo foi tramitado para influenciar os valores relacionados a multa prevista pelo art. 57 proposta pelos relatores de processos de TCE (multa 57 e \% multa 57). De acordo com o modelo proposto no Estudo 1, o cargo ocupado pelo gestor que cometeu a infração é considerada uma variável relacionada a consequências informativas, já que infrações cometidas por prefeitos tendem a apresentar um impacto social e institucional maior do que aquelas cometidas por um funcionário público ou um tesoureiro.

Não foram encontradas análises consistentes relacionando o cargo do gestor com a variável \% multa 57, no entanto, conforme está exposto nas Tabela 18, foram verificados coeficientes significantes $(\mathrm{p}<0,01)$ e positivos em duas amostras nas comparações entre outros 
cargos (e.g., funcionários públicos, tesoureiros, bolsistas) vs. prefeitos. Ou seja, as análises sugeriram que o valor absoluto da multa prevista pelo art. 57 tende a ser relativamente menor para prefeitos do que para gestores de recursos públicos que ocupam cargos com potencial menor de impacto social. Apesar desses dados não terem apresentado a mesma robustez das análises anteriores, eles sugerem que o impacto político de se impor uma multa mais severa em um político, ou seja, alguém em um cargo de maior poder, pode funcionar como uma punição informativa para os relatores do processo, e, portanto, existe a tendência de se propor multas relativamente mais brandas.

Por fim, também vale a pena destacar os dados descritivos acerca das sanções previstas pelos art. 57 e 58 da lei orgânica do TCU (2002). As Tabelas 11 e 13 contém os valores médios relativos as variáveis \% multa 57 e \% multa 58 e tomando como referência a amostra total, verificou-se que os valores percentuais médios em todos os colegiados foram todos inferiores a 20\% (1 ${ }^{\text {a }}$ Câmara: 16,94\%; $2^{\text {a }}$ Câmara: 14,62\%; Plenário: 19,76\%). Especificamente no que se refere a multa prevista pelo art. 57, apesar da lei estipular que tais multas podem se referir a até $100 \%$ do valor do débito, apenas em dois casos se verificou esse valor. Mesmo tomando como referência um valor de pelo menos $50 \%$ do débito, ocorreram somente 25 dos 742 casos analisados. Esses dados também sugerem que multas com valores percentuais relativamente altas podem estar relacionadas a punições informativas e utilitárias, e por isso tendem a ser evitadas pelos relatores.

Considerando os resultados descritivos e inferenciais, é possível interpretar a partir do modelo proposto no Estudo 1 que multas com percentuais altos podem estar associadas a punições utilitárias e sobretudo informativas para os relatores. Empregando a amostra total como referência, entre 40,7\% e 51,3\% dos processos analisados se referem a casos envolvendo 
prefeitos, e como esses tendem a ter influência política e social, adotar multas muito altas em termos percentuais podem acarretar em feedback social, político e institucional negativo para os relatores (punição informativa).

Desse modo, em virtude da lei estipular critérios vagos para o valor da sanção, essa acaba sendo pouco eficiente em descrever parâmetros claros para direcionar o comportamento dos relatores de propor os valores das sanções. Desse modo, conforme os resultados sugerem, em função de evitar punições informativas e utilitárias os relatores acabam adotando um valor percentual relativamente baixo, ou seja, uma outra contingência acaba se estabelecendo e sobrepondo aquela descrita pela lei. Tal regularidade exemplifica o que Aguiar (2006, 2013, 2014) destaca como diferenças entre as contingências programadas (i.e., texto da lei) e contingências vigentes (i.e., o que de fato ocorre), e enfatiza que a formulação de leis e normativos podem se beneficiar de estudos empíricos para testar a sua eficiência.

Por fim, no que se refere a sanção de inabilitação, a análise de variância e testes post hoc (ver Tabela 15) identificaram diferenças significantes quanto a sua ocorrência entre o Plenário e as duas Câmaras. No entanto, em função do número reduzido de ocorrências dessa sanção (amostra total: 37 no Plenário, 9 na $1^{\text {a }}$ Câmara e 3 na $2^{\text {a }}$ Câmara) não foram conduzidas outras análises inferenciais (i.e., regressões) para investigar essa sanção. Apesar disso, a partir das análises descritivas e de variância (ANOVA) foram verificados dados relevantes acerca dessa sanção, já que essa ocorreu com uma frequência muito superior em processos tramitados no Plenário do que nas duas Câmaras em todas as amostras (ver Tabela 14).

De acordo com o art. 270 do regimento Interno do TCU (2015), a sanção de inabilitação é aplicada apenas em casos de alta gravidade, de modo que a gravidade de um caso deve ser determinada por voto pela maioria dos membros do Tribunal. Novamente, a determinação da 
gravidade do caso pode ser interpretada em termos de consequências informativas e utilitárias, já que os casos com mais impacto social e envolvendo maiores somas tendem a ser punidos com tal sanção. O fato da sanção de inabilitação ocorrer de modo muito mais prevalente no Plenário também reforça o argumento de que os processos tramitados nesse colegiado possuem uma carga maior de consequências informativas e utilitárias do que aqueles tramitados na duas Câmaras.

Em função de sua relevância na literatura de análise econômica do direito como o padrão de comportamento jurídico mais estudado, também foram coletados dados acerca dos votos emitidos no colegiado em relação a proposta de sanção do relator (i.e., concordar ou discordar). Como foi descrito no método, os dados empregados no presente estudo foram extraídos de acórdãos que continham deliberações do colegiado acerca de processos de TCE. De acordo com esses acórdãos, com exceção dos casos que foram declarados sigilosos, de modo que a informação sobre os votos não estava acessível, todos os casos analisados apresentaram unanimidade de votos à favor da proposta do relator a despeito do colegiado, e em função disso, tais dados não foram analisados e relatados na seção de resultados.

O fato de todos os casos terem apresentado unanimidade de votos a favor levanta questões acerca da confiabilidade desses dados, pois sugere a possibilidade dos votos simplesmente não terem sido descritos de modo detalhado e preciso, pois os relatos nos acórdãos não são completamente sistemático quanto a esses aspecto específico da deliberação. Em relação aos votos emitidos em função da proposta de sanção pelo relator, foi comum encontrar as seguintes informações: “os Ministros acordam” ou “os Ministros acordam em unanimidade”. No entanto, em nenhum dos acórdãos analisados constaram informações detalhadas acerca do voto que cada um dos Ministros ou Ministros-substitutos envolvidos na deliberação proferiu. Ou seja, de fato pode ter ocorrido unanimidade em todos os casos, ou simplesmente existe uma prática 
institucional que envolve não relatar em detalhe tais informações. De qualquer maneira, a fim de identificar qual das possibilidades representam a realidade do TCU, tal fenômeno precisa ser melhor investigado.

A unanimidade em todos os casos também levanta questões quanto a relevância e viabilidade de se estudar esse fenômeno em particular em casos de TCE no TCU. Se de fato a unanimidade ocorre de modo generalizada, simplesmente não é possível investigar variáveis relacionadas aos votos emitidos pelos membros do colegiado, já que não existe variação. Ou seja, a despeito das características do processo e do colegiado onde esse transcorreu, o voto sempre será a favor da proposta do relator. Novamente em função dessa ausência de variação em função de variáveis contextuais, a análise dos votos emitidos para uma sanção enquanto comportamento de escolha de magistrados também perde a sua relevância enquanto fenômeno.

Apesar de não ter sido analisada em detalhe como as sanções (e.g., multa baseada no art. 57), e da possibilidade dos dados não serem confiáveis, é possível sugerir algumas interpretações para esse padrão de unanimidade generalizada a partir do modelo proposto no Estudo 1. Estabelecendo uma comparação com estudos de análise econômica do direito, a unanimidade representaria um padrão extremo de aversão a dissenção, pois até mesmo em instâncias intermediárias da justiça, que possuem colegiados menores (e.g., Epstein 2011), alguma frequência de discordância tende a ocorrer.

A partir disso, seria possível inferir que as consequências utilitárias e sobretudo informativas relativas a dissentir (i.e., votar contra o relator) sejam maiores no contexto do TCU do que em cortes de justiça. Portanto, no contexto do TCU a punição informativa por emitir um voto discordante pode vir na forma de feedback negativo dos outros membros do colegiado. No que se refere a punição utilitária, essa pode ser representada pelo custo, esforço e tempo gasto em 
função de um eventual aumento de tempo de duração da deliberação sobre o caso. Além disso, a punição utilitária também estaria associada a um aumento da carga de trabalho em função do voto discordante, já que uma nova proposta de sanção deverá ser redigida e votada no caso do processo não ser aprovado. Desse modo, a partir dessa interpretação, a magnitude desses punidores utilitários e informativos seriam tão altos, que a dissenção simplesmente não ocorre em casos de TCE no TCU. Novamente é necessário salientar que são necessários estudos posteriores para investigar melhor esse fenômeno e verificar se tais dados são precisos.

\section{Estudo 3}

Em um estudo de cunho teórico Foxall (2004) apresenta uma proposta de investigar diferenças em padrões de decisão em colegiado em função de categorias dos estilos cognitivos ou intelectuais de cada magistrado. De acordo com o autor, esses estilos cognitivos são amplamente frequentes em todas as populações e se referem a forma como um indivíduo aborda decisões e resolução de problemas, dividindo-se em basicamente dois tipos: inovadores, que tendem a buscar soluções diferentes, e adaptadores, que prezam abordagens mais conservadoras. Esse tipo de interpretação e classificação dos magistrados em função de características cognitivas demonstra a possibilidade de investigar como diferenças individuais que podem estar relacionadas ao histórico de aprendizagem dos membros dos colegiados e como essas podem influenciar as suas decisões de modo significativo.

Como já foi demonstrado anteriormente, uma das variáveis frequentemente investigadas na literatura de análise econômica do direito se refere a ideologia dos magistrados que compõem um colegiado (e.g., Clark \& Lauderdale, 2012; Epstein et al., 2013; Kim, 2009; Sisk \& Heise, 2005). Muitos desses estudos analisam decisões colegiadas da Suprema Corte americana (Supreme Court), onde adotam como medida proxy para ideologia o partido político do 
Presidente que indicou o Juiz ao cargo, que pode ser democrata ou republicano. De modo simplificado, esses estudos analisam a tendência dos membros do colegiado de concordar ou discordar com a decisão do relator do processo em função desses compartilharem ou não a mesma ideologia. A análise dos estudos citados acima, permite constatar que tradicionalmente em análise econômica do direito a ideologia tende a ser interpretada como uma variável que pode interagir e interferir em decisões de colegiado enquanto grupo. Isso costuma ser verificado na medida em que são emitidos votos concordando ou discordando da sentença emitida pelo relator do processo.

Como os estudos de análise econômica do direito sobre decisões de magistrados trabalham quase que exclusivamente com dados agregados e tendem a analisar a decisão de grupos (i.e., colegiado) em detrimento de indivíduos, a ideologia não é diretamente investigada enquanto uma característica individual do relator (i.e., Ministro ou Magistrado). Ou seja, por investigarem decisões do grupo, tais estudos não interpretam a ideologia como uma variável associada a diferenças individuais no relator. Nesse sentido, pode ser vantajoso para esse campo de estudo interpretar a ideologia em um sentido disposicional (i.e., Se - Então), de modo que essa pode estar associada a certos padrões de decisão. Ou seja, interpretar a ideologia como uma variável relativa ao histórico de aprendizagem de comportamentos jurídicos, e como isso pode estar associado a identificação de diferenças individuais nas características das decisões emitidas pelo relatores dos processos. Nesse sentido, investigar outras variáveis que podem ser descritas em termos de histórico de aprendizagem de comportamentos jurídicos também pode apresentar resultados relevantes.

Tal tipo de investigação também encontra suporte na proposta de Aguiar (2006) que critica a postura teórica e metodológica de estudos de análise econômica do direito como os de 
Posner (1995) e Epstein et al. (2013), justamente por não investigarem de modo mais específico as variáveis presentes nas contingências jurídicas relacionadas as decisões judiciais. Nesse sentido, investigar variáveis relacionadas a histórico de aprendizagem de comportamentos jurídicos, é essencial para compreender decisões de magistrados ou ministros de modo mais preciso. Isso pode ser realizado na medida em que se identifica e analisa a função de tais variáveis em contextos de decisão judicial mais específicos (i.e, contingência jurídica), tais como o contexto dos processos de TCE.

O Estudo 2 investigou regularidades acerca das decisões de relatores em processos de TCE em função do colegiado onde este transcorreu, que a partir do modelo proposto no Estudo 1 (ver figura 2) foi interpretado como um antecedente de cenário. Já o presente estudo irá se focar em outro tipo de variável antecedente ao comportamento jurídico, e também na identificação de diferenças individuais nas decisões dos relatores. Desse modo, o presente estudo tem dois objetivos: (1) verificar a influência de variáveis relacionadas ao histórico de aprendizagem de decisões jurídicas em diferenças nas sanções estabelecidas pelos relatores em processos de TCE; (2) e verificar se os diferentes relatores responsáveis por processos de TCE, que podem ser Ministros ou Ministros-substitutos, apresentam diferenças significantes em suas decisões (i.e., valores e tipos das sanções) em relação um ao outro. Ou seja, foi investigado se a despeito de estarem trabalhando com processos amparados pelas mesmas leis, se existem diferenças individuais nas sanções em função do histórico de aprendizagem e por elas terem sido emitidas por relatores distintos.

Enquanto que a literatura tradicional de análise econômica do direito (e.g., Epstein et al., 2013) tende a se referir apenas a ideologia enquanto uma variável que pode ser interpretada em termos de aprendizagem, o presente estudo propõe outro tipo de variável. Como é possível 
verificar no Estudo 1 (ver Figura 2), no presente estudo foram determinadas duas categorias de variáveis: o tipo de cargo atual do relator (cargo do relator) e o tipo de cargo anterior do relator do processo (cargo anterior do relator). Portanto, de modo mais específico, serão investigadas duas variáveis relacionadas ao histórico de aprendizagem dos relatores: O seu cargo atual (i.e., Ministro ou Ministro-substituto) e o tipo de cargo anteriormente ocupado antes de sua nomeação como Ministro ou Ministro-substituto (i.e., político ou técnico). Ou seja, se investigou se os diferentes tipos de cargo ou de origem profissional estão associados a diferenças em padrões de decisão dos relatores em processos de TCE, na medida em que esses podem estar associados a obtenção de certos tipos de consequências (informativas ou utilitárias) em detrimento de outras.

Investigar diferenças individuais dos relatores do processo em decisões em colegiado pode ajudar a tornar os estudos da área mais diretamente ligados com a prática jurídica de fato do que apenas a concepções teóricas. Tal como Cameron e Kornhauser (2015) destacam, muitos estudos de análise econômica do direito empregam variáveis preditoras de modo muito amplo e sem adequá-la de modo mais preciso ao contexto específico do tipo do processo (e.g., criminal ou trabalhista). Portanto, a classificação e investigação mais precisa de variáveis de histórico de aprendizagem de comportamentos jurídicos pode ajudar a identificar fatores essenciais as características das decisões propostas pelos relatores. Por fim, a investigação de diferenças em padrões de decisão de relatores em nível de análise individual em um tipo específico de processo, também ajuda a dirimir as questões levantadas acima e representa um perspectiva original e mais alinhada com a análise tipicamente realizada em um perspectiva psicológica.

\section{Método}

Banco de dados e materiais. Para a realização do presente estudo, foi empregado o mesmo banco de dados e materiais que do Estudo 2. A única exceção se refere ao material 
biográfico e institucional sobre Ministros e Ministros-substitutos do TCU que foi consultado como principal fonte para classificar os cargos anteriores dos relatores e identificar o cargo do relator em Ministro ou Ministro-substituto. Tal material biográfico se encontra em sobretudo uma publicação específica do TCU (cf., TCU, 2008) e no website oficial do órgão (TCU, 2016).

Procedimento e Análise de dados. De maneira geral, o presente estudo adotou um procedimento semelhante ao que foi empregado no Estudo 2. No entanto, foi necessário realizar a identificação dos cargos e classificação do tipo de cargo anterior ocupado pelos relatores, para investigar como essas variáveis podem estar relacionadas as decisões realizadas em processos de TCE.

Quanto aos cargos dos relatores, existem dois tipos descritos no Regimento Interno do TCU (2015): Ministro e Ministro-substituto. Para a determinação do cargo, primeiramente foi realizada a identificação do nome do relator do primeiro acórdão de decisão. A partir disso, verificou-se no organograma do TCU (TCU, 2016) ou no material biográfico relativo aos Ministros (TCU, 2008) o cargo que o relator ocupava no momento da decisão. Vale a pena destacar que alguns dos Ministros identificados no banco de dados já se encontram aposentados, enquanto que todos os Ministros-substitutos se encontram em atividade.

No que concerne ao tipo de cargo ocupado anteriormente pelo relator, foram definidas duas categorias: político e técnico. Como técnico foram considerados aqueles relatores que antes de sua nomeação como Ministro ocuparam cargos de analista jurídico da Câmara ou senado, analista do TCU, representante do Ministério Público junto ao TCU ou que tenham exercido função de Ministro-Substituto antes de serem nomeados como Ministro. Além disso, todos os Ministros-substitutos foram considerados como pertencentes a categoria técnico. Tal critério se baseou nos requerimentos estabelecidos de seleção para o cargo via concurso público, onde é 
necessária a comprovação de alto nível de conhecimento jurídico e de extensa experiência nesse âmbito (cf. Regimento Interno do TCU, 2015).

No que concerne à categoria de cargo anterior classificada como político, foram considerados aqueles que antes de sua nomeação como Ministros ocuparam cargos de confiança em estatais, órgãos do governo federal e estadual ou Ministérios. Além disso, também foram considerados de origem política aqueles Ministros que exerceram mandatos como Deputado Federal ou Senador.

Ainda de modo semelhante ao anterior (Estudo 2), no presente estudo foram realizadas os mesmo tipos de análises descritivas e inferências. Porém, tais análises visaram evidenciar regularidades acerca do cargo do Relator ou tipo de cargo anterior ocupado por ele, em detrimento de investigar a influência do tipo de colegiado em que o processo transcorreu.

Por fim, a parte final desse estudo consistiu em investigar se existem diferenças significantes nas características dos processos e sobretudo nas sentenças emitidas pelos entre os diferentes relatores em comparações individuais. Conforme será melhor detalhado na seção de resultados, para alcançar tal objetivo foram realizadas comparações entre as médias das medidas obtidas para cada um dos relatores a partir de análises paramétrica e não-paramétricas (ANOVA e Kruskal-Wallis).

\section{Resultados}

A apresentação dos resultados segue a mesma estrutura de organização empregada no Estudo 2. Primeiramente foram descritos os resultados para o tipo de cargo do relator e posteriormente as análises referentes ao tipo de cargo anterior. 
Cargo do relator. As análises referentes ao nível de análise de cargo do relator seguiu os mesmos parâmetros e estrutura daquelas realizadas para colegiado (Estudo 2). Primeiramente estão apresentadas as análises descritivas.

Composição dos colegiados. A tabela 21 mostra o número de Ministros e Ministrossubstitutos que compõem os colegiados do TCU em todos os processos analisas em todas amostras. Os dados indicaram que os Ministro-substitutos dos processos analisados são os mesmo que compõem o TCU atualmente, desse modo, o número máximo foi de quatro em todos os colegiados.

Tabela 21

Frequência (e porcentagem) de relatores responsáveis por acórdãos de decisão em processos de TCE em função do cargo do relator em todos colegiados e amostras

\begin{tabular}{|c|c|c|c|c|c|c|c|c|c|}
\hline \multirow[b]{2}{*}{$\begin{array}{l}\text { Cargo do } \\
\text { relator }\end{array}$} & \multicolumn{3}{|c|}{$1^{\text {a }}$ Câmara } & \multicolumn{3}{|c|}{$2^{\text {a }}$ Câmara } & \multicolumn{3}{|c|}{ Plenário } \\
\hline & $\begin{array}{c}\text { Amostra } \\
1\end{array}$ & $\begin{array}{c}\text { Amostra } \\
2\end{array}$ & $\begin{array}{c}\text { Amostra } \\
\text { total }\end{array}$ & $\begin{array}{c}\text { Amostra } \\
1\end{array}$ & $\begin{array}{c}\text { Amostra } \\
2\end{array}$ & $\begin{array}{c}\text { Amostra } \\
\text { total }\end{array}$ & $\begin{array}{c}\text { Amostra } \\
1\end{array}$ & $\begin{array}{c}\text { Amostra } \\
2\end{array}$ & $\begin{array}{c}\text { Amostra } \\
\text { total }\end{array}$ \\
\hline \multirow[b]{2}{*}{ Ministro } & 13 & 12 & 14 & 12 & 11 & 12 & 12 & 10 & 12 \\
\hline & $(81,3)$ & (75) & $(77,8)$ & (80) & $(78,6)$ & (80) & (80) & $(71,4)$ & (75) \\
\hline \multirow{2}{*}{$\begin{array}{l}\text { Ministro- } \\
\text { Substituto }\end{array}$} & 3 & 4 & 4 & 3 & 3 & 3 & 3 & 4 & 4 \\
\hline & $(18,8)$ & $(25)$ & $(22,2)$ & (20) & $(21,4)$ & (20) & (20) & $(28,6)$ & $(25)$ \\
\hline \multirow{2}{*}{ Total } & 16 & 16 & 18 & 15 & 14 & 15 & 15 & 14 & 16 \\
\hline & (100) & (100) & (100) & (100) & (100) & (100) & (100) & (100) & (100) \\
\hline
\end{tabular}

Nota. $N=$ Amostra 1: 371; Amostra 2: 371; Amostra total: 742 .

Distribuição dos processos de TCE. Na Tabela 22 estão apresentados os dados relacionados a distribuição dos processos em função do cargo do relator, indicando que os valores absolutos de processos para os Ministros é maior. No entanto, em termos proporcionais, o número de processos foi maior por Ministro-substituto. Usando como referência a amostra completa, a distribuição dos processos aproximadamente de 13 para cada Ministro e de 24 por 
cada Ministro-substitutos na $1^{\text {a }}$ Câmara, 16 para cada Ministro e 31 por Ministro-Substituto na $2^{\text {a }}$ Câmara, e de oito para cada Ministro e 11 por Ministro-substituto. Apesar de ser uma medida aproximada, essa serviu de indicativo de que a carga específica de processos de TCE para Ministros-substitutos foi relativamente maior do que para Ministros nos casos analisados.

Tabela 22

Frequência (e porcentagem) de acórdãos de decisão emitidos em processos de TCE em função do cargo de ocupado pelo relator em todos colegiados e amostras

\begin{tabular}{|c|c|c|c|c|c|c|c|c|c|}
\hline \multirow[b]{2}{*}{$\begin{array}{l}\text { Cargo do } \\
\text { relator }\end{array}$} & \multicolumn{3}{|c|}{$1^{\text {a }}$ Câmara } & \multicolumn{3}{|c|}{$2^{\mathrm{a}}$ Câmara } & \multicolumn{3}{|c|}{ Plenário } \\
\hline & $\begin{array}{c}\text { Amostra } \\
1\end{array}$ & $\begin{array}{c}\text { Amostra } \\
2\end{array}$ & $\begin{array}{c}\text { Amostra } \\
\text { total }\end{array}$ & $\begin{array}{c}\text { Amostra } \\
1\end{array}$ & $\begin{array}{c}\text { Amostra } \\
2\end{array}$ & $\begin{array}{c}\text { Amostra } \\
\text { total }\end{array}$ & $\begin{array}{c}\text { Amostra } \\
1\end{array}$ & $\begin{array}{c}\text { Amostra } \\
2\end{array}$ & $\begin{array}{c}\text { Amostra } \\
\text { total }\end{array}$ \\
\hline \multirow[b]{2}{*}{ Ministro } & 102 & 86 & 188 & 79 & 109 & 188 & 60 & 40 & 100 \\
\hline & $(67,5)$ & $(64,2)$ & (66) & $(55,2)$ & $(64,5)$ & $(60,3)$ & $(77,9)$ & $(58,8)$ & (69) \\
\hline \multirow{2}{*}{$\begin{array}{l}\text { Ministro- } \\
\text { Substituto }\end{array}$} & 49 & 48 & 97 & 64 & 60 & 124 & 17 & 28 & 45 \\
\hline & $(32,5)$ & $(35,8)$ & (34) & $(44,8)$ & $(35,5)$ & $(39,7)$ & $(22,1)$ & $(41,2)$ & $(31)$ \\
\hline \multirow{2}{*}{ Total } & 151 & 134 & 285 & 143 & 169 & 312 & 77 & 68 & 145 \\
\hline & (100) & (100) & (100) & (100) & (100) & (100) & (100) & (100) & (100) \\
\hline
\end{tabular}

Nota. $N=$ Amostra 1: 371; Amostra 2: 371; Amostra total: 742.

Variáveis relacionadas aos processos de TCE. No que se refere ao tipo de cargo do gestor ou responsável que foi julgado nos processos de TCE em que Ministro ou MinistrosSubstitutos foram relatores, os resultados estão dispostos na Tabela 23. Considerando todas as amostras, não se identificaram claras diferenças em função do cargo relator e novamente se enfatiza que a categoria Prefeito ou Secretário foi a mais envolvida em processos de TCE. 
Tabela 23

Frequência (e porcentagem) de processos de TCE em função do cargo de ocupado pelo gestor ou responsável por fundos públicos em função do cargo ocupado pelo relator em todas as amostras

\begin{tabular}{lcccccccc}
\hline & \multicolumn{3}{c}{ Ministro $^{a}$} & & \multicolumn{3}{c}{ Ministro-substituto $^{a}$} \\
\cline { 2 - 4 } \cline { 6 - 8 } Cargo do responsável & Amostra & Amostra & Amostra & & Amostra & Amostra & Amostra \\
total & & 1 & 2 & total \\
\hline Prefeito ou Secretário & 116 & 105 & 221 & & 69 & 64 & 133 \\
& $(48,1)$ & $(44,7)$ & $(46,4)$ & & $(53,1)$ & $(47,1)$ & $(50)$ \\
Presidente ou Diretor & 42 & 51 & 93 & & 20 & 30 & 50 \\
& $(17,4)$ & $(21,7)$ & $(19,5)$ & & $(15,4)$ & $(22,1)$ & $(18,8)$ \\
Outros cargos & 46 & 43 & 89 & & 26 & 29 & 55 \\
& $(19,1)$ & $(18,3)$ & $(18,7)$ & & $(20)$ & $(21,3)$ & $(20,7)$ \\
Dados faltantes & $a$ & 37 & 36 & 73 & & 15 & 13 & 28 \\
& $(15,4)$ & $(15,3)$ & $(15,3)$ & & $(11,5)$ & $(9,6)$ & $(10,5)$ \\
\hline Total & 241 & 235 & 476 & & 130 & 136 & 266 \\
& $(100)$ & $(100)$ & $(100)$ & & $(100)$ & $(100)$ & $(100)$ \\
\hline
\end{tabular}

Nota. $N=$ Amostra 1: 371; Amostra 2: 371; Amostra total: 742. ${ }^{a}$ Dados faltantes se referem tanto a ausência de informações disponível nos acórdãos de decisão quanto a casos sigilosos.

A Tabela 24 contém a distribuição dos processos em função da região do Brasil. Novamente não se verificaram diferenças claras em função do cargo do relator (em termos percentuais), e os estados com o maior número de ocorrências foram Maranhão, São Paulo, Minas Gerais e Rio de Janeiro. 
Tabela 24

Frequência (e porcentagem) de processos de TCE por região do Brasil da unidade federativa onde ocorreu a irregularidade em função do cargo do relator em todas as amostras

\begin{tabular}{|c|c|c|c|c|c|c|}
\hline \multirow[b]{2}{*}{ Região do Brasil } & \multicolumn{3}{|c|}{ Ministro $^{a}$} & \multicolumn{3}{|c|}{ Ministro-substituto $^{a}$} \\
\hline & $\begin{array}{c}\text { Amostra } \\
1\end{array}$ & $\begin{array}{c}\text { Amostra } \\
2 \\
\end{array}$ & $\begin{array}{c}\text { Amostra } \\
\text { total }\end{array}$ & $\begin{array}{c}\text { Amostra } \\
1 \\
\end{array}$ & $\begin{array}{c}\text { Amostra } \\
2\end{array}$ & $\begin{array}{c}\text { Amostra } \\
\text { total }\end{array}$ \\
\hline Centro-Oeste & $\begin{array}{c}27 \\
(11,2)\end{array}$ & $\begin{array}{c}37 \\
(15,7)\end{array}$ & $\begin{array}{c}64 \\
(13,4)\end{array}$ & $\begin{array}{c}21 \\
(16,2)\end{array}$ & $\begin{array}{c}21 \\
(15,4)\end{array}$ & $\begin{array}{c}42 \\
(15,8)\end{array}$ \\
\hline Nordeste & $\begin{array}{c}84 \\
(34,9)\end{array}$ & $\begin{array}{c}68 \\
(28,9)\end{array}$ & $\begin{array}{c}152 \\
(31,9)\end{array}$ & $\begin{array}{c}58 \\
(44,6)\end{array}$ & $\begin{array}{c}69 \\
(50,7)\end{array}$ & $\begin{array}{c}127 \\
(47,7)\end{array}$ \\
\hline Norte & $\begin{array}{c}43 \\
(17,8)\end{array}$ & $\begin{array}{c}40 \\
(17)\end{array}$ & $\begin{array}{c}83 \\
(17,4)\end{array}$ & $\begin{array}{c}20 \\
(15,4)\end{array}$ & $\begin{array}{c}21 \\
(15,4)\end{array}$ & $\begin{array}{c}41 \\
(15,4)\end{array}$ \\
\hline Sudeste & $\begin{array}{c}66 \\
(27,4)\end{array}$ & $\begin{array}{c}72 \\
(30,6)\end{array}$ & $\begin{array}{l}138 \\
(29)\end{array}$ & $\begin{array}{c}18 \\
(13,8)\end{array}$ & $\begin{array}{c}14 \\
(10,3)\end{array}$ & $\begin{array}{c}32 \\
(12)\end{array}$ \\
\hline Sul & $\begin{array}{c}21 \\
(8,7)\end{array}$ & $\begin{array}{c}18 \\
(7,7) \\
\end{array}$ & $\begin{array}{c}39 \\
(8,2) \\
\end{array}$ & $\begin{array}{c}13 \\
(10) \\
\end{array}$ & $\begin{array}{c}11 \\
(8,1)\end{array}$ & $\begin{array}{l}24 \\
(9) \\
\end{array}$ \\
\hline Total & $\begin{array}{c}241 \\
(100)\end{array}$ & $\begin{array}{c}235 \\
(100)\end{array}$ & $\begin{array}{c}476 \\
(100)\end{array}$ & $\begin{array}{c}130 \\
(100)\end{array}$ & $\begin{array}{c}136 \\
(100)\end{array}$ & $\begin{array}{c}266 \\
(100)\end{array}$ \\
\hline
\end{tabular}

Nota. $N=$ Amostra 1: 371; Amostra 2: 371; Amostra total: 742.

A Tabela 25 apresenta a distribuição de processos de TCE em função do motivo de instauração para Ministros e Ministros-substitutos, e modo geral, os valores foram bem próximos em termos percentuais para os dois cargos de relator. A única diferença mais notável foi referente aos casos relacionados a alínea "d” (desfalque ou desvio de dinheiros, bens ou valores públicos), onde se verificou um valor percentual bem menor para Ministros-substitutos do que para ministros (cerca de $7 \%$ contra 13\%). Os resultados também indicaram que as categorias alínea “c” (dano ao erário decorrente de ato de gestão ilegítimo ao antieconômico) e mais de um ato foram as mais prevalentes em todas as amostras. 
Tabela 25

Frequência e porcentagem de motivos de instauração de processo de TCE em função do relator em todas as amostras

\begin{tabular}{|c|c|c|c|c|c|c|}
\hline \multirow[b]{2}{*}{$\begin{array}{l}\text { Motivo de instauração - } \\
\text { Alínea }\end{array}$} & \multicolumn{3}{|c|}{ Ministro $^{a}$} & \multicolumn{3}{|c|}{ Ministro-substituto $^{a}$} \\
\hline & $\begin{array}{c}\text { Amostra } \\
1\end{array}$ & $\begin{array}{c}\text { Amostra } \\
2\end{array}$ & $\begin{array}{c}\text { Amostra } \\
\text { total }\end{array}$ & $\begin{array}{c}\text { Amostra } \\
1\end{array}$ & $\begin{array}{c}\text { Amostra } \\
2\end{array}$ & $\begin{array}{l}\text { Amostra } \\
\text { total }\end{array}$ \\
\hline A & $\begin{array}{c}27 \\
(11,2)\end{array}$ & $\begin{array}{c}26 \\
(11,1)\end{array}$ & $\begin{array}{c}53 \\
(11,1)\end{array}$ & $\begin{array}{c}17 \\
(13,1)\end{array}$ & $\begin{array}{c}16 \\
(11,8)\end{array}$ & $\begin{array}{c}33 \\
(12,4)\end{array}$ \\
\hline B & $\begin{array}{c}40 \\
(16,6)\end{array}$ & $\begin{array}{c}52 \\
(22,1)\end{array}$ & $\begin{array}{c}92 \\
(19,3)\end{array}$ & $\begin{array}{c}18 \\
(13,8)\end{array}$ & $\begin{array}{c}22 \\
16,2)\end{array}$ & $\begin{array}{c}40 \\
(15)\end{array}$ \\
\hline $\mathrm{C}$ & $\begin{array}{c}66 \\
(27,4)\end{array}$ & $\begin{array}{c}57 \\
(24,3)\end{array}$ & $\begin{array}{c}123 \\
(25,8)\end{array}$ & $\begin{array}{c}40 \\
(30,8)\end{array}$ & $\begin{array}{c}37 \\
(27,2)\end{array}$ & $\begin{array}{c}77 \\
(28,9)\end{array}$ \\
\hline $\mathrm{D}$ & $\begin{array}{c}37 \\
(15,4)\end{array}$ & $\begin{array}{c}29 \\
(12,3)\end{array}$ & $\begin{array}{c}66 \\
(13,9)\end{array}$ & $\begin{array}{c}12 \\
(9,2)\end{array}$ & $\begin{array}{c}7 \\
(5,1)\end{array}$ & $\begin{array}{c}19 \\
(7,1)\end{array}$ \\
\hline Mais de um ato & $\begin{array}{c}64 \\
(26,6)\end{array}$ & $\begin{array}{c}70 \\
(29,8)\end{array}$ & $\begin{array}{c}134 \\
(28,2)\end{array}$ & $\begin{array}{c}42 \\
(32,3)\end{array}$ & $\begin{array}{c}49 \\
(36)\end{array}$ & $\begin{array}{c}91 \\
(34,2)\end{array}$ \\
\hline Sigiloso & $\begin{array}{c}7 \\
(2,9)\end{array}$ & $\begin{array}{c}1 \\
(0,4)\end{array}$ & $\begin{array}{c}8 \\
(1,7)\end{array}$ & $\begin{array}{c}1 \\
(0,8)\end{array}$ & $\begin{array}{c}5 \\
(3,7)\end{array}$ & $\begin{array}{c}6 \\
(2,3)\end{array}$ \\
\hline Total & $\begin{array}{c}241 \\
(100)\end{array}$ & $\begin{array}{c}235 \\
(100)\end{array}$ & $\begin{array}{c}476 \\
(100)\end{array}$ & $\begin{array}{c}130 \\
(100)\end{array}$ & $\begin{array}{c}136 \\
(100)\end{array}$ & $\begin{array}{c}266 \\
(100)\end{array}$ \\
\hline
\end{tabular}

Nota. $N=$ Amostra 1: 371; Amostra 2: 371; Amostra total: 742

A Tabela 26 descreve o tempo de duração dos processos de TCE em que Ministros e Ministros-substitutos foram os relatores responsáveis. Apesar de diferenças quanto a duração máxima dos processos, com valores maiores para Ministros (um caso com 18 e dois com 16 anos), as médias foram bem próximas em todas as amostras para os dois cargos. 
Tabela 26

Médias, desvio padrão e distribuição das medidas referentes a duração dos processos de TCE em anos em função do cargo do relator em todas as amostras

\begin{tabular}{lccccccc}
\hline Cargo & Amostra $^{a}$ & $\mathrm{~N}$ & Amplitude & Mínimo & Máximo & $M$ & $D P$ \\
\hline \multirow{2}{*}{ Ministro } & 1 & 241 & 18,29 & 0,26 & 18,55 & 4,11 & 3,05 \\
& 2 & 235 & 15,91 & 0,50 & 16,41 & 3,96 & 3,03 \\
& Total & 476 & 18,29 & 0,26 & 18,55 & 4,04 & 3,04 \\
\multirow{2}{*}{ Ministro- } & 1 & 130 & 12,50 & 0,71 & 13,21 & 4,01 & 2,80 \\
substituto & 2 & 136 & 13,45 & 0,66 & 14,11 & 4,37 & 2,90 \\
& Total & 266 & 13,45 & 0,66 & 14,11 & 4,18 & 2,85 \\
\hline
\end{tabular}

Nota. ${ }^{a} N$ (processos analisados) $=$ Amostra 1: 371; Amostra 2: 371; Amostra total: 742.

As Tabela 27 e 28 apresentam, respectivamente, os resultados descritivos pra o número de acórdãos (acórdãos total) e de processos apensados em processos de TCE por Ministro ou Ministro-substituto. Apesar do número de processos ser maior para Ministros, as distribuições das medidas e valores das médias desmontaram tendências similares para os dois cargos em todas as amostras.

Tabela 27

Médias, desvio padrão e distribuição das medidas referentes ao número de acórdãos emitidos nos processos de TCE em função do cargo do relator em todas as amostras

\begin{tabular}{lccccccc}
\hline \multirow{2}{*}{ Cargo } & Amostra $^{a}$ & $\mathrm{~N}$ & Amplitude & Mínimo & Máximo & $M$ & $D P$ \\
\hline \multirow{3}{*}{ Ministro } & 1 & 240 & 6 & 1 & 7 & 1,95 & 1,16 \\
& 2 & 235 & 9 & 0 & 9 & 1,90 & 1,26 \\
& Total & 475 & 9 & 0 & 9 & 1,93 & 1,21 \\
\multirow{2}{*}{ Ministro- } & 1 & 130 & 6 & 1 & 7 & 1,74 & 1,08 \\
substituto & 2 & 136 & 5 & 0 & 5 & 1,82 & 1,17 \\
& Total & 266 & 7 & 0 & 7 & 1,78 & 1,13 \\
\hline
\end{tabular}

Nota. ${ }^{a} N($ processos analisados $)=$ Amostra 1: 371; Amostra 2: 371; Amostra total: 742. 
Tabela 28

Médias, desvio padrão e distribuição das medidas referentes ao número de processos apensados aos processos de TCE em função do cargo do relator em todas as amostras

\begin{tabular}{lccccccc}
\hline \multirow{2}{*}{ Cargo } & Amostra $^{a}$ & $\mathrm{~N}$ & Amplitude & Mínimo & Máximo & $M$ & $D P$ \\
\hline \multirow{3}{*}{ Ministro } & 1 & 241 & 29 & 0 & 29 & 3,85 & 4,87 \\
& 2 & 235 & 33 & 0 & 33 & 3,96 & 4,85 \\
& Total & 476 & 33 & 0 & 33 & 3,90 & 4,85 \\
Ministro- & 1 & 130 & 30 & 0 & 30 & 3,52 & 3,72 \\
substituto & 2 & 136 & 30 & 0 & 30 & 4,02 & 4,81 \\
& Total & 266 & 30 & 0 & 30 & 3,78 & 4,31 \\
\hline
\end{tabular}

Nota. ${ }^{a} N$ (processos analisados) $=$ Amostra 1: 371; Amostra 2: 371; Amostra total: 742.

Tipo de sanção. Nesta seção estão descritos os resultados das análises descritivas relativas a variáveis relacionadas ao tipo de sanção proposta pelos relatores em processos de TCE. As análises se referem a três tipos de sanção previstas pela Lei Orgânica do TCU (2002): as multas baseadas nos art. 57, 58, e a pena de inabilitação.

Nas Tabelas 29 e 30 estão dispostos respectivamente os resultados para o valor da multa prevista pelo art. 57 (multa 57) e para a porcentagem da multa prevista 57 (\% multa 57) em processos de TCE relatados por Ministro ou Ministro-substituto. Os valores médios para as duas variáveis foram consistentes entre amostras e maiores para Ministros. 
Tabela 29

Médias, desvio padrão e distribuição das medidas referentes a multa baseada no art. 57 (multa 57) aplicada em processos de TCE em função do cargo do relator em todas as amostras

\begin{tabular}{lccccccc}
\hline Colegiado & Amostra $^{a}$ & $\mathrm{~N}$ & Amplitude & Mínimo & Máximo & $M$ & $D P$ \\
\hline \multirow{2}{*}{ Ministro } & 1 & 188 & 298000 & 2000 & 300000 & 22336,93 & 40455,20 \\
& 2 & 164 & 248500 & 1500 & 250000 & 21209,15 & 34067,38 \\
& Total & 352 & 298500 & 1500 & 300000 & 21811,48 & 37566,11 \\
Ministro- & 1 & 102 & 124500 & 500 & 125000 & 14406,87 & 20520,66 \\
substituto & 2 & 105 & 198500 & 1500 & 200000 & 16023,81 & 24596,29 \\
& Total & 207 & 199500 & 500 & 200000 & 15227,05 & 22639,41 \\
\hline
\end{tabular}

Nota. ${ }^{a} N($ processos analisados $)=$ Amostra 1: 371; Amostra 2: 371; Amostra total: 742.

Tabela 30

Médias, desvio padrão e distribuição das medidas referentes a porcentagem da multa baseada no art. 57 (\% multa 57) aplicada em processos de TCE em função do cargo do relator em todas as amostras

\begin{tabular}{lccccccc}
\hline Cargo & Amostra $^{a}$ & $\mathrm{~N}$ & Amplitude & Mínimo & Máximo & $M$ & $D P$ \\
\hline \multirow{2}{*}{ Ministro } & 1 & 184 & 100 & 0 & 100 & 18,26 & 18,01 \\
& 2 & 162 & 83,89 & 0,11 & 84 & 17,69 & 14,75 \\
& Total & 346 & 100 & 0 & 100 & 17,99 & 16,54 \\
\multirow{2}{*}{ Ministro- } & 1 & 101 & 87,85 & 0,31 & 88,16 & 14,04 & 13,19 \\
substituto & 2 & 105 & 63,62 & 0,38 & 64 & 13,19 & 10,61 \\
& Total & 206 & 87,85 & 0,31 & 88,16 & 13,61 & 11,93 \\
\hline
\end{tabular}

Nota. ${ }^{a} N($ processos analisados $)=$ Amostra 1: 371; Amostra 2: 371; Amostra total: 742.

No que se refere ao valor total (multa 58) e porcentagem do valor da multa prevista pelo art. 58 (\% multa 58), os resultados estão descritos respectivamente nas Tabelas 31 e 32 . Foi 
possível verificar que os valores médios e máximos das duas variáveis foram maiores para

Ministros e consistentes entre as amostras.

Tabela 31

Médias, desvio padrão e distribuição das medidas referentes a multa baseada no art. 58 (multa 58) aplicada em processos de TCE em função do cargo do relator em todas as amostras

\begin{tabular}{lccccccc}
\hline Colegiado & Amostra $^{a}$ & $\mathrm{~N}$ & Amplitude & Mínimo & Máximo & $M$ & $D P$ \\
\hline \multirow{2}{*}{ Ministro } & 1 & 34 & 28350 & 1650 & 30000 & 5519,12 & 5079,85 \\
& 2 & 48 & 29000 & 1000 & 30000 & 5509,21 & 5096,89 \\
& Total & 82 & 29000 & 1000 & 30000 & 5513,32 & 5058,35 \\
Ministro- & 1 & 22 & 8000 & 2000 & 10000 & 3977,27 & 2026,47 \\
substituto & 2 & 22 & 13250 & 1750 & 15000 & 4534,09 & 3257,14 \\
& Total & 44 & 13250 & 1750 & 15000 & 4255,68 & 2695,54 \\
\hline
\end{tabular}

Nota. ${ }^{a} N($ processos analisados $)=$ Amostra 1: 371; Amostra 2: 371; Amostra total: 742.

Tabela 32

Médias, desvio padrão e distribuição das medidas referentes a porcentagem da multa baseada no art. 58 aplicada em processos de TCE em função do cargo do relator em todas as amostras

\begin{tabular}{lccccccc}
\hline \multirow{2}{*}{ Cargo } & Amostra $^{a}$ & $\mathrm{~N}$ & Amplitude & Mínimo & Máximo & $M$ & $D P$ \\
\hline \multirow{3}{*}{ Ministro } & 1 & 33 & 90 & 5 & 95 & 15,79 & 16,05 \\
& 2 & 48 & 88 & 3 & 91 & 14,58 & 14,86 \\
& Total & 81 & 92 & 3 & 95 & 15,07 & 15,27 \\
\multirow{3}{*}{ Ministro- } & 1 & 22 & 21 & 5 & 26 & 10,23 & 5,20 \\
substituto & 2 & 22 & 32 & 4 & 36 & 11,54 & 8,16 \\
& Total & 44 & 32 & 4 & 36 & 10,89 & 6,80 \\
\hline
\end{tabular}

Nota. ${ }^{a} N($ processos analisados $)=$ Amostra 1: 371; Amostra 2: 371; Amostra total: 742. 
Os resultados quanto a sua frequência estão na tabela dispostos da sanção de inabilitação estão disposto na Tabela 33. As comparações entre amostras não foram consistentes, pois a sanção foi mais frequente para Ministros na primeira amostra e para Ministros-substitutos na segunda. Porém, considerando a amostra completa, essa sanção foi relativamente mais frequente nos casos em que Ministros foram relatores.

Tabela 33

Frequência (e porcentagem) de ocorrência de sanção de inabilitação nos processos de TCE em função do cargo do relator em todas as amostras

\begin{tabular}{lcccccccc}
\hline & \multicolumn{3}{c}{ Ministro } & & \multicolumn{3}{c}{ Ministro-substituto } \\
\cline { 2 - 4 } \cline { 7 - 9 } Inabilitação & Amostra & Amostra & Amostra & & Amostra & Amostra & Amostra \\
total & & & 1 & 2 & total \\
\hline \multirow{2}{*}{ Sim } & 20 & 10 & 30 & & 5 & 14 & 19 \\
& $(8,3)$ & $(4,3)$ & $(6,3)$ & & $(3,8)$ & $(10,3)$ & $(7,1)$ \\
Não & 221 & 225 & 446 & & 125 & 122 & 247 \\
& $(91,7)$ & $(95,7)$ & $(93,7)$ & & $(96,2)$ & $(89,7)$ & $(92,9)$ \\
\hline \multirow{2}{*}{ Total } & 241 & 235 & 446 & & 130 & 136 & 266 \\
& $(100)$ & $(100)$ & $(100)$ & & $(100)$ & $(100)$ & $(100)$ \\
\hline
\end{tabular}

Nota. $N=$ Amostra 1: 371; Amostra 2: 371; Amostra total: 742.

Análises inferenciais. No que se refere à identificação de diferenças significantes e de preditores relacionados às características das variáveis dos processos de TCE em função do cargo ocupado pelo relator (Ministro vs. Ministro-substituto), foram conduzidas as mesmas análises realizadas para as comparações entre colegiados (ANOVA, regressão linear múltipla). Tais análises adotaram critérios semelhantes aos estabelecidos anteriormente, no entanto, por estabelecer contrastes ou predições em apenas dois grupos (cargo do relator) ao invés de três (colegiados), algumas análises foram adaptadas a tal característica.

Análises de variância. As análises que compararam as medidas das variáveis relativas aos processos de TCE em função do cargo do relator (ANOVA unidirecional) indicaram 
diferenças significantes entre grupos apenas para a variável \% multa 57, e isso o que se verificou em todas as amostras: $1^{\mathrm{a}}$ amostra, $F(1,263)=4,26=p<0,04 ; 2^{\mathrm{a}} \operatorname{amostra}, F(1,265)=7,31=p<$ 0,01; amostra completa, $F(1,550)=11,03=p<0,01$. No que se refere as demais medidas, os resultados não foram verificadas diferenças consistentes em termos de significância estatística em pelo menos duas das três amostras, e desse modo, esses não foram apresentados.

Portanto, levando em consideração os dados obtidos, é possível afirmar que não existem diferenças quantitativas consideráveis entre as características dos processos conduzidos pelos relatores em função de seu cargo (Ministro ou Ministro-substituto). A única regularidade identificada foi em relação a \% multa 57. Ainda assim, os valores verificados para $F$ foram relativamente baixos, ressaltando que tais diferenças não possuem grande magnitude.

Assim como no estudo anterior, também foram realizadas análises não-paramétricas (Kruskall-Wallis) para comparar as médias obtidas para cada medida. Assim como foram verificados no estudo anterior, os dados foram praticamente idênticos quanto a identificação de diferenças significantes entre grupos. A única diferença em termos da identificação de diferenças significantes pela análise Kruskal-Wallis, foi referente a variável multa 57, em que foram verificados coeficientes significantes $(p<0,05)$ na amostra 1 e amostra total.

Por fim, adotando como critério de inclusão apenas as variáveis que apresentaram diferenças significantes na análise conduzida anteriormente para colegiados (ver Tabela 15, Estudo 2), foram calculadas e comparadas as médias dessas variáveis (análise descritiva). Os cálculos e comparações das médias empregaram a amostra total e foram realizados para nove variáveis. Os resultados indicaram que seis medidas apresentaram valores maiores para os processos em que Ministros foram relatores e três para aqueles dos Ministros-substitutos. Desse modo, ressaltou-se que tais diferenças não puderam ser consideradas sistemáticas, enfatizando 
que as diferenças nas características dos processos de TCE nos quais Ministros ou Ministrossubstitutos foram relatores não parecem ser são quantitativamente relevantes.

Regressões múltiplas. Atendendo os mesmo critério empregados para o nível de análise de colegiado, três tipos de modelos de regressão foram calculados para todas as amostras. A única diferença das análises anterior se refere a variável categórica relacionada a colegiado, que nas presentes análises foram substituídas pelo cargo do relator. Desse modo, todas as regressões conduzidas para o nível de análise cargo do relator estão descritas na Figura 4.

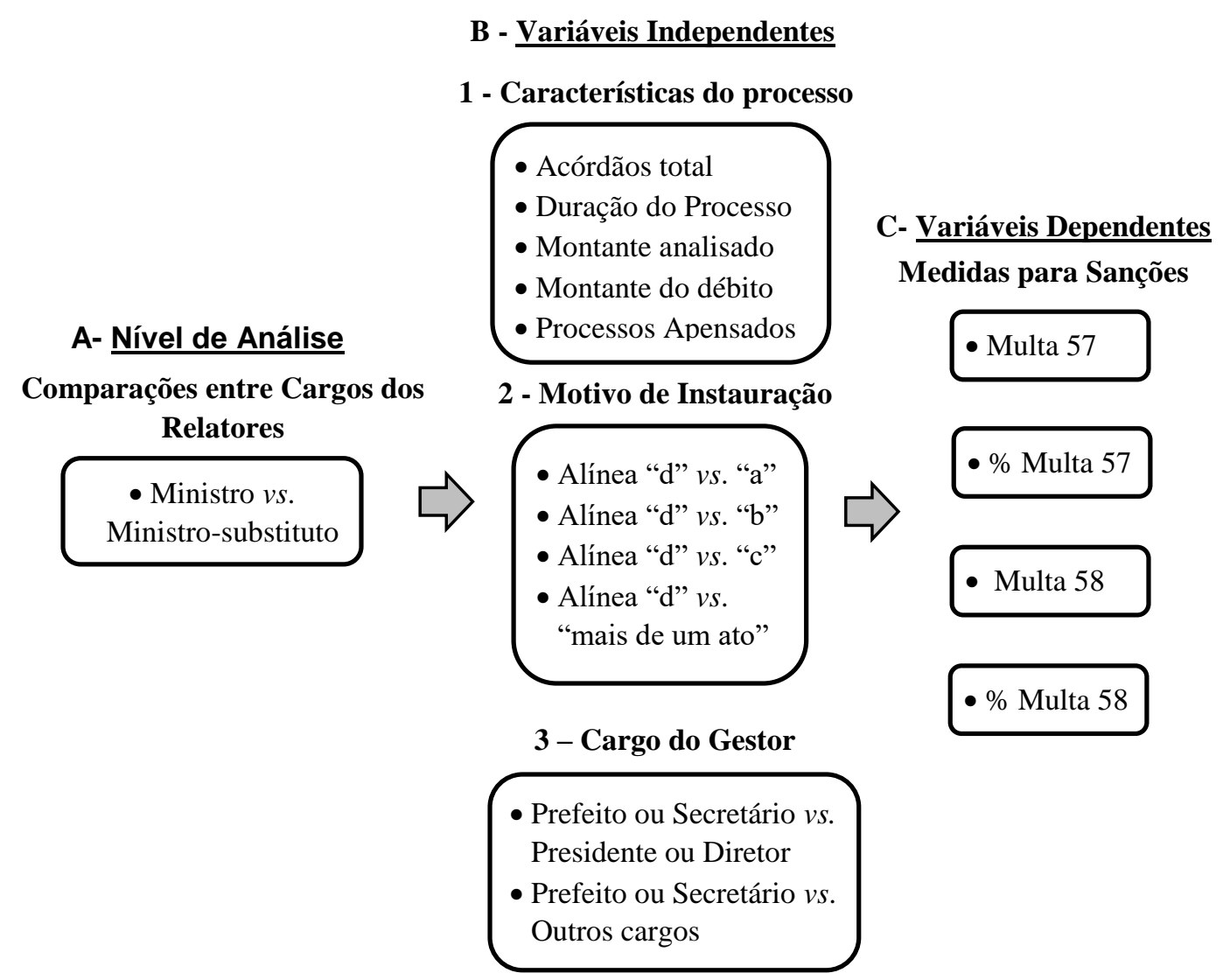

Figura 4. Esquema representativo dos três tipos de regressões múltiplas conduzidas para o nível de análise cargo do relator. Em todas as regressões foram empregados a variável A e um dos grupos de variáveis B como preditores (1, 2 ou 3) para cada uma das quatros variáveis dependentes $(\mathrm{C})$. 
Regressões para a variável multa 57. A Tabela 34 contém os parâmetros obtidos pelas regressões múltiplas para a variável multa 57 com o primeiro grupo de variáveis independentes (características do processo) para as três amostras. Os resultados para os modelos de regressão foram os seguintes: $1^{\text {a }}$ amostra, $R^{2}=0,17, F(6,277)=9,49=p<0,01 ; 2^{\text {a }}$ amostra, $R^{2}=0,11, F$ $(6,231)=4,94=p<0,01 ;$ amostra completa, $R^{2}=0,11, F(6,515)=10,91=p<0,01$.

No que se refere aos coeficientes obtidos pelas regressões (Tabela 34), só foram verificados valores significantes e consistentes (pelos menos em duas amostras) para, montante do débito e quanto ao tipo de cargo do relator do processo (cargo do relator). Assim como se verificou no nível de análise anterior, a variável montante do débito se apresentou como o preditor mais consistente sendo significante $(p<0,01)$ e com coeficientes positivos em todas as amostras. No entanto, no que se refere ao cargo ocupado pelo relator, as regressões só apresentaram coeficientes significantes em duas das três amostras.

Tabela 34

Parâmetros aferidos por regressão múltipla com os preditores relacionados a características do processo para a variável multa 57 em todas as amostras para o nível de análise cargo do relator

\begin{tabular}{lcccc}
\hline Variável & Amostra $^{a}$ & $\mathrm{~B}$ & Erro Padrão (B) & $\beta^{b}$ \\
\hline \multirow{3}{*}{ Montante débito } & 1 & 0 & 0 & $0,454 * * *$ \\
& 2 & 0 & 0 & $0,331^{* * *}$ \\
& Total & 0 & 0 & $0,314 * * *$ \\
Ministro vs. Ministro-substituto & 1 & 0,419 & 0,126 & $0,185^{* * *}$ \\
& 2 & 0,203 & 0,143 & 0,089 \\
& Total & 0,308 & 0,095 & $0,136^{* * *}$ \\
\hline
\end{tabular}

Nota. ${ }^{a} N$ (processos analisados) $=$ Amostra 1: 371; Amostra 2: 371; Amostra total: 742 .

$b * * * p<0,01 ; * * p<0,05 ; * p<0,10$.

Os parâmetros das regressões obtidos para o segundo grupo de preditores estão descritos na Tabela 35. Os resultados para os modelos calculados nas três amostras foram os seguintes: $1^{\mathrm{a}}$ 
amostra, $R^{2}=0,28, F(6,280)=18,15=p<0,01 ; 2^{\mathrm{a}}$ amostra, $R^{2}=0,15, F(6,261)=7,56=p<$ 0,01; amostra completa, $R^{2}=0,18, F(6,548)=20,39=p<0,01$. Como indicam os resultados na Tabela 35, novamente foi verificada uma relação direta entre variável motivo de instauração e a variável multa 57. Todas as comparações das outras categorias de atos infracionais com a alínea “d” obtiveram coeficientes negativos, e com exceção de um caso, todos foram significantes. Já no que concerne cargo relator enquanto preditor para os valores da multa, verificaram-se tendências relativamente menos consistentes, com coeficientes significantes em duas amostras.

Tabela 35

Parâmetros aferidos por regressão múltipla com os preditores relacionados ao motivo de instauração para a variável multa 57 em todas as amostras para o nível de análise cargo do relator

\begin{tabular}{|c|c|c|c|c|}
\hline Variável & Amostra $^{a}$ & $\mathrm{~B}$ & Erro Padrão (B) & $\beta^{b}$ \\
\hline \multirow{3}{*}{ Montante débito } & 1 & 0 & 0 & $0,385 * * *$ \\
\hline & 2 & 0 & 0 & $0,278 * * *$ \\
\hline & Total & 0 & 0 & $0,289 * * *$ \\
\hline \multirow{3}{*}{ Ministro vs. Ministro-substituto } & 1 & 0,325 & 0,115 & $0,144 * * *$ \\
\hline & 2 & 0,154 & 0,127 & 0,070 \\
\hline & Total & 0,229 & 0,087 & $0,103 * * *$ \\
\hline \multirow{3}{*}{ Alínea "a" vs. "d" } & 1 & $-1,206$ & 0,204 & $-0,383 * * *$ \\
\hline & 2 & $-0,732$ & 0,244 & $-0,239 * * *$ \\
\hline & Total & $-0,962$ & 0,159 & $-0,310 * * *$ \\
\hline \multirow{3}{*}{ Alínea "b" vs. "d" } & 1 & $-1,193$ & 0,259 & $-0,268 * * *$ \\
\hline & 2 & $-0,820$ & 0,303 & $-0,187 * * *$ \\
\hline & Total & $-1,019$ & 0,200 & $-0,231 * * *$ \\
\hline \multirow{3}{*}{ Alínea "c" vs. "d" } & 1 & $-0,793$ & 0,169 & $-0,345^{* * *}$ \\
\hline & 2 & $-0,463$ & 0,212 & $-0,199 * *$ \\
\hline & Total & $-0,625$ & 0,135 & $-0,271 * * *$ \\
\hline \multirow{3}{*}{ "Mais de um ato" vs. Alínea "d" } & 1 & $-0,634$ & 0,170 & $-0,273 * * *$ \\
\hline & 2 & $-0,214$ & 0,209 & $-0,097$ \\
\hline & Total & $-0,427$ & 0,134 & $-0,188 * * *$ \\
\hline
\end{tabular}

Nota. ${ }^{a} N$ (processos analisados) $=$ Amostra 1: 371; Amostra 2: 371; Amostra total: 742 .

$b * * * p<0,01 ; * * p<0,05 ; * p<0,10$. 
Como é possível verificar na Tabela 36, os coeficientes relacionados as variáveis colegiado e montante do débito significantes $(p<0,01)$ e positivos nas três amostras. Já no que se refere as comparações de casos envolvendo o cargo de prefeito em relação a outros cargos (e.g., tesoureiro, bolsista, funcionário público) aos coeficientes obtidos foram positivos e significantes em duas amostras $(p<0,01)$. Tais resultados indicam que os casos envolvendo outros cargos apresentaram valores de multa superiores em relação aos casos nos quais prefeitos foram os responsáveis pela irregularidade, sobretudo quando os ministros são relatores do processo.

Tabela 36

Parâmetros aferidos por regressão múltipla com os preditores relacionados a cargo do gestor para a variável multa 57 em todas as amostras para o nível de análise cargo do colegiado

\begin{tabular}{lcccc}
\hline Variável & Amostra $^{a}$ & B & Erro Padrão (B) & $\beta^{b}$ \\
\hline \multirow{2}{*}{ Montante do débito } & 1 & 0 & 0 & $0,369^{* * *}$ \\
& 2 & 0 & 0 & $0,296^{* * *}$ \\
& Total & 0 & 0 & $0,303^{* * *}$ \\
Ministro vs. Ministro-substituto & 1 & 0,397 & 0,130 & $0,172^{* * *}$ \\
& 2 & 0,197 & 0,137 & 0,091 \\
Outros cargos $v s$. Prefeito & Total & 0,302 & 0,095 & $0,135^{* * *}$ \\
& 1 & 0,657 & 0,162 & $0,233^{* * *}$ \\
& 2 & 0,198 & 0,177 & 0,074 \\
\hline
\end{tabular}

Nota. ${ }^{a} N$ (processos analisados) $=$ Amostra 1: 371; Amostra 2: 371; Amostra total: 742.

$b * * * p<0,01 ; * * p<0,05 ; * p<0,10$

Regressões para a variável \% multa 57. Os resultados para o primeiro grupo de preditores características do processo (ver Figura 4) em relação a variável dependente \% multa 57 foram os seguintes: $1^{\mathrm{a}}$ amostra, $R^{2}=0,17, F(6,277)=9,78=p<0,01 ; 2^{\mathrm{a}}$ amostra, $R^{2}=0,22$, $F(6,231)=10,86=p<0,001 ;$ amostra completa, $R^{2}=0,16, F(6,541)=16,76=p<0,00$. 
Os parâmetros obtidos a partir das análises de regressão múltipla com o primeiro grupo de variáveis estão descritos na Tabela 37. Novamente os dados demonstram que o preditor mais consistente para a porcentagem da multa do art. 57 é a variável montante do débito, com coeficientes significantes $(p<0,01)$ nas três amostras. As variáveis montante do débito e acórdãos total apresentaram coeficientes negativos, indicando que processos com maiores débitos e números de acórdãos tendem a ter valores percentuais menores de multa. Também se verificou coeficientes significantes em duas amostras para as comparações entre o cargo de Ministro e Ministro-substituto (cargo do relator). Como tais coeficientes foram positivos, os resultados indicam que porcentagem de multa para os casos em que os Ministros são relatores tende a ser maior que as dos Ministros-substituto.

Tabela 37

Parâmetros aferidos por regressão múltipla com os preditores relacionados a características do processo para a variável \% multa 57 em todas as amostras para o nível de análise cargo do relator

\begin{tabular}{lcccc}
\hline Variável & Amostra $^{a}$ & $\mathrm{~B}$ & Erro Padrão & $\beta^{b}$ \\
\hline \multirow{2}{*}{ Montante débito } & 1 & 0 & 0 & $-0,489^{* * *}$ \\
& 2 & 0 & 0 & $-0,366^{* * *}$ \\
& Total & 0 & 0 & $-0,333^{* * *}$ \\
Ministro vs. Ministro-substituto & 1 & 0,232 & 0,120 & $0,108^{*}$ \\
& 2 & 0,243 & 0,113 & $0,126^{* *}$ \\
& Total & 0,264 & 0,083 & $0,129 * * *$ \\
Acórdãos total & 1 & $-0,139$ & 0,064 & $-0,137 * *$ \\
& 2 & $-0,075$ & 0,058 & $-0,090$ \\
& Total & $-0,127$ & 0,044 & $-0,137 * * *$ \\
\hline
\end{tabular}

Nota. ${ }^{a} N$ (processos analisados) $=$ Amostra 1: 371; Amostra 2: 371; Amostra total: 742.

$b * * * p<0,01 ; * * p<0,05 ; * p<0,10$

Os resultados para os modelos de regressão empregando o segundo grupo de variáveis (motivo de instauração, ver Figura 4), foram os seguintes: $1^{\mathrm{a}}$ amostra, $R^{2}=0,21, F(6,280)=$ 
$12637=p<0,01 ; 2^{\mathrm{a}}$ amostra, $R^{2}=0,20, F(6,261)=11,16=p<0,01 ;$ amostra completa, $R^{2}=$ $0,19, F(6,548)=21,06=p<0,00$.

Conforme indicam os resultados dispostos na Tabela 38, os coeficientes dos preditores relacionados ao cargo do relator, motivo se instauração e montante do débito foram significantes e consistentes na maior parte dos casos (14 de 18). Com exceção dos coeficientes obtidos para as comparações do cargo do relator (Ministros vs. Ministros substitutos), todos os coeficientes foram negativos. Ou seja, processos com débitos menores, relacionados a infrações descritas pela alínea "d", tendem a ser multas com valores percentuais maiores, sobretudo se forem emitidas por Ministros.

No que se refere ao terceiro tipo de regressão (ver Figura 4), que analisou o a variável cargo do gestor em relação a variável \% multa 57, apesar dos modelos terem apresentado significância nas três amostras $(p<0,01)$, nenhum dos preditores relacionados ao cargo do gestor que cometeu a infração apresentou coeficientes significantes e consistentes, mesmo considerando um $p<0,10$. Como o principal intuito desse modelo de regressão era investigar possíveis relações entre a porcentagem da multa do art. 57 e o cargo ocupado pelo gestor, e tal regularidade não foi verificada, tais análises não foram apresentadas.

Regressões para a variável multa 58 e para \% multa 58. Conforme verificados anteriormente, as análises variância (ANOVA) e Kruskal-Wallis não revelaram resultados consistentes para as variáveis dependentes multa 58 e \% multa 58. Ainda assim, como também foi realizado anteriormente, os mesmos tipos de regressões múltiplas foram conduzidas atendendo os critérios descritos acima, e os resultados indicaram que nenhum dos modelos de regressão foram significantes. Ou seja, os preditores propostos não estão diretamente 
relacionados aos valores da multa 58 e $\%$ multa 58 nos casos de TCE investigados no presente estudo.

Tabela 38

Parâmetros aferidos por regressão múltipla com os preditores relacionados ao motivo de instauração para a variável \% multa 57 em todas as amostras para o nível de análise cargo do relator

\begin{tabular}{|c|c|c|c|c|}
\hline Variável & Amostra $^{a}$ & $\mathrm{~B}$ & Erro Padrão (B) & $\beta^{b}$ \\
\hline \multirow{3}{*}{ Montante débito } & 1 & 0 & 0 & $-0,371 * * *$ \\
\hline & 2 & 0 & 0 & $-0,429 * * *$ \\
\hline & Total & 0 & 0 & $-0,389 * * *$ \\
\hline \multirow{3}{*}{ Ministro vs. Ministro-substituto } & 1 & 0,222 & 0,115 & $0,103^{*}$ \\
\hline & 2 & 0,223 & 0,112 & $0,112 * *$ \\
\hline & Total & 0,216 & 0,081 & $0,104 * * *$ \\
\hline \multirow{3}{*}{ Alínea "a" vs. "d" } & 1 & $-0,692$ & 0,203 & $-0,231 * * *$ \\
\hline & 2 & $-0,114$ & 0,215 & $-0,041$ \\
\hline & Total & $-0,461$ & 0,148 & $-0,159 * * *$ \\
\hline \multirow{3}{*}{ Alínea "b" vs. "d" } & 1 & $-1,031$ & 0,258 & $-0,243 * * *$ \\
\hline & 2 & $-0,432$ & 0,267 & $-0,108$ \\
\hline & Total & $-0,773$ & 0,186 & $-0,188 * * *$ \\
\hline \multirow{3}{*}{ Alínea "c" vs. "d" } & 1 & $-0,395$ & 0,168 & $-0,180 * *$ \\
\hline & 2 & $-0,033$ & 0,187 & $-0,016$ \\
\hline & Total & $-0,265$ & 0,125 & $-0,123^{* *}$ \\
\hline \multirow{3}{*}{ "Mais de um ato"vs. Alínea "d" } & 1 & $-0,553$ & 0,169 & $-0,250 * * *$ \\
\hline & 2 & $-0,098$ & 0,183 & $-0,049$ \\
\hline & Total & $-0,368$ & 0,124 & $-0,174 * * *$ \\
\hline
\end{tabular}

Nota. ${ }^{a} N$ (processos analisados) $=$ Amostra 1: 371; Amostra 2: 371; Amostra total: 742.

$b * * * p<0,01 ; * * p<0,05 ; * p<0,10$.

Cargo anterior do relator. As análises descritas a seguir visaram identificar diferenças em decisões dos relatores em processos de TCE em função do tipo de cargo ocupado anteriormente à nomeação como Ministro e Ministro-substituto. Como já foi descrito anteriormente, foram determinados tipos de cargo anterior: político, por ter ocupado cargos 
comissionados em empresas públicas ou outros órgãos do governo, ter sido Deputado Federal ou Senador; e técnico, por ter ocupado cargos como os de analista jurídico ou do TCU, de ter exercido função de Ministro-Substituto ou de exercer esse atualmente.

Composição dos colegiados. A Tabela 39 descreve a composição dos colegiados em função do tipo de cargo anterior do relator. É possível verificar que em todas as amostras a distribuição entre político e técnico foi bem balanceada, com valores próximos de $50 \%$.

Tabela 39

Frequência (e porcentagem) de relatores responsáveis por acórdãos de decisão em processos de TCE em função do tipo de cargo ocupado anteriormente pelo relator em todos colegiados $e$ amostras

\begin{tabular}{|c|c|c|c|c|c|c|c|c|c|}
\hline \multirow[b]{2}{*}{$\begin{array}{l}\text { Cargo } \\
\text { anterior }\end{array}$} & \multicolumn{3}{|c|}{$1^{\text {a }}$ Câmara } & \multicolumn{3}{|c|}{$2^{\mathrm{a}}$ Câmara } & \multicolumn{3}{|c|}{ Plenário } \\
\hline & $\begin{array}{c}\text { Amostra } \\
1\end{array}$ & $\begin{array}{c}\text { Amostra } \\
2\end{array}$ & $\begin{array}{c}\text { Amostra } \\
\text { total }\end{array}$ & $\begin{array}{c}\text { Amostra } \\
1\end{array}$ & $\begin{array}{c}\text { Amostra } \\
2\end{array}$ & $\begin{array}{c}\text { Amostra } \\
\text { total }\end{array}$ & $\begin{array}{c}\text { Amostra } \\
1\end{array}$ & $\begin{array}{c}\text { Amostra } \\
2\end{array}$ & $\begin{array}{c}\text { Amostra } \\
\text { total }\end{array}$ \\
\hline \multirow[b]{2}{*}{ Político } & 9 & 9 & 10 & 8 & 7 & 8 & 9 & 7 & 9 \\
\hline & $(56,3)$ & $(56,3)$ & $(55,6)$ & $(53,3)$ & (50) & $(53,3)$ & (60) & $(50)$ & $(56,3)$ \\
\hline \multirow[b]{2}{*}{ Técnico } & 7 & 7 & 8 & 7 & 7 & 7 & 6 & 7 & 7 \\
\hline & $(43,8)$ & $(43,8)$ & $(44,4)$ & $(46,7)$ & $(50)$ & $(46,7)$ & (40) & (50) & $(43,8)$ \\
\hline \multirow{2}{*}{ Total } & 16 & 16 & 18 & 15 & 14 & 15 & 15 & 14 & 16 \\
\hline & $(100)$ & (100) & (100) & (100) & $(100)$ & (100) & $(100)$ & (100) & (100) \\
\hline
\end{tabular}

Nota. $N=$ Amostra 1: 371; Amostra 2: 371; Amostra total: 742.

Distribuição dos processos de TCE. A Tabela 40 apresenta os dados sobre a distribuição de processos de TCE (medido pelos acórdãos de decisão) entre os relatores a partir de seu cargo anterior. Os resultados indicaram uma distribuição semelhante dos processos de TCE entre os cargos político e técnico em todas as amostras. 
Tabela 40

Frequência (e porcentagem) de acórdãos de decisão emitidos em processos de TCE em função do tipo de cargo ocupado anteriormente pelo relator em todos colegiados e amostras

\begin{tabular}{|c|c|c|c|c|c|c|c|c|c|}
\hline \multirow[b]{2}{*}{$\begin{array}{l}\text { Cargo } \\
\text { anterior }\end{array}$} & \multicolumn{3}{|c|}{$1^{\text {a }}$ Câmara } & \multicolumn{3}{|c|}{$2^{\mathrm{a}}$ Câmara } & \multicolumn{3}{|c|}{ Plenário } \\
\hline & $\begin{array}{c}\text { Amostra } \\
1 \\
\end{array}$ & $\begin{array}{c}\text { Amostra } \\
2 \\
\end{array}$ & $\begin{array}{c}\text { Amostra } \\
\text { total }\end{array}$ & $\begin{array}{c}\text { Amostra } \\
1\end{array}$ & $\begin{array}{c}\text { Amostra } \\
2\end{array}$ & $\begin{array}{c}\text { Amostra } \\
\text { total }\end{array}$ & $\begin{array}{c}\text { Amostra } \\
1 \\
\end{array}$ & $\begin{array}{c}\text { Amostra } \\
2\end{array}$ & $\begin{array}{c}\text { Amostra } \\
\text { total }\end{array}$ \\
\hline \multirow{2}{*}{ Político } & 85 & 67 & 152 & 52 & 77 & 129 & 44 & 30 & 74 \\
\hline & $(56,3)$ & (50) & $(53,3)$ & $(36,4)$ & $(45,6)$ & $(41,3)$ & $(57,1)$ & $(44,1)$ & (51) \\
\hline \multirow{2}{*}{ Técnico } & 66 & 67 & 133 & 91 & 92 & 183 & 33 & 38 & 71 \\
\hline & $(43,7)$ & $(50)$ & $(46,7)$ & $(63,4)$ & $(54,4)$ & $(58,7)$ & $(42,9)$ & $(55,9)$ & (49) \\
\hline \multirow{2}{*}{ Total } & 151 & 134 & 285 & 143 & 169 & 312 & 77 & 68 & 145 \\
\hline & (100) & (100) & (100) & (100) & (100) & (100) & (100) & (100) & (100) \\
\hline
\end{tabular}

Nota. $N=$ Amostra 1: 371; Amostra 2: 371; Amostra total: 742.

Variáveis relacionadas aos processos de TCE. No que se refere ao cargo do gestor ou responsável por fundos públicos que cometeu a infração que deu início ao processo de TCE, os resultados descritos Tabela 41 indicam uma distribuição semelhante para políticos e técnicos. Novamente é possível verificar que a categoria Prefeito ou Secretário foi a mais frequente para os dois tipos de cargo anterior em todas as amostras. 
Tabela 41

Frequência (e porcentagem) de processos de TCE em função do cargo de ocupado pelo gestor ou responsável por fundos públicos em função do tipo de cargo ocupado anteriormente pelo relator em todos colegiados e amostras

\begin{tabular}{|c|c|c|c|c|c|c|}
\hline \multirow[b]{2}{*}{ Cargo do responsável } & \multicolumn{3}{|c|}{ Político $^{a}$} & \multicolumn{3}{|c|}{ Técnico $^{a}$} \\
\hline & $\begin{array}{c}\text { Amostra } \\
1\end{array}$ & $\begin{array}{c}\text { Amostra } \\
2\end{array}$ & $\begin{array}{c}\text { Amostra } \\
\text { total }\end{array}$ & $\begin{array}{c}\text { Amostra } \\
1\end{array}$ & $\begin{array}{c}\text { Amostra } \\
2\end{array}$ & $\begin{array}{c}\text { Amostra } \\
\text { total }\end{array}$ \\
\hline Prefeito ou Secretário & $\begin{array}{c}84 \\
(46,4)\end{array}$ & $\begin{array}{c}77 \\
(44,3)\end{array}$ & $\begin{array}{c}161 \\
(45,4)\end{array}$ & $\begin{array}{c}101 \\
(53,2)\end{array}$ & $\begin{array}{c}92 \\
(46,7)\end{array}$ & $\begin{array}{c}193 \\
(49,9)\end{array}$ \\
\hline Presidente ou Diretor & $\begin{array}{c}30 \\
(16,6)\end{array}$ & $\begin{array}{c}41 \\
(23,6)\end{array}$ & $\begin{array}{c}71 \\
(20)\end{array}$ & $\begin{array}{c}32 \\
(16,8)\end{array}$ & $\begin{array}{c}40 \\
(20,3)\end{array}$ & $\begin{array}{c}72 \\
(18,6)\end{array}$ \\
\hline Outros cargos & $\begin{array}{c}36 \\
(19,9)\end{array}$ & $\begin{array}{c}25 \\
(14,4)\end{array}$ & $\begin{array}{c}61 \\
(17,5)\end{array}$ & $\begin{array}{c}36 \\
(18,9)\end{array}$ & $\begin{array}{c}47 \\
(23,9)\end{array}$ & $\begin{array}{c}83 \\
(21,4)\end{array}$ \\
\hline Dados faltantes $^{a}$ & $\begin{array}{c}31 \\
(17,1) \\
\end{array}$ & $\begin{array}{c}31 \\
(17,8) \\
\end{array}$ & $\begin{array}{c}62 \\
(17,5) \\
\end{array}$ & $\begin{array}{c}21 \\
(11,1) \\
\end{array}$ & $\begin{array}{c}18 \\
(9,1) \\
\end{array}$ & $\begin{array}{c}39 \\
(10,1) \\
\end{array}$ \\
\hline Total & $\begin{array}{c}181 \\
(100)\end{array}$ & $\begin{array}{c}174 \\
(100)\end{array}$ & $\begin{array}{c}355 \\
(100)\end{array}$ & $\begin{array}{c}190 \\
(100)\end{array}$ & $\begin{array}{c}197 \\
(100)\end{array}$ & $\begin{array}{c}387 \\
(100)\end{array}$ \\
\hline
\end{tabular}

Nota. $N=$ Amostra 1: 371; Amostra 2: 371; Amostra total: 742. ${ }^{a}$ Dados faltantes se referem tanto a ausência de informações disponíveis nos acórdãos de decisão quanto a casos sigilosos

No se refere a distribuição de processos a partir da região do Brasil na qual ocorreram as infrações, os resultados descritos na Tabela 42 indicam que a região com o maior número de casos foi a nordeste e a com o menor número foi a região sul, tanto para políticos quanto técnicos. Usando como referência a amostra completa, os estados com o maior número de processos de TCE para o cargo anterior político foram: São Paulo, Rio de Janeiro e Minas Gerais, com respectivamente 35, 31 e 30 casos. Já para o tipo de cargo anterior técnico, o estado com o maior número de infrações foi o Maranhão (66 casos), enquanto o estado da Bahia foi o segundo (33 casos). 
Tabela 42

Frequência (e porcentagem) de processos de TCE por região do Brasil da unidade federativa onde ocorreu a irregularidade em função do tipo de cargo ocupado anteriormente pelo relator em todas as amostras

\begin{tabular}{|c|c|c|c|c|c|c|}
\hline \multirow[b]{2}{*}{ Região do Brasil } & \multicolumn{3}{|c|}{ Político $^{a}$} & \multicolumn{3}{|c|}{ Técnico $^{a}$} \\
\hline & $\begin{array}{c}\text { Amostra } \\
1\end{array}$ & $\begin{array}{c}\text { Amostra } \\
2\end{array}$ & $\begin{array}{c}\text { Amostra } \\
\text { total }\end{array}$ & $\begin{array}{c}\text { Amostra } \\
1\end{array}$ & $\begin{array}{c}\text { Amostra } \\
2\end{array}$ & $\begin{array}{c}\text { Amostra } \\
\text { total }\end{array}$ \\
\hline Centro-Oeste & $\begin{array}{c}23 \\
(12,7)\end{array}$ & $\begin{array}{c}24 \\
(13,8)\end{array}$ & $\begin{array}{c}47 \\
(13,2)\end{array}$ & $\begin{array}{c}25 \\
(13,2)\end{array}$ & $\begin{array}{c}34 \\
(17,3)\end{array}$ & $\begin{array}{c}59 \\
(15,2)\end{array}$ \\
\hline Nordeste & $\begin{array}{c}62 \\
(34,3)\end{array}$ & $\begin{array}{c}50 \\
(28,7)\end{array}$ & $\begin{array}{c}112 \\
(31,5)\end{array}$ & $\begin{array}{c}80 \\
(42,1)\end{array}$ & $\begin{array}{c}87 \\
(44,2)\end{array}$ & $\begin{array}{c}167 \\
(43,2)\end{array}$ \\
\hline Norte & $\begin{array}{c}31 \\
(17,1)\end{array}$ & $\begin{array}{c}31 \\
(17,8)\end{array}$ & $\begin{array}{c}62 \\
(17,5)\end{array}$ & $\begin{array}{c}32 \\
(16,8)\end{array}$ & $\begin{array}{c}30 \\
(15,2)\end{array}$ & $\begin{array}{c}62 \\
(16)\end{array}$ \\
\hline Sudeste & $\begin{array}{c}49 \\
(27,1)\end{array}$ & $\begin{array}{c}57 \\
(32,8)\end{array}$ & $\begin{array}{c}106 \\
(29,9)\end{array}$ & $\begin{array}{c}35 \\
(18,4)\end{array}$ & $\begin{array}{c}29 \\
(14,7)\end{array}$ & $\begin{array}{c}64 \\
(16,5)\end{array}$ \\
\hline Sul & $\begin{array}{c}16 \\
(8,8) \\
\end{array}$ & $\begin{array}{c}12 \\
(6,9) \\
\end{array}$ & $\begin{array}{c}28 \\
(7,9) \\
\end{array}$ & $\begin{array}{c}18 \\
(9,5) \\
\end{array}$ & $\begin{array}{c}17 \\
(8,6) \\
\end{array}$ & $\begin{array}{l}35 \\
(9) \\
\end{array}$ \\
\hline Total & $\begin{array}{c}181 \\
(100)\end{array}$ & $\begin{array}{c}175 \\
(100)\end{array}$ & $\begin{array}{c}355 \\
(100)\end{array}$ & $\begin{array}{c}190 \\
(100)\end{array}$ & $\begin{array}{c}197 \\
(100)\end{array}$ & $\begin{array}{c}387 \\
(100)\end{array}$ \\
\hline
\end{tabular}

Nota. $N=$ Amostra 1: 371; Amostra 2: 371; Amostra total: 742 .

A Tabela 43 apresenta a distribuição de processos de TCE em função do tipo de cargo anterior do relator a partir do tipo de infração cometida pelo gestor ou responsável por fundos públicos. Tanto para políticos quanto técnicos, a distribuição dos motivos de instauração foram bem semelhantes em todas as amostras. A categoria mais frequente foi mais de um ato (combinação de alíneas), enquanto as menos frequentes foram: a alínea " $a$ ” (omissão no dever de prestar contas) e a alínea " $d$ " (desfalque ou desvio de dinheiros, bens ou valores públicos). 
Tabela 43

Frequência (e porcentagem) de motivos de instauração de processo de TCE em função do tipo de cargo ocupado anteriormente pelo relator em todas as amostras

\begin{tabular}{|c|c|c|c|c|c|c|}
\hline \multirow[b]{2}{*}{ Motivo de instauração - Alínea } & \multicolumn{3}{|c|}{ Político $^{a}$} & \multicolumn{3}{|c|}{ Técnico $^{a}$} \\
\hline & $\begin{array}{c}\text { Amostra } \\
1\end{array}$ & $\begin{array}{c}\text { Amostra } \\
2 \\
\end{array}$ & $\begin{array}{c}\text { Amostra } \\
\text { total }\end{array}$ & $\begin{array}{c}\text { Amostra } \\
1 \\
\end{array}$ & $\begin{array}{c}\text { Amostra } \\
2 \\
\end{array}$ & $\begin{array}{c}\text { Amostra } \\
\text { total }\end{array}$ \\
\hline A & $\begin{array}{c}20 \\
(11)\end{array}$ & $\begin{array}{c}21 \\
(12,1)\end{array}$ & $\begin{array}{c}41 \\
(11,5)\end{array}$ & $\begin{array}{c}24 \\
(12,6)\end{array}$ & $\begin{array}{c}21 \\
(10,7)\end{array}$ & $\begin{array}{c}45 \\
(11,6)\end{array}$ \\
\hline B & $\begin{array}{c}28 \\
(15,5)\end{array}$ & $\begin{array}{c}44 \\
(25,3)\end{array}$ & $\begin{array}{c}72 \\
(20,3)\end{array}$ & $\begin{array}{c}30 \\
(15,8)\end{array}$ & $\begin{array}{c}30 \\
(15,2)\end{array}$ & $\begin{array}{c}60 \\
(15,5)\end{array}$ \\
\hline $\mathrm{C}$ & $\begin{array}{c}47 \\
(26)\end{array}$ & $\begin{array}{c}41 \\
(23,6)\end{array}$ & $\begin{array}{c}88 \\
(24,8)\end{array}$ & $\begin{array}{c}59 \\
(31,1)\end{array}$ & $\begin{array}{c}53 \\
(26,9)\end{array}$ & $\begin{array}{c}112 \\
(28,9)\end{array}$ \\
\hline $\mathrm{D}$ & $\begin{array}{c}28 \\
(15,5)\end{array}$ & $\begin{array}{c}20 \\
(11,5)\end{array}$ & $\begin{array}{c}48 \\
(13,5)\end{array}$ & $\begin{array}{c}21 \\
(11,1)\end{array}$ & $\begin{array}{c}16 \\
(8,1)\end{array}$ & $\begin{array}{c}37 \\
(9,6)\end{array}$ \\
\hline Mais de um ato & $\begin{array}{c}51 \\
(28,2)\end{array}$ & $\begin{array}{c}47 \\
(27)\end{array}$ & $\begin{array}{c}98 \\
(27,6)\end{array}$ & $\begin{array}{c}55 \\
(28,9)\end{array}$ & $\begin{array}{c}72 \\
(36,5)\end{array}$ & $\begin{array}{c}127 \\
(32,8)\end{array}$ \\
\hline Sigiloso & $\begin{array}{c}7 \\
(3,9)\end{array}$ & $\begin{array}{c}1 \\
(0,6)\end{array}$ & $\begin{array}{c}8 \\
(2,3)\end{array}$ & $\begin{array}{c}1 \\
(0,5)\end{array}$ & $\begin{array}{c}5 \\
(2,5)\end{array}$ & $\begin{array}{c}6 \\
(1,6)\end{array}$ \\
\hline Total & $\begin{array}{c}181 \\
(100)\end{array}$ & $\begin{array}{c}174 \\
(100)\end{array}$ & $\begin{array}{c}355 \\
(100)\end{array}$ & $\begin{array}{c}190 \\
(100)\end{array}$ & $\begin{array}{c}197 \\
(100)\end{array}$ & $\begin{array}{c}387 \\
(100)\end{array}$ \\
\hline
\end{tabular}

Nota. $N=$ Amostra 1: 371; Amostra 2: 371; Amostra total: 742

A Tabela 44 contém os resultados a respeito da duração dos processos (em anos) dos processos de TCE distribuídos por tipo de cargo anterior do relator. Os valores máximos e amplitude da foram maiores para políticos, no entanto, os valores médios de duração dos processos foram praticamente iguais para as duas categorias.

Na Tabela 45 e 46 é possível verificar os resultados quanto ao número de acórdãos (acórdãos total) processos apensados em processos de TCE pra o tipo de cargo anterior do relator. Todas as medidas foram relativamente próximas para os dois cargos e consistentes em todas as amostras. 
Tabela 44

Médias, desvio padrão e distribuição das medidas referentes a duração dos processos de TCE em anos em função do tipo de cargo anterior do relator em todas as amostras

\begin{tabular}{lccccccc}
\hline \multirow{2}{*}{ Cargo anterior } & Amostra $^{a}$ & $\mathrm{~N}$ & Amplitude & Mínimo & Máximo & $M$ & $D P$ \\
\hline \multirow{3}{*}{ Político } & 1 & 181 & 18,29 & 0,26 & 18,55 & 3,97 & 3,016 \\
& 2 & 174 & 15,67 & 0,50 & 16,17 & 3,98 & 2,99 \\
& Total & 355 & 18,29 & 0,26 & 18,55 & 3,98 & 2,99 \\
\multirow{2}{*}{ Técnico } & 1 & 190 & 12,67 & 0,54 & 13,21 & 4,17 & 2,92 \\
& 2 & 197 & 15,75 & 0,66 & 16,41 & 4,22 & 2,99 \\
& Total & 387 & 15,87 & 0,54 & 16,41 & 4,19 & 2,95 \\
\hline
\end{tabular}

Nota. ${ }^{a} N$ (processos analisados) $=$ Amostra 1: 371; Amostra 2: 371; Amostra total: 742.

Tabela 45

Médias, desvio padrão e distribuição das medidas referentes ao número de acórdãos emitidos em processos de TCE em função do tipo de cargo anterior do relator em todas as amostras

\begin{tabular}{lccccccc}
\hline Cargo anterior & Amostra $^{a}$ & $\mathrm{~N}$ & Amplitude & Mínimo & Máximo & $M$ & $D P$ \\
\hline \multirow{3}{*}{ Político } & 1 & 181 & 6 & 1 & 7 & 1,99 & 1,19 \\
& 2 & 174 & 9 & 0 & 9 & 1,84 & 1,22 \\
& Total & 355 & 9 & 0 & 9 & 1,92 & 1,21 \\
Técnico & 1 & 189 & 6 & 1 & 7 & 1,77 & 1,07 \\
& 2 & 197 & 9 & 0 & 9 & 1,89 & 1,24 \\
& Total & 386 & 9 & 0 & 9 & 1,83 & 1,163 \\
\hline
\end{tabular}

Nota. ${ }^{a} N$ (processos analisados $)=$ Amostra 1: 371; Amostra 2: 371; Amostra total: 742. 
Tabela 46

Médias, desvio padrão e distribuição das medidas referentes ao número de processos apensados em processos de TCE em função do tipo de cargo anterior do relator em todas as amostras

\begin{tabular}{lccccccc}
\hline \multirow{2}{*}{ Cargo anterior } & Amostra $^{a}$ & $\mathrm{~N}$ & Amplitude & Mínimo & Máximo & $M$ & $D P$ \\
\hline \multirow{3}{*}{ Político } & 1 & 181 & 29 & 0 & 29 & 3,88 & 5,12 \\
& 2 & 174 & 29 & 0 & 29 & 3,87 & 4,46 \\
& Total & 355 & 29 & 0 & 29 & 3,88 & 4,79 \\
Técnico & 1 & 190 & 30 & 0 & 30 & 3,59 & 3,83 \\
& 2 & 197 & 33 & 0 & 33 & 4,08 & 5,14 \\
& Total & 387 & 33 & 0 & 33 & 3,84 & 4,55 \\
\hline
\end{tabular}

Nota. ${ }^{a} N$ (processos analisados) $=$ Amostra 1: 371; Amostra 2: 371; Amostra total: 742.

Tipo de Sanção. Nessa seção estão descritos os resultados das análises descritivas relativas a variáveis relacionadas ou tipo de sanção proposta por relatores em processos de TCE. As análises se referem a três tipos de sanção: multa baseada no art. 57 ou 58 e inabilitação.

Os resultados para as variáveis multa 57 e \% multa 57 estão descritas respectivamente nas Tabelas 47 e 48 . Verificou-se que a frequência dessa sanção foi um pouco maior para a categoria de técnicos (297 no total), enquanto que os valores da absolutos e percentuais médios foram um pouco mais elevados para políticos (cerca de $17 \%$ contra $15 \%$ dos técnicos).

As Tabela 49 e 50 contém os resultados das análises descritivas para a e porcentagem da multa 58 e \% multa 58 por tipo de cargo anterior do relator. A frequência foi a mesma em termos de frequência para os dois tipos de cargo anterior (63 casos para políticos e técnicos). No que se refere aos valores absolutos e percentuais médios dessa sanção, verificaram-se médias um pouco superiores para a categoria de cargo anterior político. 
Tabela 47

Média, frequência, desvio padrão e distribuição das medidas referentes a multa baseada no art. 57 (multa 57) aplicada em processos de TCE em função do tipo de cargo anterior do relator em todas as amostras

\begin{tabular}{lccccccc}
\hline Colegiado & Amostra $^{a}$ & $\mathrm{~N}$ & Amplitude & Mínimo & Máximo & $M$ & $D P$ \\
\hline \multirow{3}{*}{ Político } & 1 & 141 & 298000 & 2000 & 300000 & 22342,19 & 41905,44 \\
& 2 & 121 & 248500 & 1500 & 250000 & 21870,25 & 37815,52 \\
& Total & 262 & 298500 & 1500 & 300000 & 22124,24 & 39993,55 \\
\multirow{2}{*}{ Técnico } & 1 & 149 & 179500 & 500 & 180000 & 16903,30 & 26603,37 \\
& 2 & 148 & 198500 & 1500 & 200000 & 16989,86 & 23419,75 \\
& Total & 297 & 199500 & 500 & 200000 & 16946,44 & 25025,20 \\
\hline
\end{tabular}

Tabela 48

Média, frequência, desvio padrão e distribuição das medidas referentes a porcentagem da multa baseada no art. 57 (\% multa 57) aplicada em processos de TCE em função do tipo de cargo anterior do relator em todas as amostras

\begin{tabular}{|c|c|c|c|c|c|c|c|}
\hline Cargo anterior & Amostra $^{a}$ & $\mathrm{~N}$ & Amplitude & Mínimo & Máximo & $M$ & $D P$ \\
\hline \multirow{3}{*}{ Político } & 1 & 141 & 100 & 0 & 100 & 16,94 & 16,62 \\
\hline & 2 & 121 & 83,89 & 0,11 & 84 & 17,08 & 14,44 \\
\hline & Total & 262 & 100 & 0 & 100 & 17,01 & 15,62 \\
\hline \multirow{3}{*}{ Técnico } & 1 & 149 & 99,69 & 0,31 & 100 & 16,60 & 16,56 \\
\hline & 2 & 148 & 63,62 & 0,38 & 64 & 14,98 & 12,55 \\
\hline & Total & 297 & 99,69 & 0,31 & 100 & 15,79 & 14,66 \\
\hline
\end{tabular}

Nota. ${ }^{a} N$ (processos analisados) = Amostra 1: 371; Amostra 2: 371; Amostra total: 742. 
Tabela 49

Médias, frequência, desvio padrão e distribuição das medidas referentes a multa baseada no art. 58 (multa 58) aplicada em processos de TCE em função do tipo de cargo anterior do relator em todas as amostras

\begin{tabular}{lccccccc}
\hline \multirow{2}{*}{ Colegiado } & $\begin{array}{c}\text { Amostra } \\
a\end{array}$ & $\mathrm{~N}$ & Amplitude & Mínimo & Máximo & $M$ & $D P$ \\
\hline \multirow{2}{*}{ Político } & 1 & 25 & 8000 & 2000 & 10000 & 4200 & 2453,74 \\
& 2 & 38 & 28500 & 1500 & 30000 & 6077,42 & 5445,22 \\
& Total & 63 & 28500 & 1500 & 30000 & 5332,41 & 4569,74 \\
\multirow{2}{*}{ Técnico } & 1 & 31 & 28350 & 1650 & 30000 & 5488,71 & 5170,65 \\
& 2 & 32 & 14000 & 1000 & 15000 & 4164,06 & 3097,61 \\
& Total & 63 & 29000 & 1000 & 30000 & 4815,87 & 4263,78 \\
\hline
\end{tabular}

Tabela 50

Médias, frequência, desvio padrão e distribuição das medidas referentes a porcentagem da multa baseada no art. 58 (\% multa 58) aplicada em processos de TCE em função do tipo de cargo anterior do relator em todas as amostras

\begin{tabular}{lccccccc}
\hline Cargo anterior & Amostra $^{a}$ & $\mathrm{~N}$ & Amplitude & Mínimo & Máximo & $M$ & $D P$ \\
\hline \multirow{3}{*}{ Político } & 1 & 25 & 25 & 5 & 30 & 12,16 & 7,29 \\
& 2 & 38 & 87 & 4 & 91 & 15,95 & 16,07 \\
& Total & 63 & 87 & 4 & 91 & 14,44 & 13,35 \\
Técnico & 1 & 31 & 90 & 5 & 95 & 14,73 & 16,46 \\
& 2 & 32 & 33 & 3 & 36 & 10,87 & 7,84 \\
& Total & 63 & 92 & 3 & 95 & 12,74 & 12,79 \\
\hline
\end{tabular}

Nota. ${ }^{a} N($ processos analisados $)=$ Amostra 1: 371; Amostra 2: 371; Amostra total: 742. 
Na Tabela 51 estão apresentados os resultados referentes a sanção de inabilitação. É possível verificar que a frequência desse tipo de sanção é baixa, com apenas 49 casos no total. Apesar de variações entre a amostra 1 e 2, a frequência foi semelhante para políticos e técnicos. Tabela 51

Frequência (e porcentagem) de ocorrência de sanção de inabilitação nos processos de TCE em função do tipo de cargo ocupado anteriormente pelo relator em todas as amostras

\begin{tabular}{|c|c|c|c|c|c|c|}
\hline \multirow[b]{2}{*}{ Inabilitação } & \multicolumn{3}{|c|}{ Político } & \multicolumn{3}{|c|}{ Técnico } \\
\hline & $\begin{array}{c}\text { Amostra } \\
1\end{array}$ & $\begin{array}{c}\text { Amostra } \\
2\end{array}$ & $\begin{array}{c}\text { Amostra } \\
\text { total }\end{array}$ & $\begin{array}{c}\text { Amostra } \\
1\end{array}$ & $\begin{array}{c}\text { Amostra } \\
2\end{array}$ & $\begin{array}{c}\text { Amostra } \\
\text { total }\end{array}$ \\
\hline Sim & $\begin{array}{c}16 \\
(8,8)\end{array}$ & $\begin{array}{c}9 \\
(5,2)\end{array}$ & $\begin{array}{l}25 \\
(7)\end{array}$ & $\begin{array}{c}9 \\
(4,7)\end{array}$ & $\begin{array}{c}15 \\
(7,6)\end{array}$ & $\begin{array}{c}24 \\
(6,2)\end{array}$ \\
\hline Não & $\begin{array}{c}165 \\
(91,2)\end{array}$ & $\begin{array}{c}165 \\
(94,8)\end{array}$ & $\begin{array}{l}330 \\
(93)\end{array}$ & $\begin{array}{c}181 \\
(95,3)\end{array}$ & $\begin{array}{c}182 \\
(92,4)\end{array}$ & $\begin{array}{c}363 \\
(93,8)\end{array}$ \\
\hline Total & $\begin{array}{c}181 \\
(100)\end{array}$ & $\begin{array}{c}174 \\
(100)\end{array}$ & $\begin{array}{c}355 \\
(100)\end{array}$ & $\begin{array}{c}190 \\
(100)\end{array}$ & $\begin{array}{c}197 \\
(100)\end{array}$ & $\begin{array}{c}387 \\
(100)\end{array}$ \\
\hline
\end{tabular}

Nota. $N=$ Amostra 1: 371; Amostra 2: 371; Amostra total: 742.

Análises inferenciais. Com intuito de verificar diferenças significantes e de preditores relacionados às características das variáveis dos processos de TCE em função do tipo de cargo ocupado anteriormente pelo relator (político $\mathrm{x}$ técnico), foram realizadas análises de variância (ANOVA), Kruskall-Wallis e regressões lineares múltiplas. Tais análises adotaram critérios semelhantes aos estabelecidos anteriormente para comparações entre colegiados (ver Estudo 2) e que também foram empregados para investigar a influência do cargo dos relatores. Assim, como nas comparações quanto ao cargo do relator, as análises aqui descritas compararam dois grupos, que foram cargos anteriores do relator divididos em: político ou técnico.

Análises de variância. Os resultados das análises (ANOVA) indicaram que não existem diferenças estatisticamente significantes $(p<0,05)$ entre as medidas das variáveis relacionadas aos processos de TCE ao se estabelecer contrastes entre o tipo do cargo do ocupado 
anteriormente pelo relator. Ou seja, os dados indicaram que não existem diferenças quantitativas relevantes entre processos em que o relator tem o seu cargo anterior classificado como político ou técnico.

Para aumentar a confiabilidade dos resultados e melhor investigar se existem diferenças estatisticamente significantes entre as medidas das variáveis independentes e dependentes em função do cargo ocupado anteriormente pelo relator, também foram realizadas comparações entre as médias a partir de uma análise não-paramétrica (Kruskal-Wallis). Assim como foram verificados para os níveis de análise de colegiado (Estudo 2) e de cargo do relator, os resultados das análises Kurskall-Wallis praticamente replicaram aqueles aferidos via ANOVA no que concerne ao cargo anterior do relator. As únicas exceções em comparação aos resultados obtidos pela ANOVA se refere a verificação de coeficientes significantes $(p<0,05)$ para a variável multa 57 apenas na amostra 2, e para as variáveis multa 58 e \% multa 58 apenas na amostra total. Portanto, de modo geral, é possível inferir que a análise Kurskall-Wallis também sinalizou a ausência de diferenças significantes e consistentes entre amostras para as medidas adotadas nesse estudo, ajudando a corroborar essa regularidade.

Assim como foi realizado anteriormente (comparações entre cargos do relator), as médias para nove medidas relacionadas ao processo foram comparadas quanto aos seus valores empregando como referência a amostra completa. Assim como identificado pela análise de variância, a diferenças entre os valores não foram grandes e não mostraram consistência entre os dois grupos (político e técnico). Considerando as nove medidas que foram comparadas, seis delas apresentaram valores maiores para o cargo anterior de técnico e três para o cargo anterior de político. Essa comparação ajuda a salientar que o tipo de cargo ocupado anteriormente pelo relator não parece ser um fator determinante nos processos de TCE. 
Regressões múltiplas. Para verificar regularidades acerca do tipo de cargo ocupado anteriormente pelo relator (cargo anterior, dividido em político ou técnico), foram empregados os mesmos modelos de regressão utilizados anteriormente para colegiado e cargo do relator. Desse modo, todas os três tipos regressões para as quatros variáveis independentes realizadas para o nível de análise tipo do cargo anterior do relator estão representadas na Figura 5.

\section{A- Nível de Análise \\ Comparações entre Tipo de Cargo Anterior do Relator}

- Político vs. Técnico

\section{B - Variáveis Independentes}

\section{1 - Características do processo}

- Acórdãos total

- Duração do processo

- Montante analisado

- Montante do débito

- Processos Apensados

2 - Motivo de Instauração

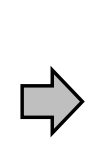

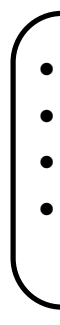

- Alínea “d” vs. "a"

- Alínea "d" vs. "b"

- Alínea “d” vs. "c"

- Alínea "d" vs.

"mais de um ato"

\section{3 - Cargo do Gestor}

- Prefeito ou Secretário vs.

Presidente ou Diretor

- Prefeito ou Secretário vs. Outros cargos

\section{C- Variáveis Dependentes}

Medidas para Sanções

- Multa 57

- \% Multa 57

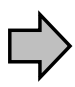

- Multa 58

- \% Multa 58

Figura 5. Esquema representativo dos três tipos de regressões múltiplas conduzidas para o nível de análise tipo de cargo anterior do relator. Em todas as regressões foram empregados a variável A e um dos grupos de variáveis B como preditores (1,2 ou 3) para cada uma das quatros variáveis dependentes $(\mathrm{C})$.

Regressões para a variável multa 57. Os resultados para o primeiro grupo de preditores em relação a variável dependente multa 57, características do processo (ver Figura 5), foram os 
seguintes: $1^{\mathrm{a}}$ amostra, $R^{2}=0,15, F(6,277)=8,25=p<0,01 ; 2^{\mathrm{a}} \operatorname{amostra}, R^{2}=0,11, F(6,231)=$ 4,62 = $p<0,01 ;$ amostra completa, $R^{2}=0,10, F(6,515)=9,63=p<0,01$.

Os parâmetros obtidos a partir das análises de regressão múltipla com o primeiro grupo de variáveis estão descritos na Tabela 52. Novamente a variável montante do débito, apresentou coeficientes significantes $(p<0,01)$ nas três amostras. Também se verificou coeficientes positivos e significantes na amostra $1(p<0,05)$ e amostra total $(p<0,10)$ para as comparações entre os tipos de cargo anterior político e técnico (cargo do relator).

Tabela 52

Parâmetros aferidos por regressão múltipla com os preditores relacionados a características do processo para a variável multa 57 em todas as amostras para o nível de análise cargo anterior do relator

\begin{tabular}{lcccc}
\hline Variável & Amostra $^{a}$ & B & Erro Padrão & Beta \\
\hline \multirow{2}{*}{ Montante débito } & 1 & 0 & 0 & $0,437 * * *$ \\
& 2 & 0 & 0 & $0,328^{* * * *}$ \\
& Total & 0 & 0 & $0,306^{* * *}$ \\
Político $v s$. Técnico & 1 & 0,262 & 0,122 & $0,122^{* *}$ \\
& 2 & 0,079 & 0,139 & 0,035 \\
& Total & 0,175 & 0,092 & $0,080^{*}$ \\
\hline
\end{tabular}

Nota. ${ }^{a} N$ (processos analisados) $=$ Amostra 1: 371; Amostra 2: 371; Amostra total: 742.

No que se refere aos resultados obtidos para os outros dois outros tipos de modelo de regressão que empregaram o grupo de variável para motivo de instauração e cargo do gestor como preditores para a variável dependente multa 57 (ver Figura 4, grupo de preditores 2 e 3), se optou por não apresentar os resultados. Apesar dos modelos terem apresentado significância nas três amostras $(p<0,01)$, nenhum dos preditores relacionados ao cargo anterior do relator (político vs. técnico) apresentou coeficientes significantes e consistentes entre as amostras, mesmo considerando um $p<0,10$. Como o principal intuito desse nível de análise era investigar 
possíveis relações entre a multa prevista pelo art. 57 e o cargo anterior ocupado pelo relator, e tal regularidade não foi verificada, tais análises não foram apresentadas.

Regressões para a variável \% multa 57. Assim como foram verificados para os níveis anteriores, os três tipos de regressão para essas duas variáveis independentes (ver Figura 5) apresentaram coeficientes significantes $(p<0,01)$ para as três amostras. Considerando os nove modelos regressões múltiplas realizados para a variável dependente \% multa 57 (3 grupos de variáveis x 3 amostras x 1 variável dependente), e assumindo um $p<0,10$, em nenhum dos casos ocorreram coeficiente significativos para o preditor relacionado ao tipo do cargo ocupado anteriormente pelo relator do processo (cargo anterior do relator). Desse modo, os resultados indicam que o tipo de cargo ocupado anteriormente pelo relator (político ou técnico) não está relacionado a alterações nos valores das variável \% multa 57. Portanto, devido à ausência de regularidades consistentes em relação a influência do tipo de cargo anterior do relator nos valores percentuais da multa predita pelo art. 57, os resultados referentes a tais regressões não foram relatados.

Regressões paras as variáveis multa 58 e \% multa 58. De modo similar aos outros níveis de análise, as regressões para as variáveis independentes relacionadas as sanções previstas pelo art. 58 (ver figura 5) não apresentaram coeficientes significantes $(p<0,10)$. Desse modo, em função da falta de regularidade entre as variáveis investigadas, tais analises foram descartadas.

Comparações entre cargo do relator e cargo anterior do relator. Em função da classificação em técnico ou político para cargo anterior do relator, atribuiu-se uma classificação de técnico para todos Ministro-substitutos. Conforme já foi apresentado anteriormente, tal classificação foi determinada em função das exigências do concurso público de comprovação de ampla conhecimento jurídico e extensa experiência nessa área. No entanto, apesar dessa 
categorização apresentar consistência lógica e se amparar no modelo desenvolvido no Estudo 1, ela acabou criando uma grande correlação entre as categorias Ministro-substituto e Técnico, e desse modo, acabou eliminando distinções mais precisas entre as variáveis cargo anterior e cargo anterior do relator.

Uma das possibilidades para resolver tal questão seria de realizar as análises para cargo anterior do relator incluindo apenas os Ministros, já que existem Ministros que se enquadram tanto na categoria técnico quanto na político. No entanto, adotar tal alternativa resultaria em uma grande redução no número de casos analisados, pois grande parte dos casos se referem a processos de TCE nos quais os relatores foram Ministros-substitutos (mais de $35 \%$ dos casos). Além disso, realizar a análise incluindo apenas os Ministros também resultaria em um desvio da consistência lógica e argumentativa das demais analises conduzidas no presente trabalho. Portanto, em função desses dois fatores, adotar tal estratégia culminaria em resultados relativamente menos representativos e que não poderiam ser diretamente comparáveis as demais análises (colegiado e cargo anterior do relator).

A partir disso, para ajudar a distinguir os efeitos dessas duas variáveis foram conduzidas novas análise de regressão linear com os três modelos que se referem a três grupos de variáveis que estão descritos nas Figuras 4 e 5 (características do processo, motivos de instauração e cargo do gestor). No entanto, nessas análises foram incluídas no modelo as variáveis independentes cargo do relator e cargo anterior do relator simultaneamente. Desse modo, foi possível verificar se de fato existe sobreposição entre essas variáveis ou se essas apresentam um efeito em conjunto sobre as variáveis que medem as sanções propostas pelos relatores dos processos.

Partindo desse critérios, os resultados para as análises complementares para as variáveis multa 57 e \% multa 57 que incluíram cargo do relator e cargo anterior do relator estão dispostas 
no Anexo I. Apesar de diferenças quanto aos valores do $R^{2}$ e dos coeficientes aferidos pelas regressões, foram identificadas tendências muito semelhantes com as análises conduzidas para cargo do relator (ver Tabelas 34, 35, 36, 37 e 38). No entanto, o resultado mais importante a se destacar é que ao serem incluídas simultaneamente no modelo, a variável cargo anterior do relator não apresentou coeficientes significantes, enquanto que foram verificados coeficientes significantes para a variável cargo do relator em praticamente todas as análises. Ou seja, apenas se verificou a influência do cargo do relator sobre os valores das medidas para a sanção baseada no art. 57 (i.e., multa 57 e \% multa 57).

Tais resultados ajudaram a esclarecer a ambiguidade entre as variáveis cargo do relator e cargo anterior do relator e evidenciaram que de fato existe sobreposição entre essas variáveis. Portanto, os resultados sugerem que há influência de cargo do relator (Ministros vs. Ministrosubstituto) e não de cargo anterior do relator (político vs. técnico) no que se refere as sanções propostas pelos relatores para os processos de TCE.

Como as análises anteriores para as variáveis relacionadas a sanção prevista pelo art. 58 (multa 58 e \% multa 58) não foram significantes para cargo do relator e nem cargo anterior do relator na análises anteriores, não foram conduzidas análises complementares para essas variáveis.

Comparações individuais entre relatores. Para melhor investigar diferenças individuais em relação a decisões de relatores em processos de TCE, um dos objetivos do presente estudo consistiu em verificar se existem diferenças entre características de processos (variáveis independentes e dependentes) entre relatores. Portanto, para alcançar tais objetivos foram realizadas comparações entre as médias (ANOVA e Kruskal-Wallis) das medidas de cada variável para cada um dos relatores que foram incluídos nas análises. Também é necessário 
salientar que para as diferenças entre os relatores individualmente, no presente estudo não foram estabelecidas distinções entre colegiado da decisão ou cargo e cargo anterior dos relatores dos processos de TCE.

Composição da amostra. Em função de fatores como como enfermidades ou aposentadoria ou designação de carga de trabalho, o número de processos que cada um dos relatores foi responsável apresentou muita variação nas amostras analisadas. A análise descritiva dos dados revelou que existem relatores com apenas 1 ou 2 casos por amostra, enquanto outros possuem mais de 40 ou 50 casos. Portanto, com intuito de realizar comparações estatisticamente válidas, foi assumido como critério de inclusão na análise que um determinado Ministro ou Ministro-substituto constasse no banco de dados em pelo menos 25 casos como relator por amostra. Com intuito de obter uma composição de amostra representativa e com resultados comparáveis as demais amostras, só foram considerados para a amostra total aqueles relatores que apresentaram pelo menos 25 casos na $1^{\mathrm{a}}$ ou $2^{\mathrm{a}}$ amostra. Desse modo, se obteve um número razoável e representativo de relatores para estabelecer comparações entre indivíduos a partir de análises estatísticas, e também foi garantido que os relatores tivessem um número de casos no qual fosse possível se identificar regularidades estáveis em cada um deles.

Assumindo o critério de inclusão de pelo menos 25 casos por amostra, a Tabela 53 contém os dados dos relatores que fizeram parte de cada uma das amostras e do número de casos pelos quais cada um foi responsável. Com intuito de preservar o sigilo de informações, os relatores foram identificados numericamente. Conforme a Tabela 53 indica, o número de relatores para as três amostras foram: $1^{\mathrm{a}}$ amostra, quatro relatores; $2^{\mathrm{a}}$ amostra cinco relatores; amostra total, 6 relatores. 
Tabela 53

Frequência (e porcentagem) de processos de TCE por amostra para cada relator que atingiu os critérios de inclusão para as análises de comparativas

\begin{tabular}{|c|c|c|c|}
\hline Identificação do relator & Amostra & Número de casos & $\%$ dos casos \\
\hline \multirow{3}{*}{1} & 1 & - & - \\
\hline & 2 & 28 & 15,2 \\
\hline & Total & 51 & 12,3 \\
\hline \multirow{3}{*}{2} & 1 & 25 & 15,5 \\
\hline & 2 & 25 & 13,6 \\
\hline & Total & 50 & 12,1 \\
\hline \multirow{3}{*}{3} & 1 & - & - \\
\hline & 2 & 38 & 20,7 \\
\hline & Total & 61 & 14,8 \\
\hline \multirow{3}{*}{4} & 1 & 56 & 34,8 \\
\hline & 2 & 55 & 29,9 \\
\hline & Total & 111 & 26,9 \\
\hline \multirow{3}{*}{6} & 1 & 42 & 26,1 \\
\hline & 2 & - & - \\
\hline & Total & 64 & 15,5 \\
\hline \multirow{3}{*}{9} & 1 & 38 & 23,6 \\
\hline & 2 & 38 & 20,7 \\
\hline & Total & 76 & 18,4 \\
\hline
\end{tabular}

Ainda de acordo com a Tabela 53, no que concerne a $1^{\mathrm{a}}$ amostra, o relator com o menor número de casos teve (relator 2) teve 25 casos enquanto que o relator 4 com 55 casos, teve o maior número. Já para a $2^{\mathrm{a}}$ amostra, o relator 1 teve o menor número de casos (28), enquanto o relator 4 teve o maior número (55). Por fim, no que se refere a amostra total (que é composta pela soma da $1^{\mathrm{a}}$ e $2^{\mathrm{a}}$ amostra), o menor número de casos de TCE foi para o relator 1 (28), enquanto o relator 4 teve 111 casos (o maior número). Tais resultados enfatizam que existem diferenças quantitativas expressivas entre o número de processos TCE nos quais Ministros e 
Ministros-substitutos atuam como relatores, mas também ressalta que tais medidas são relativamente semelhantes e consistentes entre amostras (cf. medidas amostra 1 e 2).

Análises inferenciais. A partir dos critérios de inclusão descritos acima, foram conduzidas análises de variância (ANOVA) com o intuito de identificar se existem diferenças individuais significantes entre os relatores em um nível de análise individual. Para atender os critérios da ANOVA, todos os relatores selecionados para a análise foram categorizados numericamente para serem empregados como a variável de fator, e desse modo, cada um dos relatores pode ser identificado como um grupo no contexto da análise. Portanto, na medida em que a ANOVA sinalizasse diferenças significantes entre grupos, ela estaria se referindo a diferenças entre relatores enquanto indivíduos.

É necessário enfatizar que cada amostra contou com um número diferente de relatores, que são tratados estatisticamente como grupos, portanto, para cada uma das amostras, o grau de liberdade $(g l)$ apresentou variações. Já os parâmetros obtidos pelas análises de variâncias para todas as principais medidas relacionadas aos processos de TCE para todas as amostras estão descritos na Tabela 54.

Como é possível verificar na Tabela 54, apenas a variável independente duração do processo e as variáveis dependentes inabilitação, multa 57 e \% multa 57 apresentaram diferenças significantes entre relatores $(p<0,05)$ em pelo menos duas das três amostras. Desse modo, apenas tais variáveis foram descritas na Tabela 54.

Para aumentar a confiabilidade das regularidades identificadas via ANOVA também foram conduzidas comparações entre as médias a partir de uma análise não-paramétrica (Kurskal-Wallis). Considerando o critério de ocorrerem resultados significantes em pelo menos duas amostras, os resultados para as análises não paramétricas foram novamente bastante 
semelhantes. A únicas diferenças em função desse critério se referiu as variáveis independentes montante analisado e montante do débito que apresentaram resultados significantes $(p<0,05)$ na $1^{\mathrm{a}}$ amostra e amostra total.

Tabela 54

Valores aferidos para a análise de variância unidirecional (ANOVA, teste post-hoc (Tukey's HSD) e comparação entre médias para as variáveis referentes aos processos de TCE entre os relatores

\begin{tabular}{lcccc}
\hline Variável & Amostra $^{a}$ & $g l$ & $F$ & $p$ \\
\hline Duração do processo & 1 & $(3,157)$ & 1,37 & 0,25 \\
& 2 & $(4,179)$ & 2,94 & 0,02 \\
Inabilitação & Total & $(5,407)$ & 3,04 & 0,01 \\
& 1 & $(3,157)$ & 3,51 & 0,02 \\
& 2 & $(4,179)$ & 2,95 & 0,02 \\
Multa 57 & Total & $(5,407)$ & 3,71 & 0,01 \\
& 1 & $(3,118)$ & 7,22 & 0,00 \\
\% multa 57 & 2 & $(4,132)$ & 0,81 & 0,52 \\
& Total & $(5,303)$ & 2,88 & 0,01 \\
& 1 & $(3,115)$ & 1,66 & 0,20 \\
& 2 & $(4,130)$ & 3,06 & 0,02 \\
& Total & $(5,302)$ & 2,73 & 0,02 \\
\hline
\end{tabular}

\section{Discussão}

O presente estudo investigou diferenças individuais nas características das sanções propostas por relatores de processos de TCE no TCU, e se estas podem ser atribuídas a características de histórico de aprendizagem de comportamentos jurídicos. Baseando-se no modelo teórico proposto no Estudo 1, duas variáveis foram delimitadas como representativas do histórico de aprendizagem de comportamentos jurídicos dos relatores de processos do TCU: o cargo do relator, classificado em Ministro e Ministro-substituto e o cargo anterior do relator, 
que poderia ser político e técnico. Por fim, o presente estudo também verificou se existem diferenças nas sanções em comparações entre relatores (análise entre sujeitos).

Primeiramente é necessário considerar que a partir de análises complementares se identificou que existe sobreposição entre as variáveis cargo do relator e cargo anterior do relator. Desse modo, os resultados obtidos para cargo anterior do relator devem ser considerados com cautela, até porque em muitos casos eles foram semelhantes aos resultados obtidos para cargo do relator, e, portanto, acabam apresentando redundância, principalmente no que se refere as análises inferências (i.e., análises de variância e regressões múltiplas). No entanto, assim como será demonstrado, as análises descritivas obtidas para cargo anterior do relator também apresentam dados interessantes, e conforme será discutido, permite salientar interações distintas entre as variáveis de históricos de aprendizagem, as sanções propostas por relatores e demais características dos processos de TCE.

De maneira geral, os resultados das análises de variância (corroborados por análises não paramétricas) indicaram que não existem diferenças significantes na variáveis que medem as características dos processos de TCE atribuídos a relatores, tanto em termos de cargo quanto de cargo anterior. Ou seja, o conteúdo ou matéria dos processos de TCE não apresentaram variações significantes e consistentes em função de variáveis relacionadas a histórico de aprendizagem, indicando que Ministros, Ministros substitutos ou relatores com antecedentes políticos e técnicos possuem atribuições semelhantes quanto ao tipo de processo de TCE por eles analisados.

Uma provável explicação para essa ausência de diferenças entre características dos processos de TCE em função do cargo ou cargo anterior do relator se fundamenta no próprio regimento interno do TCU. O capítulo III do regimento interno do TCU (2015) se refere 
especificamente a forma como são distribuído os processos do TCE entre Ministros e Ministrossubstitutos para que esses exerçam a função de relator.

O art. 147 especifica que os processos são distribuídos a partir de um sorteio feito de dois em dois anos pelo Presidente do TCU. De modo mais específico, o art. 148 especifica que todas as instituições e entidades que são mantidas ou recebem recursos federais são agrupados em listas de unidades jurisdicionadas (LUJ), e a partir disso, como determina o art. 150 o sorteio se refere a uma lista de unidade jurisdicionada. Desse modo, a partir desse procedimento, um determinado Ministro ou Ministro-substituto fica responsável por todos os processos relativos a lista de unidade jurisdiciona ao qual ele foi sorteado para ser o relator. O art. 150 também determina que o relator ficará responsável por essa lista por um período de dois anos, de modo que no próximo sorteio ele não poderá repetir a mesma lista (i.e., princípio da alternatividade).

Portanto, assim como descreve o regimento interno do TCU (2015) e também sugerem os resultados, não existem diferenças na atribuição de processos de TCE em função de cargo e nem de cargo anterior do relator. Portanto, quaisquer diferenças em variáveis que descrevem características de processo entre cargo ou cargo anterior dos relatores, devem ser interpretadas como um artifício do sorteio. Por exemplo, nas Tabelas 22 e 40, é possível verificar que em termos proporcionais, a carga de processos de TCE atribuídos para Ministros-substitutos e para relatores com cargo anterior técnico é relativamente maior, do que para Ministros e relatores com cargo anterior político. No entanto, como é possível notar nas tabelas 24 e 42, a maior parte dos processos de processos de TCE são oriundos da região nordeste, e justamente nessa região que existem as maiores diferenças entre ministros vs. ministros-substitutos (31,9\% vs. 47,7\% dos casos) e políticos vs. técnicos (31,5\% vs. 43,2\% dos casos) no que se refere a número de processos. Ou seja, é possível concluir que os Ministros-substitutos ou "relatores técnicos" foram 
sorteados como responsáveis por listas de unidades jurisdicionadas do nordeste com mais frequência, e por isso, acabaram com uma carga de processos de TCE relativamente maior.

A ausência de diferenças significantes em variáveis que descrevem características do processo, ou seja, a sua matéria ou o conteúdo, em função do cargo ou cargo anterior do relator parece ser algo desejável de um ponto de vista institucional. Pois como todos os Ministros e Ministros-substitutos devem ter notório conhecimento jurídico e comprovação de experiência profissional nessa área, se espera que isso os capacite a exercer a função de relator com a igual proficiência a despeito do cargo ocupado ou origem profissional. Além disso, como é determinado pelo regimento interno do TCU, a distribuição de processos ocorre por meio de sorteio e não em função de um expertise específico de algum relator em determinado aspecto dos processos de TCE, seja esse Ministro ou Ministro-substituto, de origem política ou técnica.

Já no que se refere a diferenças nas variáveis que se referem as sanções propostas por relatores em processos de TCE, foram consideradas sobretudo as análises conduzidas para cargo do relator. A partir disso, as análises de variância (ANOVA) indicaram diferenças significantes entre Ministros e Ministros-substitutos apenas para a variável \% multa 57. Ou seja, tais análises sugeriram diferenças significantes em função do cargo apenas para a porcentagem do valor da multa prevista pelo art. 57, lembrando que esse valor é calculado a partir de uma porcentagem do dano ao erário cometido pelo gestor responsável por recursos públicos.

Apesar das comparações a partir de análise de variância não terem indicado diferenças significantes nas demais variáveis que se referem as sanções previstas pelos artigos 57 e 58, os dados descritivos indicaram que essas tiveram valores maiores tanto para Ministros (Tabelas 29, 30, 31 e 32) quanto para relatores com cargo anterior político (Tabelas 47, 48, 49 e 50). No que se refere a sanção de inabilitação, conforme está descrito nas Tabelas 33 e 51, o mesmo tipo de 
tendência foi identificada, de modo que essa foi mais frequente em casos com relatores Ministros ou com cargo anterior político. Portanto, os dados descritivos sugerem que, de modo geral, as sanções proposta por Ministros e relatores de origem política tendem a ser relativamente mais severas do que a de Ministros-substitutos e técnicos. Também vale a pena destacar que esses resultados ressaltam que de fato ocorreu sobreposição entre as categorias Ministro e político e as categorias Ministro-substituto e técnico, pois apesar de diferenças em frequência, média e desvio padrão, as tendências gerais de resultados foram as mesmas.

Novamente é possível recorrer ao regimento interno do TCU (2015) como forma de explicar que as sanções propostas por relatores Ministros (e consequentemente políticos) foram relativamente mais severas do que aquelas propostas por Ministros-substitutos (e consequentemente técnicos). Tal como já foi discutido anteriormente, o art. 150 determina que não existem diferenças entre o tipo de processo de TCE que é designado para Ministro ou Ministro-substituto, já que a alocação de tais processos, ocorre por sorteio. No entanto, o art. 154 determina que processos relativos a recursos de revisão ou de reexame são sorteados exclusivamente entre os ministros, e tais recursos podem se referir a processos de TCE.

Apesar de carecerem dados mais sistemáticos, é possível inferir que de maneira geral, a maior parte dos processos que ocasionam pedidos de recursos ou reexame são relativamente mais graves ou envolvem maiores somas financeiras do que aqueles nos quais os responsáveis não interpelam recursos. Portanto, como tais processos, que são potencialmente mais graves ou que envolvem maiores quantias acabam sendo atribuídos exclusivamente a Ministros em função do art. 154, a média dos valores das sanções previstas pelos artigos 57 e 58, e a frequência da sanção de inabilitação propostas por Ministros acaba sendo superior a aquelas proposta por Ministros-substitutos. 
Essa interpretação encontra suporte nas medidas calculadas para a variável acórdãos total, já que essa variável foi calculada incluindo também os acórdãos relativos a pedidos de recurso (ver Tabela 1). Conforme é possível verificar na Tabela 27, a média de acórdãos produzidos para um processo de TCE foi em ligeiramente maior para Ministros do que para Ministros-substitutos em todas as amostras (e.g., Ministros, amostra total: 1,93 vs. Ministrossubstitutos, amostra total: 1,78). Como um maior número de acórdãos em um processo pode indicar a presença de acórdãos de recursos, é possível inferir que os Ministros analisaram processos mais gravosos, e esses tendem a requerer sanções mais severas. No entanto, como o número de recursos não foi investigado de modo descritivo mais específico e nem enquanto variável independente relacionada aos valores ou frequência das sanções em processos de TCE, esse aspecto deve ser investigado em mais detalhe em estudos posteriores.

A interpretação das diferenças entre sanções propostas por Ministros e Ministrossubstitutos pode ser complementada pelos resultados das regressões lineares, pois essas ajudam a identificar o quanto o cargo do relator, cargo anterior do relator e outras variáveis que descrevem características do processo influenciaram as variações nos valores das multas. De modo geral, considerando os três tipos de modelo de regressão que foram empregados para analisar as variáveis dependentes multa 57 e \% multa 57, os resultados sugeriram que a variável cargo está relacionada a variações nas variáveis que descrevem a multa prevista pelo art. 57. Como os coeficientes resultantes das comparações entre Ministro e Ministro-substituto foram positivos e significantes para a maioria das análises $(p<0,01 ; 0,05 ; 0,10)$, se constatou que a presença de um Ministro como relator do processo está associada a maiores valores das variáveis multa 57 e \% multa 57. 
Desse modo, apesar das evidências não serem robustas como as variações em função do colegiado onde o processo foi tramitado, também se identificou que variáveis antecedentes relacionadas a histórico de aprendizagem, no caso o cargo do relator, podem exercer influência nas sanções estabelecidas pelos relatores. Tal como discutido no Estudo 1, a ideologia de um magistrado pode ser interpretada como uma variável de histórico de vida em um sentido disposicional, desse modo, e a partir disso, se demonstrou que tal variável pode ser interpretada em ternos de histórico de aprendizagem. Nesse sentido, os resultados de estudos de análise econômica do direito que investigaram a influência de ideologia em comportamentos jurídicos, são comparáveis com o presente estudo, pois ambos investigaram o efeito de variáveis que se referem a histórico de aprendizagem de comportamentos jurídicos. Portanto, tomados em conjunto, os resultados do presente estudo corroboram regularidades identificadas em estudos sobre ideologia (Epstein et al., 2011, 2013, Lauderdale \& Clark, 2012, Sisk \& Heise, 2005) enfatizando que variáveis relacionadas a histórico de vida, estão relacionadas a diferenças individuais em comportamentos jurídicos.

No entanto, é necessário enfatizar que tais diferenças e influência foram pequenas, pois poucas das análises resultaram em efeitos significantes ou conclusivos em termos estatísticos. Em função disso, tais resultados devem ser interpretados e aplicados com parcimônia, porém, também abrem espaço para se investigar como outras variáveis que podem ser interpretadas em termos de histórico de aprendizagem e como essas podem influenciar os comportamentos jurídicos de relatores do TCU e magistrados de maneira geral.

Por fim, também foram conduzidas análises para verificar se existem variações nas sanções propostas pelos relatores dos processos de TCE em comparações entre sujeitos, ou seja, se investigou diretamente se existem diferenças individuais entre os comportamentos jurídicos 
dos relatores. A partir de uma análise de variância (ver Tabela 54), foram identificadas diferenças para as variáveis multa 57, \% multa 57 e inabilitação, sugerindo que diferentes relatores propõe sanções com características diferentes em comparação a seus pares. Novamente tais diferenças podem ser artifício de sorteio ou em função de determinado relator ter sido responsável por processos mais gravosos, e, desse modo, devem ser investigadas de modo mais detalhado.

Sobretudo no que se refere a variável \% multa 57, em função da forma como a multa baseada no art. 57 da lei orgânica do TCU (2002) é descrita, realmente existe grande espaço para variação entre indivíduos e processos, pois essa pode representar até $100 \%$ do valor do dano ao erário. Portanto, nesse caso específico esse tipo de variação nessa variável não pode ser apenas explicada em função de um artifício de sorteio, já que o normativo é extremamente vago quanto aos critérios para estabelecer um valor, o que enfatiza que realmente existem diferenças entre sujeitos nas sanções atribuídas pelos relatores a processos de TCE. No entanto, apesar de se ter identificado tal regularidade, as análises empregaram um número de casos relativamente pequeno, e os resultados careceram de mais robustez em termos estatísticos, e em função disso, também devem ser considerados de modo conservador. Portanto, a partir de tais considerações, estudos posteriores que comparem as sanções propostas por relatores de processos de TCE empregando um número maior de casos ou outros bancos de dados, pode ajudar a identificar características relevantes acerca desse fenômeno.

Novamente, o fato dessas diferenças entre comportamentos jurídicos dos relatores em função do cargo e do cargo ocupado anteriormente terem sido pequenas ou pouco consistentes, podem ser explicadas com auxílio dos documento oficiais que descrevem e estipulam as atribuições e características do cargo de Ministro e Ministro-substituto do TCU. De acordo com 
o art. 73 da constituição federal (Brasil, 1988) e do art. 51 do regimento interno do TCU (2015), é exigido que os Ministros e Ministros-substitutos tenham notórios conhecimentos jurídicos, contábeis, econômicos e financeiros ou de administração pública, além de comprovação de experiência no âmbito jurídico. Além disso, apenas com ressalva de algumas diferenças, como no caso da análise de recursos (cf. art. 154, TCU, 2015), as atribuições de Ministros e Ministrosubstitutos são praticamente as mesmas no que se referem ao função de relator de processos de TCE. Desse modo, mesmo com possíveis diferenças individuais quanto ao histórico particular de aprendizagem de comportamentos jurídicos de cada um dos relatores, o normativo do TCU e constituição federal acabam favorecendo que um grupo relativamente homogêneo de indivíduos seja selecionado para exercer os cargos de Ministros ou Ministros-substitutos. Ou seja, Ministros e Ministros-substitutos tendem a ter repertórios de comportamentos jurídicos muito semelhantes, especialmente no que se refere ao papel de relator de processos de TCE. Desse modo, novamente se ressalta que as práticas institucionais previstas pelas leis que amparam o TCU enquanto instituição (i.e., contingência planejada), realmente parecem influenciar de modo determinante os comportamentos jurídicos de seus ministros e ministros substitutos (contingência jurídica de fato).

Muitos estudos de análise econômica do direito visam explicar diferenças em decisões de magistrados com um foco excessivo em efeitos de ideologia (e.g., Epstein et al., 2011, 2013; Kim, 2009; Tamanha, 2009) e muitas vezes isso é realizado de maneira descontextualizada com a matéria do processo (cf. Cameron \& Kornhauser, 2015). Nesse sentido, uma das contribuições do presente trabalho foi de oferecer uma alternativa e um contraponto para esse tipo de literatura, já que esse adotou medidas para histórico de aprendizagem mais amparadas nas práticas diárias do magistrado, do que em um medida proximal ideologia política (partido político). Além disso, 
ao se focar especificamente em processos de TCE, foi possível verificar como as variáveis de histórico de aprendizagem influenciam decisões diante de uma matéria de processo específico (contexto e conteúdo específico). Por fim, o presente estudo também investigou a interação de variáveis relacionadas ao histórico de aprendizagem com aquelas que medem características do processo. Esse tipo de análise contribui para uma investigação mais precisa desse tipo de fenômeno, pois conforme destacam Clark e Lauderdale (2012) e Sisk e Heise (2005), os estudos de análise econômica do direito tradicionalmente tendem a investigar fenômenos desse tipo sem considerar a sua interação com outras variáveis relacionadas ao processo.

\section{Discussão Geral}

O presente estudo atendeu a dois principais propósitos mais amplos relacionados ao estudo de comportamentos de magistrados em colegiado, um teórico-metodológico e outro empírico. Para atender a questão teórico-metodológica, o primeiro estudo (Estudo 1) teve como objetivo desenvolver e apresentar um modelo econômico-comportamental operante para o estudo de decisões de magistrados em colegiado.

Em termo gerais, essa proposta apresentou uma integração entre elementos teóricos e metodológicos de análise econômica do direito e análise do comportamento, no qual foi empregado o arcabouço do BPM como base para o desenvolvimento do modelo. Tal modelo se baseou em um contingência tríplice modificada e se refere de modo mais específico para o estudo de comportamentos jurídicos de Ministros e Ministros-substitutos do TCU no papel de relatores, onde foram destacadas as interações relacionadas as sanções propostas por esses relatores para processos de TCE. O produto desse trabalho teórico também resultou em um modelo que oferece formas objetivas de identificar variáveis relacionadas ao comportamentos de magistrados além de permitir interpretar fenômenos estudados pela análise econômica do direito 
de modo mais preciso, de modo a possibilitar a comparação e integração de achados empíricos com estudos dessa área.

O segundo propósito do presente trabalho se referiu a investigação de questões empíricas acerca dos comportamentos jurídicos dos relatores de processos de TCE do TCU em colegiado, de modo que esse foi respondido a partir de dois estudos. A variáveis empregadas nos dois estudos empíricos (Estudo 2 e Estudo 3) foram delimitadas a partir do modelo teórico desenvolvido no Estudo 1. Portanto, além de atenderem ao intuito de investigar regularidades acerca das decisões em colegiados de Ministros e Ministros-substitutos do TCU, os estudos empíricos também serviram de teste ou para demonstrar a aplicação do modelo teórico aqui proposto.

A partir disso, no primeiro estudo empírico (Estudo 2) foram investigadas como o colegiado onde tramitou o processo (i.e., cenário de decisão) interage com variáveis que descrevem as características dos processos analisados para influenciar as sanções propostas pelos relatores de processos de TCE. Esse estudo identificou que o contexto da decisão está relacionado a diferenças entre decisões dos relatores e as variáveis que descrevem características do processo. Também foi possível atribuir variações nas sanções propostas pelos relatores a interação entre o contexto de decisão (i.e., colegiado) e as características do processo de TCE. De modo mais específico, o Estudo 2 identificou que de maneira geral, o Plenário enquanto variável de cenário está diretamente relacionado a ocorrência de sanções mais severas para os processos de TCE.

Por fim, utilizando uma metodologia semelhante ao estudo anterior, o Estudo 3 (segundo estudo empírico) investigou se as variáveis relacionadas a histórico de aprendizagem de comportamentos jurídicos (cargo e cargo anterior dos relatores) estão relacionadas a diferenças 
em característica dos processos e sanções propostas pelos relatores em processos TCE. Também foi investigado se a interação entre variáveis referentes ao tipo de cargo e cargo anterior dos relatores interagem com variáveis relacionadas a características do processo. E a partir disso, se constatou que algumas das diferenças identificadas em processos de TCE podem estar relacionadas a forma como os casos de TCE são distribuídos entre os relatores. Apesar das evidencias não terem sido conclusivas quanto as suas causas, os resultados também sugeriram diferenças e variações nas sanções propostas pelos relatores em função de seu cargo.

Tomados em conjunto os três estudos demonstraram que uma proposta econômicocomportamental operante pode contribuir teoricamente e empiricamente para o estudo de comportamentos jurídicos, sobretudo no contexto de colegiado. A partir desses estudos evidenciou-se que a qualificação de variáveis em termos funcionais a partir do modelo teórico aqui proposto permite formular perguntas de pesquisa e explicar os fenômenos relacionados a comportamentos jurídicos de modo objetivo e testável empiricamente. Especificamente no que se refere aos estudos empíricos, se constatou que os comportamentos jurídicos de Ministros e Ministros-substitutos do TCU não podem ser explicados e descritos meramente a partir de uma concepção normalista, pois esses podem e são influenciados por variáveis contextuais, e desse modo, apresentam diferenças individuais em suas práticas enquanto relatores.

Alguma das críticas que são tradicionalmente endereçadas a pesquisas de análise econômica do direito foram sumarizadas por Mitchell (2002). A autor destaca que muitos dos estudos de análise econômica do direito assumem uma ênfase em hipóteses de que o comportamento dos magistrados tende a desviar da norma esperada (lei como descrita). A partir disso, ainda de acordo com Mitchell, muitos autores sugerem amplas reformas do sistema judiciário em função dos resultados de seus estudos. No entanto, o autor critica a falta de 
precisão dos dados coletados relativos as decisões judiciais, pois esses apresentam vieses em relatar comportamentos de magistrados desviantes daqueles previstos pela lei (ou desvios ao padrão de racionalidade), mas raramente investigam regularidades que justificam o comportamento normativo (i.e., aquele que segue a norma). Além disso, o autor também destaca que existe uma carência de pesquisas acerca de diferenças individuais e situacionais para qualificar melhor os resultados dos estudos empíricos. Ou seja, faltam investigações acerca de quais são os variáveis que de fato contribuem para a ocorrência de comportamentos jurídicos que fogem ao padrão normativo, e que comportamentos jurídicos são esses.

Especificamente nos pontos apresentados por Mitchell (2002), que também encontram suporte em Cameron e Kornhauser (2015), Engle (2006) e Aguiar (2006), o presente estudo apresentou algumas soluções e alternativas viáveis que podem enriquecer as pesquisas da área e dirimir algumas das críticas e esse campo de estudo. Primeiramente, o presente estudo assumiu uma natureza exploratória e uma lógica relativamente mais indutiva acerca dos resultados, e, com isso, evitou vieses na formulação de perguntas de pesquisa e nas interpretações dos resultados em função de hipóteses preditivas que podem ser restritivas.

Além disso, o presente estudo investigou justamente os tipos de variáveis apontadas como frequentemente negligenciadas em estudos de análise econômica do direito (e.g., Cameron e Kornhauser, 2015; Mitchell, 2002). Isso foi alcançado justamente pelo presente trabalho ter se focado em um tipo específico de processo (TCE) e por ter investigado como variáveis de contexto e individuais dos relatores interagem com características do processo para influenciar os comportamentos jurídicos em colegiado. Ou seja, o presente trabalho evitou cair em resultados descontextualizados em termos das normas e leis relacionadas a comportamentos específicos dos 
relatores (e.g., multa 57), de diferenças individuais (i.e., histórico de aprendizagem), e de variáveis situacionais, tais como o tipo de colegiado e o conteúdo dos processos analisados.

Por fim, partindo de uma base epistemológica operante, variáveis antecedentes e consequentes interagem na determinação dos comportamentos, o que também se aplica ao caso de sanções propostas por relatores de processos de TCE. Portanto, baseando-se nisso, o presente estudo evitou interpretações reducionistas e imprecisas, já que investigou interações dos comportamentos jurídicos dos relatores com diversos elementos antecedentes e consequentes descritos pela contingência tríplice adaptada proposta pelo modelo econômico-comportamental operante para decisões em colegiado (ver Figura 2, Estudo 1).

\section{Considerações finais}

Um dos desafios do presente trabalho se referiu à natureza exploratória e originalidade do tema e objeto de estudo. Em função disso, algumas das variáveis empregadas no presente trabalho representaram desafios teóricos e metodológicos para o modelo. Um exemplo desse tipo de dificuldade se refere à variável cargo anterior do relator, que careceu de uma maior precisão para permitir uma investigação mais adequada acerca de variáveis relacionadas a histórico de aprendizagem.

Uma das limitações gerais do presente estudo se refere ao banco de dados empregado pelas análises dos estudos empíricos. Apesar de ter constituído uma amostra significativa dos casos disponíveis, o presente estudo teria se beneficiado de um maior número de casos para conduzir suas análises, sobretudo no que se refere a robustez das análises estatísticas, pois permitiria mais cruzamentos e comparações entre as variáveis, principalmente no caso das regressões lineares. Uma maior amostra também poderia ter permitido análises mais completas e conclusivas acerca de variáveis dependentes que ocorreram em frequência muito baixa, como foi 
o caso das variáveis relacionadas a sanção prevista pelo art. 58 (multa 58 e \% multa 58) e da sanção de inabilitação.

Ao se identificar limitações e contribuições do presente estudo, também se ressalta como esse poderá servir como base para trabalhos posteriores que empregarem o modelo aqui proposto, assim como outras abordagens baseadas em psicologia operante. Tais estudos poderão usar o presente trabalho como referência para a formulação de perguntas de pesquisa, desenvolver medidas e variáveis mais precisas relacionadas a comportamentos jurídicos, e também empregar as regularidades aqui descritas como base para a comparação para resultados de outros estudos empíricos.

A partir dos estudos aqui conduzidos, também é possível propor novas linhas de pesquisa baseando-se na variáveis delimitadas pelo modelo teórico (Estudo 1). Algumas propostas de estudos posteriores já foram apresentadas em outros pontos do trabalho, no entanto, de maneira geral, qualquer estudo que implemente mais variáveis que se refiram aos elementos centrais descritos pelo modelo teórico (Ver Figura 2) podem representar uma boa contribuição para o campo de investigação acerca de comportamentos jurídicos e para o refinamento do próprio modelo. Como exemplo de estudos posteriores é possível sugerir a comparação de medidas relacionadas a sanções propostas pelos relatores em intervalos de tempos distintos, pois isso pode demonstrar se os padrões de comportamentos jurídicos apresentam estabilidade ao longo do tempo. Também pode ser relevante estudar com mais precisão o efeito de variáveis informativas e utilitárias sobre os comportamentos jurídicos dos relatores, como por exemplo, impacto na mídia (informativa) do caso ou o número de páginas do processo (utilitária). Por fim, também é possível propor estudos que investiguem outras variáveis relacionadas a histórico de 
aprendizagem e diferenças individuais, tais como: tempo de serviço no TCU, proximidade da aposentadoria e idade relator do processo.

Além do presente estudo apresentar contribuições referentes a aspectos empíricos teóricos e metodológicos em um sentido acadêmico, também é necessário salientar possíveis implicações sociais e para a aplicação prática. Eventualmente toda a população brasileira pode ser diretamente afetada por decisões judiciais realizadas em colegiado. Especificamente no que se refere às decisões de Ministros e Ministros-substitutos do TCU, essas podem produzir um grande impacto na política e economia brasileira, pois esse é um dos mais importantes órgãos reguladores do país. Nesse sentido, o presente que pode ajudar a construir uma base instrumental para ajudar no melhor funcionamento de órgãos jurídicos e regulatórios e para o desenvolvimento de sistemas administrativos e legais mais eficientes, o que se relaciona a um dos principais intuitos da análise econômica do direito (cf. Posner, 1995, Gico, 2010) e análise comportamental do direito (cf. Aguiar, 2006, 2014). Tais contribuições podem ser alcançadas na medida em que as práticas jurídicas e administrativas estiverem menos sujeitas a vieses providos de fatores como cargos políticos ou carga de trabalho excessiva, e que tiverem sua eficiência, impacto social e institucional amparados empiricamente. Portanto, o presente estudo também contribuiu para a expansão do escopo explicativo e de aplicação da análise do comportamento sobre fenômenos humanos complexos e de grande relevância social, pois aplica o paradigma operante de modo integrado ao econômico, a partir de uma proposta teórica e metodológica original para a investigação de um fenômeno que ainda não foi abordado por esse tipo de literatura. 


\section{Referências}

Oliveira, A. (2016). Comportamento de gestores de recursos públicos: identificação de contingências previstas e vigentes relativas à prestação de contas (Tese de Doutorado), Universidade Federal de Brasília

Aguiar, J. C. (2006). Análise comportamental do direito: fundamentos para uma abordagem do direito como ciência comportamental aplicada (Tese de Doutorado), Universidade Federal de Santa Catarina.

Aguiar, J. C. (2013). O direito como sistema de contingências sociais. Revista da Faculdade de Direito da UFG, 37(02), 164-196.

Aguiar, J. C. (2014). Análise comportamental do direito: uma abordagem do direito como ciência do comportamento humano aplicada. Nomos, 34(2), 245-273.

Aidt, T. S. (2003). Economic analysis of corruption: a survey. The Economic Journal, 113, 632652.

Alencar, C. H. R., \& Gico Jr, I. (2010). When Crime Pays: Measuring Judicial Efficacy against Corruption in Brazil. Law \& Business Review of the Americas, 17(3), 415-434.

Alvarez, A. B. (2006). Análise econômica do direito: contribuições e desmistificações. Direito, Estado e Sociedade, 9(29), 49-68

Baum, W. M. (1999). Compreender o behaviorismo: ciência, comportamento e cultura. Porto Alegre, RS: Artes Médicas Sul.

Becker, G. S. (1993). Nobel lecture: the economic way of looking at behavior. The Journal of Political Economy, 101(3), 385-409.

Bickel, W. K., Odum, A. L., \& Madden, G. J. (1999). Impulsivity and cigarette smoking: delay discounting in current, never, and ex-smokers. Psychopharmacology, 146(4), 447-54. 
Bickel, W. K. \& Marsch L. A. (2001). Toward a behavioral economic understanding of drug dependence: delay discounting processes. Addiction, 96, 73-86.

Bobbio, N. (2004). A era dos direitos. Rio de Janeiro, RJ: Elsevier.

Boyd, C. L., Epstein, L., \& Martin, A. D. (2010). Untangling the causal effects of sex on Judging. American Journal of Political Science, 54(2), 389-411.

Brasil (2012). Constituição Federal (1988). Constituição da República Federativa do Brasil. Brasília, DF: Senado.

Cameron, C. M., \& Kornhouser, L. A., (2015). Rational choice attitudinalism? a review of Epstein, Landes and Posner's the behavior of federal judges: a theoretical and empirical study of rational choice. New York Law and Economics Research Paper, 15(15), 1-25.

Cavalcanti, P. R., Oliveira-Castro J. M., \& Foxall G. R. (2013). Individual differences in consumer buying patterns: a behavioral economic analysis. The Psychological Record, 63, 259-276.

Controladoria Geral da União (2013). Tomada de contas especial: perguntas e respostas. Disponível em: http://www.cgu.gov.br/Publicacoes/auditoria-e-fiscalizacao/arquivos/tomadadecontasespeci al.pdf

Cooter, R. D., (2000). Do good laws make good citizens? An economic analysis of internalized norms. Virginia Law Review, 86(8), 1577-1601.

Cooter, R. D., \& Rubinfeld, D. L. (1989). Economic analysis of legal disputes and their resolution. Journal of Economic Literature, 27(3), 1067-1097.

Cooter, R. D., \& Ulen, T. (2007) Law and Economics. 5ª ed. Reading, MA: Addison-Wesley.

Edwards, H. T. (2003). The effects of collegiality on judicial decision-making. University of Pennsylvania Law Review, 151(5), 1639-1690. 
Engle, E. (2009). Law and economics: theoretical puffery, exaggerated claims and counterfactual models. Journal of Jurisprudence, 2, 29-59.

Epstein, L., Landes, W. M., \& Posner, R. A. (2011). Why (and when) judges dissent. Journal of Legal Analysis, 3, 101-137.

Epstein, L., Landes, W. M., \& Posner, R. A. (2013). The behavior of federal judges: a theoretical and empirical study of rational choice. Cambridge, Massachusetts: Harvard University Press.

Field, A. (2009). Descobrindo a estatística com o SPSS. 2a ed. Porto Alegre, RS: Artmed

Foxall, G. R. (1990). Consumer psychology in behavioral perspective. Washington, DC: Beard Books.

Foxall, G. R. (1999). The substitutability of brands. Managerial and Decision Economics, 20, $241-257$

Foxall, G. R. (2002). Consumer behavior analysis: Critical perspectives in business and management. New York, NY: Routledge.

Foxall, G. R. (2004). What judges maximize: Toward an economic psychology of the judicial utility function. Liverpool Law Review, 25, 177-194.

Foxall, G. R. (2010). Theoretical and conceptual advances in consumer behavior analysis: Invitation to consumer behavior analysis. Journal of Organizational Behavior Management, 30, 92-109.

Foxall, G. R., Oliveira-Castro, J. M., \& Schrezenmaier, T. C. (2004). The behavioral economics of consumer brand choice: Patterns of reinforcement and utility maximization. Behavioural Processes, 66(3), 235-260. 
Foxall, G. R., Oliveira-Castro, J.M., James, V.K. \& Schrezenmaier, T.C (2007). The behavioral economics of brand choice. New York, NY: Palgrave Macmillan.

Foxall, G. R., Oliveira-Castro, J. M., James, V. K., Yani-de-Soriano, M. M., \& Sirgudsson, V. (2006). Consumer behavior analysis and social marketing: The case of environmental conservation. Behavior and Social Issues, 15, 101-124.

Gico Jr., I. T. (2010). Metodologia e epistemologia da análise econômica do direito. Economic Analysis of Law Review, 1(1) 7-32.

Green, L., \& Freed, D. E. (1998). Behavioral economics. In W. T. O'Donohue (Ed.), Learning and behavior therapy (pp. 274-300). Needham Heights, MA: Allyn \& Bacon.

Harnay, S., \& Marciano, A. (2009). Posner, economics and the law: from "law and economics" to an economic analysis of law. Journal of the History of Economic Thought, 31(02), 215232.

Harnay, S., \& Marciano, A. (2009). Should I help my neighbor? Self-interest, altruism and economic analyses of rescue laws, 28(2), 103-131.

Herrnstein, R. J. (1990). Behavior, reinforcement, and utility. Psychological Science, 1(4), $217-$ 224.

Hursh, S. R. (1980). Economic concepts for the analysis of behavior. Journal of Experimental Analysis of Behavior, 34, 219-238.

Hursh, S. R. (1984). Behavioral economics. Journal of the Experimental Analysis of Behavior, $42,435-452$.

Hursh, S. R., Madden, G. J., Spiga, R., DeLeon, I. G., \& Francisco, M. T. (2013). The translational utility of behavioral economics: the experimental analysis of consumption and choice. In Madden, G. J., Dube, W. V., Hackenberg, T. D., Hanley, G. P., \& Lattal, K. A. 
(Eds.), APA handbook of behavior analysis: vol. 2. translating principles into practice (pp. 191-224). Washington, DC: American Psychological Association.

Hursh, S. R., \& Silberberg, A. (2008). Economic demand and essential value. Psychological Review, 115(1), 186-198.

Jolls, C., Sunstein, C. R. \& Thaler, R. (1998). A behavioral approach to law and economics. Stanford Law Review, 50, 1471-1550.

Kagel, J. H., Battalio, R. C., \& Green, L. (1995). Economic choice theory: an experimental analysis of animal behavior. Cambridge, England: Cambridge University Press.

Kahneman, D. \& Tversky, A. (1984). Choices, values and frames. American Psychologist, 39(4), $341-350$.

Kastellac, J. P. (2007). Panel composition and judicial compliance on the US courts of appeals. The Journal of Law, Economics, \& Organization, 23(2), 421-441.

Kim, P. T. (2009). Deliberation and strategy on the United States courts of appeals: an empirical exploration of panel effects. University of Pennsylvania Law Review, 157, 1319-1381.

Lauderdale, B. E., \& Clark, T. S. (2012). The Supreme Court's many median justices. American Political Science Review, 16(4), 847-866.

Macaskill, A. C., \& Hackenberg, T. D. (2012). The sunk cost effect with pigeons: some determinants of decisions about persistence. Journal of the Experimental Analysis of Behavior, 97, 85-100.

Mankiw, G. N. (2013). Princípios de microeconomia. São Paulo, SP: Centage Learning

Miles, T. J., \& Sunstein, C. R. (2006). Do judges make regulatory policy? an empirical investigation of chevron. The University of Chicago Law Review, 73(3), 823-881. 
Mitchell, G. (2002). Taking behavioralism too seriously. the unwarranted pessimism of the new behavioral analysis of law. William \& Mary Law Review, 43(5), 1907-2021.

Moore, J. (2008). Conceptual foundations of radical behaviorism. Cornwall-on-Hudson, NY: Sloan Publishing.

Moreira, M. B., \& Medeiros, C. A. (2007). Princípios básicos de análise do comportamento. Porto Alegre, RS: Artmed

Navarro, A. D., \& Fantino, E. (2009). The sunk-time effect: An exploration. Journal of Behavior Decision Making, 22, 252-270.

Oliveira-Castro, J. M. (2011). Análise do comportamento do consumidor: escolha de marcas e extensões para comportamentos jurídicos. Trabalho não publicado.

Oliveira-Castro, J. M., Cavalcanti, P. R., \& Foxall, G. R. (2016). What consumers maximize: brand choice as a function of utilitarian and informational reinforcement. Managerial and Decisions Economics, 37, 360-37.

Oliveira-Castro, J. M., Cavalcanti, P. R., \& Foxall, G. R. (2015). What consumers maximize? the analysis of utility functions in light of the behavioral perspective model. In G. R. Foxall (Ed.), The routledge companion to consumer behaviour analysis (pp. 202-212). New York, NY: Routledge.

Oliveira-Castro, J. M., Foxall, G. R., \& Schrezenmaier, T. C. (2006). Consumer brand choice: individual and group analyses of demand elasticity. Journal of the Experimental Analysis of Behavior, 85, 147-166.

Oliveira-Castro, J. M., Foxall, G. R., Yani, J., \& Wells, V. K. (2011). A behavioural-economic analysis of the essential value of brands. Behavioural Processes, 87,106-114. 
Pinheiro, R. N., \& Oliveira-Castro, J. M. (2015). Contribuições da análise do comportamento do consumidor para a interpretação das escolhas das partes em audiência de conciliação. Revista Legislação do Trabalho, 79(6), 570-575.

Posner, R. A. (1975). The economic approach to law. Texas Law Review, 53, 757-782.

Posner, R. A. (1979). Utilitarianism, economics and legal theory. Journal of Legal Studies, 8, 103-140.

Posner, R. A. (1995). Overcoming Law. Cambridge, MA: Harvard University Press.

Posner, R. A. (2007). Economic analysis of law (7ª ed.). New York, NY: Aspen Publishers.

Reed, D. D., Niileksela, C. R., \& Kaplan, B. A. (2013). Behavioral economics: a tutorial for behavior analysts in practice. Behavior Analysis in Practice, 6(1), 34-54.

Ryle, Gilbert. (1949) The concept of mind. London, England: Hutchinson.

Santos, W. (2001). Dicionário jurídico brasileiro. Belo Horizonte, MG : Del Rey.

Skinner, B. F. (1992). Verbal behavior. Acton, MA: Copley Publishing Group.

Skinner, B.F. (2003). Ciência e comportamento humano. São Paulo, SP: Martins Fontes

Skinner, B. F. (2006). Sobre o behaviorismo. São Paulo, SP: Cultrix.

Sisk, G. C., \& Heise, M. (2005). Judges and ideology: public and academic debates about statistical measures. Northwestern University Law Review, 99(2), 743-803.

Stolarz-Fantino, S., Fantino, E., \& Kulik, J. (1996). The conjunction fallacy: differential incidence as a function of descriptive frames and educational context. Contemporary Educational Psychology, 21, 208-218.

Sunstein, C. R. (1997). Behavioral Analysis of Law. University of Chicago Law Review, 64, 1175-1195

Sunstein, C. R., Kahneman, D., \& Schkade, D. A. (1998). Assessing punitive damages (with notes on cognition and valuation in law). Yale Law Journal, 107(7), 2071-2153. 
Tamanaha, B. Z. (2009). The distorting slant in quantitative studies of judging. Boston College Law Review, 50, 685-758

Tribunal de Contas União (2002). O tribunal de Contas da União e a sua lei orgânica. Boletim do Tribunal de Contas da União Especial, 20, 8, 1-60.

Tribunal de Contas União (2015). Regimento interno do Tribunal de Contas da União. Boletim do Tribunal de Contas da União Especial, 33, 1, 1-95.

Tribunal Regional Federal - 1a Região. (2003). Regimento interno do Tribunal Regional Federal - $1^{a}$ Região. Brasília, DF: Tribunal Regional Federal.

Tribunal Superior Eleitoral. (2012). Regimento interno do Tribunal Superior Eleitoral. $6^{\mathrm{a}}$ ed. Brasília, DF: Tribunal Superior Eleitoral.

Todorov, J. C. (1987). A Constituição como metacontingência. Psicologia: Ciência e Profissão, 7(1), 9-13.

Todorov, J. C. (2005). Laws and the complex control of behavior. Behavior and Social Issues, 14, 86-91.

Todorov, J. C. (2007). A Psicologia como o estudo de interações. Psicologia: Teoria e Pesquisa, 23, 57-061.

Varian, H. R. (2010). Microeconomics: a modern approach. $8^{\mathrm{a}}$ ed. London, England: Norton \& Company. 


\section{Anexo I}

\section{Regressões para a variável multa 57 incluindo cargo do relator e cargo anterior do relator}

\section{$1^{0}$ modelo de regressão: Características do processo.}

\section{Amostra 1.}

\begin{tabular}{|l|r|r|r|c|}
\hline Model & $\mathrm{R}$ & $\mathrm{R}$ Square & $\begin{array}{l}\text { Adjusted R } \\
\text { Square }\end{array}$ & $\begin{array}{c}\text { Std. Error of the } \\
\text { Estimate }\end{array}$ \\
\hline 1 &, $413^{\mathrm{b}}$ &, 171 &, 150 &, 99403 \\
\hline
\end{tabular}

a. AMOSTRA $=$ Primeira_Amostra

b. Predictors: (Constant), Político_Dummy,

DURAÇÃO_PROCESSO_ANOS, Montate_Débito,

PROCESSŌS_APENSADOS, ACÓRDÃOS_TOTAL, Ministro_Dummy,

Montante_Analisado

\begin{tabular}{|c|c|c|c|c|c|c|}
\hline \multicolumn{7}{|c|}{ ANOVA $^{a, b}$} \\
\hline & & Sum of Squares & $d f$ & Mean Square & $\mathrm{F}$ & Sig. \\
\hline \multirow{3}{*}{1} & Regression & 56,139 & 7 & \multirow{3}{*}{$\begin{array}{r}8,020 \\
, 988\end{array}$} & \multirow[t]{3}{*}{8,117} & \multirow[t]{3}{*}{, $000^{c}$} \\
\hline & Residual & 272,713 & 276 & & & \\
\hline & Total & 328,853 & 283 & & & \\
\hline
\end{tabular}

a. AMOSTRA $=$ Primeira_Amostra

b. Dependent Variable: Multa Art57 LOG

c. Predictors: (Constant), Político_Dümmy, DURAÇÃO_PROCESSO_ANOS, Montate_Débito, PROCESSOS_APENSADOS, ACÓRDÃOS_TOTAL, Ministro_Dummy, Montante_Analisado

Coefficients $^{a, b}$

\begin{tabular}{|c|c|c|c|c|c|c|}
\hline \multirow{2}{*}{\multicolumn{2}{|c|}{ Model }} & \multicolumn{2}{|c|}{ Unstandardized Coefficients } & \multirow{2}{*}{$\begin{array}{l}\text { Standardized } \\
\text { Coefficients } \\
\text { Beta }\end{array}$} & \multirow[t]{2}{*}{$\mathrm{t}$} & \multirow[t]{2}{*}{ Sig. } \\
\hline & & $\mathrm{B}$ & Std. Error & & & \\
\hline \multirow{9}{*}{1} & (Constant) & 8,746 & ,144 & & 60,670 &, 000 \\
\hline & Montante_Analisado & $-4,353 E-008$ & ,000 &,- 116 & $-1,428$ & 154 \\
\hline & Montate_Débito & 7,421E-007 &, 000 & ,455 & 5,572 &, 000 \\
\hline & DURAÇÃO_PROCESSO_ANO & & & & & \\
\hline & $S$ &, 014 & ,026 & ,032 &, 518 & 605 \\
\hline & ACÓRDÃOS_TOTAL &,- 015 & ,068 &,- 014 &,- 216 & ,829 \\
\hline & PROCESSOS_APENSADOS &,- 009 & ,014 &,- 038 &,- 659 &, 510 \\
\hline & Ministro_Dummy & ,452 & 179 & ,200 & 2,524 & 012 \\
\hline & Político Dummy &,- 045 & 171 &,- 021 &,- 261 & ,794 \\
\hline
\end{tabular}

a. AMOSTRA = Primeira_Amostra

b. Dependent Variable: Multa_Art57_LOG 
Amostra 2.

Model Summarya

\begin{tabular}{|l|r|r|r|r|}
\hline Model & \multicolumn{1}{|c|}{$\mathrm{R}$} & $\mathrm{R}$ Square & \multicolumn{1}{|c|}{$\begin{array}{c}\text { Adjusted R } \\
\text { Square }\end{array}$} & $\begin{array}{c}\text { Std. Error of the } \\
\text { Estimate }\end{array}$ \\
\hline 1 &, $340^{\mathrm{b}}$ &, 115 &, 088 & 1,06057 \\
\hline
\end{tabular}

a. AMOSTRA = Segunda_Amostra

b. Predictors: (Constant), Político_Dummy, Montate_Débito,

PROCESSOS APENSADOS, Montante_Analisado,

ACÓRDÃOS_TTOTAL, DURAÇÃO_PROCEESSO_ANOS,

Ministro_Dummy

\begin{tabular}{|c|c|c|c|c|c|c|}
\hline \multicolumn{7}{|c|}{ ANOVA $^{a, b}$} \\
\hline & & Sum of Squares & $\mathrm{df}$ & Mean Square & $\mathrm{F}$ & Sig. \\
\hline \multirow{3}{*}{1} & Regression & 33,710 & 7 & 4,816 & 4,281 &, $000^{c}$ \\
\hline & Residual & 258,708 & 230 & 1,125 & & \\
\hline & Total & 292,419 & 237 & & & \\
\hline
\end{tabular}

a. AMOSTRA $=$ Segunda_Amostra

b. Dependent Variable: Multa_Art57_LOG

c. Predictors: (Constant), Político_Dummy, Montate_Débito, PROCESSOS_APENSADOS,

Montante_Analisado, ACÓRDÃOS_TOTAL, DURAÇÃO_PROCESSO_ANŌS, Ministro_Dummy

\section{Coefficients $^{a, b}$}

\begin{tabular}{|c|c|c|c|c|c|c|}
\hline \multirow{2}{*}{\multicolumn{2}{|c|}{ Model }} & \multicolumn{2}{|c|}{ Unstandardized Coefficients } & \multirow{2}{*}{$\begin{array}{l}\text { Standardized } \\
\text { Coefficients } \\
\text { Beta }\end{array}$} & \multirow[t]{2}{*}{$\mathrm{t}$} & \multirow[t]{2}{*}{ Sig. } \\
\hline & & B & Std. Error & & & \\
\hline \multirow{8}{*}{1} & (Constant) & 8,983 & , 163 & & 54,982 & ,000 \\
\hline & Montante_Analisado & $-1,864 \mathrm{E}-009$ &, 000 &,- 018 &,- 280 & ,780 \\
\hline & Montate_Débito & 2,479E-007 &, 000 & ,333 & 5,047 &, 000 \\
\hline & $\begin{array}{l}\text { DURAÇÃO_PROCESSO_A } \\
\text { NOS }\end{array}$ &,- 032 & ,034 &,- 073 &,- 925 & ,356 \\
\hline & ACÓRDÃOS_TOTAL & ,008 & 073 & ,008 &, 104 & ,917 \\
\hline & PROCESSOS_APENSADOS & ,023 & ,016 & ,094 & 1,422 & ,156 \\
\hline & Ministro_Dummy & ,294 & ,203 &, 129 & 1,445 &, 150 \\
\hline & Político_Dummy &,- 124 & , 198 &,- 056 &,- 629 &, 530 \\
\hline
\end{tabular}

a. AMOSTRA = Segunda_Amostra

b. Dependent Variable: Multa_Art57_LOG 
Amostra total.

Model Summary

\begin{tabular}{|l|r|r|r|c|}
\hline Model & \multicolumn{1}{|c|}{$\mathrm{R}$} & $\mathrm{R}$ Square & \multicolumn{1}{|c|}{$\begin{array}{c}\text { Adjusted R } \\
\text { Square }\end{array}$} & $\begin{array}{c}\text { Std. Error of the } \\
\text { Estimate }\end{array}$ \\
\hline 1 &, $337^{\mathrm{a}}$ &, 113 &, 101 & 1,03535 \\
\hline
\end{tabular}

a. Predictors: (Constant), Político_Dummy,

DURAÇÃO_PROCESSO_ANOS, Montante_Analisado,

PROCESSSŌS_APENSAD̄OS, Montate_Débito, ACÓRDÃOS_TOTAL,

Ministro_Dummy

ANOVA $^{\mathrm{a}}$

\begin{tabular}{|c|c|c|c|c|c|c|}
\hline \multicolumn{2}{|c|}{ Model } & Sum of Squares & df & Mean Square & $\mathrm{F}$ & Sig. \\
\hline \multirow{3}{*}{1} & Regression & 70,407 & 7 & 10,058 & 9,383 &, $000^{\mathrm{b}}$ \\
\hline & Residual & 550,984 & 514 & 1,072 & & \\
\hline & Total & 621,390 & 521 & & & \\
\hline
\end{tabular}

a. Dependent Variable: Multa_Art57_LOG

b. Predictors: (Constant), Político_Dümmy, DURAÇÃO_PROCESSO_ANOS,

Montante_Analisado, PROCESSŌS_APENSADOS, Montate_Débito, ACÓRDÃOS_TOTAL,

Ministro_Dummy

\section{Coefficients $^{a}$}

\begin{tabular}{|c|c|c|c|c|c|c|}
\hline \multirow{2}{*}{\multicolumn{2}{|c|}{ Model }} & \multicolumn{2}{|c|}{ Unstandardized Coefficients } & \multirow{2}{*}{$\begin{array}{c}\begin{array}{c}\text { Standardized } \\
\text { Coefficients }\end{array} \\
\text { Beta }\end{array}$} & \multirow[t]{2}{*}{$\mathrm{t}$} & \multirow[t]{2}{*}{ Sig. } \\
\hline & & $\mathrm{B}$ & Std. Error & & & \\
\hline \multirow{9}{*}{1} & (Constant) & 8,875 & 109 & & 81,647 & ,000 \\
\hline & Montante_Analisado & -1,527E-009 &, 000 &,- 011 &,- 244 & ,808 \\
\hline & Montate_Débito & 3,084E-007 & ,000 & ,316 & 7,163 & ,000 \\
\hline & DURAÇÃO_PROCESSO_A & P & & 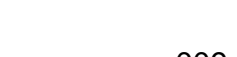 & $4 \cap 0$ & \\
\hline & NOS & -,004 & ,021 &,- 009 &,- 190 & 850, \\
\hline & ACÓRDÃOS_TOTAL & ,004 &, 050 &, 004 &, 083 & ,934 \\
\hline & PROCESSOS_APENSADOS & ,005 &, 011 & ,022 &, 507 & ,612 \\
\hline & Ministro_Dummy & ,363 &, 135 &, 160 & 2,684 & ,008 \\
\hline & Político_Dummy &,- 074 & 130 &,- 034 &,- 569 &, 569 \\
\hline
\end{tabular}

a. Dependent Variable: Multa_Art57_LOG 


\section{$2^{\circ}$ modelo de regressão: Motivos de instauração.}

\section{Amostra 1.}

Model Summarya

\begin{tabular}{|l|r|r|r|r|}
\hline Model & \multicolumn{1}{|c|}{$\mathrm{R}$} & $\mathrm{R}$ Square & \multicolumn{1}{c|}{$\begin{array}{c}\text { Adjusted } \mathrm{R} \\
\text { Square }\end{array}$} & $\begin{array}{c}\text { Std. Error of the } \\
\text { Estimate }\end{array}$ \\
\hline 1 &, $530^{\mathrm{b}}$ &, 281 &, 263 &, 92824 \\
\hline
\end{tabular}

a. AMOSTRA = Primeira_Amostra

b. Predictors: (Constant), MaisDeUmAto, Ministro Dummy,

Montate_Débito, Alínea_B, Alínea_A, Alínea_C, Político_Dummy

ANOVA $^{a, b}$

\begin{tabular}{|c|c|c|c|c|c|c|}
\hline \multicolumn{2}{|c|}{ Model } & Sum of Squares & $\mathrm{df}$ & Mean Square & $\mathrm{F}$ & Sig. \\
\hline \multirow{3}{*}{1} & Regression & 93,791 & 7 & 13,399 & 15,551 &, $000^{c}$ \\
\hline & Residual & 240,393 & 279 & ,862 & & \\
\hline & Total & 334,184 & 286 & & & \\
\hline
\end{tabular}

a. AMOSTRA = Primeira Amostra

b. Dependent Variable: Multa_Art57_LOG

c. Predictors: (Constant), MaisDeUmAto, Ministro_Dummy, Montate_Débito, Alínea_B, Alínea_A, Alínea_C, Político_Dummy

\begin{tabular}{|c|c|c|c|c|c|c|}
\hline \multicolumn{7}{|c|}{ Coefficients $^{a, b}$} \\
\hline \multirow{2}{*}{\multicolumn{2}{|c|}{ Model }} & \multicolumn{2}{|c|}{ Unstandardized Coefficients } & \multirow{2}{*}{$\begin{array}{c}\text { Standardized } \\
\text { Coefficients } \\
\text { Beta } \\
\end{array}$} & \multirow[t]{2}{*}{$t$} & \multirow[t]{2}{*}{ Sig. } \\
\hline & & $B$ & Std. Error & & & \\
\hline \multirow{8}{*}{1} & (Constant) & 9,499 &, 165 & & 57,414 &, 000 \\
\hline & Montate_Débito & $6,238 E-007$ &, 000 & ,387 & 7,565 &, 000 \\
\hline & Ministro_Dummy & ,385 &, 167 &, 170 & 2,310 & ,022 \\
\hline & Político_Dummy &,- 080 &, 159 &,- 037 &,- 503 & ,615 \\
\hline & Alínea_A & $-1,208$ & ,204 &,- 384 & $-5,919$ &, 000 \\
\hline & Alínea_B & $-1,190$ & ,259 &,- 267 & $-4,595$ &, 000 \\
\hline & Alínea_C &,- 794 &, 169 &,- 345 & $-4,698$ &, 000 \\
\hline & MaisDeUmAto &,- 629 &, 170 &,- 271 & $-3,698$ & ,000 \\
\hline
\end{tabular}

a. AMOSTRA = Primeira_Amostra

b. Dependent Variable: Multa_Art57_LOG 
Amostra 2.

Model Summarya

\begin{tabular}{|l|r|r|r|r|}
\hline Model & $R$ & $R$ Square & \multicolumn{1}{|l|}{$\begin{array}{l}\text { Adjusted R } \\
\text { Square }\end{array}$} & $\begin{array}{l}\text { Std. Error of the } \\
\text { Estimate }\end{array}$ \\
\hline 1 &, $387^{\mathrm{b}}$ &, 150 &, 127 & 1,00057 \\
\hline
\end{tabular}

a. AMOSTRA $=$ Segunda_Amostra

b. Predictors: (Constant), MaisDeUmAto, Montate_Débito,

Ministro_Dummy, Alínea_B, Alínea_A, Político_Dummy, Alínea_C

ANOVA $^{a, b}$

\begin{tabular}{|c|c|c|c|c|c|c|}
\hline \multicolumn{2}{|c|}{ Model } & Sum of Squares & $\mathrm{df}$ & Mean Square & $\mathrm{F}$ & Sig. \\
\hline \multirow{3}{*}{1} & Regression & 45,773 & 7 & 6,539 & 6,531 &, $000^{c}$ \\
\hline & Residual & 260,298 & 260 & 1,001 & & \\
\hline & Total & 306,070 & 267 & & & \\
\hline
\end{tabular}

a. $A M O S T R A=$ Segunda_Amostra

b. Dependent Variable: Multa_Art57_LOG

c. Predictors: (Constant), Mais̄DeUmAto, Montate_Débito, Ministro_Dummy, Alínea_B, Alínea_A,

Político_Dummy, Alínea_C

Coefficients $^{a, b}$

\begin{tabular}{|c|c|c|c|c|c|c|}
\hline \multirow{2}{*}{\multicolumn{2}{|c|}{ Model }} & \multicolumn{2}{|c|}{ Unstandardized Coefficients } & \multirow{2}{*}{$\begin{array}{l}\text { Standardized } \\
\text { Coefficients } \\
\text { Beta }\end{array}$} & \multirow[t]{2}{*}{$\mathrm{t}$} & \multirow[t]{2}{*}{ Sig. } \\
\hline & & $\mathrm{B}$ & Std. Error & & & \\
\hline \multirow{8}{*}{1} & (Constant) & 9,419 & ,211 & & 44,737 & ,000 \\
\hline & Montate_Débito & $2,110 \mathrm{E}-007$ &, 000 & ,280 & 4,811 & ,000 \\
\hline & Ministro_Dummy & ,242 & ,183 &, 111 & 1,321 & ,188 \\
\hline & Político_Dummy &,- 121 & ,180 &,- 056 &,- 670 &, 504 \\
\hline & Alínea_A &,- 721 & ,245 &,- 235 & $-2,943$ & ,004 \\
\hline & Alínea_B &,- 818 & ,304 &,- 187 & $-2,694$ & ,008 \\
\hline & Alínea_C &,- 465 & ,213 &,- 201 & $-2,190$ & ,029 \\
\hline & MaisDeUmAto &,- 223 & 209 &,- 101 & $-1,067$ & ,287 \\
\hline
\end{tabular}

a. AMOSTRA $=$ Segunda_Amostra

b. Dependent Variable: Multa_Art57_LOG 


\section{Amostra total}

\begin{tabular}{|l|r|r|r|r|}
\hline Model & $\mathrm{R}$ & $\mathrm{R}$ Square & $\begin{array}{c}\text { Adjusted R } \\
\text { Square }\end{array}$ & $\begin{array}{c}\text { Std. Error of the } \\
\text { Estimate }\end{array}$ \\
\hline 1 &, $428^{\mathrm{a}}$ &, 183 &, 173 &, 97790 \\
\hline
\end{tabular}

a. Predictors: (Constant), MaisDeUmAto, Político_Dummy,

Montate_Débito, Alínea_B, Alínea_A, Ministro_Dümmy, Alínea_C

ANOVA $^{a}$

\begin{tabular}{|rl|r|r|r|r|r|}
\hline \multicolumn{1}{|l|}{} & Sum of Squares & df & Mean Square & \multicolumn{1}{c|}{ F } & Sig. \\
\hline & Regression & 117,303 & 7 & 16,758 & 17,524 &, $000^{\mathrm{b}}$ \\
1 & Residual & 523,087 & 547 &, 956 & & \\
& Total & 640,390 & 554 & & & \\
\hline
\end{tabular}

a. Dependent Variable: Multa_Art57_LOG

b. Predictors: (Constant), MaisDeUmAto, Político_Dummy, Montate_Débito, Alínea_B, Alínea_A, Ministro_Dummy, Alínea_C

Coefficients $^{a}$

\begin{tabular}{|c|c|c|c|c|c|c|}
\hline \multirow{2}{*}{\multicolumn{2}{|c|}{ Model }} & \multicolumn{2}{|c|}{ Unstandardized Coefficients } & \multirow{2}{*}{$\begin{array}{l}\text { Standardized } \\
\text { Coefficients } \\
\text { Beta }\end{array}$} & \multirow[t]{2}{*}{$\mathrm{t}$} & \multirow[t]{2}{*}{ Sig. } \\
\hline & & $\mathrm{B}$ & Std. Error & & & \\
\hline \multirow{8}{*}{1} & (Constant) & 9,502 & ,133 & & 71,674 & ,000 \\
\hline & Montate_Débito & $2,839 E-007$ &, 000 & ,290 & 7,448 & ,000 \\
\hline & Ministro_Dummy & ,290 & ,125 &, 131 & 2,323 & 021 \\
\hline & Político_Dummy &,- 082 & , 120 &,- 038 &,- 678 & ,498 \\
\hline & Alínea_A &,- 959 & ,159 &,- 309 & $-6,030$ &, 000 \\
\hline & Alínea_B & $-1,017$ & ,200 &,- 230 & $-5,082$ & ,000 \\
\hline & Alínea_C &,- 626 & ,135 &,- 271 & $-4,648$ &, 000 \\
\hline & MaisDeUmAto &,- 427 & ,134 &,- 189 & $-3,193$ & ,001 \\
\hline
\end{tabular}

a. Dependent Variable: Multa_Art57_LOG 


\section{$3^{\circ}$ modelo de regressão: Cargo do gestor.}

\section{Amostra 1.}

\begin{tabular}{|l|r|r|r|r|}
\hline Model & \multicolumn{1}{|c|}{ Model Summary } \\
\hline 1 &, $472^{\mathrm{b}}$ &, 223 & \multicolumn{1}{c|}{$\begin{array}{c}\text { Adjusted R } \\
\text { Square }\end{array}$} & $\begin{array}{c}\text { Std. Error of the } \\
\text { Estimate }\end{array}$ \\
\hline
\end{tabular}

a. AMOSTRA = Primeira_Amostra

b. Predictors: (Constant), Outros_Cargos, Ministro_Dummy,

Montate_Débito, Presidente_Diretor, Político_Dummy

\section{ANOVA $^{\mathrm{a}, \mathrm{b}}$}

\begin{tabular}{|c|c|c|c|c|c|c|}
\hline \multicolumn{2}{|c|}{ Model } & Sum of Squares & df & Mean Square & $\mathrm{F}$ & Sig. \\
\hline \multirow{3}{*}{1} & Regression & 70,222 & 5 & 14,044 & 14,289 &, $000^{c}$ \\
\hline & Residual & 244,728 & 249 & ,983 & & \\
\hline & Total & 314,950 & 254 & & & \\
\hline
\end{tabular}

a. AMOSTRA $=$ Primeira_Amostra

b. Dependent Variable: Multa_Art57_LOG

c. Predictors: (Constant), Outros_Cargos, Ministro_Dummy, Montate_Débito, Presidente_Diretor, Político_Dummy

\section{Coefficients $^{a, b}$}

\begin{tabular}{|c|c|c|c|c|c|c|}
\hline \multirow{2}{*}{\multicolumn{2}{|c|}{ Model }} & \multicolumn{2}{|c|}{ Unstandardized Coefficients } & \multirow{2}{*}{$\begin{array}{c}\text { Standardized } \\
\text { Coefficients } \\
\text { Beta }\end{array}$} & \multirow[t]{2}{*}{$\mathrm{t}$} & \multirow[t]{2}{*}{ Sig. } \\
\hline & & $\mathrm{B}$ & Std. Error & & & \\
\hline \multirow{6}{*}{1} & (Constant) & 8,622 &, 114 & & 75,514 & ,000 \\
\hline & Montate_Débito & 5,887E-007 &, 000 & ,372 & 6,546 &, 000 \\
\hline & Ministro_Dummy & ,496 &, 184 & ,214 & 2,692 & ,008 \\
\hline & Político_Dummy &,- 135 &, 177 &,- 060 &,- 760 & ,448 \\
\hline & Presidente_Diretor &, 128 &, 170 & ,044 &, 753 & ,452 \\
\hline & Outros_Cargos &, 666 &, 163 & ,236 & 4,098 &, 000 \\
\hline
\end{tabular}

a. AMOSTRA $=$ Primeira_Amostra

b. Dependent Variable: Multa_Art57_LOG 
Amostra 2.

Model Summarya

\begin{tabular}{|l|r|r|r|r|}
\hline Model & $R$ & $R$ Square & \multicolumn{1}{|l|}{$\begin{array}{l}\text { Adjusted R } \\
\text { Square }\end{array}$} & $\begin{array}{l}\text { Std. Error of the } \\
\text { Estimate }\end{array}$ \\
\hline 1 &, $325^{\mathrm{b}}$ &, 106 &, 085 & 1,01703 \\
\hline
\end{tabular}

a. $A M O S T R A=$ Segunda_Amostra

b. Predictors: (Constant), Outros_Cargos, Ministro_Dummy, Montate_Débito, Presidente_Diretor, Político_Dummy

ANOVA $^{a, b}$

\begin{tabular}{|c|c|c|c|c|c|c|}
\hline \multicolumn{2}{|c|}{ Model } & Sum of Squares & $\mathrm{df}$ & Mean Square & $\mathrm{F}$ & Sig. \\
\hline & Regression & 27,085 & 5 & 5,417 & 5,237 &, $000^{c}$ \\
\hline 1 & Residual & 229,625 & 222 & 1,034 & & \\
\hline & Total & 256,711 & 227 & & & \\
\hline
\end{tabular}

a. AMOSTRA = Segunda_Amostra

b. Dependent Variable: Multa_Art57_LOG

c. Predictors: (Constant), Outros_Cargos, Ministro_Dummy, Montate_Débito, Presidente_Diretor, Político_Dummy

\section{Coefficients $^{\mathrm{a}, \mathrm{b}}$}

\begin{tabular}{|l|r|r|r|r|r|}
\hline Model & \multicolumn{2}{|c|}{ Unstandardized Coefficients } & \multicolumn{2}{c|}{$\begin{array}{c}\text { Standardized } \\
\text { Coefficients }\end{array}$} & Sig. \\
\cline { 2 - 5 } & B & Std. Error & Beta & \\
\hline (Constant) & 9,045 &, 124 &, 000 \\
Montate_Débito & $2,073 \mathrm{E}-007$ &, 000 &, 298 & 4,669 &, 000 \\
Ministro_Dummy &, 276 &, 194 &, 128 & 1,424 &, 156 \\
Político_Dummy &,- 113 &, 194 &,- 052 &,- 581 &, 562 \\
Presidente_Diretor &,- 201 &, 163 &,- 082 & $-1,233$ &, 219 \\
Outros_Cargos &, 188 &, 178 &, 071 & 1,060 &, 290 \\
\hline
\end{tabular}
a. $A M O S T R A=$ Segunda_Amostra
b. Dependent Variable: Multa_Art57_LOG 
Amostra total

Model Summary

\begin{tabular}{|l|r|r|r|c|}
\hline Model & \multicolumn{1}{|c|}{$\mathrm{R}$} & $\mathrm{R}$ Square & \multicolumn{1}{|c|}{$\begin{array}{c}\text { Adjusted } \mathrm{R} \\
\text { Square }\end{array}$} & $\begin{array}{c}\text { Std. Error of the } \\
\text { Estimate }\end{array}$ \\
\hline 1 &, $365^{\mathrm{a}}$ &, 133 &, 124 & 1,01934 \\
\hline
\end{tabular}

a. Predictors: (Constant), Outros_Cargos, Ministro_Dummy,

Montate_Débito, Presidente_Diretor, Político_Dummy

\section{ANOVAa}

\begin{tabular}{|c|c|c|c|c|c|c|}
\hline \multicolumn{2}{|c|}{ Model } & Sum of Squares & df & Mean Square & $\mathrm{F}$ & Sig. \\
\hline \multirow{3}{*}{1} & Regression & 76,173 & 5 & 15,235 & 14,662 &, $000^{b}$ \\
\hline & Residual & 495,628 & 477 & 1,039 & & \\
\hline & Total & 571,801 & 482 & & & \\
\hline
\end{tabular}

a. Dependent Variable: Multa_Art57_LOG

b. Predictors: (Constant), Outros_Cargos, Ministro_Dummy, Montate_Débito, Presidente_Diretor, Político_Dummy

\section{Coefficients $^{\mathrm{a}}$}

\begin{tabular}{|l|r|r|r|r|r|}
\hline Model & \multicolumn{2}{|c|}{ Unstandardized Coefficients } & \multicolumn{2}{c|}{$\begin{array}{c}\text { Standardized } \\
\text { Coefficients }\end{array}$} & Sig. \\
\cline { 2 - 5 } & B & Std. Error & Beta & \\
\hline (Constant) & 8,835 &, 085 & 104,123 &, 000 \\
Montate_Débito & $2,846 \mathrm{E}-007$ &, 000 &, 305 & 7,114 &, 000 \\
Ministro_Dummy &, 361 &, 135 &, 162 & 2,667 &, 008 \\
Político_Dummy &,-- 082 &, 133 &,- 038 &,- 621 &, 535 \\
Presidente_Diretor &, 009 &, 118 &, 003 &, 077 &, 939 \\
Outros_Cargos &, 474 &, 121 &, 173 & 3,917 &, 000 \\
\hline
\end{tabular}

a. Dependent Variable: Multa_Art57_LOG 


\section{Regressões para a variável \% multa 57 incluindo cargo do relator e cargo anterior do relator}

$1^{\circ}$ modelo de regressão: Características do processo.

Amostra 1.

\begin{tabular}{|l|r|r|r|r|}
\hline Model & \multicolumn{1}{|c|}{ Model Summarya } \\
\hline 1 &, $423^{\mathrm{b}}$ &, 179 & \multicolumn{1}{c|}{$\begin{array}{c}\text { Adjusted R } \\
\text { Square }\end{array}$} & $\begin{array}{c}\text { Std. Error of the } \\
\text { Estimate }\end{array}$ \\
\hline
\end{tabular}

a. AMOSTRA = Primeira_Amostra

b. Predictors: (Constant), Político_Dummy,

DURAÇÃO_PROCESSO_ANOS, Montate_Débito,

PROCESSOS_APENSADOS, ACÓRDÃOS_TOTAL, Ministro_Dummy,

Montante_Analisado

ANOVA $^{\mathrm{a}, \mathrm{b}}$

\begin{tabular}{|c|c|c|c|c|c|c|}
\hline \multicolumn{2}{|c|}{ Model } & Sum of Squares & df & Mean Square & $\mathrm{F}$ & Sig. \\
\hline \multirow{3}{*}{1} & Regression & 53,492 & 7 & \multirow{3}{*}{$\begin{array}{r}7,642 \\
, 890\end{array}$} & \multirow[t]{3}{*}{8,584} & \multirow[t]{3}{*}{, $000^{c}$} \\
\hline & Residual & 245,709 & 276 & & & \\
\hline & Total & 299,201 & 283 & & & \\
\hline
\end{tabular}

a. AMOSTRA $=$ Primeira_Amostra

b. Dependent Variable: Porcentagem_MultaArt57_LOG

c. Predictors: (Constant), Político_Dummy, DURAÇÃO_PROCESSO_ANOS, Montate_Débito,

PROCESSOS_APENSADOS, ACÓRDÃOS_TOTAL, Ministro_Dummy, Montante_Analisado

Coefficients $^{a, b}$

\begin{tabular}{|c|c|c|c|c|c|c|}
\hline \multirow[t]{2}{*}{ Mode } & & \multicolumn{2}{|c|}{ Unstandardized Coefficients } & \multirow{2}{*}{$\begin{array}{c}\text { Standardized } \\
\text { Coefficients } \\
\text { Beta } \\
\end{array}$} & \multirow[t]{2}{*}{$\mathrm{t}$} & \multirow[t]{2}{*}{ Sig. } \\
\hline & & $\mathrm{B}$ & Std. Error & & & \\
\hline \multirow{9}{*}{1} & (Constant) & 2,489 & , 137 & & 18,192 & ,000 \\
\hline & Montante_Analisado & 7,211E-008 & 000 & ,201 & 2,492 & 013 \\
\hline & Montate_Débito & $-7,585 \mathrm{E}-007$ &, 000 &,- 487 & $-6,000$ &, 000 \\
\hline & DURAÇÃO_PROCESSO_A & 021 & 025 & 053 & 857 & 392 \\
\hline & NOS & , & D & | & | & , \\
\hline & ACÓRDÃOS_TOTAL &,- 131 & 065 &,- 130 & $-2,035$ & ,043 \\
\hline & PROCESSOS_APENSADOS & ,012 & ,013 &, 053 & ,924 & ,356 \\
\hline & Ministro_Dummy & ,370 & , 170 &, 172 & 2,178 & ,030 \\
\hline & Político_Dummy &,- 186 & , 162 &,- 091 & $-1,145$ & ,253 \\
\hline
\end{tabular}

a. AMOSTRA = Primeira_Amostra

b. Dependent Variable: Porcentagem_MultaArt57_LOG 
Amostra 2.

Model Summarya

\begin{tabular}{|l|r|r|r|r|}
\hline Model & $R$ & $R$ Square & \multicolumn{1}{|c|}{$\begin{array}{c}\text { Adjusted R } \\
\text { Square }\end{array}$} & $\begin{array}{c}\text { Std. Error of the } \\
\text { Estimate }\end{array}$ \\
\hline 1 &, $471^{\mathrm{b}}$ &, 222 &, 198 &, 84162 \\
\hline
\end{tabular}

a. AMOSTRA $=$ Segunda_Amostra

b. Predictors: (Constant), Político_Dummy, Montate_Débito,

PROCESSOS_APENSADOS, Montante_Analisado,

ACÓRDÃOS_TOTAL, DURAÇÃO_PROCESSO_ANOS,

Ministro_Dummy

ANOVA ${ }^{a, b}$

\begin{tabular}{|rl|r|r|r|r|r|}
\hline Model & & Sum of Squares & \multicolumn{1}{c|}{ df } & Mean Square & F & \multicolumn{1}{c|}{ Sig. } \\
\hline \multirow{4}{*}{1} & Regression & 46,357 & 7 & 6,622 & 9,349 &, $000^{c}$ \\
& Residual & 162,915 & 230 &, 708 & & \\
Total & 209,272 & 237 & & & \\
\hline
\end{tabular}

a. $A M O S T R A=$ Segunda_Amostra

b. Dependent Variable: Porcentagem_MultaArt57_LOG

c. Predictors: (Constant), Político_Dummy, Montate_Débito, PROCESSOS_APENSADOS,

Montante_Analisado, ACÓRDÃOS_TOTAL, DURAÇÃO_PROCESSO_ANOS, Ministro_Dummy

Coefficients $^{\mathrm{a}, \mathrm{b}}$

\begin{tabular}{|c|c|c|c|c|c|c|}
\hline \multirow[t]{2}{*}{ Mode } & & \multicolumn{2}{|c|}{ Unstandardized Coefficients } & \multirow{2}{*}{$\begin{array}{c}\text { Standardized } \\
\text { Coefficients }\end{array}$} & \multirow[t]{2}{*}{$\mathrm{t}$} & \multirow[t]{2}{*}{ Sig. } \\
\hline & & B & Std. Error & & & \\
\hline \multirow{9}{*}{1} & (Constant) & 2,510 & , 130 & & 19,360 & 000 \\
\hline & Montante_Analisado & $-8,739 E-009$ & 000 &,- 100 & $-1,653$ & 100 \\
\hline & Montate_Débito & $-2,291 \mathrm{E}-007$ &, 000 &,- 363 & $-5,878$ & ,000 \\
\hline & DURAÇÃO_PROCESSO_A & -026 & 027 & -071 & -971 & 333 \\
\hline & NOS & & & & & \\
\hline & ACÓRDÃOS_TOTAL &,- 076 & ,058 &,- 092 & $-1,307$ & ,192 \\
\hline & PROCESSOS_APENSADOS & 010 & 013 & 048 & ,777 & ,438 \\
\hline & Ministro_Dummy & ,321 & , 161 & , 166 & 1,987 & ,048 \\
\hline & Político_Dummy &,- 105 & 157 &,- 056 &,- 673 & ,502 \\
\hline
\end{tabular}

a. AMOSTRA = Segunda_Amostra

b. Dependent Variable: Porcentagem_MultaArt57_LOG 
Amostra total.

Model Summary

\begin{tabular}{|l|r|r|r|c|}
\hline Model & \multicolumn{1}{|c|}{$\mathrm{R}$} & $\mathrm{R}$ Square & \multicolumn{1}{|c|}{$\begin{array}{c}\text { Adjusted R } \\
\text { Square }\end{array}$} & $\begin{array}{c}\text { Std. Error of the } \\
\text { Estimate }\end{array}$ \\
\hline 1 &, $408^{\mathrm{a}}$ &, 167 &, 155 &, 90803 \\
\hline
\end{tabular}

a. Predictors: (Constant), Político_Dummy,

DURAÇÃO_PROCESSO_ANOS, Montante_Analisado, PROCESSOS_APENSADOS, Montate_Débito, ACÓRDÃOS_TOTAL, Ministro_Dummy

ANOVA ${ }^{a}$

\begin{tabular}{|c|c|c|c|c|c|c|}
\hline \multicolumn{2}{|c|}{ Model } & Sum of Squares & $\mathrm{df}$ & Mean Square & $\mathrm{F}$ & Sig. \\
\hline \multirow{3}{*}{1} & Regression & 84,681 & 7 & 12,097 & 14,672 &, $000^{\mathrm{b}}$ \\
\hline & Residual & 423,799 & 514 & ,825 & & \\
\hline & Total & 508,480 & 521 & & & \\
\hline
\end{tabular}

a. Dependent Variable: Porcentagem_MultaArt57_LOG

b. Predictors: (Constant), Político_Dummy, DURAÇÃO_PROCESSO_ANOS, Montante_Analisado, PROCESSOS_APENSADOS, Montate_Débito, ACÓRDÃOS_TOTAL, Ministro_Dummy

Coefficients $^{\mathrm{a}}$

\begin{tabular}{|c|c|c|c|c|c|c|}
\hline \multirow{2}{*}{\multicolumn{2}{|c|}{ Model }} & \multicolumn{2}{|c|}{ Unstandardized Coefficients } & \multirow{2}{*}{$\begin{array}{c}\text { Standardized } \\
\text { Coefficients } \\
\text { Beta }\end{array}$} & \multirow[t]{2}{*}{$\mathrm{t}$} & \multirow[t]{2}{*}{ Sig. } \\
\hline & & $B$ & Std. Error & & & \\
\hline \multirow{9}{*}{1} & (Constant) & 2,471 & 095 & & 25,917 &, 000 \\
\hline & Montante_Analisado & $-6,509 E-009$ &, 000 &,- 050 & $-1,185$ & ,237 \\
\hline & Montate_Débito & $-2,910 \mathrm{E}-007$ &, 000 &,- 329 & $-7,707$ &, 000 \\
\hline & DURAÇÃO_PROCESSO_A & 006 & 018 & 016 & 338 & 735 \\
\hline & NOS & & & & & \\
\hline & ACÓRDÃOS_TOTAL &,- 124 & 044 &,- 134 & $-2,839$ & ,005 \\
\hline & PROCESSOS_APENSADOS & ,009 & 009 & 043 & 1,021 & ,308 \\
\hline & Ministro_Dummy & ,382 & , 118 & , 186 & 3,223 & 001 \\
\hline & Político_Dummy &,- 159 & ,114 &,- 080 & $-1,391$ & ,165 \\
\hline
\end{tabular}

a. Dependent Variable: Porcentagem_MultaArt57_LOG 


\section{$2^{\circ}$ modelo de regressão: Motivos de instauração.}

\section{Amostra 1.}

\begin{tabular}{|l|r|r|r|r|}
\hline Model & \multicolumn{1}{|c|}{ Model Summarya } \\
\hline 1 &, $466^{\mathrm{b}}$ &, 217 & \multicolumn{1}{c|}{$\begin{array}{c}\text { Adjusted R } \\
\text { Square }\end{array}$} & $\begin{array}{c}\text { Std. Error of the } \\
\text { Estimate }\end{array}$ \\
\hline
\end{tabular}

a. AMOSTRA = Primeira_Amostra

b. Predictors: (Constant), MaisDeUmAto, Ministro_Dummy,

Montate_Débito, Alínea_B, Alínea_A, Alínea_C, Político_Dummy

\section{ANOVA ${ }^{\mathrm{a}, \mathrm{b}}$}

\begin{tabular}{|c|c|c|c|c|c|c|}
\hline \multicolumn{2}{|c|}{ Model } & Sum of Squares & $\mathrm{df}$ & Mean Square & $\mathrm{F}$ & Sig. \\
\hline \multirow{3}{*}{1} & Regression & 65,766 & 7 & 9,395 & 11,033 &, $000^{\circ}$ \\
\hline & Residual & 237,574 & 279 & ,852 & & \\
\hline & Total & 303,340 & 286 & & & \\
\hline
\end{tabular}

a. $A M O S T R A=$ Primeira_Amostra

b. Dependent Variable: Porcentagem_MultaArt57_LOG

c. Predictors: (Constant), MaisDeUmAto, Ministro_Dummy, Montate_Débito, Alínea_B, Alínea_A, Alínea_C, Político_Dummy

\begin{tabular}{|c|c|c|c|c|c|c|}
\hline \multicolumn{7}{|c|}{ Coefficients $^{a, b}$} \\
\hline \multirow{2}{*}{\multicolumn{2}{|c|}{ Model }} & \multicolumn{2}{|c|}{ Unstandardized Coefficients } & \multirow{2}{*}{$\begin{array}{c}\text { Standardized } \\
\text { Coefficients } \\
\text { Beta }\end{array}$} & \multirow[t]{2}{*}{$\mathrm{t}$} & \multirow[t]{2}{*}{ Sig. } \\
\hline & & $\mathrm{B}$ & Std. Error & & & \\
\hline \multirow{8}{*}{1} & (Constant) & 2,847 &, 164 & & 17,311 &, 000 \\
\hline & Montate_Débito & $-5,628 \mathrm{E}-007$ &, 000 &,- 366 & $-6,866$ &, 000 \\
\hline & Ministro_Dummy & ,360 &, 166 & ,167 & 2,170 & ,031 \\
\hline & Político_Dummy &,- 183 &, 158 &,- 089 & $-1,156$ & ,249 \\
\hline & Alínea_A &,- 697 & ,203 &,- 232 & $-3,434$ &, 001 \\
\hline & Alínea_B & $-1,025$ & ,258 &,- 242 & $-3,982$ &, 000 \\
\hline & Alínea_C &,- 397 &, 168 &,- 181 & $-2,365$ & 019 \\
\hline & MaisDeUmAto &,- 542 &, 169 &,- 245 & $-3,205$ & ,002 \\
\hline
\end{tabular}

a. AMOSTRA = Primeira_Amostra

b. Dependent Variable: Porcentagem_MultaArt57_LOG 
Amostra 2.

Model Summary ${ }^{\mathrm{a}}$

\begin{tabular}{|l|r|r|r|r|}
\hline Model & $R$ & $R$ Square & \multicolumn{1}{|c|}{$\begin{array}{c}\text { Adjusted R } \\
\text { Square }\end{array}$} & $\begin{array}{c}\text { Std. Error of the } \\
\text { Estimate }\end{array}$ \\
\hline 1 &, $453^{\mathrm{b}}$ &, 205 &, 184 &, 87972 \\
\hline
\end{tabular}

a. AMOSTRA $=$ Segunda_Amostra

b. Predictors: (Constant), MaisDeUmAto, Montate_Débito,

Ministro_Dummy, Alínea_B, Alínea_A, Político_Dummy, Alínea_C

ANOVA $^{a, b}$

\begin{tabular}{|c|c|c|c|c|c|c|}
\hline \multicolumn{2}{|c|}{ Model } & Sum of Squares & df & Mean Square & $\mathrm{F}$ & Sig. \\
\hline \multirow{3}{*}{1} & Regression & 51,981 & 7 & 7,426 & 9,595 &, $000^{c}$ \\
\hline & Residual & 201,217 & 260 & ,774 & & \\
\hline & Total & 253,197 & 267 & & & \\
\hline
\end{tabular}

a. AMOSTRA = Segunda_Amostra

b. Dependent Variable: Porcentagem_MultaArt57_LOG

c. Predictors: (Constant), MaisDeUmAto, Montate_Débito, Ministro_Dummy, Alínea_B, Alínea_A,

Político_Dummy, Alínea_C

Coefficients ${ }^{a, b}$

\begin{tabular}{|c|c|c|c|c|c|c|}
\hline \multirow{2}{*}{\multicolumn{2}{|c|}{ Model }} & \multicolumn{2}{|c|}{ Unstandardized Coefficients } & \multirow{2}{*}{$\begin{array}{l}\text { Standardized } \\
\text { Coefficients } \\
\text { Beta }\end{array}$} & \multirow[t]{2}{*}{$\mathrm{t}$} & \multirow[t]{2}{*}{ Sig. } \\
\hline & & B & Std. Error & & & \\
\hline \multirow{8}{*}{1} & (Constant) & 2,457 & ,185 & & 13,273 & ,000 \\
\hline & Montate_Débito & $-2,924 \mathrm{E}-007$ &, 000 &,- 427 & $-7,581$ &, 000 \\
\hline & Ministro_Dummy & ,296 & ,161 & ,148 & 1,836 & ,068 \\
\hline & Político_Dummy &,- 099 & ,158 &,- 050 &,- 622 &, 534 \\
\hline & Alínea_A &,- 105 & ,215 &,- 038 &,- 487 & ,627 \\
\hline & Alínea_B &,- 430 & ,267 &,- 108 & $-1,609$ & , 109 \\
\hline & Alínea_C &,- 035 & , 187 &,- 017 &,- 189 & ,850 \\
\hline & MaisDeUmAto &,- 105 & ,184 &,- 052 &,- 572 & ,568 \\
\hline
\end{tabular}

a. $A M O S T R A=$ Segunda_Amostra

b. Dependent Variable: Porcentagem_MultaArt57_LOG 
Amostra total

Model Summary

\begin{tabular}{|l|r|r|r|r|}
\hline Model & \multicolumn{1}{|c|}{$\mathrm{R}$} & R Square & \multicolumn{1}{|c|}{$\begin{array}{c}\text { Adjusted R } \\
\text { Square }\end{array}$} & $\begin{array}{c}\text { Std. Error of the } \\
\text { Estimate }\end{array}$ \\
\hline 1 &, $436^{\mathrm{a}}$ &, 190 &, 180 &, 90775 \\
\hline
\end{tabular}

a. Predictors: (Constant), MaisDeUmAto, Político_Dummy,

Montate_Débito, Alínea_B, Alínea_A, Ministro_Dummy, Alínea_C

ANOVA $^{\mathrm{a}}$

\begin{tabular}{|rl|r|r|r|r|r|}
\hline Model & & Sum of Squares & df & Mean Square & F & Sig. \\
\hline \multirow{2}{*}{1} & Regression & 105,844 & 7 & 15,121 & 18,350 &, $000^{\mathrm{b}}$ \\
& Residual & 450,735 & 547 &, 824 & & \\
& Total & 556,579 & 554 & & & \\
\hline
\end{tabular}

a. Dependent Variable: Porcentagem_MultaArt57_LOG

b. Predictors: (Constant), MaisDeUmAto, Político_Dummy, Montate_Débito, Alínea_B, Alínea_A, Ministro_Dummy, Alínea_C

Coefficients $^{a}$

\begin{tabular}{|c|c|c|c|c|c|c|}
\hline \multirow{2}{*}{\multicolumn{2}{|c|}{ Model }} & \multicolumn{2}{|c|}{ Unstandardized Coefficients } & \multirow{2}{*}{$\begin{array}{l}\text { Standardized } \\
\text { Coefficients } \\
\text { Beta }\end{array}$} & \multirow[t]{2}{*}{$\mathrm{t}$} & \multirow[t]{2}{*}{ Sig. } \\
\hline & & $\mathrm{B}$ & Std. Error & & & \\
\hline \multirow{8}{*}{1} & (Constant) & 2,684 & ,123 & & 21,810 &, 000 \\
\hline & Montate_Débito & $-3,521 \mathrm{E}-007$ & ,000 &,- 386 & $-9,951$ &, 000 \\
\hline & Ministro_Dummy & ,331 & ,116 &, 160 & 2,854 & ,004 \\
\hline & Político_Dummy &,- 153 &, 112 &,- 076 & $-1,373$ & 170 \\
\hline & Alínea_A &,- 455 & ,148 &,- 157 & $-3,085$ & ,002 \\
\hline & Alínea_B &,- 769 & ,186 &,- 187 & $-4,139$ &, 000 \\
\hline & Alínea_C &,- 268 & ,125 &,- 124 & $-2,140$ & ,033 \\
\hline & MaisDeUmAto &,- 369 &, 124 &,- 175 & $-2,970$ & ,003 \\
\hline
\end{tabular}

a. Dependent Variable: Porcentagem_MultaArt57_LOG 


\section{$3^{\circ}$ modelo de regressão: Cargo do gestor.}

\section{Amostra 1.}

\begin{tabular}{|l|r|r|r|r|}
\hline Model & $R$ & $R$ Square & $\begin{array}{c}\text { Adjusted R } \\
\text { Square }\end{array}$ & $\begin{array}{c}\text { Std. Error of the } \\
\text { Estimate }\end{array}$ \\
\hline 1 &, $416^{\mathrm{b}}$ &, 173 &, 157 &, 94767 \\
\hline
\end{tabular}

a. AMOSTRA = Primeira_Amostra

b. Predictors: (Constant), Outros_Cargos, Ministro_Dummy,

Montate_Débito, Presidente_Diretor, Político_Dummy

\section{ANOVA $^{\mathrm{a}, \mathrm{b}}$}

\begin{tabular}{|c|c|c|c|c|c|c|}
\hline \multicolumn{2}{|c|}{ Model } & Sum of Squares & df & Mean Square & $\mathrm{F}$ & Sig. \\
\hline \multirow{3}{*}{1} & Regression & 46,857 & 5 & 9,371 & 10,435 &, $000^{c}$ \\
\hline & Residual & 223,622 & 249 & , 898 & & \\
\hline & Total & 270,479 & 254 & & & \\
\hline
\end{tabular}

a. AMOSTRA $=$ Primeira_Amostra

b. Dependent Variable: Porcentagem_MultaArt57_LOG

c. Predictors: (Constant), Outros_Cargos, Ministro_Dummy, Montate_Débito, Presidente_Diretor, Político_Dummy

\section{Coefficients $^{a, b}$}

\begin{tabular}{|c|c|c|c|c|c|c|}
\hline \multirow{2}{*}{\multicolumn{2}{|c|}{ Model }} & \multicolumn{2}{|c|}{ Unstandardized Coefficients } & \multirow{2}{*}{$\begin{array}{c}\text { Standardized } \\
\text { Coefficients } \\
\text { Beta }\end{array}$} & \multirow[t]{2}{*}{$\mathrm{t}$} & \multirow[t]{2}{*}{ Sig. } \\
\hline & & $\mathrm{B}$ & Std. Error & & & \\
\hline \multirow{6}{*}{1} & (Constant) & 2,301 &, 109 & & 21,081 &, 000 \\
\hline & Montate_Débito & $-5,068 E-007$ &, 000 &,- 346 & $-5,895$ &, 000 \\
\hline & Ministro_Dummy & ,483 &, 176 & ,225 & 2,743 & ,007 \\
\hline & Político_Dummy &,- 287 &, 169 &,- 139 & $-1,692$ & ,092 \\
\hline & Presidente_Diretor &,- 149 &, 162 &,- 055 &,- 921 & ,358 \\
\hline & Outros_Cargos & ,264 &, 155 &, 101 & 1,700 & ,090 \\
\hline
\end{tabular}

a. AMOSTRA $=$ Primeira_Amostra

b. Dependent Variable: Porcentagem_MultaArt57_LOG 
Amostra 2.

Model Summary ${ }^{\mathrm{a}}$

\begin{tabular}{|l|r|r|r|c|}
\hline Model & \multicolumn{1}{|c|}{$\mathrm{R}$} & R Square & \multicolumn{1}{|c|}{$\begin{array}{c}\text { Adjusted R } \\
\text { Square }\end{array}$} & $\begin{array}{c}\text { Std. Error of the } \\
\text { Estimate }\end{array}$ \\
\hline 1 &, $460^{\mathrm{b}}$ &, 211 &, 193 &, 89643 \\
\hline
\end{tabular}

a. AMOSTRA $=$ Segunda_Amostra

b. Predictors: (Constant), Outros_Cargos, Ministro_Dummy, Montate_Débito, Presidente_Diretor, Político_Dummy

ANOVA $^{a, b}$

\begin{tabular}{|c|c|c|c|c|c|c|}
\hline \multicolumn{2}{|c|}{ Model } & Sum of Squares & $d f$ & Mean Square & $\mathrm{F}$ & Sig. \\
\hline \multirow{3}{*}{1} & Regression & 47,783 & 5 & 9,557 & 11,893 &, $000^{c}$ \\
\hline & Residual & 178,396 & 222 & ,804 & & \\
\hline & Total & 226,179 & 227 & & & \\
\hline
\end{tabular}

a. AMOSTRA = Segunda_Amostra

b. Dependent Variable: Porcentagem_MultaArt57_LOG

c. Predictors: (Constant), Outros_Cargos, Ministro_Dummy, Montate_Débito, Presidente_Diretor, Político_Dummy

\section{Coefficients $^{\mathrm{a}, \mathrm{b}}$}

\begin{tabular}{|l|r|r|r|r|r|}
\hline Model & \multicolumn{2}{|c|}{ Unstandardized Coefficients } & \multicolumn{2}{c|}{$\begin{array}{c}\text { Standardized } \\
\text { Coefficients }\end{array}$} & Sig. \\
\cline { 2 - 5 } & B & Std. Error & Beta & \\
\hline & 2,405 &, 110 & & 21,931 &, 000 \\
(Constant) & $-2,804 \mathrm{E}-007$ &, 000 &,- 429 & $-7,166$ &, 000 \\
Montate_Débito &, 268 &, 171 &, 133 & 1,569 &, 118 \\
Ministro_Dummy &,- 024 &, 171 &,- 012 &,- 142 &, 887 \\
Político_Dummy &,- 173 &, 144 &,- 075 & $-1,203$ &, 230 \\
Presidente_Diretor &,- 024 &, 157 &,- 010 &,- 153 &, 878 \\
\hline
\end{tabular}

a. $A M O S T R A=$ Segunda_Amostra

b. Dependent Variable: Porcentagem_MultaArt57_LOG 
Amostra total

Model Summary

\begin{tabular}{|l|r|r|r|r|}
\hline Model & R & R Square & \multicolumn{1}{|c|}{$\begin{array}{c}\text { Adjusted R } \\
\text { Square }\end{array}$} & $\begin{array}{c}\text { Std. Error of the } \\
\text { Estimate }\end{array}$ \\
\hline 1 &, $415^{\mathrm{a}}$ &, 173 &, 164 &, 92839 \\
\hline
\end{tabular}

a. Predictors: (Constant), Outros_Cargos, Ministro_Dummy,

Montate_Débito, Presidente_Diretor, Político_Dummy

\section{ANOVA $^{\mathrm{a}}$}

\begin{tabular}{|c|c|c|c|c|c|c|}
\hline \multicolumn{2}{|c|}{ Model } & Sum of Squares & df & Mean Square & $\mathrm{F}$ & Sig. \\
\hline \multirow{3}{*}{1} & Regression & 85,764 & 5 & 17,153 & 19,901 &, $000^{b}$ \\
\hline & Residual & 411,134 & 477 & ,862 & & \\
\hline & Total & 496,898 & 482 & & & \\
\hline
\end{tabular}

a. Dependent Variable: Porcentagem_MultaArt57_LOG

b. Predictors: (Constant), Outros_Cargos, Ministro_Dummy, Montate_Débito, Presidente_Diretor, Político_Dummy

\section{Coefficients $^{\mathrm{a}}$}

\begin{tabular}{|l|r|r|r|r|r|}
\hline Model & \multicolumn{2}{|c|}{ Unstandardized Coefficients } & \multicolumn{2}{c|}{$\begin{array}{c}\text { Standardized } \\
\text { Coefficients }\end{array}$} & Sig. \\
\cline { 2 - 5 } & B & Std. Error & Beta & \\
\hline (Constant) & 2,333 &, 077 & 30,183 &, 000 \\
Montate_Débito & $-3,197 \mathrm{E}-007$ &, 000 &,- 367 & $-8,772$ &, 000 \\
Ministro_Dummy &, 387 &, 123 &, 186 & 3,135 &, 002 \\
Político_Dummy &,,- 167 &, 121 &,- 082 & $-1,381$ &, 168 \\
Presidente_Diretor &,- 170 &, 108 &,- 068 & $-1,583$ &, 114 \\
Outros_Cargos &, 108 &, 110 &, 042 &, 980 &, 328 \\
\hline
\end{tabular}

a. Dependent Variable: Porcentagem_MultaArt57_LOG 